\title{
Long-Lived Activation Products in Reactor Materials
}

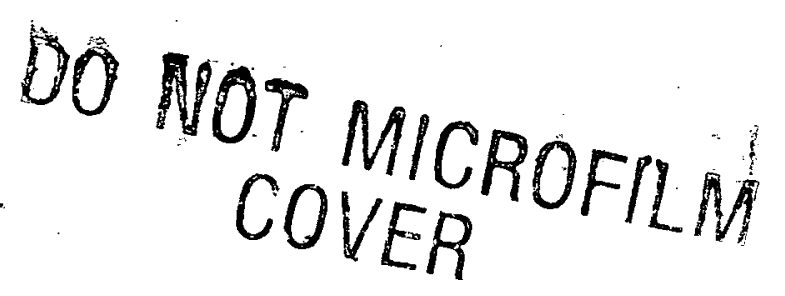

Prepared by J. C. Evans, E. L. Lepel, R. W. Sanders, C. L. Wilkerson, W. Silker, C. W. Thomas, K. H. Abel, D. R. Robertson

Pacific Northwest Laboratory

Operated by

Battelle Memorial Institute

Prepared for

U.S. Nuclear Regulatory

Commission 


\section{DISCLAIMER}

This report was prepared as an account of work sponsored by an agency of the United States Government. Neither the United States Government nor any agency Thereof, nor any of their employees, makes any warranty, express or implied, or assumes any legal liability or responsibility for the accuracy, completeness, or usefulness of any information, apparatus, product, or process disclosed, or represents that its use would not infringe privately owned rights. Reference herein to any specific commercial product, process, or service by trade name, trademark, manufacturer, or otherwise does not necessarily constitute or imply its endorsement, recommendation, or favoring by the United States Government or any agency thereof. The views and opinions of authors expressed herein do not necessarily state or reflect those of the United States Government or any agency thereof. 


\section{DISCLAIMER}

Portions of this document may be illegible in electronic image products. Images are produced from the best available original document. 


\section{NOTICE}

This report was prepared as an account of work sponsored by an agency of the United States Government. Neither the United States Government nor any agency thereof, or any of their employees, makes any warranty. expressed or implied, or assumes any legal liability of responsibility for any third party's use, or the results of such use, of any information, apparatus, product or process disclosed in this report, or represents that its use by such third party would not infringe privately owned rights.

\section{NOTICE}

\section{Availability of Reference Materials Cited in NRC Publications}

Most documents cited in NRC publications will be available from one of the following sources:

1. The NRC Public Document Room, 1717 H Street, N.W. Washington, DC 20555

2. The NRC/GPO Sales Program, U.S. Nuclear Regulatory Commission, Washington, DC 20555

3. The National Technical Information Service, Springfield, VA 22161

Although the listing that follows represents the majority of documents cited in NRC publications, it is not intended to be exhaustive.

Referenced documents available for inspection and copying for a fee from the NRC Public Document Room include NRC correspondence and internal NRC memoranda; NRC Office of Inspection and Enforcement bulletins, circulars, information notices, inspection and investigation notices; Licensee Event Reports; vendor reports and correspondence; Commission papers; and applicant and licensee documents and correspondence.

The following documents in the NUREG series are available for purchase from the NRC/GPO Sales Program: formal NRC staff and contractor reports, NRC-sponsored conference proceedings, and NRC booklets and brochures. Also available are Regulatory Guides, NRC regulations in the Code of Federal Regulations, and Nuclear Regulatory Commission Issuances.

Documents available from the National Technical Information Service include NUREG series reports and technical reports prepared by other federal agencies and reports prepared by the Atomic Energy Commission, forerunner agency to the Nuclear Regulatory Commission.

Documents available from public and special technical libraries include all open literature items, such as books, journal and periodical articles, and transactions. Federal Register notices, federal and state legislation, and congressional reports can usually be obtained from these libraries.

Documents such as theses, dissertations, foreign reports and translations, and non-NRC conference proceedings are available for purchase from the organization sponsoring the publication cited.

Single copies of NRC draft reports are available free, to the extent of supply, upon written request to the Divișion of Technical Information and Document Control, U.S. Nuclear Regulatory Commission, Washington, DC 20555.

Copjes of industry codes and standards used in a substantive manner in the NRC regulatory process are maintatined at tite: NRC Library, 7920 Norfolk Avenue, Bethesda, Maryland, and are available there for Peference use by the public. Codes and standards are usually copyrighted and may be purchased from the originating organization or, if they are American National Standards, from the American National Standards Institute, 1430 Broadway, New York, NY 10018. 


\section{Long-Lived Activation Products in Reactor Materials}

Manuscript Completed: July 1984

Date Published: August 1984

Prepared by

J. C. Evans, E. L. Lepel, R. W. Sanders, C. L. Wilkerson,

W. Silker, C. W. Thomas, K. H. Abel, D. R. Robertson

Pacific Northwest Laboratory

Richland, WA 99352

\section{Prepared for}

Division of Engineering Technology

Office of Nuclear Regulatory Research

U.S. Nuclear Regulatory Commission

Washington, D.C. 20555

NRC FIN B2296

\section{MOTICE}

PQRTIONS OF THIS REPORT ARE ILLEGIALE. It has been reproduced from the hest available copp to permit the broadest possible avallability.

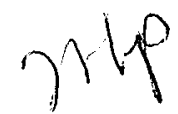




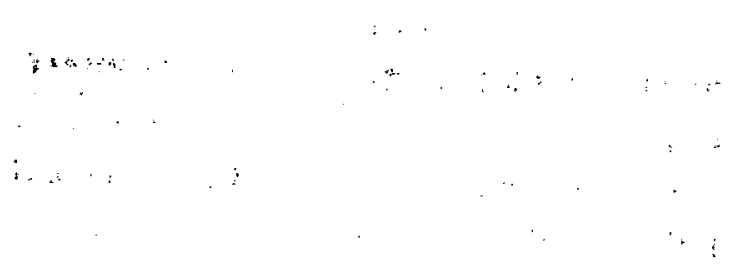


The purpose of this program was to assess the problems posed to reactor decommissioning by long-lived activation products in reactor construction materials. Samples of stainless steel, vessel steel, concrete, and concrete ingredients were analyzed for up to 52 elements in order to develop a data base of activatable major, minor, and trace elements. Large compositional variations were noted for some elements. Cobalt and niobium concentrations in stainless steel, for example, were found to vary by more than an order of magnitude. A thorough evaluation was made of all possible nuclear reactions that could lead to long lived activation products. It was concluded that all major activation products have been satisfactorily accounted for in decommissioning planning studies completed to date. A detailed series of calculations was carried out using average values of the measured compositions of the appropriate materials to predict the levels of activation products expected in reactor internals, vessel walls, and bioshield materials for PWR and BWR geometries. A comparison is made between calculated activation levels and regulatory guidelines for shallow land disposal according to 10 CFR 61. This analysis shows that PWR and BWR shroud material exceeds the class C limits and is, therefore, generally unsuitable for near-surface disposal. The PWR core barrel material approaches the Class $C$ limits. Most of the remaining massive components qualify as either Class $A$ or $B$ waste with the bioshield clearly Class $A$, even at the highest point of activation. Selected samples of activated steel and concrete were subjected to a limited radiochemical analysis program as a verification of the computer model. Reasonably good agreement with the calculations was obtained where comparison was possible. In particular, the presence of ${ }^{94} \mathrm{Nb}$ in activated stainless steel at or somewhat above expected levels was confirmed. 


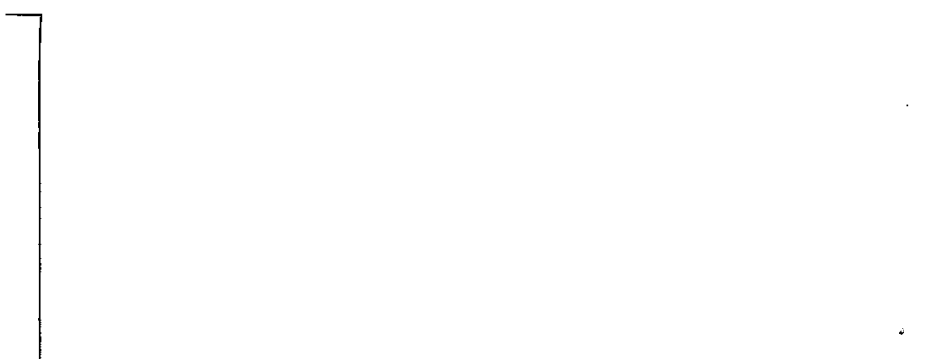

$=$

.

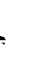
' 


\section{CONTENTS}

ABSTRACT

EXECUTIVE SUMMARY

1.0 INTRODUCTION..................................... 5

1.1 REVIEW OF PROPOSED DECOMMISSIONING STRATEGIES............ 5

1.2 LONG-LIVED ACTIVATION PRODUCTS.................... 7

1.2.1 Scope of Problem........................... 7

1.2.2 Review of Existing Information................ 8

1.2.3 Description of Research Program................ 12

2.0 REVIEW OF NUCLEAR PROPERTIES ....................... 15

2.1 ACTIVATION REACTIONS .......................... 15

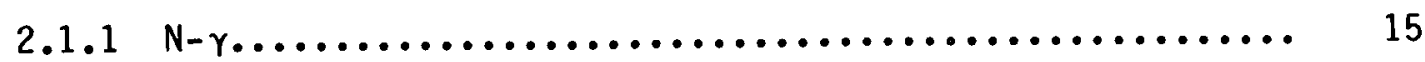

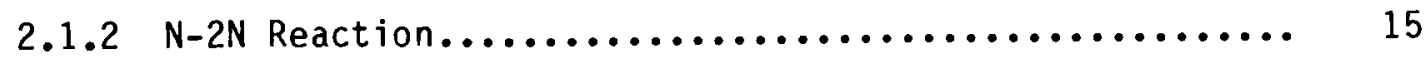

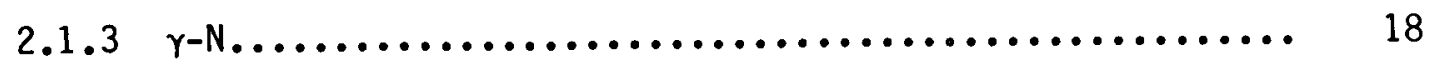

2.1.4 $\mathrm{N}-\mathrm{X}$ (Charged Particle Reactions)................. 19

2.1.5 $N, N^{1}, \gamma-\gamma^{1}$ (Inelastic Scattering)................ 19

$2.1 .6 \mathrm{~N}-\mathrm{F}$ (Neutron Induced Fission)................. 20

2.2 ISOTOPE PROPERTIES ............................ 21

2.2.1 Gamma Emitters............................ 21

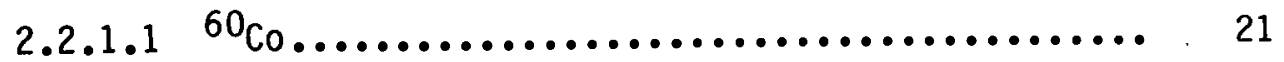

$2.2 .1 .2 \quad 152,154_{E u} \ldots \ldots \ldots \ldots \ldots \ldots \ldots \ldots \ldots \ldots \ldots \ldots \ldots . . \ldots . \ldots \ldots$

$2.2 .1 .3^{94}{ }^{N b} \ldots \ldots \ldots \ldots \ldots \ldots \ldots \ldots \ldots \ldots \ldots \ldots \ldots \ldots . \ldots \ldots$

$2.2 .1 .4 \quad 108 m_{A g} \ldots \ldots \ldots \ldots \ldots \ldots \ldots \ldots \ldots \ldots \ldots \ldots \ldots \ldots . \ldots \ldots$

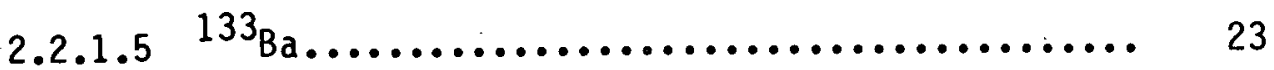

2.2.1.6 Other Gamma Emitters................. 23 
2.2.2 Pure Beta Emitters.......................... 23

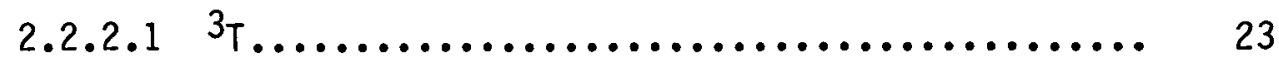

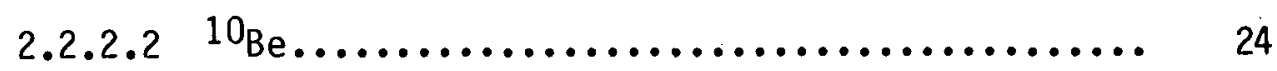

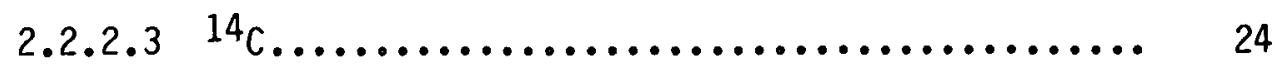

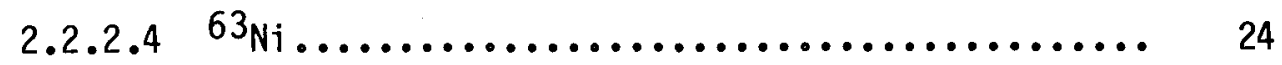

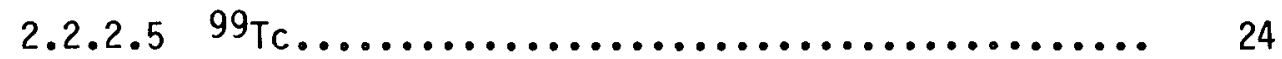

2.2.2.6 Other Beta Emitters.................. 25

2.2.3 Electron Capture Isotopes..................... 25

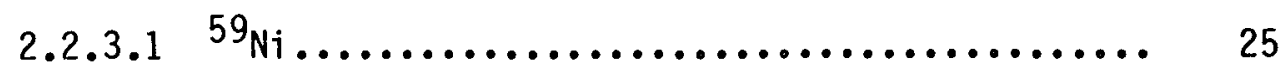

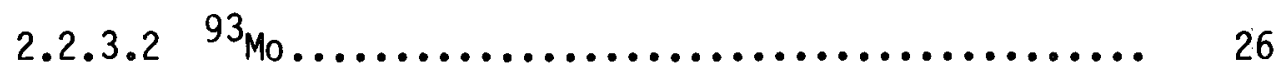

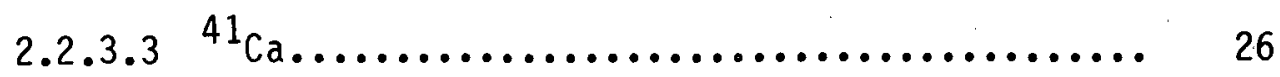

2.2.3.4 Other Electron Capture Isotopes............ 27

2.2.4 Alpha Emitters............................ 27

3.0 CONSTRUCTION MATERIALS................................. 29

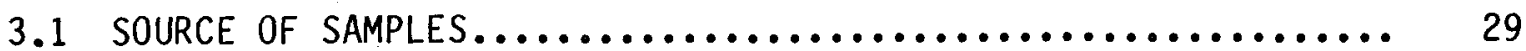

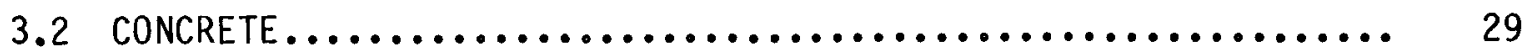

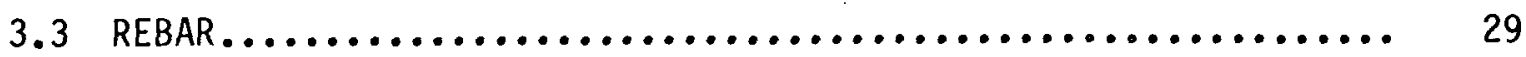

3.4 CARBON STEEL.................................. 30

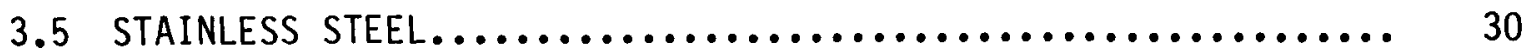

3.6 CONTROL RODS $. . \ldots \ldots \ldots \ldots \ldots \ldots \ldots \ldots \ldots \ldots \ldots \ldots \ldots \ldots \ldots \ldots \ldots \ldots \ldots, 31$

4.0 CHEMical ANAlysis PROGRAM.............................. 33

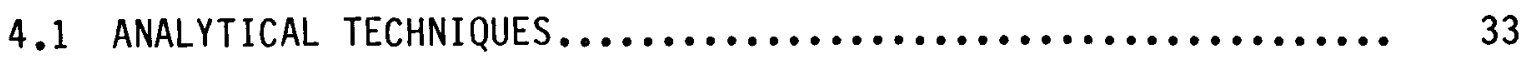

4.1.1 Instrumental Neutron Activation Analysis (INAA)...... 33

4.1.2 X-ray Fluorescence Analys is (XRF) $\ldots \ldots \ldots \ldots \ldots \ldots . . . . . .38$

4.1.3 Other Analytical Methods Used.................. 42 
4.2 CHEMICAL ANALYSIS RESULTS $\ldots \ldots \ldots \ldots \ldots \ldots \ldots \ldots \ldots \ldots \ldots \ldots, 43$

4.2.1 Stainless Steel............................ 43

4.2.2 Other Reactor Internals Steels................. 43

4.2 .3 Vessel Steels............................... 43

4.2.4 Rebar...................................... 49

4.2 .5 Concrete................................... 49

4.2.6 Concrete Ingredients......................... 54

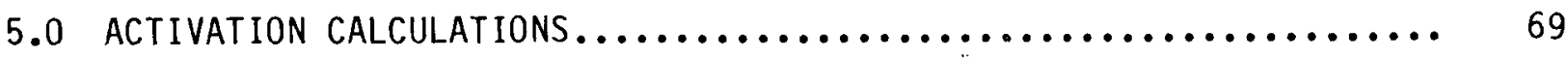

5.1 CALCULATION METHOD................................ 69

5.2 CROSS-SECTION SELECTION........................... 71

5.2.1 $\mathrm{N}-\gamma$-Thermal.............................. 71

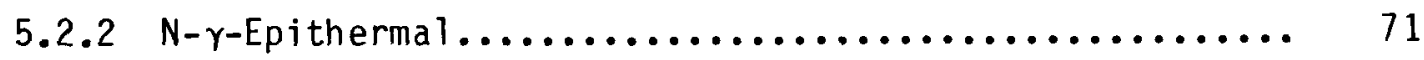

5.2.3 Fast Neutron Reactions...................... 72

5.3 NEUTRON FLUX INFORMATION.......................... 72

5.4 RESULTS OF ACTIVATION CALCULATIONS.................. 72

5.4 .1 Internals.............................. 77

5.4 .2 Pressure Vessel Wall......................... 85

5.4.3 Bioshield Concrete............................ 85

5.4 .5 Rebar..................................... 85

5.4.6 Regulatory Considerations for Waste Disposal........ 97

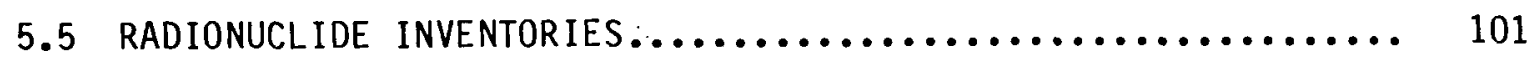

6.0 RADIOCHEMICAL ANALYSIS PROGRAM........................ 109

6.1 SAMPLES ANALYZED............................... 109

6.1 .1 Steels................................. 109

6.1 .2 Concretes.............................. 110 


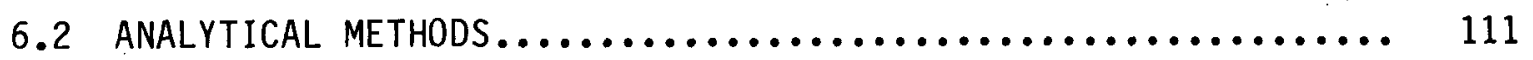

6.2.1 Nondestructive Gamma Assay..................... 111

6.2.2 Radiochemical Separation Procedures and Counting...... 111

6.2.2.1 ${ }^{55_{\mathrm{Fe}}}$ Determination................... 111

6.2.2.2 ${ }^{63} \mathrm{Ni}$ and ${ }^{59} \mathrm{Ni}$ Determination.............. 112

6.2.2.3 ${ }^{93}$ Mo Determination.................... 112

6.2.2.4 ${ }^{94} \mathrm{Nb}$ Determination.................... 112

6.2.2.5 ${ }^{99} T c$ Determination..................... 112

6.2.2.6 Europium Isotopes................... 112

6.3 RADIOCHEMICAL ANALYSIS RESULTS...................... 113

6.3 .1 Steels.................................... 113

6.3 .2 Concretes............................... 116

6.3 .3 Conclusions $. . \ldots \ldots \ldots \ldots \ldots \ldots \ldots \ldots \ldots \ldots \ldots \ldots \ldots, 119$

7.0 EFFECT ON DECOMMMISSIONING STRATEgIES $\ldots \ldots \ldots \ldots \ldots \ldots \ldots \ldots \ldots . \ldots \ldots \ldots$

8.0 RECOMMENDATIONS FOR FUTURE STUDIES $\ldots \ldots \ldots \ldots \ldots \ldots \ldots \ldots \ldots \ldots \ldots \ldots \ldots \ldots$

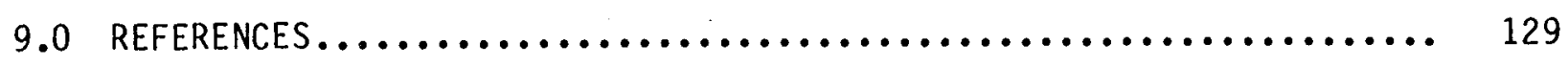

APPENDIX A - CODE DESCRIPTION............................ A.1

APPENDIX B - PROGRAM LISTINGS........................... B. 1 
FIGURES

2.1 Representative Neutron Capture Cross-Sections for

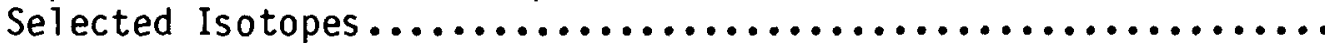

2.2 Relative Contribution of Resonance Capture for

Selected Isotopes.

4.1a Averaged Elemental Concentrations in Bioshield Concrete

Normalized to Average Crustal Abundance.................... 55

4.2a Weighted Fit of Three Components to Concentration of

32 Elements for Hartsville Bioshield Concrete ............... 65

4.3a Contribution of Fly Ash to Elemental Concentration

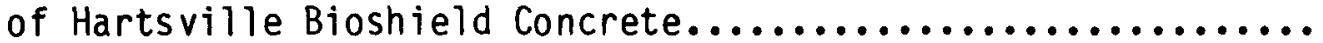

5.1 Radial Three Group Neutron Flux Distribution at Core Axial

Midplane, ANISN Calculation for Westinghouse PWR.

5.2 Cadmium Ratio Radial Distribution at Core Axial Midplane,

ANISN Calculation for Westinghouse PWR.

5.3 Radial Three Group Neutron Flux Distribution at Core

Axial Midplane, ANISN Calculation GE BWR.................. 75

5.4 Cadmium Ratio Radial Distribution at Core Axial

Midplane, ANISN Calculation for GE BWR................ 76

5.5 Activation of PWR Shroud Type 304 Stainless Steel 30 EFPY...... 79

5.6 PWR Shroud Type 304 Stainless Steel 30 EFPY............... 80

5.7 Activation of PWR Core Barrel Type 304 Stainless Steel

30 EFPY.

5.8 Activation of PWR Thermal Pads Type 304 Stainless Steel

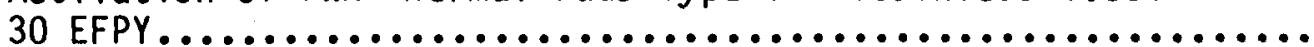

5.9 Activation of PWR Vessel Cladding Type 304 Stainless Stee 1

30 EFPY......................................... 83

5.10 PWR Vessel Wall 30 EFPY - Decommissioning Time Scale......... 87

5.11 PWR Vessel Wall 30 EFPY - Long Term Disposal Time Scale....... 88

5.12 PWR Bioshield Average Concrete - $10 \mathrm{~cm}$ Depth 30 EFPY -

Decommissioning Time Scale.. 
5.13 PWR Bioshield Average Concrete - $10 \mathrm{~cm}$ Depth 30 EFPY Long Term Disposal Time Scale.........................

5.14 PWR Bioshield Rebar - $10 \mathrm{~cm}$ Depth 30 EFPY - Decommissioning

Time Scale...................................... 94

5.16 PWR Bioshield Average Concrete Activity Versus Depth 30 EFPY Operation................................ 107

6.1 Depth Profile of Radionuclides in Concrete Core Taken from Sump Floor at Pathfinder.

6.2 Depth Profile of Radionuclides in Concrete Core Taken from Sump Floor at Turkey Point No. 4..................... 122 


\section{TABLES}

$1.1 \quad$ Long-Lived Activation Products with Half-Lives

Greater than 5 Years................................ 9

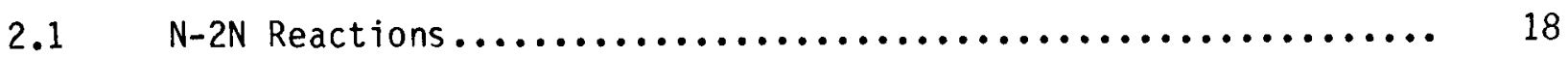

2.2 Activation Reactions Involving Charged Particles........... 20

$3.1 \quad$ Bioshield Materials............................. 30

3.2 Steel Samples................................ 31

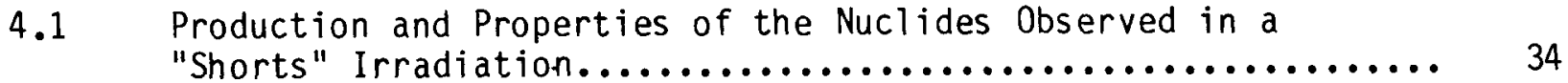

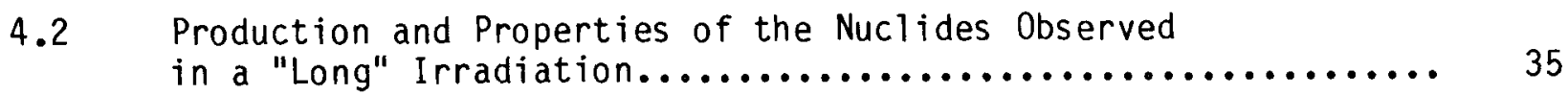

4.3 Comparison of Experimental and Reported Standard Values for "Shorts" Analys is.............................. 39

4.4 Comparison of Experimental and Reported Standard Values for "Longs" Analysis................................ 40

4.5 Comparison of Experimental and Reported Values for XRF

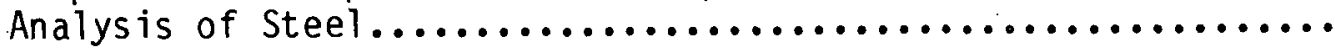

4.6 Comparison of Experimental and Reported Values for XRF Analys is of Fly Ash......................... 42

4.7 Chemical Analyses of Type 304 Stainless Steel.............. 44

4.8 Type 304 Stainless Steel Composition Summary.............. 45

4.9 Chemical Analys is of Steel Used for Reactor Internals ........ 46

4.10 Chemical Analys is of Vessel Steels..................... 47

4.11 Vessel Steels Composition Summary..................... 48

4.12 Chemical Analysis of Rebar........................ 50

4.13 Rebar Composition Summary.......................... 51

4.14 Chemical Analys is "of Bioshield Concrete................. 52

4.15 Bioshield Concrete Composition Summary................. 53 
4.16 Cobalt to Europium Ratio in Bioshield Concrete............... 54

4.17 Chemical Analysis of Cement Used for Bioshield Concrete....... 57

4.18 Chemical Analys is of Coarse Aggregate for Bioshield Concrete... 58

4.19 Chemical Analysis of Sand Aggregate for Bioshield Concrete.... 59

4.20 Chemical Analysis of Fly Ash Used in Bioshield Concrete....... 60

4.21 Concrete Ingredients (Palo Verde) Elemental Concentrations..... 61

4.22 Concrete Ingredients (Enrico Fermi) Elemental Concentrations... 62

4.23 Concrete Ingredients (Hartsville) Elemental Concentrations..... 63

4.24 Weighted Least Squares Fit to Concentrations of Elements in Hartsville Bioshield Concrete........................... 64

5.1 Activation of PWR Internals Type 304L Stainless Steel 30 EFPY at Core Axial Midplane............................ 78

5.2 Activation of BWR Internals (Ci/gm) Type 304L Stainless Steel 30 EFPY at Core Axial Midplane...................... 84

5.3 Activation of Pressure Vessel Walls 30 EFPY at Core Axial Midplane...................................... $\quad{ }_{86}$

5.4 Activation of PWR Bioshield Average Concrete 30 EFPY at Core Axial Midplane....................................

5.5 Activation of BWR Bioshield Average Concrete 30 EFPY at Core Axial Midplane.................................. 92

5.6 Activation of PWR Bioshield Average Rebar 30 EFPY at Core Axial Midplane....................................

5.7 Activation of BWR Bioshield Average Rebar 30 EFPY at Core Axial Midplane......................................

5.8 Comparison of Rebar Versus Concrete Matrix of PWR Bioshield $30 \mathrm{EFPY}$ at Core Axial Midplane $10 \mathrm{~cm}$ Deep...................

5.9 Classification of PWR Intervals for Low Level Waste Disposal - Core Axial Midplane - 30 EFPY, Activity

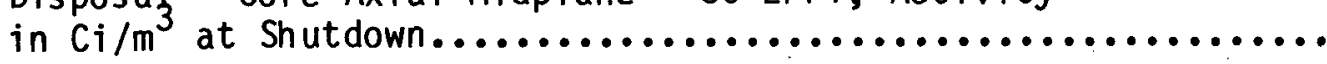

5.10 Classification of BWR Intervals for Low Level Waste Disposal - Core Axial Midplane - 30 EFPY, Activity in $\mathrm{C} i / \mathrm{m}^{3}$ at Shutdown 
5.11 Classification of Bioshield Concrete for Low Level

Waste Disposal - Core Axial Midplane - 30 EFPY,

$10 \mathrm{~cm}$ Depth Activity in $\mathrm{Ci} / \mathrm{m}^{3}$ at Shutdown................ 101

5.12 Parameters Used for Radionuclide Inventory................ 102

5.13 Activity Inventory of PWR Internals at Shutdown............. 103

5.14 Activity Inventory of BWR Internals at Shutdown............. 104

5.15 Activity Inventories of PWR and BWR Vessel Walls at Shutdown... 105

5.16 Activity Inventory Summary....................... 106

6.1 Irradiated Stainless Steel - Measured Versus

Calculated Activity in $\mu \mathrm{Ci} / \mathrm{gm} . \ldots \ldots \ldots \ldots \ldots \ldots \ldots \ldots \ldots \ldots . \ldots \ldots$

6.2 Irradiated Vessel Steels - Measured Versus Calculated

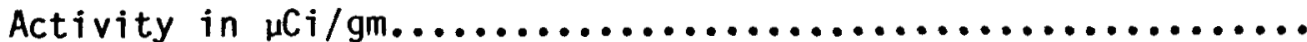

6.3 Pathfinder Concrete Core PCC-8 Directly Beneath

Vessel Activity in $\mathrm{pCi} / \mathrm{gm}$ Corrected to Shutdown

and 30 EFPY.

6.4 Pathfinder Concrete Core PCC-8 Comparison of Measured

and Calculated Activities.

6.5 Humboldt Bay Concrete Bioshield Samples Activity at

Shutdown and 30 EFPY.

6.6 Humboldt Bay Concrete from Upper Shield Ring HBRS-25

Comparison of Measured and Calculated Activities.

6.7 Turkey Point Unit 4 Concrete Core Taken Directly Beneath

Vessel Activity at Shutdown and 30 EFPY.

6.8 Turkey Point Unit 4 Concrete Core Taken Directly Beneath

Vessel Activity at Shutdown and 30 EFPY.

6.9 Turkey Point Unit 4 Concrete Core TP-I Comparison of Measured and Calculated Activities. 


\section{NOTICE}

This report was prepared as an account of work sponsored by an agency of the United States Government. Neither the United States Government nor any agency thereof, or any of their employees, makes any warranty, expressed or implied, or assumes any legal liability of re. sponsibitity for any third party's use, or the results of such use, of any information, apparatus, product or process disclosed in this report, or represents that its use by such third party would not infringe privately owned rights.

\section{Availability of Reference Materials Cited in NRC Publications}

Most documents cited in NRC publications will be available from one of the following sources:

1. The NRC Public Document Room, 1717 H Street, N.W. Washington, DC 20555

2. The NRC/GPO Sales Program, U.S. Nuclear Regulatory Commission, Washington, DC 20555

3. The National Technical Information Service, Springfield,. VA 22161

Although the listing that follows represents the majority of documents cited in NRC publications, it is not intended to be exhaustive.

Referenced documents available for inspection and copying for a fee from the NRC'Public Document Room include NRC correspondence and irternal NRC memoranda; NRC Office of Inspection and Enforcement bulletins, circulars, information notices, inspection and investigation notices; Licensee Event Reports; vendor reports and correspondence; Commission papers; and applicant and licensee documents and correspondence.

The following documents in the NUREG series are available for purchase from the NRC/GPO Sales Program: formal NRC staff and contractor reports, NRC-sponsored conference proceedings, and NRC booklets and brochures. Also available are Regulatory Guides, NRC regulations in the Code of Federal Regulations, and Nuclear Regulatory Commission Issuances.

Documents available from the National Technical Information Service include NUREG series reports and technical reports prepared by other federal agencies and reports prepared by the Atomic Energy Commission, forerunner agency to the Nuclear Regulatory Commission.

Documents available from public and special technical libraries include all open literature items, such as books, journal and periodical articles, and transactions. Federal Register notices, federal and state legislation, and congressional reports can usually be obtained from these libraries.

Documents such as theses, dissertations, foreign reports and translations, and non-NRC conference proceedings are available for purchase from the organization sponsoring the publication cited.

Single copies of NRC draft reports are available free upon written request to the Division of Tech. nical Information and Document Control, U.S. Nuclear Regulatory Commission. Washington, DC 20555.

Copies of industry codes and standards used in a substantive manner in the NRC regulatory process are maintained at the NRC Library. 7920 Norfolk Avenue. Bethesda, Maryland, and are available there for reference use by the public. Codes and standards are usually copyrighted and may be purchased from the originating organization or, if they are American National Standards, from the American National Standards Institute. 1430 Broadway. New York. NY 10018. 
This report presents the results of a three-phase project that was designed to assess the potential problems posed to light water reactor (LWR) decommissioning by long-lived activation products produced in the major construction materials of the reactor. Reactor components investigated included the bioshield, pressure vessel, vessel cladding, and stainless steel internals.

In the first phase of the study, samples were solicited from all utilities in the United States with reactors under construction, and a large number of appropriate samples were obtained. A few samples were obtained from operating and shutdown reactors, also. Samples were analyzed for up to 52 elements by a combination of analytical techniques including instrumental neutron activation analysis, energy dispersive $X$-ray fluorescence analysis, and a number of special single element techniques. The stainless steel samples analyzed showed little variability in their major element composition, but varied widely in the content of activatable trace elements, notably cobalt and niobium, both of which showed concentration ranges of more than a factor of 10 . Selenium, bromine, and molybdenum also showed very wide variability, but are not present in sufficient quantities to result in the production of significant levels of activation products. The vessels' steels showed no unusual compositional features. Niobium levels were, in general, much lower than in the stainless steel samples. The long-lived activation inventory should be dominated primarily by activation of iron, cobalt, and nickel. With the exception of niobium, trace elements are of negligible importance at the concentration levels found.

A wide range of compositional variation was seen in the concrete samples studied, reflecting geologic differences in the quarry sites used for the aggregate. The composition of the concrete samples studied was, on the average, very similar to that of typical crustal rock for most elements of interest. A few of the reactor sites sampled used fly ash in small amounts (4\%) as a concrete additive. While this did increase the concentration of some trace elements up a factor of 2 or more, it does not appear to represent any significant problem with respect to the inventory of long-lived radionuclides. The 48 rebar samples studied showed a relatively constant composition typical of carbon steel. The rebar component dominates the bioshield composition for nickel and adds significant amounts of iron, cobalt, "and molybdenum. The inventory of other elements was completely dominated by the concrete itself with the rebar of negligible importance.

The second phase of the study consisted of the calculation of expected levels of long-lived activation 'products in the major reactor components for various time scales. A thorough evaluation was made of all possible activation 
products that could be produced in sensible quantities in a LWR. Fifty-two isotopes with half-lives greater 5 five years were considered. It was concluded, that with a few exceptions the activation inventory is overwhelmingly dominated by thermal neutron capture with $N-P$ and $N-\alpha$ reactions of importance only. for ${ }^{54} \mathrm{Mn},{ }^{14} \mathrm{C}$, and ${ }^{3} \mathrm{~T}$ production. Photonuclear reactions are of negligible importance. A thorough review of all available cross-section information was carried out for both slow and fast neutron reactions. This information was incorporated into a multigroup computer code specifically written for that purpose. The code was used to calculate expected levels of activation products in reactor internals, vessel cladding, vessel walls; and at various depths in the bioshields. Average materials compositions taken from the first phase of the study were used in the calculations. A series of calculations was carried out for both pressure water reactor (PWR) and boiling water reactor (BWR) geometries. The majority of the activation product's inventory of the reactor was found to reside in the core shroud with only a few isotopes dominating the total activity levels. Cobalt-60 was found to dominate the total activity from 5 years to about 20 years; it dominated the gamma dose for up to 100 years. After 100 years, ${ }^{94} \mathrm{Nb}$ will be the dominant gamma emitter with ${ }_{5}$ minor contribution, because of its small inner bremsstrahlung branch, from ${ }^{59} \mathrm{Ni}$. The nickel isotopes dominate the total activity after about 20 years. A similar pattern is seen in the vessel wall itself but with a somewhat diminished importance for $\mathrm{Co}$ and $\mathrm{Ni}$. Activation levels in the vessel wall and vessel cladding were found to be reduced by a factor of 15 for the BWR geometry. The activation patterns for the bioshield concrete was, of course, quite different with a much more complex mix of isotopes possible. On the 100-year time scale, the total activity of concrete is dominated by tritium, while on the long-term disposal time scale of hundreds to thousands of years the total activity is totally dominated by ${ }^{41} \mathrm{Ca}$ representing about $99 \%$ of the total activity. Maximum activation levels for ${ }^{41} \mathrm{Ca}$ do not appear to represent any serious hazard potential, however. Gamma activity from the bioshield is mainly due to ${ }^{152}$ Eu with ${ }^{60} \mathrm{Co}$ of relatively minor importance after the first 20 years. Rebar was found to be a minor contributor to the bioshield activation inventory. For a $10 \%$ rebar component, the ${ }^{60} \mathrm{Co}$ contributions from the rebar and concrete are approximately equal. A comparison was made between calculated activation levels at various points in PWR and BWR systems and the regulatory guidelines stated in 10 CFR 61 for shallow land disposal of that material following decommissioning. Using those specifications, in general, ${ }^{63} \mathrm{Ni}$ levels become the dominant consideration. On that basis, the PWR shroud exceeds the Class $C$ limits for near-surface disposal while the core barrel approaches these limits. A similar situation exists for the BWR shroud. Control rods are difficult to model and will require a separate detailed study. 'At least from a direct activation standpoint, the remaining massive components will qualify as Class $A$ or $B$ waste. Some surface decontamination may be required to remove other sources of activity, however. Activity inventories for the total reactor system were calculated for shutdown after 30 EFPY of operation. For the PWR case, the 
total was 1.7 million curies of isotopes with half lives greater than 5 years with only $1700 \mathrm{Ci}$ in the bioshield. For the BWR case, 530,000 Ci were estimated for the reactor internals with $146 \mathrm{Ci}$ in the bioshield. The results of this work are fully consistent with a number of previous studies. It appears that all significant activation products have been satisfactorily considered in the decomissioning strategies currently under consideration.

The third phase of the work consisted of a radiochemical analysis of neutron activated samples of steel and concrete. This was intended as a check on the calculation method.

Within the framework of the samples available, only a limited verification of the predictive capability was possible. In the steel samples, ${ }^{59} \mathrm{Ni}, 6{ }^{3} \mathrm{Ni}$, and 93 Mo were found to be present at approximately the expected levels based on a neutron flux normalization using the measured ${ }^{55} \mathrm{Fe}$ levels to adjust the predictions. The presence of ${ }^{94} \mathrm{Nb}$ in stainless steel samples was verified, and its measured levels were somewhat higher than expected. The discrepancy appears to be attributable to epithermal capture in the core region for those particular samples. For the concrete samples, the dominant role of the europium isotopes was verified with good agreement between measurement and calculation obtained for a number of shorter-lived isotopes. It was not possible to determine ${ }^{41} \mathrm{Ca}$ activation in the rather low-level samples used in this study. 
$$
\text { . }
$$ 


\subsection{INTRODUCTION}

This report presents the results of a study sponsored by the U.S. Nuclear Regulatory Commission (NRC) to investigate the problems posed to eventual decommissioning of light water reactors (LWR) by nuclear activation of major reactor construction materials to isotopes with half-lives of importance on the time scale for decommissioning and disposal. This information is of importance in the design of decommissioning strategies and in the formulation of regulatory guidelines for implementing those strategies. The program is divided into three major tasks. The first task consists of the assessing of the levels of major, minor, and trace elements in the major construction materials used in pressure water reactor (PWR) and boiling water reactor (BWR) construction. These materials consist primarily of concrete (cement, fly ash, sand and aggregate), rebar, vessel steel and stainless steel internals. Samples of these materials were solicited from all utilities in the United States with reactors under construction, as well as from a number of operating reactor sites. A comprehensive program of chemical analysis was carried out on these samples for up to 52 elements. The second task consists of estimating expected levels of activation products produced in materials of representative composition as defined by the chemical analysis work. A thorough assessment was made of all potentially important nuclear activation pathways for more than 40 isotopes with half-lives ranging from a few years to tens of millions of years for incorporation into a computer model so that no important activation product would be overlooked. Finally, samples of activated material were obtained from several operating or decommissioned reactors and were subjected to radiochemical assay for selected long-lived isotopes.

\subsection{REVIEW OF PROPOSED DECOMMISSIONING STRATEGIES}

According to a recent U.S. Department of Energy (DOE) survey (U.S. DOE 1981) there are now a total of 75 central station electric power reactors operating in the United States with an additional 81 under construction. Although that number is now reduced due to project terminations, it is still large. The operating life span of these reactors is estimated to be of order of 40 years. These reactors will, at some time in the future, represent a problem with regard to the ultimate disposition of the massive components of the reactor station. This problem is complicated by the presence of substantial amounts of activation products formed over the life of the reactor. These activation products begin decaying immediately upon shutdown and have a wide range of half lives. The type of problem caused by specific isotopes is to a large extent a function of the particular decommissioning strategy chosen. According to Smith, Konzek and Kennedy (1978) "...decommissioning is defined, for a nuclear facility, as the measures taken at the end of the facility's 
operating life to assure the continued protection of the public from any residual radioactivity or other potential hazards present in the facility." Several basic approaches have been considered. The first approach involves immediate dismantlement over a 4-year period, shortly after final cessation of power production operations. This was basically the approach used in the Elk River decommissioning, and more recently, in the Sodium Reactor experiment. A number of decommissioning projects currently being initiated have also opted for immediate dismantlement. Examples include the British Windscale Advanced Gas-Cooled Reactor and the Japanese JPDR, as well as the Shippingport station, which will be the largest such project attempted to date. A significant advantage of this procedure is the continuity on site of staff familiar with all aspects of the reactor operation. An alternative to the first approach is some type of safe storage with a deferred dismantlement. The deferrment would typically be of the order of 30 to 50 years. The principal purpose of the deferral period is to allow decay of residual radioactivity to more manageable levels. The first option may, in fact, be more cost effective, while the second offers reduced risk of exposure to both the decommissioning workers and the public. The goal of both of these options is the removal of a potential long-term hazard from the immediate environs and, ideally, the return of the land to unrestricted use. The remaining option to be considered is permanent in-place entombment. This option involves sealing all of the remaining highly radioactive components in a structural integral within the biological shield after removal of fuel assemblies and other readily removable high activity components. This option was generally considered to be rather attractive until recently. This type of option was, for example, originally implemented at the Pathfinder reactor near Sioux Falls, South Dakota, with conversion of the turbine to oil-fired peak load use. Permanent entombment does, however, require a long-term commitment to a surveillance and monitoring program, as well as the guarantee of complete structural integrity for an indefinitely long period of time. This is necessary because of the presence of a large inventory of isotopes with very long half-lives, such as ${ }^{59} \mathrm{Ni}\left(T_{1 / 2}=80,000 \mathrm{y}\right)$ and ${ }^{94} \mathrm{Nb}$ $\left(T_{1 / 2}=20,000 \mathrm{y}\right)$ which do not undergo significant decay on a historical time scale. Thus, permanent onsite entombment is no longer generally considered to be a viable ultimate solution to the decommissioning problem.

In the interest of simplicity and clarity the NRC has recently adopted the following definitions and pseudoacronyms to define the options involved (Calkins 1982):

- Decommission means to remove the property safely from service and dispose of the radioactive residue to allow unrestricted use of the property.

- DECON means to immediately remove all radioactive material to permit unrestricted release of the property. 
- SAFSTOR means to fix and maintain property so that risk to safety is acceptable for the period of storage, followed by decontamination and/or decay to the unrestricted level.

- ENTOMB means to encase and maintain property in a strong and structurally long-lived material (e.g., concrete) to assure retention until radioactivity decays to an unrestricted level.

A thorough review of the practical considerations involved in nuclear facilities decommissioning is given in the U.S. Department of Energy (DOE) Decommissioning Handbook (Manion and LaGuardia 1980). A technical and economic assessment has been carried out for PWR's by Smith, Konzek, and Kennedy (1978) and for BWR's by Oak et al. (1980).

In reviewing the expected problems posed to decommissioning by activation products, it becomes readily apparent that the particular isotopic mix responsible for a given level of problem is to a large extent related to the type of decommissioning scenario considered. If immediate dismantlement is chosen, isotopes with half-lives down to one year or less will be present in significant quantities. With the deferred dismantlement option it is unlikely that isotopes with half-lives shorter than that of ${ }^{60} \mathrm{Co}\left(\mathrm{T}_{1 / 2}=5.3 \mathrm{y}\right)$ would be of significant interest. In both cases, much longer-lived isotopes must be considered as posing a potential disposal hazard. In general, most of the effort in the area of nuclear waste disposal has been focused on problems associated with stabilization of wastes generated by the fuel cycle. While the activity levels produced by the fuel cycle are of course many times higher than those resulting from activation products alone, fuel cycle waste is inherently more compact and thus amenable to a different type of disposal technology, such as vitrification or retrievable storage. The massive components comprising the bioshield, vessels, and internals by their very bulk require a completely different disposal treatment such as near-surface burial. Thus, each component must be considered independently with regard to the risk posed by release of long-lived isotopes.

\subsection{LONG-LIVED ACTIVATION PRODUCTS}

\subsubsection{Scope of Problem}

Long-lived activation products are defined in this context as any radionuclide product of a half-life greater than 5.3 years which can be produced in sensible quantities in a nuclear reactor by the bombardment of neutrons or gamma rays upon a suitable target material. The choice of 5.3 years, the halflife of ${ }^{60} \mathrm{Co}$, is somewhat arbitrary. It is based on the expectation that on a time scale of a few years, ${ }^{60} \mathrm{Co}$ will be of dominant importance. This simply 
serves to delimit the discussion somewhat. Table 1.1 gives a 1 ist of 52 isotopes conforming to that definition. A wide variety of nuclear reaction exit channels were considered. These include $N-\gamma, N-2 N, N-P, N-\alpha, N-D, N-T, N-N^{1}$, neutron induced fission (N-F) and photonuclear reactions. The 1 ist is by no means exhaustive since a number of the more exotic reactions (including reactions induced by secondary protons and complex multiple neutron capture reactions) are in principle possible, but of negligible importance. Most of the isotopes shown in Table 1.1, are in general, of negligible importance because of a variety of nuclear properties and target abundance considerations. This listing simply serves to define the magnitude of the problem. A complete discussion of the nuclear considerations involved is given in Section 2.1. It is evident from an examination of Table 1.1 that a wide variety of isotopes can be produced from the abundant neutron fluxes present under typical nuclear reactor operating conditions. In practice, only a few isotopes are expected to totally dominate the inventory of activation products for any given type of construction material. This is due primarily to the abundance patterns of target elements found in the materials of interest. It should be noted that the product isotope is not necessarily the same chemical element as the target isotope even for direct neutron capture reactions. Technetium-99 $\left(\mathrm{T}_{1 / 2}=213,000 \mathrm{y}\right)$ for example, can be produced in good yield from Mo, a major constituent of Type 304 stainless steel, the most commonly used component of reactor internals. This isotope is normally considered as a fission product in fuel cycle considerations. It is the function of this program to sort out various considerations of that type while ensuring that no important activation product is overlooked in future discussions of reactor decommissioning strategy.

\subsubsection{Review of Existing Information}

Comprehensive information on inventories of long-lived activation products in power reactors is relatively limited to date. Emphasis has tended to be placed mainly on a short list of isotopes, such as ${ }^{60} \mathrm{Co}$ and ${ }^{55} \mathrm{Fe}$. One reason for this is that practical experience with decommissioning of large nuclear facilities is rather limited; however, DOE and a number of utilities are planning several large dismantling projects so this may change somewhat in the near future. Most of the smaller power reactors that have been decommissioned to date used at least temporarily the SAFSTOR or ENTOMB options. Estimates of total radioactive inventory are made as part of the radiological safety analysis for entombment. For example, the Hallam Nuclear Power Facility was estimated to contain $300,000 \mathrm{Ci}$ of activation products at the time of its entombment (Atomics International 1970). The total radioactivity sealed inside containment at the Piqua Nuclear Power Facility was estimated at $260,000 \mathrm{Ci}$ (Atomics International 1969). The analysis conducted for the entombment of the BONUS Facility concluded that about $50,000 \mathrm{Ci}$ of activity were entombed consisting of $71 \%{ }^{55} \mathrm{Fe}, 29 \%{ }^{60} \mathrm{Co}$, and $<1 \%{ }^{63} \mathrm{Ni}$ (Puerto Rico Water Resources Authority 1970). These are fairly representative examples of the type of 
TABLE 1.1. Long-Lived Activation Products with Half-Lives Greater than 5 years

\begin{tabular}{|c|c|c|c|}
\hline I sotope & $\begin{array}{l}\text { Half-Life } \\
(\text { Years })(a) \\
\end{array}$ & Target Element & $\begin{array}{c}\text { Principal } \\
\text { Production Mode } \\
\end{array}$ \\
\hline \multirow{2}{*}{${ }_{1}^{3} \mathrm{~B}_{\mathrm{Be}}$} & 12.3 & $\mathrm{Li}$ & $N-\alpha$ \\
\hline & $1.6 \mathrm{E} 6$ & $\mathrm{Be}$ & $N-Y$ \\
\hline & & B & $N-P$ \\
\hline $26_{\mathrm{A} 1}$ & 5730 & N & $N-P$ \\
\hline \multirow{3}{*}{${ }^{36} \mathrm{Cl}$} & $7.2 \mathrm{E} 5$ & Al & $N-2 N$ \\
\hline & $3.01 E 5$ & Cl & $N-Y$ \\
\hline & & k & $N-\alpha$ \\
\hline $41 \mathrm{Ca}$ & 269 & k & $\mathrm{N}-\mathrm{P}$ \\
\hline $\begin{array}{l}{ }^{4} 1 \\
53 \mathrm{Ca}\end{array}$ & $1.03 E S$ & $\mathrm{Ca}$ & $N-Y$ \\
\hline $\begin{array}{l}3.3 \mathrm{Mn} \\
59_{\mathrm{Ni}}\end{array}$ & $3.7 E 6$ & $\mathrm{Fe}$ & $N=D$ \\
\hline $\begin{array}{ll}69 \\
6 \mathrm{Ni}\end{array}$ & 80000 & $\mathrm{Ni}$ & $N-Y$ \\
\hline${ }_{63}^{60} \mathrm{Co}$ & 5.272 & Co & $N-Y$ \\
\hline $63_{\mathrm{Ni}}$ & 100 & $\mathrm{Ni}$ & $N-Y$ \\
\hline \multirow[t]{2}{*}{${ }^{79} \mathrm{Se}$} & 65000 & $\begin{array}{l}\mathrm{Cu} \\
\mathrm{Se}\end{array}$ & $\begin{array}{c}N-P \\
N-\gamma, N-2 N\end{array}$ \\
\hline & & $\mathrm{Br}$ & $N-P$ \\
\hline $8 \mathrm{l}_{\mathrm{Kr}}$ & & $U$, Th & $N-F$ \\
\hline \multirow{2}{*}{$85_{K r}^{k r}$} & $2.1 E 5$ & $\mathrm{Sr}$ & $N-\alpha$ \\
\hline & 10.7 & U, Th & $N-F$ \\
\hline \multirow{2}{*}{$\begin{array}{l}90 \mathrm{Sr} \\
{ }^{93} \mathrm{Zr}\end{array}$} & 29 & U, Th & $\begin{array}{l}N-P \\
N-F\end{array}$ \\
\hline & $9.5 E 5$ & $2 r$ & $N-Y$ \\
\hline \multirow{2}{*}{$92 m_{\mathrm{Nb}}$} & & $U$, Th & $N-F$ \\
\hline & $2.7 E 7$ & No & $N-2 N$ \\
\hline \multirow{4}{*}{$\begin{array}{l}93 \mathrm{~m}_{\mathrm{Nb}} \\
93_{\mathrm{Mo}} \\
944_{\mathrm{Nb}}\end{array}$} & 12 & $\begin{array}{l}\text { Mo } \\
\text { ND }\end{array}$ & $\begin{array}{c}n-n_{1} \\
n-P \\
n\end{array}$ \\
\hline & 3500 & Mo & $N-\gamma$ \\
\hline & 20000 & ND & $N-\gamma$ \\
\hline & & Mo & $\mathrm{N}-\mathrm{P}$ \\
\hline \multirow{3}{*}{$\begin{array}{l}97 \\
{ }^{98}{ }^{\top \mathrm{Tc}} \\
{ }^{99} \mathrm{Tc} \\
{ }^{\mathrm{T}} \mathrm{Tc}\end{array}$} & $2.6 \mathrm{E} 6$ & $\mathrm{Ru}$ & $N-Y$ \\
\hline & $4.2 E 6$ & $\mathrm{Ru}$ & $\mathrm{N}-\mathrm{P}$ \\
\hline & $2.13 E 5$ & Mo & $N-Y$ \\
\hline \multirow{5}{*}{$\begin{array}{l}107 \mathrm{Pd} \\
108 \mathrm{~m}_{\mathrm{Ag}} \\
113 \mathrm{~m}_{\mathrm{Cd}} \\
121 \mathrm{~m}_{\mathrm{Sn}}\end{array}$} & & $U$, Th & $N-F$ \\
\hline & $6.5 E 6$ & $\mathrm{Pd}$ & $N-\gamma$ \\
\hline & 130 & Ag & $N-\gamma_{1}$ \\
\hline & 14.6 & Cd & $\mathrm{N}-\mathrm{N}^{2}$ \\
\hline & 50 & $\begin{array}{l}\text { Sn } \\
\text { Sb }\end{array}$ & $\begin{array}{l}N-\gamma \\
N-P\end{array}$ \\
\hline \multirow{3}{*}{$\begin{array}{l}129 \mathrm{I} \\
133 \mathrm{Ba} \\
135 \mathrm{Cs}\end{array}$} & $1.59 E 7$ & $\mathrm{Te}$ & $N-\gamma$ \\
\hline & 10.4 & $\mathrm{Ba}$ & $N-P$ \\
\hline & 2.3E6 & $\mathrm{Ba}$ & $N-P$ \\
\hline \multirow{2}{*}{${ }^{137} \mathrm{Cs}$} & & U, Th & $n-F$ \\
\hline & 30.1 & $\mathrm{Ba}_{\mathrm{Th}}$ & $\begin{array}{l}n-P \\
N-F\end{array}$ \\
\hline \multirow{14}{*}{$\begin{array}{l}137 \mathrm{La} \\
145 \mathrm{Pm} \\
146 \mathrm{Sm} \\
150 \mathrm{~m} \\
150 \mathrm{Eu} \\
151 \mathrm{Gd} \\
152 \mathrm{Sm} \\
154 \mathrm{Eu} \\
158 \mathrm{Eu} \\
163_{\mathrm{Tb}} \\
166 \mathrm{~m}_{\mathrm{Ho}} \\
178 \mathrm{~m}_{\mathrm{Hf}} \\
192 \mathrm{ml} \mathrm{Ir} \\
193_{\mathrm{Pt}}\end{array}$} & 60000 & $\mathrm{Ce}$ & $N-4$ \\
\hline & & Sm & $N-\gamma$ \\
\hline & $1.0 \mathrm{E} 8$ & Sm & $N-2 N$ \\
\hline & & Eu & $\mathrm{N}-2 \mathrm{~N}$ \\
\hline & $1.8 \mathrm{E} 6$ & Eu & $N-2 N$ \\
\hline & 93 & $\mathrm{Sm}$ & $N-\gamma$ \\
\hline & 13 & Eu & $N-Y$ \\
\hline & 8.6 & Eu & $N-Y$ \\
\hline & 150 & Tb & $N-2 N$ \\
\hline & 33 & Er & $N-2 N$ \\
\hline & 1200 & Ho & $N-Y$ \\
\hline & 30 & $\mathrm{Hf}$ & $N-Y$ \\
\hline & 241 & I $r$ & $N-Y$ \\
\hline & 50 & $P_{t}$ & $N-Y$ \\
\hline \multirow{2}{*}{$205 \mathrm{~Pb}$} & & Pt & $N-2 N$ \\
\hline & $1.4 \mathrm{E} 7$ & $\mathrm{~Pb}$ & $\begin{array}{c}n-5 N \\
N-\gamma \\
N\end{array}$ \\
\hline 208 & $3.68 \mathrm{E} 5$ & $\begin{array}{l}\mathrm{Pb} \\
\mathrm{Bi}\end{array}$ & $\begin{array}{l}N-2 N \\
N-2 N\end{array}$ \\
\hline $210 m_{B i}$ & $3.5 \mathrm{E} 6$ & $B i$ & $\mathrm{~N}-\mathrm{Y}$ \\
\hline $233 \mathrm{v}$ & $1.58 \mathrm{E} 5$ & Th & $N-Y$ \\
\hline $236 u$ & $2.3 E 7$ & u & $N-Y$ \\
\hline $\begin{array}{l}23 / \mathrm{Np} \\
239 \mathrm{p}\end{array}$ & $2.14 \mathrm{E} 6$ & U & $N-2 N$ \\
\hline & 24390 & U & $N-Y$ \\
\hline
\end{tabular}

(a) $E 6=X 10^{6}$ 
information available from past decommissioning activities. The one exception is the Elk River Reactor, which until recently was the only power reactor in the United States to be completely dismantled. The dismantling operation of the 58.2 MWTh reactor was successfully completed between 1972 and 1974 (United Power Association 1974). An estimated 10,000 $\mathrm{Ci}$ of activated material was disposed of during the decommissioning (Rural Cooperative Power Association 1971). About $90 \%$ of the activity was present in the core shroud with most of the remaining $10 \%$ in the vessel. In addition, $1224 \mathrm{~m}^{3}$ of concrete and $1377 \mathrm{~m}^{3}$ of soil containing low levels of activity were removed for disposal (Rural Cooperative Power Association 1971). As part of that work, a core was taken of the bioshield and subjected to gamma ray analysis. Approximately equal amounts of ${ }^{60} \mathrm{Co}$ and ${ }^{152} \mathrm{Eu}$ were found with minor amounts of ${ }^{22} \mathrm{Na}$. Smith, Konzek and Kennedy (1978) in their reevaluation of that data have commented on the improbability of finding ${ }^{22} \mathrm{Na}$ under those conditions and were surprised they did not see ${ }^{154} \mathrm{Eu}$. They were correct on both accounts, because the principal gamma ray energy of ${ }^{154} \mathrm{Eu}$ is within $0.1 \mathrm{KeV}$ of the principal gamma ray of ${ }^{22} \mathrm{Na}$ and unresolvable even with the high resolution detectors available today. This work is mainly of importance in that it verifies the importance of the europium isotopes in activation of bioshield concrete.

More recently, the Sodium Reactor Experimental (SRE), a small experimental power reactor located near Los Angeles, was successfully decommissioned (Kittinger, Ureda and Conners 1982). In the course of this work it was determined that only the inner $25 \mathrm{~cm}$ of the bioshield contained sufficiently high levels of activation products to require disposal as low level waste. The unactivated portion could thus be safely buried in place. The total volume of contaminated solids removed to offsite burial was $3850 \mathrm{M}^{3}$.

Perhaps the most complete combined experimental and theoretical analysis of activation products was carried out by Woolam (1978) and Woolam and Pugh (1978) for British Magnox reactors. These reactors are gas-cooled graphite reactors of vastly different design from the PWR and BWR designs used in the U.S. Nevertheless, some aspects of this study are very relevant. The study consisted of two parts. In the first phase reported by Woolam (1978), several samples of activated mild steel and concrete were taken from accessible areas during a scheduled outage. The steel samples were subjected to radiochemical analys js to determine the levels of ${ }^{59} \mathrm{Fe},{ }^{54} \mathrm{Mn},{ }^{60} \mathrm{Co},{ }^{1} 10 \mathrm{~m}_{\mathrm{Ag}},{ }^{124},{ }^{25} \mathrm{Sb},{ }^{63} \mathrm{Ni}$, $94 \mathrm{Nb}, 108 \mathrm{~m}_{\mathrm{Ag}},{ }^{152} \mathrm{Eu}$ and $166 \mathrm{~m}_{\mathrm{Ho}}$. The concrete samples were analyzed by gamma

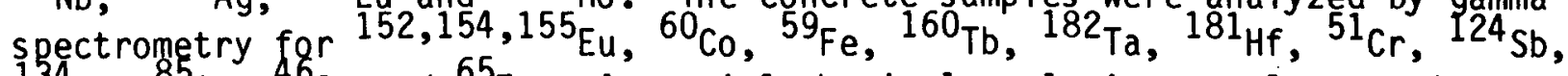
${ }^{134} \mathrm{Cs},{ }^{85} \mathrm{Sr},{ }^{46} \mathrm{Sc}$ and ${ }^{65} \mathrm{Zn}$. A partial chemical analys is was also carried out on the samples to attempt to reconcile the measured activities with neutron transport calculations. It was only possible to do this in a somewhat qualitative manner since the samples available were from regions not readily amenable to accurate neutron transport calculation, a persistent difficulty in the present work as well. It is rather clear that this work could be best accomplished 
during an actual decommissioning project. Woolam (1978) used a pair of indices which he defines as the dose contribution and disposal toxicity indices for prioritizing the relative importance of various isotopes on different time scales. The indices were used to treat independently the problems of dismantling and disposal. The results of this study indicated that on a 10 year time scale the dismantling dose would be dominated in mild steel by ${ }^{60} \mathrm{Co}$, but in concrete, ${ }^{152} \mathrm{Eu}$ would dominate, on a 100 -year time scale $108 \mathrm{~m}_{\mathrm{Ag}}$ and ${ }^{94} \mathrm{Nb}$ tend to dominate in steel, whereas ${ }^{152} \mathrm{Eu}$ is still the most important dose producing isotope in concrete. The situation is considerably different from the standpoint of debris disposal, with ${ }^{63} \mathrm{Ni}$ dominating the situation for a 10 to 100-year time scale in steel, and ${ }^{59} \mathrm{Ni}$ important on a greater than 1000-year time scale. Europium-152 dominates the disposal problem for concrete on a 10-year scale, but on the longer time scale of 100 years or more, the very long-lived ${ }^{41} \mathrm{Ca}$ dominates. . The indices for dose and disposal toxicity advocated by Wollam (1978) appear to be useful for prioritizing the relative importance of various isotopes. The dose toxicity index approach has consequently been adapted to the present work as well. The second stage of the Magnox Project as reported by Woolam and Pugh (1978) is more theoretical in nature. Representative chemical compositions of major construction materials were combined with appropriate cross sections and neutron transport information to calculate expected activation levels in stainless steel, mild steel, graphite, and concrete. These data were then used to calculate activation levels and dose rates as a function of shutdown time. A detailed inventory of radioactive

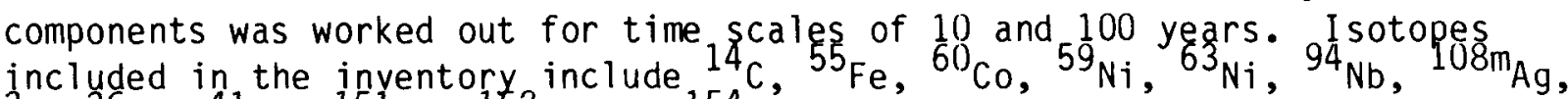
included in the inventory include ${ }^{14} \mathrm{C}$,
${ }^{3} \mathrm{H},{ }^{36} \mathrm{Cl},{ }^{4} 1_{\mathrm{Ca}},{ }^{15} 1_{\mathrm{Sm},}{ }^{152} \mathrm{Eu}$ and ${ }^{154} \mathrm{Eu}$.

A similar, though more limited study, has recently been carried out on the decommissioned Gudremmingen Unit A Nuclear Power Station in the Federal Republic of Germany (Bergemann et al. 1982). This study included chemical and radiochemical analysis of bioshield cores, Charpy-V-notch samples of vessel steel and samples of the austenitic steel feedwater sparger ring. Steel samples were analyzed for ${ }^{60} \mathrm{Co},{ }^{54} \mathrm{Mn}$ and ${ }^{63} \mathrm{Ni}$. Bioshield samples were analyzed for ${ }^{60} \mathrm{Co},{ }^{54} \mathrm{Mn},{ }^{63} \mathrm{Ni},{ }^{134} \mathrm{Cs}$ and ${ }^{152} \mathrm{Eu}$. Neutron flux calculations by one- and two-dimensional neutron diffusion codes were used to calculate expected activation levels in those samples. In general, excellent agreement was obtained. This demonstrated the reliability of the calculation method provided adequate chemical information is available. This study showed a total activity inventory for the reactor pressure vessel and internals of $1.4 \times 10^{6} \mathrm{Ci} 6$ years after shutdown. It was also found that activation of the bioshield above the limit for unrestricted release in the Federal Republic of Germany (FRG) was confined to the inner concrete ring, crossing the $10^{-10} \mathrm{Ci} / \mathrm{g}$ level at about $110 \mathrm{~cm}$ shield thickness. 
The most comprehensive approach to the activation products problem carried out in the United States was that adopted by Smith, Konzek, and Kennedy (1978) as part of their PWR Decommissioning Assessment Program. A similar approach was also used by 0ak et al. (1980) in the parallel program applied to a BWR. Detailed neutron transport calculations were carried out for the reference reactors using the one-dimensional diffusion code ANISN (Engle 1967). Representative compositions of mild steel, stainless steel and concrete were obtained from a variety of literature sources. The neutron transport data, collapsed into three energy groups, were combined with the composition data to calculate expected activation levels for 30 effective power years (EFPY) via code ORIGEN (Bell 1973). By integrating over the axial flux distribution, an approximate radionuclide inventory was obtained for a variety of long-lived
activation products including $3 \mathrm{H},{ }^{14} \mathrm{C},{ }^{36} \mathrm{Cl},{ }^{39} \mathrm{Ar}, 4{ }_{\mathrm{Ca}} 6{ }^{6} \mathrm{Co},{ }^{59} \mathrm{Ni}, 63 \mathrm{Ni}$,

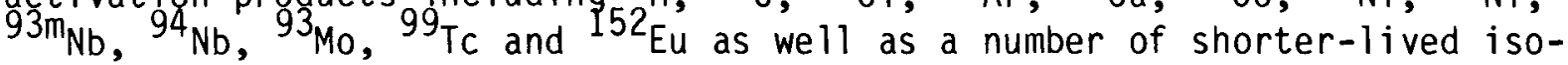
topes. The total estimated activity in neutron-activated components at shutdown after 30 EFPY was about 5 million curies for a PWR and slightly higher for a BWR. From these calculations it was shown that the decay of ${ }^{63} \mathrm{Ni}$ controls the total specific activity after about 15 years, while ${ }^{60}$ Co dominates the dose rate for up to 80 years. After that time the dose rate is determined by ${ }^{94} \mathrm{Nb}$. They concluded that the radiation dose rate from the internal components of the reactor would remain above acceptable levels for thousands of years and for that reason permanent entombment (ENTOMB) is not a satisfactory decommissioning approach. These two studies provided a reasonably good understanding of the activation products situation in large LWR nuclear generating stations. It is the purpose of the present program to supplement that information with a better data base of compositional information, as well as to provide confirmation of the presence of such isotopes at ${ }^{94} \mathrm{Nb}$.

\subsubsection{Description of Research Program}

To supplement information gaps in the programs previously described in Section 1.2.2, a three-phase program was carried out to provide a more focused approach to the long-lived activation products problem. Central to the goals of the program was the need to assure that no important mode of activation capable of having an adverse effect on decommissioning planning was being overlooked. One of the major areas of uncertainty in the Smith, Konzek and Kennedy (1978) assessment was the lack of comprehensive compositional information on the major construction materials of interest. In particular, information on key trace elements such as europium was unavailable. In addition, where reference compositional information could be inferred, the range of variability was poorly known. The present program was designed to correct some of these deficiencies by providing major, minor, and trace element analyses on samples of concrete, rebar, structural steel, vessel steel, vessel cladding, and stainless steel internals. All utilities in the country with reactors under construction were contacted and samples of opportunity obtained with good 
geographical diversity. In addition to whole concrete samples, individual concrete components including cement, sand, aggregate, and fly ash were obtained to permit assessment of the relative importance of various components in the concrete mix in producing long-lived activation products. In addition to the construction or archive samples obtained through the utilities, a number of samples including activated concrete and steel were obtained from operating or shutdown reactors. These samples were taken as part of a second related program aimed at assessing all other sources of radioactive contamination present in LWR stations. Shutdown reactors sampled include Pathfinder, Humboldt Bay, and Indian Point No. 1. Samples were also taken at two operating plants, Turkey Point and Monticello, during scheduled shutdowns. A chemical analysis for up to 52 elements was carried out on these samples by a combination of $X$-ray fluorescence and instrumental neutron activation analysis supplemented by special single element techniques on selected samples.

To utilize the chemical analysis results obtained in the first task for calculating expected activation levels, a computer code (ACTIV) was written to satisfy the needs of that task. Initial attempts to carry out these calculations using the three group generalized activation code ORIGEN proved unsatisfactory due to the inadequacy of its data base for long-lived isotopes. Rather than attempt to adapt this rather large and cumbersome code to the needs of this program, a simpler series of semi-interactive codes were written to run on a PDP-11 or VAX minicomputer. The program accesses a series of composition, flux, and cross-section libraries, which can be combined in any appropriate order, allowing complete flexibility of use and relative ease of data base maintenance. A careful evaluation of the best available cross-section information was made in constructing and maintaining these libraries and reevaluated several times before carrying out final calculations. Neutron flux information used in these calculations was taken from the ANISN calculations of Smith, Konzek and Kennedy (1978) and Oak et al. (1980) supplemented by the code DOT calculations of Gritzner et al. (1977).

The third phase of the program was designed to verify the presence of long-lived activation products in selected samples representative of the major construction materials involved. Samples obtained for radiochemical analysis include stainless steel internals, vessel steel and bioshield concrete. Samples were first subsampled in order to reduce them to manageable levels of activity for laboratory analysis. They were then subjected to nondestructive gamma ray analysis. Following nondestructive analysis, the samples were digested and subjected to a series of single element radiochemical separations

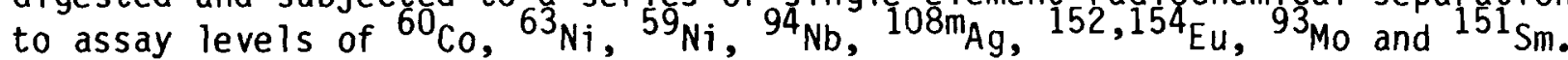



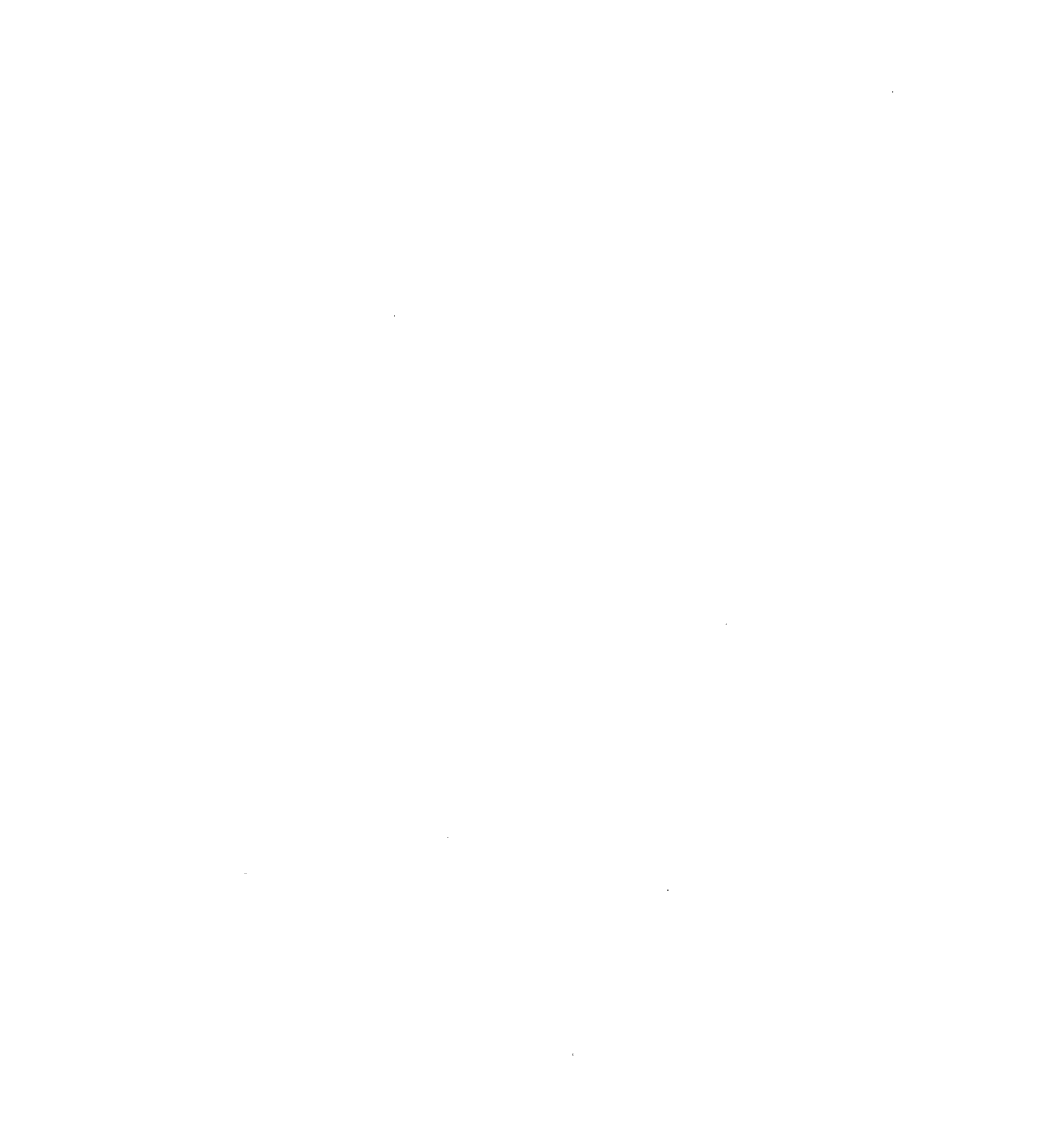


\subsection{REVIEW OF NUCLEAR PROPERTIES}

To fully understand the setting in which nuclear activation occurs in a power reactor, a thorough understanding of the nuclear considerations involved is useful. This will be reviewed both from the standpoint of general reaction systematics as well as from a standpoint of isotope-specific properties for some of the more important activation products.

\subsection{ACTIVATION REACTIONS}

\section{$2.1 .1 \underline{\mathrm{N}-\gamma}$}

In general, the most important type of activation reaction is thermal neutron capture in which an isotope of mass $A$ captures a neutron to produce a product of mass $A+1$, which can, in some instances, be the short-lived parent of a longer-lived daughter at atomic number $Z+1$ or $Z-1$. Capture rates are normally maximal in the thermal region, which, at room temperature, is $0.025 \mathrm{eV}$. Neutron capture cross sections are defined for a thermal region ( 0 to $0.5 \mathrm{eV}$ ) and an epithermal region $(0.5 \mathrm{eV}-1 \mathrm{MeV})$. Neutron capture rates can vary enormously from isotope to isotope, depending upon nuclear structure factors and can span some nine to ten orders of magnitude in extreme cases. This range of variability is illustrated in Figure 2.1 for some selected cases.

In the epithermal region between $1 \mathrm{eV}$ and a few KeV, especially for elements with intermediate and high mass numbers, there are of ten particular energies for which the interaction rate is exceptionally high. The rate of occurrence of a particular reaction in this resonance region is proportional to the integral of the cross section as a function of neutron energy multiplied by the flux density. This is referred to as the resonance integral. In the case of LWRs, neutrons are not well thermalized, particularly near the in-core region. This results in a rather large contribution from the resonance integral for some isotopes. Unfortunately, resonance integrals are not always well known, particularly for very long-lived isotopes. In that case it is necessary to assume a smooth background contribution to the resonance integral comprising a factor of 0.45 times the thermal cross section. This represents a minor source of uncertainty in calculating expected capture rates. Figure 2.2 shows the relative importance of the resonance contribution for some key isotopes.

\subsubsection{N-2N Reaction}

Neutrons produced by fission have a distribution of energies ranging up to about $15 \mathrm{MeV}$. These high-energy neutrons are eventually slowed down to thermal energies by repeated elastic and inelastic scattering interactions with the moderating medium. At most points in the reactor outside of the core, the flux in the high-energy region is considerably reduced over the low energy region. 


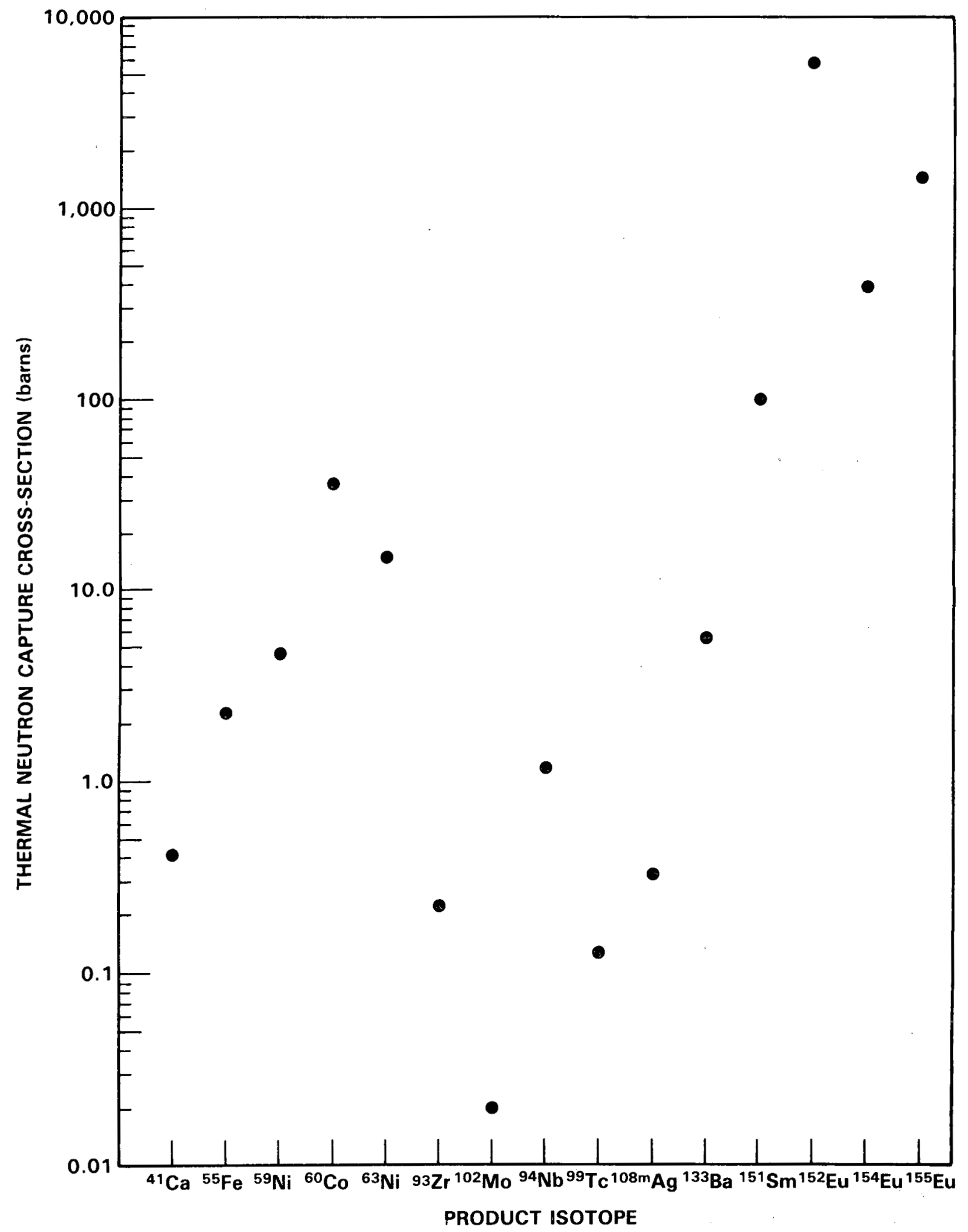

FIGURE 2.1. Representative Neutron Capture Cross-Sections for Selected Isotopes 


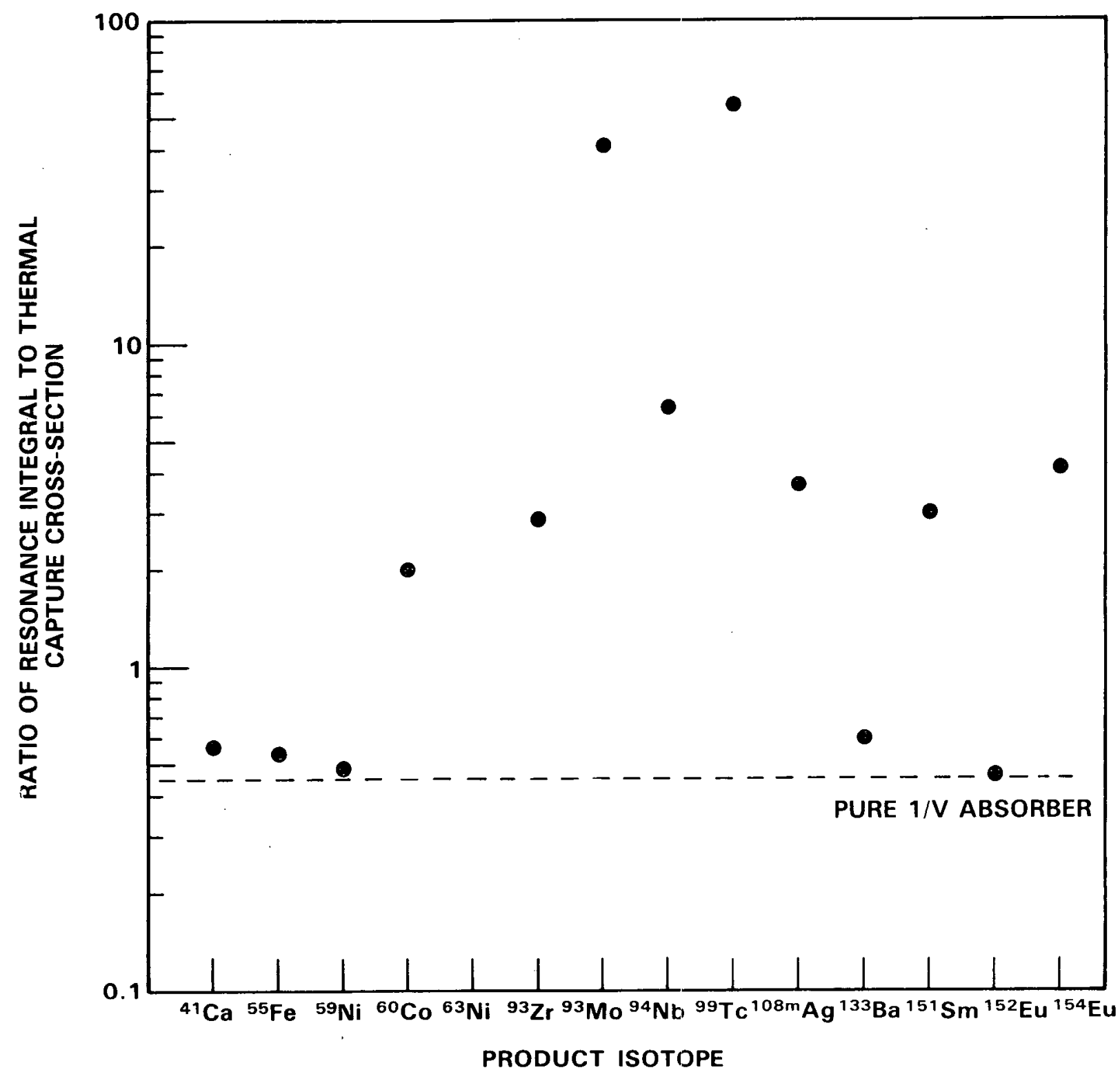

FIGURE 2.2. Relative Contribution of Resonance Capture for Selected Isotopes

Nevertheless, neutrons in that region are capable of inducing activation reactions, one of the more prominent of which is the $\mathrm{N}-2 \mathrm{~N}$ reaction with the product nucleus of mass A-1. The threshold for the reaction is dominated by the neutron-binding energy, consequently, this type of reaction is typically limited to energies above about $8 \mathrm{MeV}$ and is thus relatively unimportant compared to neutron capture. $\mathrm{N}-2 \mathrm{~N}$ reactions are mainly of interest in the high mass region where cross sections above the threshold can exceed two barns. 
Table 2.1 shows a number of possible $\mathrm{N}-2 \mathrm{~N}$ reactions and their respective threshold energies. Most involve relatively exotic target elements. In addition, some of the possible $\mathrm{N}-2 \mathrm{~N}$ reactions shown compete with thermal neutron capture and thus result in a trivial contribution. An example would be ${ }^{60} \mathrm{Ni}(\mathrm{n}, 2 \mathrm{n}){ }^{59} \mathrm{Ni}$ versus ${ }^{58} \mathrm{Ni}(n, \gamma){ }^{59} \mathrm{Ni}$. The latter reaction is expected to dominate by at least three or four orders of magnitude.

\section{$2.1 .3 \quad \gamma-\mathrm{N}$}

In addition to the copious flux of neutrons present in an operating reactor, there is also a very high flux of photons or gamma rays produced by a variety of processes including fission, thermal neutron capture, radiative neutron capture, radioactive decay and beta induced bremsstrahlung. In principle, the high energy end of the photon spectrum is capable of producing some minor level of activation by the photonuclear evaporation process. The same threshold considerations apply as for $\mathrm{N}-2 \mathrm{~N}$ reactions since the net reaction is identical. Photonuclear reactions are coupled via the electromagnetic rather than the strong interaction and consequently have much lower interaction rates per particle. Neutron transport calculations carried out by Gritzner et al. (1977) for both PWR and BWR geometries show that the photon flux per energy group above $8 \mathrm{MeV}$ is approximately the same as the neutron flux per energy group in the same region. Photonuclear reactions can thus be safely ignored because they are in any case in a practical sense indistinguishable from the equivalent $\mathrm{N}-2 \mathrm{~N}$ reaction.

TABLE 2.1. N-2N Reactions

\begin{tabular}{|c|c|c|c|}
\hline $\begin{array}{l}\text { Product } \\
\text { I sotope }\end{array}$ & $\begin{array}{l}\text { Target } \\
\text { Isotope } \\
\end{array}$ & $\begin{array}{c}\text { Abundance } \\
(\%) \\
\end{array}$ & $\mathrm{Q}(\mathrm{MeV})$ \\
\hline $26_{A 1}$ & $27 \mathrm{Al}$ & 100 & 13.06 \\
\hline${ }^{55} \mathrm{Fe}$ & ${ }^{56} \mathrm{Fe}$ & 91.8 & 11.20 \\
\hline${ }^{59} \mathrm{Ni}$ & $60_{\mathrm{Ni}}$ & 26.1 & 11.39 \\
\hline${ }^{79} \mathrm{Se}$ & ${ }^{80} \mathrm{Se}$ & 49.8 & 10.02 \\
\hline${ }^{92} \mathrm{Nb}$ & ${ }^{93} \mathrm{Nb}$ & 100 & 8.83 \\
\hline $133 \mathrm{Ba}$ & $134 \mathrm{Ba}$ & 2.4 & 9.47 \\
\hline${ }^{146} \mathrm{Sm}$ & $147 \mathrm{Sm}$ & 15.0 & 6.35 \\
\hline $158 \mathrm{~Tb}$ & ${ }^{159} \mathrm{~Tb}$ & 100 & 8.13 \\
\hline${ }^{163} \mathrm{Ho}$ & ${ }^{164} \mathrm{Er}$ & 1.6 & 8.84 \\
\hline $193 p_{t}$ & ${ }^{194} \mathrm{Pt}$ & 32.9 & 8.38 \\
\hline${ }^{205} \mathrm{~Pb}$ & ${ }^{206} \mathrm{~Pb}$ & 24.1 & 8.09 \\
\hline $208_{B i}$ & ${ }^{209} \mathrm{Bi}$ & 100 & 7.46 \\
\hline${ }^{237} \mathrm{~Np}$ & $238 \mathrm{v}$ & 99.3 & 10.11 \\
\hline
\end{tabular}




\subsubsection{N-X (Charged Particle Reactions)}

A number of nuclear activation reactions are possible at reactor neutron energies involving charged particles in the exit channel. This includes N-P, $N-D$, and $N-\alpha$ reactions primarily. These reactions typically have much lower energy thresholds than $\mathrm{N}-2 \mathrm{~N}$ reactions and are, in most cases, exoergic. This is to some extent counter-balanced by the necessity for the outgoing particle to overcome the coulomb repulsion barrier to escape from the nucleus. Thresholds for charged particle reactions thus consist of two parts, an energy threshold term representing the mass difference between initial and final states and a coulomb barrier term. The coulomb barrier is not in itself an absolute threshold because particles of lower energy can escape through the barrier by quantum mechanical tunneling; however, it severely limits the interaction cross section below that level. Table 2.2 lists a number of representative activation reactions involving charged particles in the exit channel together with the energy threshold $Q$, the coulomb barrier $V$ and the total energy threshold T. The coulomb repulsion term $V$ is given by

$$
V=\frac{\mathrm{z}_{1} \mathrm{z}_{2} \mathrm{e}^{2}}{\mathrm{R}_{1}+\mathrm{R}_{2}}
$$

where $R=1.6 \times 10^{-13} \mathrm{~A} 1 / 2 \mathrm{~cm}$. $\mathrm{Z}$ represents the charge of the product nucleus and the outgoing particle, respectively, and $A$ is the corresponding atomic number. $R$ is the appropriate nuclear radius. The subscripts on $Z$ and $R$ are used to denote the respective nuclei. From this it can be seen that this type of reaction is mainly of importance for target elements of low atomic number. Probably the best known $N-P$ rection is ${ }^{14} \mathrm{~N}(n, p){ }^{14} \mathrm{C}$ which, due to its relatively low total energy threshold, has an appreciable interaction cross section even at thermal energies. The most prolific $\mathrm{N}-\alpha$ reaction is the well known $6_{L i(n, \alpha)}{ }^{3}$ reaction. This reaction has the minimum possible coulomb barrier and is highly exoergic due to the stabilizing effect of the alpha particle binding energy. $\mathrm{N}-\alpha$ thresholds go up rapidly with atomic number due to the coulomb term. The only other isotope of importance potentially produced by this mechanism is ${ }^{36} \mathrm{C} 1$. The only $\mathrm{N}-\mathrm{D}$ reaction of note is that producing $53 \mathrm{Mn}$. It has a very high threshold due to the fact that two nucleons are removed. For the same reason $N-T$ reactions have even higher thresholds and are not of significance at reactor energies except for the special case of the aforementioned ${ }^{6} \mathrm{Li}$ reaction in which tritium is the residual nucleus.

$2.1 .5 N, N^{1}, \gamma-\gamma^{1}$ (Inelastic Scattering)

Another possible type of activation reaction is inelastic scattering of either neutrons or photons in which a portion of the energy of the incoming particle is absorbed by the target nucleus with no net change in nucleon number. 
TABLE 2.2. Activation Reactions Involving Charged Particles

\begin{tabular}{|c|c|c|c|c|c|c|}
\hline $\begin{array}{l}\text { Product } \\
\text { I sotope }\end{array}$ & $\begin{array}{l}\text { Target } \\
\text { Isotope }\end{array}$ & $\begin{array}{c}\text { Abundance } \\
(\%)\end{array}$ & Reaction & $Q(\mathrm{MeV})$ & $\mathrm{V}(\mathrm{MeV}$ & $\mathrm{T}(\mathrm{MeV})$ \\
\hline $10_{\mathrm{Be}}$ & $10_{B}$ & 19.8 & $N-P$ & 0.23 & 1.14 & 0.91 \\
\hline${ }^{14} \mathrm{C}$ & $14_{N}$ & 99.6 & $N-P$ & -0.63 & 1.58 & 0.95 \\
\hline${ }^{63} \mathrm{Ni}$ & ${ }^{63} \mathrm{Cu}$ & 69.1 & $N-P$ & -0.72 & 5.07 & 5.17 \\
\hline${ }^{79} \mathrm{Se}$ & ${ }^{79} \mathrm{Br}$ & 50.7 & $N-P$ & -0.62 & 5.79 & 5.17 \\
\hline $92_{\mathrm{Nb}}$ & $92 \mathrm{Mo}$ & 14.8 & $N-P$ & -0.42 & 6.70 & 6.28 \\
\hline${ }^{94} \mathrm{Nb}$ & $94 \mathrm{Mo}$ & 9.1 & $N-P$ & 1.26 & 6.70 & 7.96 \\
\hline${ }^{12} 1_{S n}$ & ${ }^{121}{ }_{S b}$ & 57.3 & $N-P$ & -1.16 & 7.58 & 6.42 \\
\hline${ }^{135} \mathrm{Cs}$ & ${ }^{135} \mathrm{Ba}$ & 6.5 & $N-P$ & -0.58 & 8.09 & 7.51 \\
\hline${ }^{137} \mathrm{Cs}$ & $137 \mathrm{Ba}$ & 11.2 & $N-P$ & 0.39 & 8.09 & 7.70 \\
\hline $53 \mathrm{Mn}$ & ${ }^{54} \mathrm{Fe}$ & 5.8 & $N-D$ & 6.63 & 4.74 & 11.37 \\
\hline $3_{H}$ & ${ }^{7} \mathrm{Li}$ & 92.5 & $N-\alpha$ & -5.60 & 0.59 & -5.01 \\
\hline${ }^{36} \mathrm{Cl}$ & $39_{K}$ & 93.3 & $N-\alpha$ & -1.36 & 6.26 & 4.90 \\
\hline${ }^{81}{ }_{K r}$ & ${ }^{84} \mathrm{Sr}$ & 0.56 & $N-\alpha$ & -2.66 & 10.97 & 8.31 \\
\hline $14_{N}+{ }^{3} \mathrm{H}$ & 160 & 99.8 & $N-T$ & 14.50 & 1.60 & 16.10 \\
\hline${ }^{54} \mathrm{Mn}+{ }^{3} \mathrm{H}$ & ${ }^{56} \mathrm{Fe}$ & 91.8 & $N-T$ & 11.93 & 4.20 & 16.23 \\
\hline
\end{tabular}

The target nucleus is raised to an excited state which can be a long-lived metastable. Two such cases are shown in Table $1.1,93 \mathrm{~m}_{\mathrm{Nb}}\left(\mathrm{T}_{1 / 2}=12 \mathrm{y}\right)$ and $113 \mathrm{~m} C d\left(T_{1 / 2}=14.6 \mathrm{y}\right)$. They are included for completeness.

\subsubsection{N-F (Neutron Induced Fission)}

The remaining type of activation process considered is neutron induced fission. This is primarily of interest in bioshield materials, which being of geologic origin can contain significant amounts of uranium and thorium. Fission activation will thus either occur due to direct fission of naturally abundant $235 \mathrm{U}$, or due to multiple neutron capture. Thorium-232 can capture a neutron to produce fissionable $233 \mathrm{U}$ which produces fission products by capturing a second neutron. The same consideration applies to the $238 \mathrm{~J}-239 \mathrm{Pu}$ system. Fission products produced in this manner are likely to be of minor importance compared to fuel cycle derived fission product contamination but are included for completeness. 


\subsection{ISOTOPE PROPERTIES}

A number of activation products studies including this one have demonstrated that a few isotopes tend to dominate hazard potential in reactor construction materials. These isotopes deserve special attention with respect to production mode and decay properties.

\subsubsection{Gamma Emitters}

The primary level of concern about activation products from a standpoint of dismantlement revolves around isotopes emitting energetic gammas. Fortunately, this involves a relatively limited list of isotopes with half-lives on the greater than 5-year time scale.

$$
\text { 2.2.1.1 }{ }^{60} \mathrm{Co}_{\mathrm{O}}
$$

Cobalt-60 is produced almost entirely by thermal and epithermal neutron capture on $100 \%$ abundant ${ }^{59} \mathrm{Co}$. Although other production modes, including ${ }^{60} \mathrm{Ni}(n, p){ }^{60} \mathrm{Co}$ and ${ }^{63} \mathrm{Cu}(n, \alpha){ }^{60} \mathrm{Co}_{\text {are in principle possible, the relatively } h i g h}$ neutron capture cross section ( 37 barns) and the fact that cobalt is a rather common impurity particularly in stainless steel render alternate production mechanisms insignificant. Cobalt-60 ( $\left.T_{1 / 2}=5.27 \mathrm{y}\right)$ decays by emission of a medium energy beta particle $(0.32 \mathrm{MeV}, 96 \%)$ to the $2.5057 \mathrm{MeV}$ level of ${ }^{60} \mathrm{Ni}$ which, in turn, decays to the ground state with the emission of 1.173 and $1.332 \mathrm{MeV}$ gamma rays with close to $100 \%$ abundance. This combination of properties makes ${ }^{60}$ Co the dominant dose producing isotope in the reactor interior on the 10 -year time scale. The production rate of ${ }^{60} \mathrm{Co}_{0}$ is sufficiently high in the high flux region near the core that a substantial portion (up to one-third) of the stable cobalt may be transmuted over the life of the reactor.

$$
2.2 .1 .2 \underline{152,154_{E u}}
$$

The two europium isotopes are the dominant activation products in bioshield concrete on a time scale of 10 to 20 years or longer. Both have very large neutron capture production cross sections, 5900 barns for 152 and 390 barns for 154 . Europium-152 is produced primarily by thermal neutrons, whereas 154 also has a rather substantial resonance integral (1635 barns). To further complicate matters, europium-152 itself has an extremely high burn-up cross section (13,000 barns) so that in regions of high flux, essentially all of the europium can be converted to 153 and 154 with the 151 and 152 totally depleted. Under lower flux conditions typical of the bioshield area, burn-up is far less important, but the expected isotope ratio is nonetheless variable, depending upon thermalization parameters. Both isotopes have particularly complex decay schemes. Europium-152 $\left(\mathrm{T}_{1 / 2}=13 \mathrm{y}\right)$ has the somewhat unusual property of decaying both by beta emission and by electron capture. Beta 
decays to a number of excited states in ${ }^{152}$ Gd account for $27 \%$ of the decay rate with most of the remainder populating excited states in ${ }^{152} \mathrm{Sm}$ by electron capture. The positron branch is of negligible importance. The resulting gamma cascade is very complex with intense gamma rays ranging in energy from $122 \mathrm{KeV}$ to $1408 \mathrm{KeV}$. A typical gamma ray spectrum of ${ }^{152}$ Eu shows more than 30 peaks greater than $1 \%$ abundant. The decay scheme of ${ }^{154} \mathrm{Eu}\left(T_{1 / 2}=8.5 \mathrm{y}\right)$ is somewhat less complex decaying primarily by beta emission to a number of excited states in $154 \mathrm{Gd}$. Intense gamma ray peaks include those at $123,724,876,996,1005$ and $1278 \mathrm{KeV}$. There are, as well, numerous less intense peaks.

\section{$2.2 .1 .3 \quad 94_{\mathrm{Nb}}$}

Niobium-94 $\left(T_{1 / 2}=20,000 y\right)$ is produced by thermal neutron capture from $100 \%$ abundant ${ }^{93} \mathrm{Nb}$ with a cross section of 1.15 barns. It decays by beta emission with a maximum beta energy of $473 \mathrm{KeV}$ to a single level in $94 \mathrm{Mo}$ at $1574 \mathrm{KeV}$. A cascade of two $100 \%$ abundant gammas of 703 and $871 \mathrm{KeV}$ each results. Since Stevens and Pohl (1977) pointed out that presence of high levels of niobium in reactor internals stainless would lead to production of significant amounts of the very long-lived ${ }^{94} \mathrm{Nb}$, a good deal of attention has been focused on this isotope. For long deferral intervals prior to dismantlement, it may in fact represent the principal contributor to personnel exposure during dismantlement.

$$
2.2 .1 .4 \underline{108 \mathrm{~m}_{\mathrm{Ag}}}
$$

Silver-108m $\left(T_{1 / 2}=130 \mathrm{y}\right)$ is produced by thermal neutron capture on $52 \%$ abundant $107 \mathrm{Ag}$. The neutron capture cross section for this isotope has been revised downward considerably in recent years. Woolam (1978b.) concluded from a survey of the literature that the generally accepted value of three barns was about an order of magnitude too high. The currently accepted value according to Mughabghab, Divadeenam and Holden (1981) is $0.33 \pm 0.08$ barns. Radiochemical measurements made by Woolam (1978a) on activated Magnox reactor components resulted in a factor of five disagreement between silver content estimates based on $110 \mathrm{~m}_{\mathrm{Ag}}$ and $108 \mathrm{~m}_{\mathrm{Ag}}$, suggesting that the cross section may still be lower yet. It is not clear, however, in that work whether or not the rather large resonance integral to produce $110 \mathrm{~m}_{\mathrm{Ag}}$ was properly accounted for in the calculation. The reduced cross section considerably diminishes the importance of this isotope for general decommissioning considerations, however, the use of large amounts of silver in PWR control rods will nonetheless result in a large inventory of $108 \mathrm{~m} \mathrm{Ag}$ in the reactor at the time of shutdown. Silver-108 $\mathrm{m}$ decays primarily by electron capture $(91 \%)$ to ${ }^{108} \mathrm{Pd}$ resulting in a series of energetic gammas of 434,614 , and $722 \mathrm{KeV}$, respectively. 


\section{$2.2 .1 .5 \quad 133_{\mathrm{Ba}}$}

Barium-133 $\left(T_{1 / 2}=10.7 \mathrm{y}\right)$ is produced by a combination of epithermal neutron capture reactions on $0.1 \%$ abundant ${ }^{132} \mathrm{Ba}$. Barium-132 has a neutron capture cross section of only 0.76 barns and a resonance integral of eight barns. Normally this isotope should be of negligible importance, however, significant amounts of ${ }^{13} \mathrm{Ba}$ can be produced in concrete containing barite as a high density aggregate. This apparently was the case with the North Carolina State University research reactor currently being decommissioned, which shows relatively high levels of ${ }^{133} \mathrm{Ba}$ in the bioshield concrete. Barium-133 emits a series of relatively low energy gammas, at $276,302,356$, and $382 \mathrm{KeV}$.

\subsubsection{Other Gamma Emitters}

In addition to the isotopes mentioned above, a number of the other potential activation products shown in Table 1,1 emit energetic gamma rays These include ${ }^{26} \mathrm{Al},{ }^{92} \mathrm{Nb},{ }^{137} \mathrm{Cs},{ }^{158} \mathrm{~Tb}, 166_{\mathrm{Ho}}, 178 \mathrm{~m}_{\mathrm{Hf}},{ }^{192 \mathrm{~m} 2} \mathrm{Ir}, 193_{\mathrm{Pt}}$, and $208_{\mathrm{Bi}}$. These isotopes should result in a negligible dose contribution due to direct activation. There is, of course, the possibility of a large inventory of ${ }^{137} \mathrm{Cs}$ that may be present due to fuel ruptures. Other sources of gamma radiation include beta-induced bremsstrahlung and inner bremsstrahlung from electron capture isotopes. The latter effect is rather important for ${ }^{59} \mathrm{Ni}$ and will be discussed separately.

\subsubsection{Pure Beta Emitters}

Studies of dose effects related to decommissioning activities such as those carried out by Smith, Konzek and Kennedy (1978) have amply demonstrated that pure beta emitters do not represent a serious contribution to dose during dismantling operations due to the low penetrating power of beta radiation. In considering potential disposal hazards, however, all abundantly produced isotopes must be considered.

\subsubsection{1 ${ }^{3} \mathrm{~T}$}

Tritium can be produced in a reactor by several mechanisms. Neutron capture on deuterium is possible though of relatively low yield in LWR's due to the low natural abundance of deuterium $(0.015 \%)$ combined with its extremely low neutron capture cross section $(0.53 \mathrm{mb})$. This reaction is, of course, considerably more important in $\mathrm{D}_{2} \mathrm{O}$-moderated reactor designs such as the Canadian CANDU for example or in the numerous $\mathrm{D}_{2} 0$ moderated research reactors around the world. N-T reactions by fast neutrons are of negligible importance. The thresholds for this reaction on the two most abundant targets present, ${ }^{56} \mathrm{Fe}$ and 160 , are both over $16 \mathrm{MeV}$. Bioshield materials will, of course, contain small amounts of Li. Tritium is thys expected to be present in the bioshield due to the nighly sensitive $6_{\mathrm{Li}}(n, \alpha)^{3} \mathrm{~T}$ reaction. Tritium $\left(T_{1 / 2}=12.33\right.$ y) decays by 
emission of a beta with an $18.6 \mathrm{KeV}$ endpoint. The rather low beta energy results in a relatively low hazard potential for tritium. However, it is very mobile in the environment.

\section{$2.2 .2 .2 \quad 10_{\mathrm{Be}}$}

Beryllium-10 is something of an interesting curiosity as an activation product. Production by direct neutron capture on $100 \%$ abundant ${ }^{9} \mathrm{Be}$ is unlikely except perhaps in research reactors that use beryllium reflectors to produce neutron beams. In any case, the thermal capture cross section is small ( $8 \mathrm{mb}$ ). Table 1.3 reveals that the $N-P$ reaction on $1 O_{B}\left[1 O_{B}(N, P)^{1} O_{B e}\right]$ has a similar threshold to that of the well-known $N-P$ reaction producing ${ }^{14} \mathrm{C}$. The best experimental value for the reactor spectrum-averaged cross section is an upper limit of 0.18 barns. Since the atomic number of beryllium lies outside of the semiempirical formulation used in this work, code THRES2, (Pearlstein 1975, Pearlstein 1973) it is difficult to estimate. The abundant use of boron for reactor power level control suggests that a considerable amount of $10_{\mathrm{Be}}$ may be produced in control rods, shim rods, and in primary reactor coolant when boric acid is used as soluable poison. Beryllium-10 $\left(T_{1 / 2}=1.6 \times 10^{6} \mathrm{y}\right)$ decays by beta emission with a $556 \mathrm{KeV}$ beta endpoint.

$$
2.2 .2 .3 \quad{ }^{14} \mathrm{C}
$$

Carbon-14 is produced in a reactor primarily by the $\mathrm{N}-\mathrm{P}$ reaction on nitrogen. As the principal component of the atmosphere, nitrogen occurs as a highly variable trace impurity in virtually all materials including steel and concrete. Carbon-14 $\left(\mathrm{T}_{1 / 2}=5730 \mathrm{y}\right)$ decays by beta emission with a $156 \mathrm{KeV}$ endpoint.

$$
2.2 .2 .4 \quad 63 \mathrm{Ni}
$$

Nickel-63 is by far the most abundant activation product expected to be present in a LWR on the time scale of deferred dismantlement. Its half-life of 100 years makes its production optimal for that time scale. It is produced by direct neutron capture on nickel with a 14.6 barns cross-section. The problem is somewhat minimized by the relatively low abundance of the target isotope, $62 \mathrm{Ni}(3.6 \%)$. This is offset by the presence of large amounts of $\mathrm{Ni}$ in stainless steel in the high flux region. Nickel-63 decays by emission of a relatively low, energy beta with a $66 \mathrm{KeV}$ endpoint energy. Bremsstrahlung production is thus negligible for this isotope.

$$
2.2 .2 .5 \quad{ }^{99} \mathrm{TC}
$$

Technetium-99 is normally considered in most reactor contexts as a fission product since the mass 99 isobar is essentially at the low mass peak of the $235 \mathrm{u}$ fission yield curve at $6.1 \%$ abundance. It is a major source of concern 
from a standpoint of nuclear waste disposal due to its long half-life $(213,000 \mathrm{y})$ and its potentially high environmental mobility. Its detection and identification is also a bit difficult. Technetium-99 can be produced as an activation product as well by neutron capture on $24 \%$ abundant 98 Mo to produce $66 \mathrm{~h} 99$ Mo. Molybdenum-99 in turn decays to the much longer-1ived ${ }^{99} \mathrm{Tc}$. The neutron capture cross-section of 0.14 barns and resonance integral of 6.6 barns are small but significant since molybdenum like nickel, is a major constituent of the stainless steel used in reactor internals in the high flux region. Technetium-99 decays by emission of a beta with a $298 \mathrm{KeV}$ endpoint energy.

\subsubsection{Other Beta Emitters}

In addition to the isotopes specifically discussed above, Table 1.1 contains a large number of other isotopes which are essentially pure beta

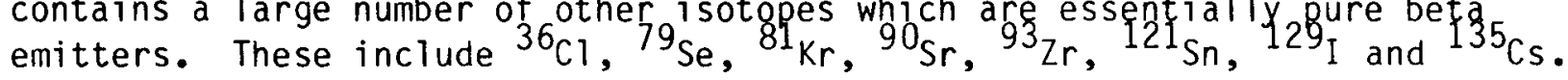
None of these are expected to be $g^{f}$ major importance as activation products although, as was the case with ${ }^{137} \mathrm{Cs},{ }^{90} \mathrm{Sr}$ will be present in some materials due to transiocation effects from ruptured fuel and is of major importance due to its relatively high biohazard potential.

\subsubsection{Eleciron Capture Isotopes}

A number of activation products decay by capture of orbital eiectrons to isotopes of atomic number Z-1. A few of these deserve special discussion due to their unusual properties.

\section{$2.2 .3 .1 \quad 59_{\mathrm{Ni}}$}

Nickel-59 is certainly one of the most important activation products with extremely long half-life $(80,000 \mathrm{y})$. It can be produced by a variety of mechanisms, however, the most important overwhelmingly is thermal neutron capture on $68.3 \%$ abundant $58 \mathrm{Ni}$. The high abundance of the target isotope, the large amounts of nickel present in reactor internals, and the moderately high production cross-section ( 4.6 barns) combine to produce ${ }^{59} \mathrm{Ni}$ in abundance particularly in reactor internals. Nickel-59 decays purely by electron capture $100 \%$ of the time to the ground state of ${ }^{59} \mathrm{Co}$. These decays are accompanied by low energy $X$-rays and electrons characteristic of cobalt. Most of the transition energy is carried away by a mono-energetic neutrino. In a very small percentage of decays in the electron capture process, the transition energy is divided between a gamma ray and neutrino, a process known as inner bremsstrahlung. Normally that branch is very minor. Nickel-59 has the unusual property of having an exceptionally high transition energy for its half life, $1.07 \mathrm{MeV}$. The total number of quanta per electron capture disintegration due to inner-bremsstrahlung is approximately $7.4 \times 10^{-4} E^{2}$ where $E$ is the transition energy in MeV. Nickel-59 thus produces a continuous spectrum of gamma rays up to $1.07 \mathrm{MeV}$ energy about one in every thousand decays. Due to 
its rather substantial production rate in all parts of the inner containment, ${ }^{59} \mathrm{Ni}$ is thus one of the limiting isotopes for dose considerations after decay of other shorter-lived residual activity has occurred.

\subsubsection{2 $93_{\mathrm{Mo}}$}

Molybdenum-93 is of special interest due to the presence of large amounts of molybdenum in reactor internals. Its half-life is thought to be around 3500 years, but is poorly known. Molybdenum-93 has the unusual property that it is produced primarily by epithermal neutron capture. Since the neutron shell of the target, $14.8 \%$ abundant $92 \mathrm{Mo}$, is closed at 50 neutrons, its thermal capture cross-section is very low ( 0.02 barns). The resonance integral of 0.81 barns is also moderately low. It can also be produced by $\mathrm{N}-2 \mathrm{~N}$ on $9.3 \%$ abundant $94 \mathrm{Mo}$. Since the threshold for this reaction is nearly $10 \mathrm{MeV}$ it also has a rather low yield. Molybdenum-93 is thus likely to be of less significance as an activation product than originally anticipated. It decays greater than $90 \%$ of the time to a $30.4 \mathrm{KeV}$ level of ${ }^{93} \mathrm{Nb}$. That level is itself a longlived activation product, $93 \mathrm{~m}_{\mathrm{Nb}}$, which decays to the ground state by internal transition with a 13.6 y half-life.

\subsubsection{3 $\stackrel{41}{ } \mathrm{Ca}$}

Calcium-41 is of particular interest due to its long physical and biological half-life. Bioshield concrete contains extremely high levels of calcium. Calcium-41 is thus likely to dominate the long-term disposal considerations with respect to bioshield concretes, the most voluminous activated component of the reactor. Calcium-41 is produced entirely by thermal neutron capture on $96.9 \%$ abundant ${ }^{40} \mathrm{Ca}$. Since the target nucleus is doubly magic in neutron and proton number (twenty each) its neutron capture cross-section is not very large ( 0.41 barns) and there are no important resonances. The production of ${ }^{41} \mathrm{Ca}$ in bioshield material is minimized by the relatively. low neutron flux escaping from the vessel in a LWR. Presumably, this situation would be somewhat worse for deuterium moderated or fast breeder designs. Calcium-41 decays purely to the ground state of $41_{K}$ with an approximate 103,000 year half-life. [The half-life is poorly known and is shown in various publications ranging from 80,000 to $130,000 \mathrm{y}$. In this work the half-life values as given in the Seventh Edition of the Table of Isotopes, (Browne, Dairiki, and Doebler 1978), have generally been adopted.] Its transition energy of $0.43 \mathrm{MeV}$ is carried away by the neutrino with inner bremsstrahlung of minimal importance. Decay energy available in the form of ionizing radiation amounts to only $3.6 \mathrm{KeV}$ mostly in the form of Auger electrons. According to the ICRP model, (ICRP 1959) however, calcium has a biological half-life of forty-four years and a fraction to the bone of greater than $50 \%$. This results in a rather low calculated MPCW for this isotope $\left(1.1 \times 10^{-4} \mathrm{mCi} / \mathrm{cm}^{3}\right)$. In spite of its low decay energy, the MPCW is considerably lower than that of 
${ }^{60} \mathrm{Co}$, for example. The problem is further complicated by the fact that this isotope has very unfavorable decay properties for routine detection at that level. The rather low specific activity found in PWR and BWR bioshield concrete does not appear to represent any significant biohazard. However, the hazard potential of this isotope is worth noting. Materials containing significant levels of calcium such as concrete should be carefully excluded from exposure to high neutron fluxes if possible.

\subsubsection{Other Electron Capture Isotopes}

Other isotopes shown in Table 1.1 decaying purely by ground state electron capture include $54 \mathrm{Mn}, 137 \mathrm{La}, 145 \mathrm{Pm}, 193 \mathrm{Pt}, 205 \mathrm{~Pb}$ and $208 \mathrm{Bi}$. These isotopes are expected to be of minor importance but are included for completeness.

\subsubsection{Alpha Emitters}

146 Seyęral iştopeşincluded in Table 1.1 decay by alpha emission, including ${ }^{146} \mathrm{Sm}, 233 \mathrm{U},{ }^{236} \mathrm{U},{ }^{237} \mathrm{~Np}$ and ${ }^{239} \mathrm{Pu}$. In general, yield $8 \mathrm{f}_{\text {g }}$ these isotopes should be very low with the possible exception of $239 \mathrm{Pu}$. The ${ }^{239} \mathrm{Pu}$ inventory of the reactor containment is in all probability dominated by other sources of $\mathrm{Pu}$ contamination unless the reactor operation is exceptionally clean and the concrete used is exceptionally high in uranium. 


\subsection{CONSTRUCTION MATERIALS}

\subsection{SOURCE OF SAMPLES}

Reference analytical samples of construction materials were solicited from a variety of sources. All utilities with reactors in the construction phase were contacted and requested to provide appropriately representative samples of bioshield materials and major reactor components. A total of 27 utilities representing 69 different construction projects were contacted. The actual yield of samples proved somewhat less than anticipated, but appears adequate for the goals of the program. Samples were also rather slow to arrive due to the complex organizational structure involved in a typical reactor construction project. An alternative source of samples was operating or shutdown reactors. These samples were taken during onsite visits on a related program. In addition to utility sources, steel samples were also made available through vessel surveillance programs. A selection of Type 304 and 316 stainless steel for nuclear use was also provided by the steel manufacturers.

\subsection{CONCRETE}

Concrete samples were obtained from 13 reactor sites with good geographical diversity. A full listing of the samples obtained is given in Table 3.1. Samples were either test pourings used for compressive strength testing or core samples taken with a $3 \mathrm{in}$. diamond coring bit. The samples were in several cases accompanied by matching ingredients for analysis in order to determine the origin of any unusually high concentrations of trace elements. The diversity of materials used is represented by the samples obtained. The coarse aggregate used in concrete manufacture at nuclear plants is generally typical of whatever rock can be quarried locally economically. The high costs associated with the use of high density aggregate has resulted in a far more limited use than was common in the early days of nuclear reactor development. Two samples of high density aggregate appearing to be illmenite and magnetite were provided from the Susquehanna Project. Several reactor projects are also using coal fly ash as an additive to their cement. Samples were obtained from the Enrico Fermi No. 2, Hartsville, Bellefonte and Palo Verde No. 2 projects. Since coal fly ash typically tends to concentrate some normally rare trace elements, these samples are of some interest.

\subsection{REBAR}

In this work rebar is estimated to comprise at least $10 \%$ by weight of the bioshield. In some newer reactors it may be considerably higher. The trace element composition of rebar is thus of some interest, particularly since the 
TABLE 3.1. Bioshield Materials (Unirradiated)

\begin{tabular}{|c|c|c|c|c|c|c|c|c|}
\hline Reactor & Type & Rebar & Concrete & Cement & $\underline{\text { Sand }}$ & $\begin{array}{l}\text { Fly } \\
\text { Ash }\end{array}$ & $\begin{array}{c}\text { High } \\
\text { Density } \\
\text { Aggregate } \\
\end{array}$ & $\begin{array}{l}\text { Ordinary } \\
\text { Aggregate }\end{array}$ \\
\hline Palo Verde No. 2 & PWR & 6 & 2 & 1 & 1 & 1 & & 2 \\
\hline Enrico Fermi No. 2 & BWR & 4 & 2 & 1 & 1 & 1 & & \\
\hline Wolf Creek & PWR & 10 & 3 & 1 & 1 & & & 2 \\
\hline Susquehanna & BWR & 1 & & 1 & 1 & & 2 & 1 \\
\hline Hartsville & BWR & & 2 & 1 & 1 & 1 & & 3 \\
\hline Bellefonte & PWR & 4 & 4 & 1 & 1 & 1 & & 3 \\
\hline Rancho Seco & PWR & 1 & 1 & & & & & \\
\hline Pathfinder & PWR & & 3 & & & & & \\
\hline WPPSS No. 1 & PWR & 4 & 4 & 1 & 2 & & & 4 \\
\hline Turkey Point No. 4 & PWR & & 2 & & & & & \\
\hline Humboldt Bay & BWR & & 4 & & & & & \\
\hline Waterford No. 3 & PWR & 3 & 2 & & 1 & & & 2 \\
\hline
\end{tabular}

\subsection{CARBON STEEL}

Samples of carbon steel used for vessel wall fabrication were obtained from several sources. These samples are in general Charpy impact specimens used for vessel surveillance programs. In several cases matching irradiated samples were also available.

\subsection{STAINLESS STEEL}

A selection of stainless steel was obtained from several sources. Most reactor internals are constructed of Type $304 \mathrm{~L}$ stainless steel with occasional use of 316 or Inconel for special purposes. 


\subsection{CONTROL RODS}

No attempt was made to obtain control rod material. Due to the nature of the material it would be a formidable analytical problem and very difficult to model from an activation standpoint. BWR control rods are composed of boron carbide. They should contain a substantial inventory of $10_{\mathrm{Be}}$ and ${ }^{14} \mathrm{C}$, as well as the isotopes associated with the stainless steel cladding. PWR control rods are a mixture of $\mathrm{Ag}, \mathrm{Cd}$, and In. The inventory of activation products in PWR control rods is thus likely to be largely dominated by 252 day $110 \mathrm{~m} A g$ in the short term and by 130 year $108 \mathrm{~m} \mathrm{Ag}$ on the longer time scale. It would be worthwhile determining these inventories empirically; however, the sampling and analysis of control rods was beyond the resources of this program.

\section{TABLE 3.2. Steel Samples (Unirradiated)}

\begin{tabular}{|c|c|c|c|c|c|}
\hline Supplier & $\begin{array}{l}\text { Vessel } \\
\text { Steel } \\
\end{array}$ & $\begin{array}{c}\text { Vessel } \\
\text { Cladding } \\
\end{array}$ & $\begin{array}{c}\text { Carbon } \\
\text { Steel } \\
\text { Internals } \\
\end{array}$ & $\begin{array}{c}\text { Stainless } \\
\text { Steel } \\
\text { Internals } \\
\end{array}$ & Incone 1 \\
\hline Enrico Fermi No. 2 & & & & 2 & \\
\hline Susquehanna & & & 1 & 1 & 1 \\
\hline Bellefonte & 1 & 1 & & & \\
\hline Northanna & & & & 1 & \\
\hline Pathfinder & & & & 1 & \\
\hline Battelle Columbus & 1 & & & & \\
\hline U.S. Steel & & & & 6 & \\
\hline Westinghouse & 8 & & & & \\
\hline Waterford No. 3 & & & & 1 & \\
\hline Turkey Point No. 3 & & & & 1 & \\
\hline
\end{tabular}




\subsection{CHEMICAL ANALYSIS PROGRAM}

\subsection{ANALYTICAL TECHNIQUES}

An analytical program was implemented to obtain information on up to 52 elements. The program relied mainly on two multielement instrumental methods; instrumental neutron activation (INAA) and energy dispersive $X$-ray fluorescence (XRF). The analytical procedures used are described below.

\subsubsection{Instrumental Neutron Activation Analysis (INAA)}

Sample Preparation

Geological material such as sand, cement, aggregate materials, and concretes were obtained for analysis from various reactor construction sites. Aliquots of each solid material were pulverized and ground to less than $150 \mu \mathrm{m}$ (100 mesh) using a Spex Shatterbox. The prepared samples were then stored in polyethylene bottles from which aliquots were taken for analysis by both INAA and XRF. Aliquots of 100 to $200 \mathrm{mg}$ were weighed into acid-cleaned $2 / 27 \mathrm{dram}$ polyvials for INAA analysis.

Metal construction materials such as rebar, stainless steels, and various other metal materials were prepared for analysis by machining. Aliquots of each metal material were taken as shavings or drill turnings. The samples were cleaned with alcohol, air dried, and stored in polyethylene bottles. Aliquots of 100 to $200 \mathrm{mg}$ for "longs" and $-500 \mathrm{mg}$ for "shorts" were then weighed into acid-cleaned $2 / 5$ dram polyvials for analysis by INAA.

\section{Sample Activation and Counting}

The strategy used for INAA analysis of these reactor construction materials involved two irradiations and five counting periods. The first, a short irradiation ("shorts"), was followed by two counts. The second irradiation was followed by three counts with an increasing decay time for each counting period. A summary of the nuclear properties involved is given in Tables 4.1 and 4.2. A thorough review of the procedures for INAA used in this laboratory and others is given by Laul (1979).

\section{Shorts Analysis}

Samples and standards were irradiated in the ${ }^{252} \mathrm{Cf}$-neutron multiplier facility of Pacific Northwest Laboratory. The samples were irradiated for 3 minutes at a flux of $\sim 2 \times 10^{9} \mathrm{n} \cdot \mathrm{cm}^{-2} \cdot \mathrm{s}^{-1}$. The irradiation and counting was controlled by a PDP $11 / 10$ computer which was part of a Tracor Northern computer-based data acquisition system (TN-11 system) (Wogman et al. 1978). 
TABLE 4.1. Production and Properties of the Nuclides Observed in a "Shorts" Irradiation

\begin{tabular}{|c|c|c|c|c|c|c|c|}
\hline Element & Reaction & $\begin{array}{l}\text { Isotopic } \\
\text { Abundance (\%) }\end{array}$ & $\begin{array}{c}\text { Cross-Section } \\
\text { (barns) } \\
\end{array}$ & $\begin{array}{l}\text { Half-Life } \\
\text { t } 1 / 2(\min ) \\
\end{array}$ & $\begin{array}{c}\text { Intensity } \\
\left(\gamma^{\prime} s \text { per } 100 \text { dis }\right) \\
\end{array}$ & $\begin{array}{l}\text { Major } r \text {-Rays } \\
(\mathrm{keV})\end{array}$ & Possible Interferences \\
\hline \multicolumn{8}{|c|}{ First Count } \\
\hline A1 & ${ }^{27} \mathrm{Al}(n, \gamma)^{28} \mathrm{Al}$ & 100 & 0.231 & 2.24 & 100 & 1778.7 & \multirow{5}{*}{$316.5\left({ }^{102}\right.$ I $\left.r\right), 3200\left({ }^{51} \mathrm{Cr}\right)$} \\
\hline $\mathrm{Ca}$ & ${ }^{48} \mathrm{Ca}(n, \gamma){ }^{49} \mathrm{Ca}$ & 0.187 & 1.1 & 8.719 & 92 & 3084.4 & \\
\hline $\mathrm{Ti}$. & ${ }^{50} T i(n, \gamma)^{51} T i$ & 5.2 & 0.179 & 5.80 & 93.4 & 319.7 & \\
\hline$v$ & ${ }^{51} V(n, y)^{52} V$ & 99.75 & 4.88 & 3.746 & 100 & 1423.06 & \\
\hline $\mathrm{Cu}$ & ${ }^{65} \mathrm{Cu}(n, y){ }^{66} \mathrm{Cu}$ & 30.8 & 2.17 & 5.10 & 8 & 1039.2 & \\
\hline \multicolumn{8}{|c|}{ Second Count } \\
\hline \multirow[t]{2}{*}{$\mathrm{Na}$} & ${ }^{23} \mathrm{Na}(\mathrm{n}, \mathrm{y})^{24} \mathrm{Na}$ & 100 & 0.53 & 901.2 & 100 & 1368.6 & \multirow{11}{*}{$841.5\left({ }^{152 m_{E u}}\right), 843.8\left({ }^{27} \mathrm{Mg}\right)$} \\
\hline & & & & & 100 & 2754.1 & \\
\hline \multirow[t]{2}{*}{$\mathrm{Cl}$} & ${ }^{37} \mathrm{Cl}(\mathrm{n}, \gamma){ }^{38} \mathrm{Cl}$ & 24.23 & 0.428 & 37.29 & 31. & 1642.2 & \\
\hline & & & & & 42 & 2167.6 & \\
\hline $\mathrm{K}$ & ${ }^{41_{K}} k(n, \gamma)^{42_{k}}$ & 6.71 & 1.46 & 741.7 & 18.8 & 1524.6 & \\
\hline \multirow[t]{3}{*}{ Mn } & ${ }^{55_{M n}(n, y)}{ }^{36} M n$ & 100 & 13.3 & 154.7 & 98.87 & 846.7 & \\
\hline & & & & & 27.2 & 1810.7 & \\
\hline & & & & & 14.3 & 2113.0 & \\
\hline Sr & ${ }^{86} S r(n, r)^{87 m} S r$ & 9.8 & 0.84 & 168.3 & 82 & 388.4 & \\
\hline$\dot{\mathrm{Ba}}$ & ${ }^{138} \mathrm{Ba}(n, \gamma)^{139} \mathrm{Ba}$ & 71.7 & 0.4 & 82.9 & 22 & 165.8 & \\
\hline Dy & ${ }^{164} \mathrm{Dy}(\mathrm{n}, \gamma)^{165} \mathrm{Dy}$ & 28.1 & 2700 & 140.0 & 3.58 & 94.7 & \\
\hline
\end{tabular}




\section{TABLE 4.2. Production and Properties of the Nuclides Observed in a "Long" Irradiation}

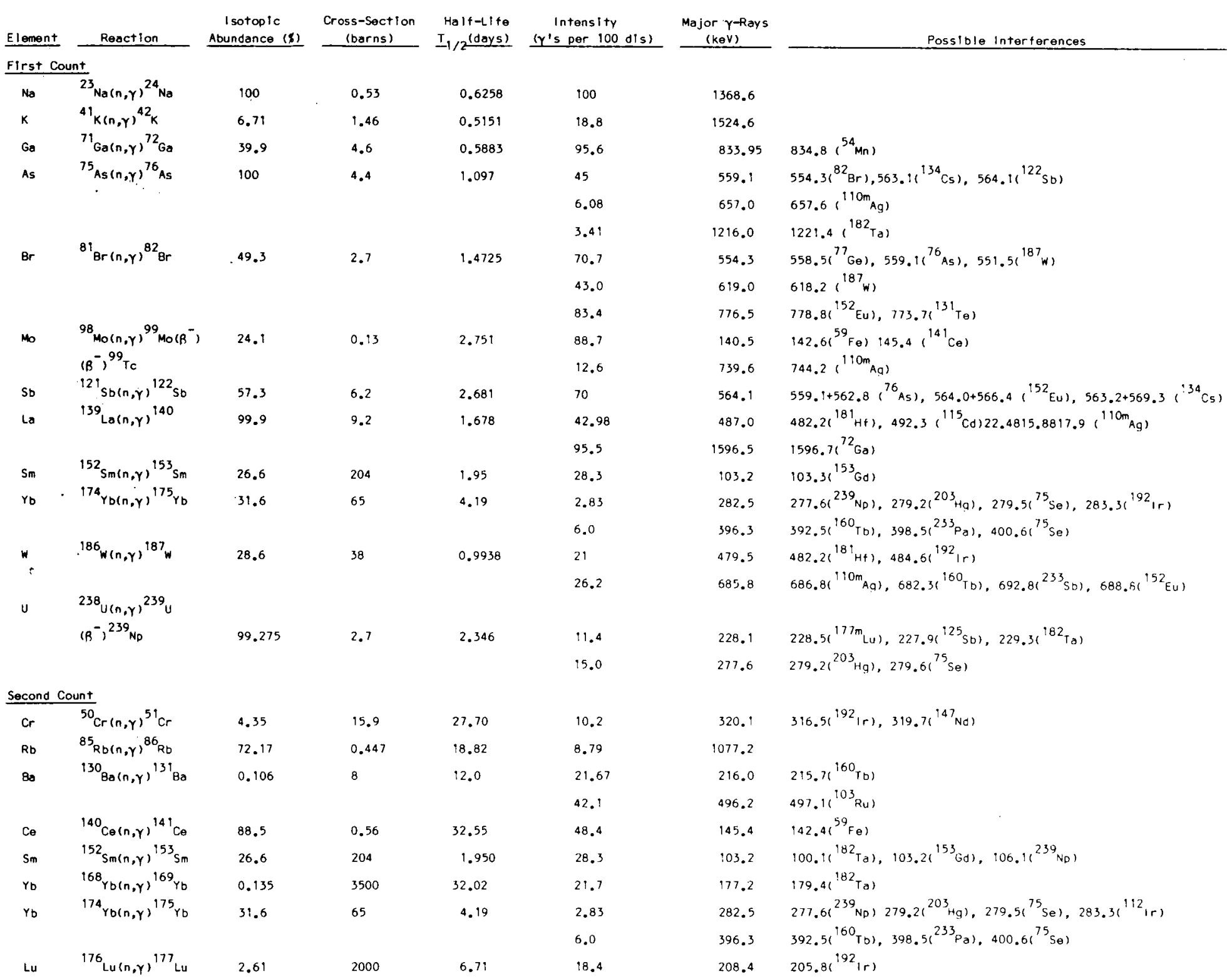




\section{TABLE 4.2. (contd)}

\begin{tabular}{|c|c|c|c|c|c|c|c|}
\hline Element & Reaction & $\begin{array}{c}\text { 1 sotoo /c } \\
\text { Abundance (x) }\end{array}$ & $\begin{array}{c}\text { Cross-Section } \\
\text { (barns) } \\
\end{array}$ & $\begin{array}{l}\text { Holf-LIte } \\
I_{1 / 2 \text { (days) }}\end{array}$ & $\begin{array}{c}\text { Intensity } \\
\text { (y's por } 100 \mathrm{dls}) \\
\end{array}$ & $\begin{array}{c}\text { Major } \gamma \text {-Rays } \\
(\mathrm{keV})\end{array}$ & Possible Interferences \\
\hline \multicolumn{8}{|c|}{ Third Count } \\
\hline Sc & ${ }^{45} \operatorname{sc}(n, \gamma)^{46} s c$ & 100 & 26 & 83.80 & 100 & 889.2 & $884.77^{\left.110 m_{\mathrm{Ag}}\right)}$ \\
\hline \multirow[t]{2}{*}{$\mathrm{Cr}$} & ${ }^{50} \mathrm{Cr}(\mathrm{n}, \mathrm{r}){ }^{51} \mathrm{cr}$ & 4.35 & 15.9 & 27.70 & 100 & 1820.5 & $\left.1115.5 r^{65} \mathrm{Zn}\right), 1120(8 \mathrm{kgd}), 1121.3\left({ }^{182} \mathrm{To}\right)$ \\
\hline & & & & & 10.2 & 320.1 & $316.5\left({ }^{192} \mid r\right), 319.7\left(^{147} \mathrm{Nd}\right)$ \\
\hline \multirow[t]{2}{*}{ Fe } & ${ }^{58} \mathrm{Fe}(n, \gamma){ }^{59} \mathrm{Fe}$ & 0.29 & 1.14 & 44.56 & 56.5 & 1099.2 & $1102.9\left(^{160} T b\right)$ \\
\hline & & & & & 43.5 & 1291.6 & $\left.1289.1\left(^{182} \mathrm{~T}\right), 1292.0{ }^{152} \mathrm{Eu}\right)$ \\
\hline \multirow[t]{2}{*}{ co } & ${ }^{59} \mathrm{Co}(n, \gamma)^{60} \mathrm{Co}$ & 100 & 37 & 1925.5 & 100 & 1973.2 & $\left.3177.88^{160} T b\right)$ \\
\hline & & & & & 100 & 1332.5 & \\
\hline $\mathrm{NI}$ & ${ }^{58}{ }_{\mathrm{NI}(n, p)}{ }^{58} \mathrm{Co}$ & 68.3 & 4.6 & 70.78 & 99.4 & 810.8 & \\
\hline $2 n$ & ${ }^{64} Z_{n}(n, y)^{65} z_{n}$ & 48.6 & 0.78 & 244.0 & 50.75 & 1115.5 & $112.0\left(^{152} \mathrm{Eu}\right) 113.2\left(^{182} \mathrm{Ta}\right), 1115.2\left(^{160} \mathrm{~Tb}\right), 1120.5\left(^{46} \mathrm{SC}\right)$ \\
\hline \multirow[t]{2}{*}{ So } & ${ }^{74} \mathrm{Se}(n, Y){ }^{75} \mathrm{Se}$ & 8.7 & 52 & 118.4 & 54.0 & 136.0 & $133.0\left(^{18}\right)_{\mathrm{H})}, 133.5\left(^{131} \mathrm{Bo}\right), 136.3\left(^{18} 1_{\mathrm{HF}}, 136.21^{192}(\mathrm{r})\right.$ \\
\hline & & & & & 58.0 & 264.7 & $261.0\left(^{169} Y_{b}\right), 264.1\left(^{189} \mathrm{Ta}_{\mathrm{a}}\right)$ \\
\hline RD & $\left.{ }^{85_{\mathrm{Rb}}(n, y)}\right)^{86_{\mathrm{Rb}}}$ & 72.17 & 0.447 & 18.82 & 8.79 & 1077.2 & \\
\hline $\mathrm{Sr}$ & ${ }^{84} \mathrm{Sr}(n, \gamma)^{85} \mathrm{Sr}$ & 0.56 & 0.3 & 64.35 & 99.3 & 514.0 & 511.0 (AnnInilatlon peak) \\
\hline \multirow[t]{2}{*}{$2 r$} & ${ }^{94} \mathrm{Zr}(n, \gamma)^{95} \mathrm{Zr}$ & 17.4 & 0.055 & 63.98 & 43.1 & 724.2 & \\
\hline & & & & & 54.5 & 756.7 & \\
\hline \multirow[t]{3}{*}{ Ag } & ${ }^{109} \mathrm{Ag}(\mathrm{n}, \mathrm{Y})^{110 \mathrm{~m}_{\mathrm{Ag}}}$ & 48.7 & 4 & 252.2 & 94.4 & 657.8 & $656.5\left({ }^{152} \mathrm{Eu}\right), 661.6(\mathrm{Bkgd})$ \\
\hline & & & & & 72.8 & 884.7 & $884.5\left({ }^{192} \mid r\right), 889.3\left(^{46} \mathrm{Sc}\right)$ \\
\hline & & & & & 34.3 & 937.5 & \\
\hline sb & ${ }^{123} \mathrm{SB}(n, \gamma){ }^{124} \mathrm{Sb}$ & 42.7 & 4.0 & 60.20 & 49.0 & 169.10 & \\
\hline cs & ${ }^{133} \operatorname{Cs}(n, \gamma){ }^{134} \mathrm{Cs}$ & 100 & 27 & 753.1 & 85.44 & 795.8 & \\
\hline \multirow[t]{2}{*}{$\mathrm{Ba}$} & ${ }^{130} \mathrm{Ba}(n, \gamma){ }^{131} \mathrm{Bo}$ & 0.106 & 8 & 12.0 & 21.67 & 216.0 & $215.7\left({ }^{160} \mathrm{~Tb}\right)$ \\
\hline & & & & & 42.1 & 496.2 & $\left.497.1^{103} \mathrm{Ru}\right)$ \\
\hline $\mathrm{C}_{\boldsymbol{\theta}}$ & ${ }^{140} \operatorname{Ce}(n, \gamma){ }^{141} C_{\theta}$ & 88.5 & 0.56 & 32.55 & 48.4 & 145.4 & $142.4\left({ }^{59} \mathrm{Fe}\right)$ \\
\hline \multirow[t]{3}{*}{$E_{u}$} & ${ }^{\left.151_{E U(n, \gamma}\right)}{ }^{152_{E u}}$ & 47.9 & 5800 & 4821.2 & 14.3 & 964.0 & $962.3\left(^{160} \mathrm{~Tb}\right), 966.2\left(^{160} \mathrm{~Tb}\right)$ \\
\hline & & & & & 10.1 & 1085.8 & \\
\hline & & & & & 20.7 & 1408.1 & \\
\hline \multirow[t]{2}{*}{$T_{b}$} & ${ }^{159} \mathrm{Th}(n, \gamma){ }^{160} \mathrm{~Tb}$ & 100 & 23 & 72.1 & 4.0 & 215.7 & $216.0\left(^{133} \mathrm{Ba}\right.$ \\
\hline & & & & & 30.0 & 879.4 & \\
\hline ro & $\left.{ }^{168} 8_{Y b(n, Y)}\right)^{169} Y$ & 0.135 & 3500 & 32.02 & 21.7 & 177.2 & $179.4\left(^{182} \mathrm{Ta}\right)$ \\
\hline \multirow[t]{2}{*}{$\mathrm{H}+$} & ${ }^{180} \mathrm{Hf}(\mathrm{n}, \mathrm{Y})^{18} !_{\mathrm{Hf}}$ & 35.2 & 14 & 42.45 & 32.4 & 133.0 & $\left.130.5\left(^{169} \mathrm{YD}\right), 133.5\left(^{131} \mathrm{Ba}\right), 136.01^{75} 5 \theta\right)$ \\
\hline & & & & & 81 & 482.0 & \left.480.)^{131} \mathrm{Bo}\right), 484.6^{(192 / r)}$ \\
\hline \multirow[t]{2}{*}{ To } & ${ }^{181} \mathrm{Ta}(\mathrm{n}, \mathrm{y}){ }^{182} \mathrm{Ta}$ & 99.99 & 21 & 115.0 & 16.4 & 1189.0 & \\
\hline & & & & & 27.1 & 1221.4 & \\
\hline \multirow[t]{2}{*}{ th } & ${ }^{232} T h(n, y){ }^{233} T h$ & & & & & & \\
\hline & $\left(B^{-}\right)^{233} \mathrm{Th}$ & 100. & 7.4 & 26.95 & 37 & 311.9 & $307.7\left(^{169} \mathrm{rb}\right), 308.4\left(^{192} \mid \mathrm{r}\right), 309.6\left(^{160} \mathrm{~Tb}\right), 316.5\left(^{192} \mid \mathrm{r}\right)$ \\
\hline
\end{tabular}


The computer based $T N-11$ system operated a pneumatic transfer rabbit shuttle which by operator input and program control irradiated the sample for a set length of time, allowed the sample to decay for a set time, and counted the sample for a preset length of time. The cycle was then repeated as many times as necessary. In particular, after a 3-min irradiation, the sample was allowed to decay for 5-min whereupon a 5-min count was initiated. Additionally, a 30 minute decay was also observed before a count of 30-min was initiated.

The detector system consisted of $2 \mathrm{Ge}(\mathrm{Li})$ diodes of $105 \mathrm{~cm}^{3}$ and $110 \mathrm{~cm}^{3}$ volume in an opposed geometry resulting in an exceptionally high counting efficiency. Acid-cleaned polyvials were used to contain the sample and as spacers in the acid-cleaned rabbit tube. Data was stored on floppy disks for subsequent data reduction.

\section{Longs Analysis}

Sampless and standards were irradiated for 7 hours at a flux of $1 x$ $10^{12} \mathrm{n} \cdot \mathrm{cm}^{-2} \cdot \mathrm{s}^{-1}$ in the rotating rack (lazy susan) of the $250 \mathrm{~kW}$ Triga reactor operated by Westinghouse-Hanford. The samples and standards were returned to the laboratory and repackaged in clean polyvials for counting on several high efficiency germanium diodes. The activated samples and standards were counted three times following delays of 3,7 , and 25 days. The data was collected on 4096 channel analyzers which were interfaced to a PDP 11/44 computer. The computer was used both for data manipulation and storage, as well as final data reduction.

\section{Data Reduction}

The spectral data was reduced with the use of a PDP 11/44 computer and the program CANGAS (Laul, Wilkerson and Crowe 1978). This program uses an operator created library with the parametric information necessary for each nuclide peak sought (see Table 4.1, and 4.2). The sample specific activity was then compared to the standard specific activity to obtain concentrations in $\mu \mathrm{g} / \mathrm{g}$. Spectral interference corrections were also made through the use of the CANGAS program.

\section{Standard Results}

The following standards were analyzed to obtain specific activities for each nuclide peak and as a means of quality assurance:

NBS SRM 1633 Coal Fly Ash

NBS SRM 123C Stainless Steel

NBS SRM 1155 Stainless Steel

IAEA So i $1-5$

USGS BHV0-1, Hawaiian Basalt 
USGS PCC-1, Peridotite, and

Various single element standards ( $\mathrm{Zn}, \mathrm{U}$, Mo and $\mathrm{Ag}$ )

Table 4.3 shows the average result obtained by the "shorts" analysis of" NBS 1633 fly ash, NBS 123 c stainless steel, and NBS 1155 stainless steel. Table 4.4 shows the average result obtained for the "1ongs" analysis of NBS $1633 \mathrm{fly}$ ash, NBS $123 \mathrm{C}$ stainless steel, NBS 1155 stainless steel, IAEA soil-5, USGS BHV0-1, and USGS PCC. There is excellent agreement between the average of the experimental results for "shorts" and "longs" with the recommended or best values.

\subsubsection{X-ray Fluorescence Analysis (XRF)}

The $X$-ray fluorescence procedure utilized in this work is a rather highly automated multielement technique capable of producing a rather large amount of high quality information on a short time scale at relatively minimal cost. It is applicable to a wide range of sample types including geological materials, waters, oils, metals, biological materials, glasses, etc. In most cases sample analysis proved to be a routine matter. A modest level of technique development was required for cement samples due to their very high calcium levels. A modification of the fundamental parameters data reduction code was also required for the steels analysis particularly for the highly radioactive samples (Nielson, Sanders, and Evans 1982).

Sample Preparation

Sample preparation for XRF is a relatively simple matter. Samples were initially treated as described in Section 4.1.1. Powdered samples were then pressed into $500 \mathrm{mg}$ pellets and mounted in $35 \mathrm{~mm}$ slide holders. Steel samples in the form of shavings or turnings were sandwiched between 0.1 mil polypropylene films on $35 \mathrm{~mm}$ slide holder mounts. In a few cases steel discs were also machined for comparison with the turnings. In general equivalent results were obtained and the simpler steel turnings method was adopted for all other samples. This comparison is described in more detail in Nielson, Sanders and Evans (1982).

\section{Analytical Procedure}

Three energy dispersive $X$-ray fluorescence systems were utilized in this work. For elements with low and intermediate atomic numbers a pair of secondary source systems manufactured by Kevex were used. The two systems, employing $60 \mathrm{kV}$ and $80 \mathrm{kV} X$-ray tubes respectively are normally used for three separate runs with $\mathrm{Ti}, \mathrm{Zr}$, and $\mathrm{Ag}$ secondary sources producing characteristic radiation to fluoresce the sample. A fourth bombardment with low energy gamma rays from a $241_{\text {Am }}$ isotopic source is used for elements with higher atomic numbers such as Ba. This system was developed in-house and shares data acquisition and 
TABLE 4.3. Comparison of Experimental and Reported Standard Values for "shorts" Analysis Element $\frac{\text { NBS } 1633 \text { Coal Fly Ash }}{\text { Expt. }} \frac{\text { NBS } 123 C \text { Steel }}{\text { (19 Samples) }} \frac{\text { Reported }}{(a)} \frac{\text { Expt. }}{\text { (5 Samples) }} \frac{\text { Reported }}{(b)} \frac{\text { NBS } 1155 \text { Steel }}{\frac{\text { Expt. }}{\text { (6 Samples) }}}$

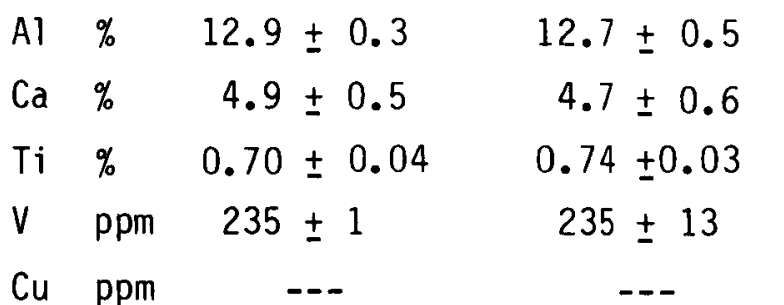

$$
0.049 \pm 0.007
$$

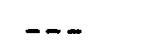

$0.022 \pm 0.004$
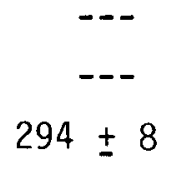

$1160 \pm 150$

$-\cdot$

(1)

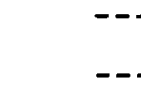

-..

$$
472 \pm 14
$$

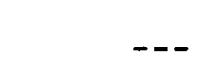

Cl ppm $44 \pm 9$ (14) $42 \pm 10$

K $\% \quad 1.7 \pm 0.3(13) \quad 1.61 \pm 0.15$

Mn ppm $497 \pm 22(17) \quad 496 \pm 19$

Sr ppm $1350 \pm 140(15) \quad 1700 \pm 200$

Ba ppm $2740 \pm 120(15) \quad 2700 \pm 200$

Dy ppm $8.9 \pm 0.5(15) \quad 8.8 \pm 2.3^{(c)}$

--
---
$-\cdots$
$-\cdots$
--
--

(a) Data taken from Ondov et al. (1975).

(b) Data taken from NBS Standard Certificates.

(c) Data taken from Gladney (1980). 
TABLE 4.4. Comparison of Experimental and Reported Standard Values for "Longs" Analysis

\begin{tabular}{|c|c|c|c|c|c|c|c|c|c|c|c|c|}
\hline \multirow{2}{*}{ Element } & \multicolumn{2}{|c|}{ NBS 1633 Fiy Ash } & \multicolumn{2}{|c|}{ IAEA SOII-S } & \multicolumn{2}{|c|}{ EHVO } & \multicolumn{2}{|l|}{$P C C-1$} & \multicolumn{2}{|c|}{ NoS $5+a a 1 \quad 123 c$} & \multicolumn{2}{|c|}{ NeS Stool 1155} \\
\hline & Expt. & Reported ${ }^{(0)}$ & Expt. & Roportad $(c)$ & Expt. & Reported ${ }^{(d)}$ & Expt. & Reporteg $(\theta)$ & Expt. & Reported ${ }^{(t)}$ & Expt. & Reportod $(t)$ \\
\hline & (A Somples) & & (3) Somples) & & (5 Samples) & & (4 Samoles) & & (4 Samples) & & (4 Samples) & \\
\hline Ne (DPm) & $3190 \pm 70$ & $3200 \pm 380$ & $18900 \pm 500$ & 18800 & $\$ 7100 \pm 500$ & $16400 \pm 600$ & & 50 & --- & --- & $\cdots$ & --- \\
\hline K (ppm) & $17000 \pm 600$ & $17000 \pm 900$ & $18300 \pm 1500$ & $19800 \pm 1000$ & $4600+200$ & $4600 \pm 700$ & & 30 & $\cdots$ & $-\cdots$ & -.- & $\ldots$ \\
\hline Co (ppm) & $49000 \pm 4000$ & $46000: 4000$ & $28000 \pm 500$ & $25000 \pm 4000$ & $81000 \pm 7000$ & $81800 \pm 1500$ & $3600 \pm 900$ & 3600 & --- & $\ldots$ & $\cdots$ & - \\
\hline Sc $1 \mathrm{ppm}$ & $26 \pm 1$ & $26 \pm 2$ & $13 \pm 1$ & $15.3 \pm 0.3$ & $30 \neq 2$ & $30 \pm 2$ & $7.5 \pm 0.3$ & 6.9 & --- & $\ldots$ & --- & -.- \\
\hline$G(\mathrm{ppm})$ & $128 \pm 1$ & $129 \pm 11$ & $28 \pm 3$ & $31 \pm 4$ & $290 \div 20$ & $290 \pm 30$ & $2670 \pm 160$ & 2730 & $164000 \pm 17000$ & 174000 & $191000 \pm 5000$ & 184000 \\
\hline Fe (ppm) & $63000 \pm 3000$ & $62000 \pm 4000$ & $44300 \pm 900$ & $48000 \pm 1000$ & $86000 \pm 2000$ & $85100 \pm 1900$ & $56700 \pm 1700$ & 58400 & $660000 \pm 40000$ & -- & $655000 \pm 25000$ & -- \\
\hline$C_{0}(p p m)$ & $40 \pm 2$ & $41.5 \pm 1.2^{(b)}$ & $13.5 \pm 0.8$ & $14.6 \pm 0.3$ & $44 \div 2$ & $45 \pm 2$ & $131 \pm 0$ & 112 & $1210 \pm 80$ & 1200 & $1080 \pm 30$ & 1000 \\
\hline NI (ppm) & $133 \pm 30$ & $98 \pm 11$ & $35 \pm 15$ & $<10$ & $130 \pm 20$ & $120 \pm 16$ & $2120 \pm 120$ & 2340 & $106000 \pm 9200$ & 113000 & $119000 \pm 10000$ & 121000 \\
\hline Gu (pPm) & - & $127 \div 8$ & -- & - & --- & $130 \pm 13$ & $\ldots$ & --- & $1030 \pm 260$ & 1030 & $1420 \pm 80$ & 1690 \\
\hline Zn (DPm) & $200 \pm 20$ & $213 \pm 13$ & $340 \pm 30$ & $400 \pm 40$ & $140 \pm 20$ & $102 \pm 8$ & $57 \pm 9$ & 36 & $104 \pm 24$ & $\ldots$ & --- & --- \\
\hline Go (ppm) & $46 \pm 7$ & $49 \pm 14$ & $28 \pm 3(2)$ & --- & --. & $22 \pm 3$ & -.- & --- & -- & --- & -- & -- \\
\hline As (ppm) & $57 \pm 4$ & $58 \pm 4^{(0)}$ & $94 \pm 8$ & $110 \pm 5$ & --- & --. & -.. & $\ldots$ & $57 \pm 4$ & --- & $99 \pm 9$ & $\ldots$ \\
\hline So (pDm) & $9.5 \pm 0.5$ & $9.6 \pm 0.8$ & $2.5 \pm 0.1(2)$ & $2.0 \pm 0.2$ & --- & --- & --- & --- & --- & -.- & -- & -.. \\
\hline Br $\quad(\mathrm{DPm})$ & $12.1 \pm 0.3$ & $12 \pm 4^{(0)}$ & $10.4 \pm 0.4$ & $6.8 \pm 0.5$ & -- & -.- & $0.73 \pm 0.05$ & -.. & --- & --- & $\ldots$ & --- \\
\hline Ro (DPM) & $115 \pm 4$ & $114 \pm 10$ & $117 \pm 4$ & $140 \pm 20$ & $16 \pm 3$ & $\cdots$ & --- & 0.063 & --- & --- & -- & $\cdots$ \\
\hline Sr (DPm) & $1400 \pm 60(6)$ & $1380 \pm 190$ & $390 \pm 40$ & $400 \pm 50$ & $420 \pm 40$ & $440 \pm 70$ & -- & 0.4 & -- & --- & -- & $\cdots$ \\
\hline $\operatorname{Zr}(\mathrm{ppm})$ & $290 \pm 20$ & $300 \pm 75$ & $170 \pm 20$ & $240 \pm 20$ & $140 \pm 20$ & $177 \pm 26$ & --- & $0.7(7)$ & --- & -- & -- & -- \\
\hline Mo (ppm) & $\ldots$ & $29 \pm 5$ & -- & --. & -.. & --- & --- & -.- & $2200 \pm 200$ & 2200 & $22000 \pm 2000$ & 23800 \\
\hline$A g(D P M)$ & --- & --- & -- & --- & --- & -.- & --- & --- & --- & --- & - & $\cdots$ \\
\hline SO (DDM) & $6.8 \pm 0.3$ & $6.9 \pm 0.4$ & $14.5 \pm 0.5$ & $14.7 \pm 0.4$ & $0.23 \pm 0.07$ & $0.17 \pm 0.01$ & $3.5 \pm 0.1$ & 1.4 & $8.5 \pm 1.4$ & -.. & $19 \pm 4$ & --- \\
\hline Cs (ppm) & $8.5 \pm 0.5$ & $8.6 \pm 1.8$ & $51 \pm 2$ & $50 \pm 5$ & $0.18 \pm 0.02$ & -.- & --- & 0.006 & --- & ... & --- & -- \\
\hline Bo (ppm) & $2800 \pm 120$ & $2700 \pm 170$ & $650 \pm 60$ & $550 \pm 40$ & $260 \pm 60$ & $143 \pm 20$ & -.- & -.. & ... & & & \\
\hline Lo (ppm) & $78 \pm 2(7)$ & $79 \pm 7$ & $28.4 \pm 0.8$ & $30 \pm 1$ & $16.6 \pm 0.9$ & $16.7 \pm 0.8$ & $\ldots$ & 0.15 & -.. & $\ldots$ & -- & $\therefore-$ \\
\hline$C_{\theta}(\mathrm{ppm})$ & $145 \pm 8$ & $146 \pm 15^{(0)}$ & $51 \pm 2$ & $59 \pm 2$ & $38 \pm 1$ & $40 \pm 4$ & --- & 0.09 & -.- & -.- & -.. & $\ldots$ \\
\hline$S_{m}$ (ppm) & $12.3 \pm 0.5$ & $12.4 \pm 1.1$ & $4.8 \pm 0.2$ & $5.60 \pm 0.04$ & $9.5 \pm 0.4$ & $6.2 \pm 0.7$ & --. & 0.008 & --- & --- & $\ldots$ & ... \\
\hline Eu (ppm) & $2.6 \pm 0.1$ & $2.6 \pm 0.2$ & $1.07 \pm 0.07$ & $1.15 \pm 0.05$ & $2.0 \pm 0.1$ & $2.1 \pm 0.4$ & $0.0086 \pm 0.0007$ & $7 \quad 0.002$ & -.- & -.- & $\ldots$ & -.- \\
\hline To (DDm) & $2.1 \pm 0.1$ & $2.1 \pm 0.6$ & $0.76 \pm 0.05$ & $0.70 \neq 0.03$ & $1.11 \pm 0.07$ & $1.0 \pm 0.3$ & -- & 0.001 & -- &.-- & -- & -- \\
\hline ro (ppm) & $6.4 \pm 0.2$ & $6.4 \pm 1.1$ & $2.4 \pm 0.1$ & $2.3 \pm 0.1$ & $2.3 \pm 0.1$ & $2.1 \pm 0.5$ & -.. & 0.02 & -.. & -.. & ... & ... \\
\hline Lu (ppm) & $1.51 \pm 0.04$ & $1.5 \pm 1.2$ & $0.55 \pm 0.04$ & $0.37 \pm 0.03$ & $0.43 \pm 0.01$ & -- & --- & 0.006 & -- & $\cdots$ & -- & $\cdots$ \\
\hline Hi (ppm) & $7.6 \pm 0.5$ & $7.8 \pm 1.1$ & $6.5 \pm 0.6$ & $6.5 \pm 0.2$ & $4.8 \pm 0.1$ & $4.1 \pm 0.3$ & --- & 0.06 & $\cdots$ & -- & $\cdots$ & --- \\
\hline To (DPm) & $2.2 \pm 0.1$ & $2.2 \pm 0.5$ & $0.83 \pm 0.05$ & $0.76 \pm 0.05$ & $1.38 \pm 0.06$ & $1.08 \pm 0.18$ & -.- & $<0.1$ & $5.9 \pm 0.5$ & --- & - & -- \\
\hline$N(p D m)$ & $5.5 \pm 0.4$ & $5.5 \pm 2.6$ & $6.4 \pm 0.5$ & $\ldots$ & $1.3 \pm 0.3$ & -.- & --- & -.. & $92 \pm 11$ & --- & $1040 \pm 160$ & ... \\
\hline Th $(\mathrm{ppm})$ & $25 \pm 1$ & $25 \pm 1$ & $n \pm 1$ & $10.9 \pm 0.6$ & $1.23 \pm 0.07$ & $1.0 \pm 0.2$ & -.- & 0.01 & --- & -.. & --- & -. \\
\hline$v$ (ppm) & $14 \pm 2$ & $11.4 \pm 1.4$ & $3.8 \pm 0.8$ & --. & $0.58 \pm 0.10$ & $0.40 \pm 0.06$ & --- & --- & $\ldots$ & -.. & $\ldots$ & --. \\
\hline
\end{tabular}


reduction with the two Kevex systems. Data acquisition utilizes a Canberra System 80 multichannel analyzer with multiple analog to digital converters interfaced to a DEC PDP $11 / 34$ computer. All data reduction is done on line by the PDP 11/34. A fundamental parameter method is used which utilizes coherent to incoherent peak scattering ratios to calculate the absorption properties of the matrix. The program (SAP3) makes peak overlap corrections, grain size corrections, self-absorption corrections, etc. These results are then reconciled against a library of thin film standards to calculate a final result. The SAP3 program has undergone continual improvement and upgrading. A description of the most recent version of this work is given by Nielson and Sanders (1982).

\section{Standard Results}

In order to verify the accuracy of the method quality assurance samples of standard reference materials are run periodically. Tables 4.5 and 4.6 show comparisons with accepted values for NBS steel and NBS fly ash standards. In general, agreement is excellent.

TABLE 4.5. Comparison of Experimental and Reported Values for XRF Analysis of Steel

\begin{tabular}{|c|c|c|}
\hline Element & $\begin{array}{l}\text { NBS } 1155 \text { Expt. } \\
\text { (4 samples) }\end{array}$ & Reported (a) \\
\hline $\mathrm{Ti}(\%)$ & $0.148 \pm 0.017$ & \\
\hline$V(p p m)$ & $456 \pm 86$ & 470 \\
\hline $\mathrm{Cr}(\%)$ & $18.1 \pm 0.05$ & 18.45 \\
\hline $\operatorname{Mn}(\%)$ & $1.76 \pm 0.063$ & 1.63 \\
\hline $\mathrm{Fe}(\%)$ & $64.83 \pm 0.096$ & 64.5 \\
\hline $\mathrm{Ni}(\%)$ & $12.1 \pm 0.082$ & 12.18 \\
\hline $\mathrm{Cu}(\%)$ & $0.158 \pm 0.0096$ & 0.169 \\
\hline $\operatorname{Zn}(p p m)$ & $200 \pm 62$ & \\
\hline As (ppm) & $108 \pm 21$ & \\
\hline $\mathrm{Br} \quad(\mathrm{ppm})$ & $<25$ & \\
\hline $\mathrm{Rb} \quad(\mathrm{ppm})$ & $<14$ & \\
\hline $\mathrm{Sr} \quad(\mathrm{ppm})$ & $<12$ & \\
\hline$Y(p p m)$ & $<11$ & \\
\hline $\mathrm{Zr} \quad(\mathrm{ppm})$ & $<11$ & \\
\hline $\mathrm{Nb} \quad(\mathrm{ppm})$ & $<14$ & \\
\hline Mo $(\%)$ & $2.22 \pm 0.019$ & 2.38 \\
\hline
\end{tabular}

(a) Data taken from NBS Certificate of Analysis. 
TABLE 4.6. Comparison of Experimental and Reported Values for XRF Analysis of Fly Ash

\begin{tabular}{|c|c|c|}
\hline Element & $\begin{array}{l}\text { NBS } 1633 A \text { Expt. } \\
\text { (4 samples) }\end{array}$ & Reported \\
\hline Al $(\%)$ & $15.9 \pm 1.3$ & $14.0 \pm 0.2$ \\
\hline Si $(\%)$ & $23.4 \pm 1.1$ & $22.8 \pm 0.80$ \\
\hline $\mathrm{S}(\%)$ & $0.342 \pm 0.013$ & $0.27 \pm 0.02$ \\
\hline$K(\%)$ & $1.88 \pm 0.018$ & $1.88 \pm 0.06$ \\
\hline $\mathrm{Ca}(\%)$ & $1.17 \pm 0.038$ & $1.11 \pm 0.01$ \\
\hline $\mathrm{Ti}(\%)$ & $0.816 \pm 0.026$ & $0.84 \pm 0.01$ \\
\hline$V(p p m)$ & $302 \pm 32$ & $300 \pm 40$ \\
\hline $\mathrm{Cr}$ (ppm) & $194 \pm 58$ & $196 \pm 6$ \\
\hline$M n$ (ppm) & $174 \pm 36$ & $190 \pm 15$ \\
\hline $\mathrm{Fe}(\%)$ & $9.53 \pm 0.29$ & $9.40 \pm 0.10$ \\
\hline $\mathrm{Ni}$ (ppm) & $139 \pm 11$ & $127 \pm 4$ \\
\hline $\mathrm{Cu}$ (ppm) & $122 \pm 15$ & $118 \pm 3$ \\
\hline $\mathrm{Zn} \quad(\mathrm{ppm})$ & $241 \pm 13$ & $220 \pm 10$ \\
\hline $\mathrm{Ga}(p p m)$ & $58 \pm 4$ & $58 \pm 6$ \\
\hline As (ppm) & $156 \pm 12$ & $145 \pm 15$ \\
\hline Se (ppm) & $10.0 \pm 1.7$ & $10.3 \pm 0.6$ \\
\hline $\mathrm{Rb} \quad(p p m)$ & $133 \pm 5$ & $131 \pm 2$ \\
\hline $\mathrm{Sr}$ (ppm) & $842 \pm 19$ & $830 \pm 30$ \\
\hline$Y(p p m)$ & $88 \pm 3$ & \\
\hline $\mathrm{Zr} \quad(p p m)$ & $239 \pm 5$ & \\
\hline $\mathrm{Nb} \quad(p p m)$ & $28.7 \pm 1.3$ & \\
\hline Mo (ppm) & $33.7 \pm 0.37$ & $29 \pm 3$ \\
\hline $\mathrm{Ba}(\mathrm{ppm})$ & $1642 \pm 199$ & $1500 \pm 200$ \\
\hline $\mathrm{Pb} \quad(\mathrm{ppm})$ & $73.9 \pm 5.05$ & $72.4 \pm 0.4$ \\
\hline
\end{tabular}

\subsubsection{Other Analytical Methods Used}

In a few selected cases specialized analytical procedures were utilized to add a limited amount of data to the total information base. These include flame atomic absorption for Li, graphite furnace atomic absorption for $\mathrm{Ag}$, and a combustion train method for nitrogen. A few samples were also sent to the National Bureau of Standards for analysis by prompt gamma activation analysis. 


\subsection{CHEMICAL ANALYSIS RESULTS}

\subsubsection{Stainless Steel}

Chemical analysis results for thirteen samples of nuclear grade Type 304L stainless steel are given in Table 4.7. This data is summarized in Table 4.8. As might be expected, elements involved in the alloy process control show very little variability. These include $\mathrm{Fe}, \mathrm{Cr}$, and $\mathrm{Ni}$. Activatible trace elements on the other hand show a surprisingly large variation. Of particular note is cobalt which shows a range of more than an order of magnitude with the average value about seven times higher than the lowest value. This suggests that had greater attention been given to process control and batch selection of steels prior to construction, a considerably reduced ${ }^{60} C_{0}$ inventory would result, thus both reducing translocation problems during operations and minimizing doses during dismantling. The niobium results showed a very wide variability. The two samples from the Enrico Fermi project from different heats were very low in niobium ( $<5 \mathrm{ppm}$ ) with other samples ranging up to 200 to $300 \mathrm{ppm}$, somewhat above the $160 \mathrm{ppm}$ now adopted by the steel manufacturers as an upper bound for nuclear grade steel. Several other activatible elements also showed marked variability including $\mathrm{Se}, \mathrm{Br}$, and $\mathrm{Mo}$. Europium was in general below detection limits for that matrix; however, at least one other more abundant rare earth, cerium was found at highly variable levels suggesting that there may be some Eu present also. The origin of these large variations in trace element concentration is a bit unclear. At least for some elements such as $\mathrm{Co}, \mathrm{Nb}$, and Mo, it may be in part due to cross contamination between batches of ordinary and specialty stainless steels produced in the same crucibles.

\subsubsection{Other Reactor Internals Steels}

Table 4.9 tabulates the chemical compositions of some steels used in a more limited application for reactor internals. The three Type 316 samples analyzed contained cobalt levels similar to the average for the 304 . They were relatively low in niobium but about ten times higher in molybdenum. The inconel samples were very high in niobium, particularly the Point Beach sample which contained about $5 \% \mathrm{Nb}$. This was an activated sample from the fuel support structure which did in fact contain a substantial level of ${ }^{94} \mathrm{Nb}$.

\subsubsection{Vessel Steels}

Table 4.10 lists the compositions of 10 vessel steels. The data is summarized in Table 4.11. Eight of the samples were received very late in the program and consequently were analyzed only using XRF. The Bellefonte sample is interesting in that it shows a small amount of europium present in spite of being very low in cerium, in contrast to some of the stainless steel samples. Carbon steel is in general rather low in cobalt. Variations in cobalt in 
TABLE 4.7. Chemical Analyses of Type 304 Stainless Steel

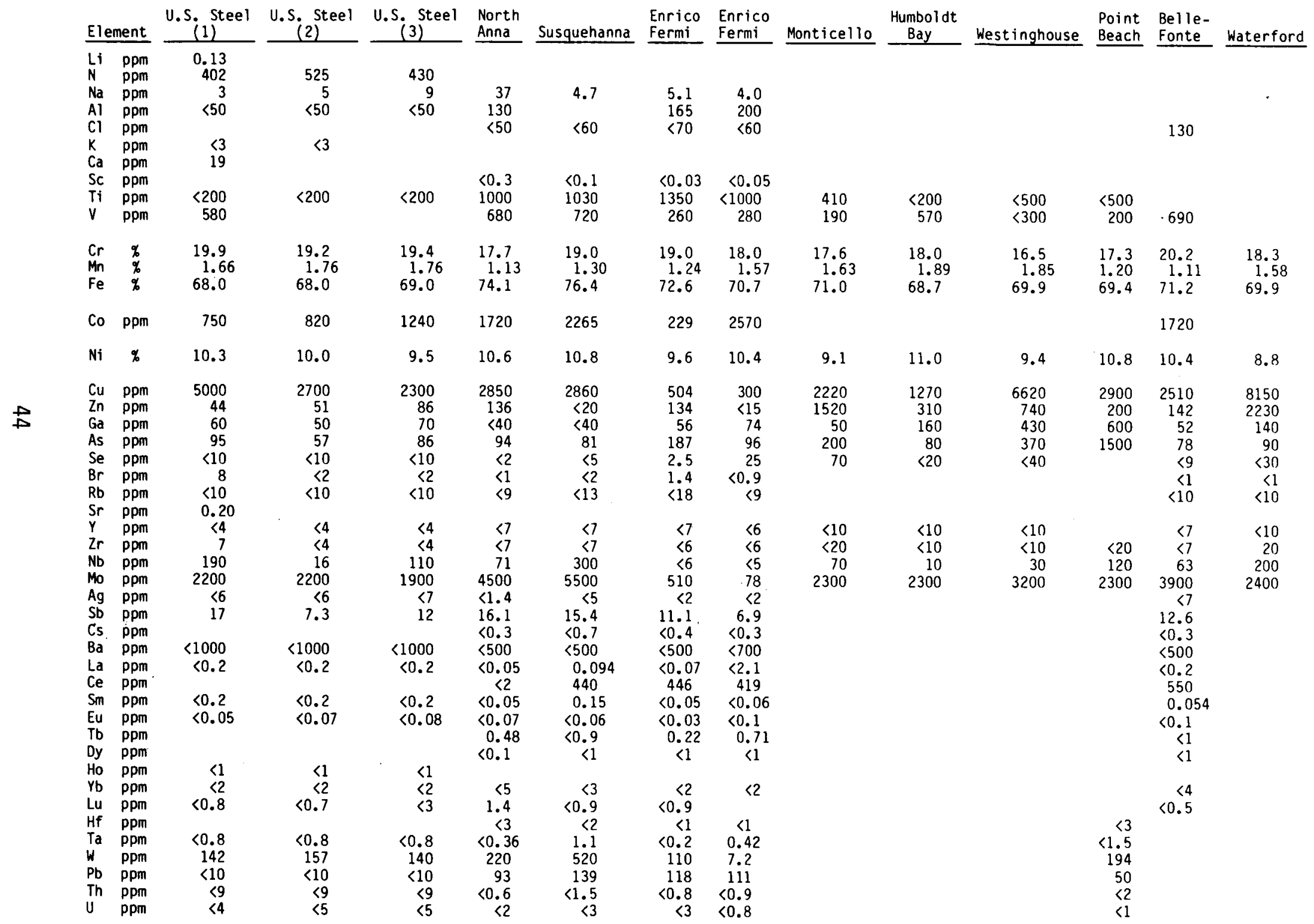


TABLE 4.8. Type 304 Stainless Steel Composition Summary

\begin{tabular}{|c|c|c|c|c|c|c|c|c|}
\hline \multicolumn{2}{|c|}{ Element } & Average & S.D. ${ }^{\%}(a)$ & \multicolumn{3}{|c|}{ Range } & $\begin{array}{r}\text { Range } \\
\text { Factor }(b)\end{array}$ & $\begin{array}{c}\text { No. of } \\
\text { Measurements } \\
\text { Used } \\
\end{array}$ \\
\hline $\operatorname{Li}$ & ppm & 0.13 & & & & & & $\frac{1}{2}$ \\
\hline $\begin{array}{l}\mathrm{N} \\
\mathrm{Na}\end{array}$ & ppm & $452 \pm 64$ & 14 & 402 & to & 525 & 1.3 & 3 \\
\hline $\begin{array}{l}\mathrm{Na} \\
\mathrm{Al}\end{array}$ & ppm & $9.7 \pm 12.2$ & 126 & 3 & to & 37 & 12.3 & 7 \\
\hline Al & $\mathrm{ppm}$ & $1 \overline{0} 0$ & & $<50$ & to & 200 & & 6 \\
\hline $\mathrm{Cl}$ & ppm & 70 & & $<50$ & to & 130 & & 5 \\
\hline$k$ & $\mathrm{ppm}$ & $<3$ & & & & & & 3 \\
\hline $\mathrm{Ca}$ & ppm & 19 & & & & & & 1 \\
\hline Sc & ppm & $<0.03$ & & & & & & 1 \\
\hline $\mathrm{Ti}$ & $\mathrm{ppm}$ & $<600$ & & & & & & 10 \\
\hline V & $\mathrm{ppm}$ & $456 \pm 235$ & 52 & 140 & to & 690 & 4.90 & 9 \\
\hline $\mathrm{Cr}$ & $\%$ & $18.4 \pm 1.1$ & 6 & 16.5 & to & 20.2 & .2 & 13 \\
\hline$M n$ & $\%$ & $1.53 \pm 0.27$ & 18 & 1.11 & to & 1.76 & 1.6 & 13 \\
\hline $\mathrm{Fe}$ & $\%$ & $70.6 \pm 2.6$ & 4 & 68.0 & to & 76.7 & 1.1 & 13 \\
\hline Co & $\mathrm{ppm}$ & $1414 \pm 800$ & 57 & 229 & to & 2570 & 11.2 & 8 \\
\hline $\mathrm{Ni}$ & $\%$ & $10.0 \pm 0.7$ & 7 & 8.8 & to & 11.0 & 1.3 & 13 \\
\hline $\mathrm{Cu}$ & $\mathrm{ppm}$ & $3080 \pm 2270$ & 74 & 300 & to & 8150 & 27.2 & 13 \\
\hline Zn & $\mathrm{ppm}$ & $457 \pm 717$ & 157 & $<15$ & to & 2230 & $>1.3$ & 12 \\
\hline Ga & $\mathrm{ppm}$ & $129 \pm 143$ & 90 & $<40$ & to & 450 & $>11.3$ & 13 \\
\hline As & $\mathrm{ppm}$ & $194 \pm 259$ & 168 & $<57$ & to & 1010 & $>17.7$ & 13 \\
\hline Se & $\mathrm{ppm}$ & $\approx \overline{3} 5$ & & $<2$ & to & 70 & $>35$ & 13 \\
\hline $\mathrm{Br}$ & $\mathrm{ppm}$ & $\sim 2$ & & $<0.9$ & to & 8.0 & 78.9 & 8 \\
\hline $\mathrm{Rb}$ & ppm & $<10$ & & & & & & 9 \\
\hline $\mathrm{Sr}$ & $\mathrm{ppm}$ & 0.2 & & & & & & 1 \\
\hline$Y$ & ppm & $<5$ & & & & & & 12 \\
\hline $\mathrm{Zr}$ & ppm & $\approx 10$ & & $<4$ & to & 20 & & 13 \\
\hline $\mathrm{Nb}$ & ppm & $89 \pm 90$ & 101 & $<5$ & to & 300 & $>60$ & 13 \\
\hline Mo & $\mathrm{ppm}$ & $02.600^{-} \pm 1500$ & 58 & 80 & to & 5500 & 68.8 & 13 \\
\hline $\mathrm{Ag}$ & $\mathrm{ppm}$ & $<\overline{2}$ & & & & & & 8 \\
\hline $\mathrm{Sb}$ & $\mathrm{ppm}$ & $12.3 \pm 3.8$ & 31 & 6.9 & to & 17.0 & 2.5 & 8 \\
\hline Cs & $\mathrm{ppm}$ & $<0.3$ & & & & & & 5 \\
\hline $\mathrm{Ba}$ & $\mathrm{ppm}$ & $<500$ & & & & & & 8 \\
\hline La & $\mathrm{ppm}$ & $\approx 0.2$ & & $<0.05$ & to & 2.1 & $>42.0$ & 8 \\
\hline $\mathrm{Ce}$ & ppm & $371 \pm 212$ & 57 & $<2$ & to & 550 & $>275.0$ & 8 \\
\hline Sm & $\mathrm{ppm}$ & $\approx 0.1$ & & $<0.05$ & to & 0.15 & $>3$ & 7 \\
\hline Eu & $\mathrm{ppm}$ & $\approx 0.02$ & & & & & & inferred \\
\hline $\mathrm{Tb}$ & $\mathrm{ppm}$ & $0.47 \pm 0.25$ & 53 & 0.22 & to & 0.71 & & 3 \\
\hline Dy & $\mathrm{ppm}$ & $<1$ & & & & & & 5 \\
\hline Ho & $\mathrm{ppm}$ & $<1$ & & & & & & 3 \\
\hline$Y b$ & $\mathrm{ppm}$ & $<2$ & & & & & & 5 \\
\hline Lu & ppm & $<0.8$ & & & & & & 7 \\
\hline $\mathrm{Hf}$ & ppm & $<2$ & & & & & & 3 \\
\hline W & $\mathrm{ppm}$ & $186 \pm 149$ & 80 & 7.2 & to & 520 & & 8 \\
\hline $\mathrm{Pb}$ & $\mathrm{ppm}$ & $67 \pm 50$ & 75 & $<10$ & to & 139 & $>13.9$ & 9 \\
\hline Th & $\mathrm{ppm}$ & $<1$ & & & & & & 3 \\
\hline U & $\mathrm{ppm}$ & $<2$ & & & & & & 3 \\
\hline
\end{tabular}

(a) Relative standard deviation expressed as a percentage of the average value.

(b) Range factor shown is the ratio of the highest to the lowest value measured. 
TABLE 4.9. Chemical Analysis of Steel Used for Reactor Internals

\begin{tabular}{|c|c|c|c|c|c|c|c|}
\hline \multicolumn{2}{|c|}{ Element } & $\begin{array}{c}\text { IJ.S. Steel } \\
\text { SS } 316 \\
\end{array}$ & $\begin{array}{c}\text { U.S. Steel } \\
\text { SS } 316 \\
\end{array}$ & $\begin{array}{l}\text { U.S. Steel } \\
\text { SS } 316 \\
\end{array}$ & $\begin{array}{c}\text { Susquehanna } \\
\text { Inconel } \\
\text { SB } 166 \\
\end{array}$ & $\begin{array}{c}\text { Point Beach } \\
\text { Inconel } \\
710 \\
\end{array}$ & $\begin{array}{c}\text { Susquehanna } \\
\text { SA } 508 \\
\end{array}$ \\
\hline$L_{N} i$ & $\begin{array}{l}\mathrm{ppm} \\
\mathrm{ppm}\end{array}$ & $\begin{array}{l}0.18 \\
357\end{array}$ & & & & . & \\
\hline $\mathrm{Na}$ & $\mathrm{ppm}$ & 5 & 6 & $<2$ & 4.1 & & 6.8 \\
\hline Al & $\mathrm{ppm}$ & $<50$ & & & 1160 & & 120 \\
\hline $\mathrm{Cl}$ & $\mathrm{ppm}$ & & & & 26 & & 63 \\
\hline K & $\mathrm{ppm}$ & $<3$ & & & $<60$ & & \\
\hline $\mathrm{Ca}$ & ppm & 14 & & & & & \\
\hline $\mathrm{Ti}$ & ppm & $<200$ & $<200$ & $<200$ & 2280 & & 690 \\
\hline V & $\mathrm{ppm}$ & 630 & & & 270 & & 121 \\
\hline $\mathrm{Cr}$ & $\%$ & 16.8 & 17.3 & 17.2 & 15.2 & 15.1 & 0.38 \\
\hline$M n$ & $\%$ & 1.30 & 1.30 & 1.52 & 0.23 & & 0.65 \\
\hline $\mathrm{Fe}$ & $\%$ & 65 & 65 & 64 & 9.96 & 17.5 & 115 \\
\hline Co & $\mathrm{ppm}$ & 1630 & 1340 & 1450 & 574 & & 115 \\
\hline $\mathrm{Ni}$ & $\%$ & 13.2 & 12.8 & 12.5 & 74.5 & 57.3 & 0.93 \\
\hline $\mathrm{Cu}$ & $\mathrm{ppm}$ & 2600 & 2900 & 2200 & 2240 & 450 & 1000 \\
\hline $\mathrm{Zn}$ & ppm & 71 & & & $<9$ & 2330 & $<9$ \\
\hline $\mathrm{Ga}$ & $\mathrm{ppm}$ & 60 & 50 & 60 & 13 & 40 & $<40$ \\
\hline As & $\mathrm{ppm}$ & 95 & 75 & 86 & 33 & & 96 \\
\hline Se & $\mathrm{ppm}$ & $<9$ & $<9$ & $<9$ & $<3$ & & $<1$ \\
\hline $\mathrm{Br}$ & $\mathrm{ppm}$ & $<2$ & $<2$ & $<2$ & $<0.7$ & & 16 \\
\hline $\mathrm{Rb}$ & $\mathrm{ppm}$ & & & & $<11$ & & 32 \\
\hline $\mathrm{Sr}$ & $\mathrm{ppm}$ & 0.23 & & & & & \\
\hline Y & $\mathrm{ppm}$ & $<5$ & $<5$ & $<5$ & $<11$ & & $<7$ \\
\hline $\mathrm{Zr}$ & $\mathrm{ppm}$ & 6 & 6 & $<6$ & $<8$ & & $<7$ \\
\hline $\mathrm{Nb}$ & $\mathrm{ppm}$ & 12 & 64 & 12 & 385 & 49600 & $<8$ \\
\hline Mo & $\%$ & 2.06 & 2.12 & 2.16 & 0.19 & 2.72 & 0.76 \\
\hline $\mathrm{Ag}$ & $\mathrm{ppm}$ & $<5$ & & & $<2$ & & $<6$ \\
\hline $\mathrm{Sb}$ & $\mathrm{ppm}$ & 11 & 13 & 12 & 2.3 & & 1619 \\
\hline Cs & $\mathrm{ppm}$ & & & & $<20$ & & $<30$ \\
\hline $\mathrm{Ba}$ & $\mathrm{ppm}$ & & & & $<200$ & & $<300$ \\
\hline La & $\mathrm{ppm}$ & $<0.2$ & $<0.2$ & $<0.2$ & $<0.03$ & & 0.064 \\
\hline $\mathrm{Ce}$ & $\mathrm{ppm}$ & & & & 400 & & 4.1 \\
\hline Sm & $\mathrm{ppm}$ & $<0.2$ & $<0.2$ & $<0.2$ & 0.045 & & $<0.2$ \\
\hline $\mathrm{Eu}$ & ppm & $<0.07$ & & & $<0.05$ & & 0.042 \\
\hline$T b$ & $\mathrm{ppm}$ & $<9$ & $<9$ & $<9$ & $<0.2$ & & 0.40 \\
\hline Dy & $\mathrm{ppm}$ & & & & $<0.5$ & & 1.2 \\
\hline Ho & $\mathrm{ppm}$ & $<1$ & $<1$ & $<1$ & & & \\
\hline $\mathrm{Yb}$ & $\mathrm{ppm}$ & $<2$ & $<2$ & $<2$ & $<2$ & & $<0.7$ \\
\hline Lu & $\mathrm{ppm}$ & $<0.8$ & $<0.8$ & $<0.8$ & $<1$ & & $<0.4$ \\
\hline $\mathrm{Hf}$ & $\mathrm{ppm}$ & & & & $<0.9$ & & $<0.5$ \\
\hline $\mathrm{Ta}$ & $\mathrm{ppm}$ & $<0.7$ & & & 1.2 & & 1.2 \\
\hline W & $\mathrm{ppm}$ & 105 & 218 & 108 & 2.8 & & 60 \\
\hline $\mathrm{Pb}$ & $\mathrm{ppm}$ & $<30$ & $<30$ & $<30$ & $<60$ & & $<60$ \\
\hline Th & $\mathrm{ppm}$ & & & & $<1$ & & $<0.5$ \\
\hline U & $\mathrm{ppm}$ & $<4$ & $<5$ & $<4$ & $<0.8$ & & $<1$ \\
\hline
\end{tabular}


TABLE 4.10. Chemical Analysis of Vessel Steels

\begin{tabular}{|c|c|c|c|c|c|c|c|c|c|c|c|}
\hline \multicolumn{2}{|c|}{ Element } & SA 302 & Bellefonte & P34 & P147 & GP55 & P21 & $\mathrm{Pu}$ & P337 & $R R-1$ & GP85 \\
\hline Li & $\mathrm{ppm}$ & 0.30 & & & & & & & & & \\
\hline Na & ppm & 84 & & & & & & & & & \\
\hline INd & ppm & $\begin{array}{r}40 \\
50\end{array}$ & 6.6 & & & & & & & & \\
\hline $\mathrm{Cl}$ & $\begin{array}{l}\mathrm{ppm} \\
\mathrm{pDm}\end{array}$ & $<50$ & $\begin{array}{l}613 \\
<40\end{array}$ & & & & & & & & \\
\hline $\mathrm{K}$ & ppm & $<3$ & 20 & & & & & & & & \\
\hline $\mathrm{Ca}$ & $\mathrm{ppm}$ & 14 & $<400$ & & & & & & & & \\
\hline Sc & $\mathrm{ppm}$ & & 0.26 & & & & & & & & \\
\hline $\mathrm{Ti}$ & $\mathrm{ppm}$ & $<2$ & & & & & & & & & \\
\hline V & $\mathrm{ppm}$ & $<30$ & 74 & $<90$ & $<90$ & $<80$ & $<90$ & $<90$ & $<90$ & $<80$ & 70 \\
\hline $\mathrm{Cr}$ & $\%$ & 0.06 & 0.36 & 0.083 & 0.078 & 0.11 & 0.34 & 0.35 & 0.09 & 0.073 & 0.13 \\
\hline $\mathrm{Mn}$ & $\%$ & 1.49 & 0.76 & 1.20 & 1.23 & 1.32 & 0.20 & 0.44 & 1. & 1.16 & 1.23 \\
\hline $\mathrm{Fe}$ & $\%$ & 98 & 98 & 97 & 97 & 97 & 98 & 97 & 96 & 97 & 97 \\
\hline Co & $\mathrm{ppm}$ & 93 & 151 & & & & & & & & \\
\hline $\mathrm{Ni}$ & $\%$ & $<0.3$ & 0.72 & 0.62 & 0.66 & 0.68 & 0.75 & 0.76 & 0.66 & 0.70 & 0.72 \\
\hline $\mathrm{Cu}$ & ppm & 1900 & 675 & 1480 & 1410 & 1140 & 800 & 1000 & 1450 & 1780 & 1100 \\
\hline $\mathrm{Zn}$ & ppm & 22 & $<4$ & $<70$ & 210 & 170 & $<70$ & $<70$ & 140 & 160 & $<70$ \\
\hline Ga & $\mathrm{ppm}$ & $<20$ & 24 & $<50$ & $<50$ & $<50$ & $<50$ & $<50$ & 300 & 150 & $<50$ \\
\hline As & $\mathrm{ppm}$ & 160 & 63 & 80 & 50 & 260 & 200 & 190 & 3600 & 250 & 470 \\
\hline Se & $\mathrm{ppm}$ & $<9$ & $<0.7$ & $<20$ & $<20$ & $<20$ & $<20$ & $<40$ & $<30$ & $<20$ & $<20$ \\
\hline $\mathrm{Br}$ & $\mathrm{ppm}$ & $<2$ & 0.85 & & & & & & & & \\
\hline $\mathrm{Rb}$ & $\mathrm{ppm}$ & 72 & 23 & & & & & & & & \\
\hline $\mathrm{Sr}$ & $\mathrm{ppm}$ & 0.15 & $<8$ & $<10$ & $<10$ & $<10$ & $<20$ & $<10$ & $<20$ & $<10$ & $<10$ \\
\hline$Y$ & $\mathrm{ppm}$ & $<4$ & $<7$ & $<20$ & $<10$ & $<10$ & $<10$ & $<10$ & 120 & $<10$ & $<10$ \\
\hline $\mathrm{Zr}$ & $\mathrm{ppm}$ & $<4$ & $<7$ & $<10$ & $<10$ & 20 & $<10$ & $<10$ & $<10$ & $<10$ & 20 \\
\hline $\mathrm{Nb}$ & ppm & 40 & $<8$ & 10 & 20 & 20 & 10 & 10 & $<10$ & 40 & 20 \\
\hline Mo & $\%$ & 0.45 & 0.64 & 0.56 & 0.56 & 0.54 & 0.57 & 0.63 & 0.53 & 0.57 & 0.59 \\
\hline $\mathrm{Ag}$ & ppm & $<2$ & $<7$ & & & & & & & & \\
\hline $\mathrm{Sb}$ & $\mathrm{ppm}$ & 16 & 6.1 & & & & & & & & \\
\hline Cs & ppm & & $<0.2$ & & & & & & & & \\
\hline $\mathrm{Ba}$ & $\mathrm{ppm}$ & $<800$ & $<270$ & & & & & & & & \\
\hline La & $\mathrm{ppm}$ & $<0.2$ & 0.10 & & & & & & & & \\
\hline $\mathrm{Ce}$ & $\mathrm{ppm}$ & & $<1$ & & & & & & & & \\
\hline Sn & $\mathrm{ppm}$ & $<0.09$ & 0.017 & & & & & & & & \\
\hline Elu & $\mathrm{ppm}$ & $<0.2$ & 0.031 & & & & & & & & \\
\hline $\mathrm{Tb}$ & $\mathrm{ppm}$ & & 0.45 & & & & & & & & \\
\hline $\mathrm{Hf}$ & ppm & $<0.6$ & $<1$ & & & & & & & & \\
\hline$Y b$ & $\mathrm{ppm}$ & $<1$ & 0.81 & & & & & & & & \\
\hline Lu & $\mathrm{ppm}$ & $<0.3$ & 0.12 & & & & & & & & \\
\hline $\mathrm{Hf}$ & ppm & & 0.21 & & & & & & & & \\
\hline $\mathrm{Ta}$ & ppm & $<0.3$ & 0.13 & & & & & & & & \\
\hline$W$ & ppm & 5 & 5.9 & & & & & & & & \\
\hline $\mathrm{Pb}$ & $\mathrm{ppm}$ & $<40$ & $<50$ & $<50$ & $<40$ & $<40$ & $<40$ & $<50$ & 7730 & 60 & 90 \\
\hline $\mathrm{Th}$ & ppm & $<4$ & 0.18 & & & & & & & & \\
\hline U & $\mathrm{ppm}$ & $<2$ & 0.20 & & & & & & & & \\
\hline
\end{tabular}




\section{TABLE 4.11. Vessel Steels Composition Summary}

\begin{tabular}{|c|c|c|c|c|c|c|c|}
\hline \multicolumn{2}{|c|}{ Element } & Average & S.D..$^{.0}(a)$ & \multicolumn{2}{|c|}{ Range } & $\begin{array}{l}\text { Range (b) } \\
\text { Factor }\end{array}$ & $\begin{array}{c}\text { No. of } \\
\text { Measurements } \\
\text { Used }\end{array}$ \\
\hline$L_{N} i$ & ppm & 0.30 & & & & & 1 \\
\hline $\mathrm{Na}$ & ppm & $23+24$ & 102 & 6.6 & to 40 & 6.1 & 2 \\
\hline Al & ppm & $330 \pm 400$ & 102 & $<50$ & to 613 & 712 & 2 \\
\hline Cl & ppm & $\overrightarrow{4} 0$ & & & & & 1 \\
\hline K & $\mathrm{ppm}$ & $12 \pm 12$ & 100 & $<3$ & to 20 & & 2 \\
\hline $\mathrm{Ca}$ & $\mathrm{ppm}$ & $\overline{14}$ & & & & & 1 \\
\hline Sc & ppm & 0.26 & & & & & 1 \\
\hline $\mathrm{Ti}$ & ppm & $<2$ & & & & & 1 \\
\hline v & $\mathrm{ppm}$ & $<80$ & & $<30$ & to 90 & & 10 \\
\hline $\mathrm{Cr}$ & $\%$ & $0.17 \pm 0.13$ & & 0.06 & to 0.36 & & 10 \\
\hline$M n$ & $\%$ & $1.02 \pm 0.41$ & & 0.2 & to 1.49 & & 10 \\
\hline $\mathrm{Fe}$ & $\%$ & $\overline{9} 8$ & & & & & 10 \\
\hline Co & $\mathrm{ppm}$ & $122 \pm 41$ & 34 & 93 & to 151 & & 2 \\
\hline $\mathrm{Ni}$ & $\%$ & $0.66 \pm 0.13$ & 20 & $<0.3$ & to 0.76 & & 10 \\
\hline $\mathrm{Cu}$ & ppm & $1274 \pm 400$ & 31 & 675 & to 1900 & & 10 \\
\hline $2 n$ & ppm & $\approx 10 \overline{0}$ & & $<4$ & to 210 & 753 & 10 \\
\hline $\mathrm{Ga}$ & ppm & $\approx 80$ & & $<20$ & to 300 & & 10 \\
\hline As & ppm & $532 \pm 1085$ & 204 & 50 & to 3600 & 72.0 & 10 \\
\hline Se & ppm & 0.7 & & & & & 1 \\
\hline $\mathrm{Br}$ & ppm & 0.85 & & & & & 1 \\
\hline $\mathrm{Rb}$ & ppm & $48 \pm 35$ & & 23 & to 72 & & 2 \\
\hline Sr & ppm & 0.15 & & & & & 1 \\
\hline Y & $\rho p m$ & $<20$ & & & & & 10 \\
\hline $\mathrm{Zr}$ & ppm & $<10$ & & & & & 10 \\
\hline $\mathrm{Nb}$ & ppm & $18.8 \pm 12.2$ & 65 & $<8$ & to 40 & & 10 \\
\hline Mo & ppm & $0.56 \pm 0.05$ & 10 & 0.45 & to 0.63 & & 10 \\
\hline $\mathrm{Ag}$ & $\mathrm{ppm}$ & $<\overline{2}$ & & & & & 1 \\
\hline $\mathrm{Sb}$ & $\mathrm{ppm}$ & $11 \pm 7$ & 64 & 6.1 & to 16 & & 2 \\
\hline Cs & ppm & $<0.2$ & & & & & 1 \\
\hline La & ppm & 0.10 & & & & & 1 \\
\hline $\mathrm{Ba}$ & $\mathrm{ppm}$ & 273 & & & & & 1 \\
\hline $\mathrm{Ce}$ & $\mathrm{ppm}$ & $<1$ & & & & & 1 \\
\hline Sm & ppm & 0.017 & & & & & 1 \\
\hline $\mathrm{Eu}$ & $\mathrm{ppm}$ & 0.031 & & & & & 1 \\
\hline Tb & $\mathrm{ppm}$ & 0.45 & & & & & 1 \\
\hline Dy & ppm & & & & & & \\
\hline Ho & $\mathrm{ppm}$ & $<0.8$ & & & & & 2 \\
\hline$Y b$ & ppm & $<1$ & & & & & 2 \\
\hline Lu & ppm & $<0.2$ & & & & & 2 \\
\hline $\mathrm{Hf}$ & ppm & 0.21 & & & & & 1 \\
\hline $\mathrm{Ta}$ & $\mathrm{ppm}$ & 0.13 & & & & & 1 \\
\hline$W$ & ppm & $5.5 \pm 0.6$ & & & & & 2 \\
\hline $\mathrm{Pb}$ & $\mathrm{ppm}$ & $820 \mp 2430$ & & & & & 10 \\
\hline Th & ppm & 0.18 & & & & & 1 \\
\hline $\mathrm{U}$ & $\mathrm{ppm}$ & 0.20 & & & & & 1 \\
\hline
\end{tabular}

(a) Relative standard deviation expressed as a percentage of the average value

(b) Range factor shown is the ratio of the highest to lowest value measured 
carbon steel are probably related to the original ore body rather than any manufacturing artifacts, as may be the case with stainless.

\subsubsection{Rebar}

Table 4.12 lists results for the analysis of a total of 48 rebar samples with a summary in Table 4.13. The composition is relatively constant both within a given site as well as between sites. The cobalt is about the same as for the vessel steels at about $100 \mathrm{ppm}$. Except for the Wolf Creek samples, all are low in niobium. An interesting feature of the rebar is the presence of measurable amounts of silver in a number of the samples. This may be caused by the use of recycled materials in the manufacture of rebar. The amounts involved are too small to result in any significant amount of activation products.

\subsubsection{Concrete}

Table 4.14 lists concrete composition results for 36 samples taken at 12 sites. In most cases, compositional variation was rather minimal at a given site while large differences are seen between sites reflecting geological differences between quarry sites. The range of variation is summarized in Table 4.15. Range factors for key elements are between one and two orders of magnitude. The europium isotopes, for example, would be much more abundant at the WPPSS site which uses a basalt aggregate than at sites such as Turkey Point or the two TVA reactors which use a limestone aggregate. The limestone-based concretes, however, are higher in other activatible elements such as $\mathrm{Ca}$, and U. Each reactor would thus have to be handled in a site-specific fashion if a detailed activation products inventory is required. This situation is illustrated in Table 4.16 which tabulates the cobalt to europium ratios for several concretes. This ratio varies by about a factor of three thus making a significant difference in whether ${ }^{60} \mathrm{Co}$ or ${ }^{152} \mathrm{Eu}$ would dominate.

The bioshield concrete obtained in this study can be regarded as representative of rather ordinary rock. This is illustrated in Figure 4.1 in which the average elemental abundances given in Table 4.15 are normalized to the average crustal abundance pattern given by Mason (1966). The large error bars simply reflect the average range of variability. The dashed line in the figure at unity represents the composition of typical crustal rock. Most of the elements plotted fall close to or below this line. Calcium and sulfur are higher due to the addition of cement. A few other elements were up to an order of magnitude higher. These include $\mathrm{As}$, Se, Mo, Sb, and $\mathrm{Pb}$, none of which influence the activation products inventory significantly. Interestingly, Eu and Co both plotted below crustal abundance. 
TABLE 4.12. Chemical Analysis of Rebar

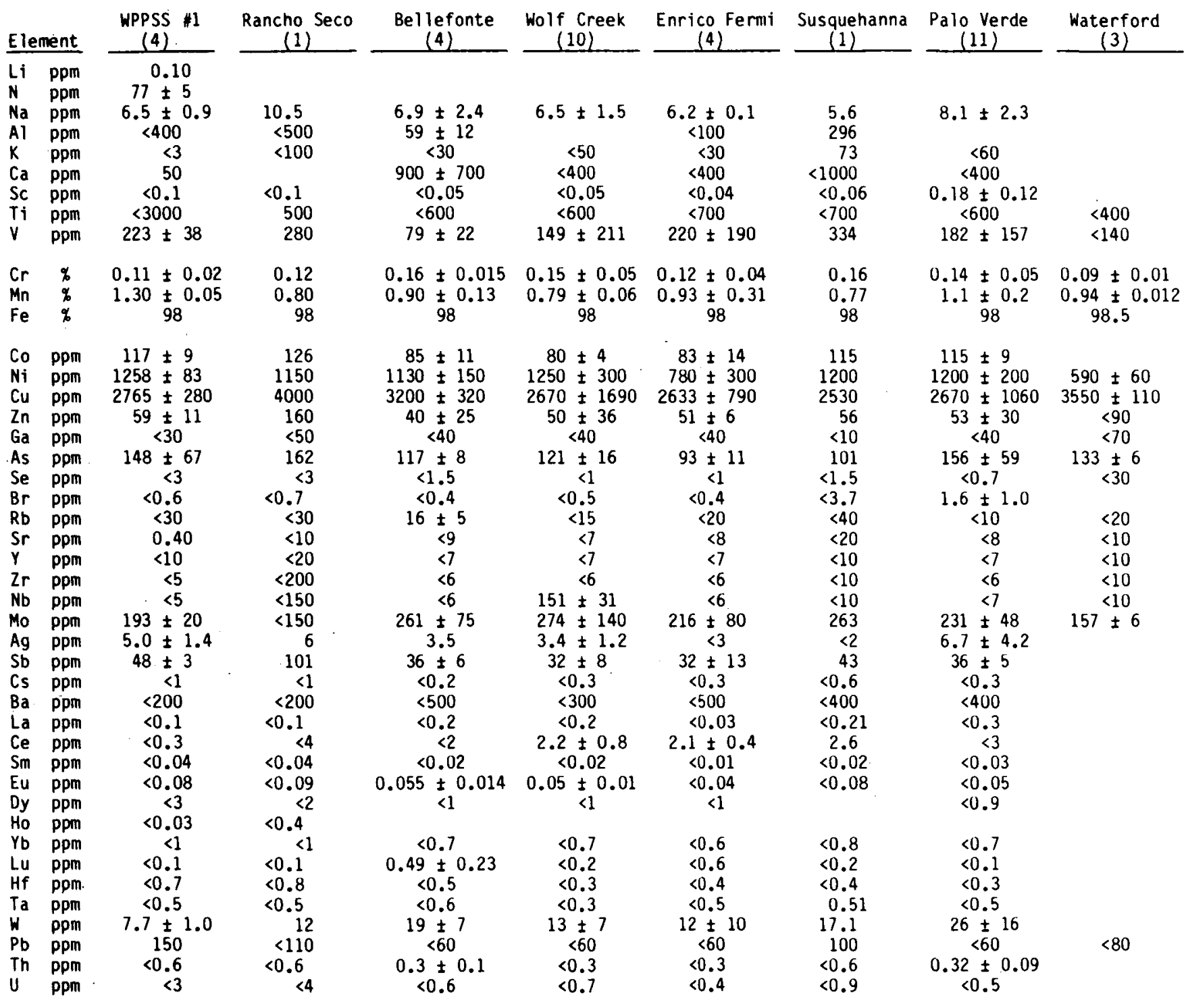

Note: Numbers in parenthesis indicate number of samples analyzed at each site. Numbers in the table are averages and standard deviations for that number of samples. 


\section{TABLE 4.13. Rebar Composition Summary}

\begin{tabular}{|c|c|c|c|c|c|c|}
\hline \multicolumn{2}{|c|}{ Element } & Average & $\begin{array}{l}q(a) \\
\text { S.D. }\end{array}$ & Range & \multirow[t]{2}{*}{$\begin{array}{l}\text { Range } \\
\text { Factor (b) }\end{array}$} & \multirow{2}{*}{$\begin{array}{c}\begin{array}{c}\text { No. of } \\
\text { Measurements } \\
\text { Used }\end{array} \\
1\end{array}$} \\
\hline Li & $\mathrm{ppm}$ & 0.10 & & & & \\
\hline N & $\mathrm{ppm}$ & 77 & & & & 1 \\
\hline $\mathrm{Na}$ & $\mathrm{ppm}$ & $7.2 \pm 1.7$ & 23 & 5.6 to 10.5 & 1.9 & 7 \\
\hline Al & $\mathrm{ppm}$ & $180 \pm 170$ & 94 & 59 to 296 & 5.0 & 2 \\
\hline k & $\mathrm{ppm}$ & $\simeq 40$ & & $<3$ to 73 & 724 & 7 \\
\hline $\mathrm{Ca}$ & $\mathrm{ppm}$ & $\simeq 50$ & & & & 1 \\
\hline Sc & $\mathrm{ppm}$ & $<0.1$ & & & & 7 \\
\hline $\mathrm{Ti}$ & $\mathrm{ppm}$ & $<700$ & & & & 7 \\
\hline V & $\mathrm{ppm}$ & $201 \pm 81$ & 41 & 74 to 334 & 4.2 & 8 \\
\hline $\mathrm{Cr}$ & $q$ & $0.131 \pm 0.025$ & 19 & 0.09 to 0.16 & 1.8 & 8 \\
\hline$M n$ & $\%$ & $0.94 \pm 0.18$ & 19 & 0.77 to 1.30 & 1.7 & 8 \\
\hline $\mathrm{Fe}$ & $q$ & -98 & & & & 8 \\
\hline
\end{tabular}

\begin{tabular}{|c|c|c|c|c|c|c|c|}
\hline Co & ppm & $103 \pm 19$ & 19 & 80 & to 126 & 1.6 & 78 \\
\hline $\mathrm{Ni}$ & ppm & $1070 \pm 250$ & 23 & 590 & to 1260 & 2.1 & 8 \\
\hline $\mathrm{Cu}$ & ppm & $2980 \pm 550$ & 18 & 2530 & to 4000 & 1.6 & 8 \\
\hline $2 n$ & ppm & $67 \pm 41$ & 62 & 40 & to 160 & 4.0 & 7 \\
\hline Ga & $\mathrm{ppm}$ & & $<50$ & & & & 7 \\
\hline As & ppm & $129 \pm 25$ & 20 & 93 & to 162 & 1.7 & 8 \\
\hline $\mathrm{Se}$ & $p p m$ & & $<2$ & & & & 7 \\
\hline $\mathrm{Br}$ & ppm & $<1.1$ & & $<0.4$ & to 3.7 & $<9.3$ & 8 \\
\hline $\mathrm{Rb}$ & ppm & $<20$ & & & & & 8 \\
\hline$S r$ & $p p m$ & 0.40 & - & & & & 1 \\
\hline Y & ppin & & $<10$ & & & & 8 \\
\hline $2 r$ & $\mathrm{ppm}$ & & $<10$ & & & & 7 \\
\hline $\mathrm{Nb}$ & $\rho m$ & & $<40$ & $<5$ & to 151 & & 8 \\
\hline Mo & ppm & $218 \pm 48$ & 22 & 150 & to 274 & 1.8 & 8 \\
\hline $\mathrm{Ag}$ & $\rho \rho m$ & $4.2 \pm 1.7$ & 40 & $<2.0$ & to 6.7 & 3.4 & 7 \\
\hline Sb & ppm & $47 \pm 24$ & 51 & 32 & to 101 & 3.2 & 7 \\
\hline $\mathrm{Cs}$ & $p p m$ & $<0.6$ & & & & & 5 \\
\hline $\mathrm{Ba}$ & $\rho p \pi$ & $<400$ & & & & & 5 \\
\hline La & $\rho p r$ & $<0.3$ & & & & & 7 \\
\hline re.e. & $\mathrm{ppm}$ & & $<3$ & & . & & 6 \\
\hline $\mathrm{Sm}$ & ppm & $<0.04$ & & & & & 7 \\
\hline Eu & ppm & $<0.09$ & & & & & 7 \\
\hline Dy & ppm & & $<1$ &. & & & 4 \\
\hline Ho & $\rho p m$ & $<0.04$ & & & & & 2 \\
\hline$y_{b}$ & $p p m$ & & $<1$ & & & & 7 \\
\hline Lu & ppm & $<0.6$ & & & & & 7 \\
\hline $\mathrm{Hf}$ & $\mathrm{ppm}$ & $<0.8$ & & , & & & 7 \\
\hline $\mathrm{Ta}$ & ppin & (1). 6 & & & & & 7 \\
\hline$W$ & $\rho p m$ & $15 \pm 6$ & 39 & 7.7 & to 26.0 & 7 & \\
\hline $\mathrm{Pb}$ & pprn & & $\langle 90$ & & & & 8 \\
\hline In & $p p m$ & (1). 6 & & & & & 7 \\
\hline 1) & ppm & $<0.9$ & & & & & 5 \\
\hline
\end{tabular}

(a) Relative Standard Deviation expressed as a percentage of the average value.

(b) Range factor shown is the ratio of the highest to lowest value ineasured. 
TABLE 4.14. Chemical Analysis of Bioshield Concrete

\begin{tabular}{|c|c|c|c|c|c|c|c|c|c|c|c|c|c|}
\hline Eleme & & $\begin{array}{l}\text { WPPSS } \\
(4)\end{array}$ & $\begin{array}{l}\text { Rancno Seco } \\
\text { (1) } \\
\end{array}$ & $\begin{array}{c}\text { Bellefonte } \\
(4)\end{array}$ & $\begin{array}{c}\text { Hartsville } \\
(3) \\
\end{array}$ & $\begin{array}{l}\text { Wol f Creek } \\
\end{array}$ & $\begin{array}{l}\text { Palo Verde } \\
(2)^{2}\end{array}$ & $\begin{array}{l}\text { Enrico fermi } \\
\text { (2) }\end{array}$ & Turkey Point & $\begin{array}{l}\text { Pathfinder } \\
\text { (3) }\end{array}$ & $\begin{array}{l}\text { Humbol dt Bay } \\
(4)^{2}\end{array}$ & $\begin{array}{l}\text { Waterford } \\
\text { (2) }\end{array}$ & $\begin{array}{c}\text { Susquenanna } \\
\text { (5) }\end{array}$ \\
\hline 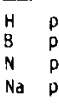 & $\begin{array}{l}\mathrm{ppm} \\
\mathrm{ppm} \\
\mathrm{ppm} \\
\mathrm{ppm}\end{array}$ & $\begin{aligned} 6100 & \pm 30 \\
15.3 & \pm 0.2 \\
107 & \pm 47 \\
15500 & \pm 1300\end{aligned}$ & $\begin{array}{r}6000 \\
26 \\
140 \\
13500\end{array}$ & $650 \pm 160$ & $510 \div 30$ & $390 \pm 10$ & $18200 \pm 1600$ & $5240 \pm 1950$ & $176 \pm 23$ & $6320 \pm 1480$ & $18940 \pm 1690$ & & 1830 \\
\hline & $\begin{array}{l}8 \\
z \\
8\end{array}$ & $\begin{aligned} & 5.5 \pm 0.3 \\
& 21.5 \pm 1.7 \\
& 0.81 \pm 0.33 \\
& 0.46 \pm 0.12\end{aligned}$ & $\begin{array}{c}5.7 \\
23.9 \\
0.92 \\
0.44\end{array}$ & $\begin{array}{c}1.5 \pm 0.3 \\
3.9 \pm 0.7 \\
00.5 \\
0.26 \pm 0.05\end{array}$ & $\begin{array}{c}1.3 \pm 0.3 \\
4.2 \pm 0.5 \\
<0.5 \\
0.33 \pm 0.02\end{array}$ & $\begin{array}{c}1.8 \pm 0.1 \\
12.3 \pm 2.2 \\
<0.9 \\
0.25 \pm 0.08\end{array}$ & $\begin{array}{c}6.1 \pm 0.1 \\
26.7 \pm 2.7 \\
00.5 \\
0.27 \pm 0.12\end{array}$ & $\begin{array}{c}2.0 \pm 0.4 \\
9.2 \pm 4.0 \\
<0.2 \\
0.42 \pm 0.06\end{array}$ & $\begin{array}{c}0.53 \pm 0.01 \\
8.5 \pm 1.3 \\
<0.2 \\
0.20 \pm 0.04\end{array}$ & $\begin{array}{c}2.2 \pm 0.3 \\
25.4 \pm 1.6 \\
<0.1 .6 \\
0.20 \pm 0.04\end{array}$ & $\begin{array}{rl}5.1 & \pm 0.5 \\
20.3 & \pm 2.71 \\
<0.1 & 0.1 \\
0.20 & \pm 0.07\end{array}$ & $\begin{array}{l}1.6 \pm 0.1 \\
32.4 \pm 2.4 \\
0.0 .4 \\
0.43 \pm 0.11\end{array}$ & $\begin{array}{r}2.1 \\
12.7 \\
<0.2 \\
0.3\end{array}$ \\
\hline$c l p$ & $p p m$ & $59 \pm 12$ & 56 & & $23 \pm 4$ & & $56 \pm 22$ & $51 \pm 6$ & $11.0 \pm 1.5$ & $46 \pm 19$ & $58 \pm 31$ & & \\
\hline $\begin{array}{l}k \\
c_{a}\end{array}$ & $\%$ & $\begin{array}{r}1.2 \pm 0.4 \\
14.0 \pm 2.2\end{array}$ & $\begin{array}{r}1.1 \\
12.3\end{array}$ & $\begin{array}{l}0.29 \pm 0.04 \\
32.4 \pm 1.9\end{array}$ & $\begin{array}{l}0.31 \pm 0.05 \\
34.7 \pm 2.8\end{array}$ & $\begin{array}{l}0.93 \pm 0.06 \\
26.8 \pm 1.7\end{array}$ & $\begin{array}{l}2.5 \pm 0.3 \\
9.2 \pm 2.1\end{array}$ & $\begin{array}{l}0.60 \pm 0.04 \\
17.5 \pm 3.5\end{array}$ & $\begin{array}{c}0.047 \pm 0.002 \\
29.4 \pm 0.9\end{array}$ & $\begin{aligned} & 0.61 \pm 0.11 \\
& 8.3 \pm 1.9\end{aligned}$ & $\begin{aligned} 0.84 & \pm 0.12 \\
8.5 & \pm .8\end{aligned}$ & $\begin{array}{rl}0.080 & \pm 0.001 \\
12.0 & 1.6\end{array}$ & $\begin{array}{r}0.5 \\
15.0\end{array}$ \\
\hline $\begin{array}{ll}\text { Sc } & p \\
T i & p \\
v & p \\
c r & p \\
\text { Mn } & p\end{array}$ & $\begin{array}{l}\rho p m \\
\rho p m \\
p \rho m \\
p p m \\
p p m\end{array}$ & $\begin{aligned} 17.4 & \pm 0.6 \\
7900 \pm 1400 & \pm 0 \\
180 \pm 8 & \pm \\
37 & \pm \\
990 \pm & \pm 00\end{aligned}$ & $\begin{array}{r}16.2 \\
4100 \\
150 \\
209 \\
710\end{array}$ & $\begin{aligned} 2.9 & \pm 0.4 \\
840 \pm 80 & \pm \\
39 & \pm 4 \\
30 & \pm 2 \\
127 & \pm 11\end{aligned}$ & $\begin{aligned} & 2.3 \pm 0.6 \\
& 850 \pm 130 \pm \\
& 37 \pm 12 \\
& 19 \pm 4 \\
& 214 \pm 15\end{aligned}$ & $\begin{aligned} 1.09 & \pm 0.03 \\
660 & \pm 360 \\
28.5 & \pm 1.4 \\
31 & \pm 2 \\
340 & \pm 70\end{aligned}$ & $\begin{array}{r}5.3 \pm 1.1 \\
2100 \pm 300 \\
34 \pm 7 \\
47 \pm 12 \\
290 \pm 50\end{array}$ & $\begin{aligned} 3.0 & \pm 0.6 \\
1030 & \pm 260 \\
32 & \pm 7 \\
26.7 & \pm \\
270 & \pm 20\end{aligned}$ & $\begin{aligned} 0.73 & \pm 0.01 \\
230 & \pm 40 \\
13.3 & \pm 0.6 \\
19.1 & \pm 0.2 \\
56 & \pm 5\end{aligned}$ & $\begin{aligned} 2.4 & \pm 0.6 \\
620 & \pm 30 \\
16 & \pm 3 \\
40 & \pm 16 \\
214 & \pm 6\end{aligned}$ & $\begin{aligned} 14.7 & \pm 2.0 \\
2850 & \pm 140 \\
115 & \pm 8 \\
540 & \pm 330 \\
590 & \pm 60\end{aligned}$ & $600 \pm 14$ & $\begin{array}{r}6 \\
3600 \\
490 \\
200 \\
640\end{array}$ \\
\hline $\mathrm{Fe}$ & $\%$ & $5.0 \pm 0.2$ & 3.6 & $0.9 \pm 0.3$ & $1.1 \pm 0.2$ & $1.05 \pm 0.12$ & $1.9 \pm 0.4$ & $1.1 \pm 0.3$ & $0.50 \pm 0.01$ & $1.2 \pm 0.1$ & $4.4 \pm 0.7$ & $0.70 \pm 0.09$ & 24 \\
\hline $\begin{array}{ll}\text { Co } & p \\
\text { Ni } & p \\
\text { Cu } & p \\
Z n & p \\
\text { Ga } & p \\
\text { As } & p \\
\text { Se } & p \\
\text { Br } & p \\
\text { Ro } & p \\
\text { Sr } & p \\
\text { Y } & p \\
Z r & p \\
\text { No } & p \\
\text { Mo } & p \\
\text { Pd } & p \\
\text { Ag } & p \\
\text { Cd } & p \\
\text { Sn } & p \\
\text { Sb } & p \\
\text { CS } & p \\
\text { da } & p \\
\text { La } & p \\
\text { Ce } & p \\
\text { Nd } & p\end{array}$ & 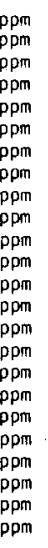 & 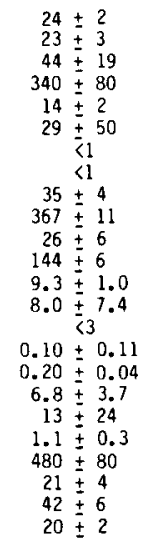 & $\begin{array}{r}15 \\
70 \\
46 \\
68 \\
12 \\
6.6 \\
<1 \\
<1 \\
29 \\
422 \\
16 \\
92 \\
5.4 \\
2.5 \\
<3 \\
<0.4 \\
0.35 \\
<3 \\
1.0 \\
1.3 \\
630 \\
15 \\
28 \\
14\end{array}$ & $\begin{array}{rl}4.1 & \pm 0.5 \\
35 & \pm 6 \\
21 & \pm 4 \\
17 & 413 \\
3.3 & \pm 0.4 \\
13.6 & \pm 5.1 \\
0.99 & \pm 0.14 \\
2.4 & \pm 1.0 \\
15 & \pm 2 \\
560 & \pm 120 \\
10 & 120 \\
35 & 1 \\
1.9 & \pm 0.8 \\
3.0 & \pm 1.4 \\
& <0.4\end{array}$ & 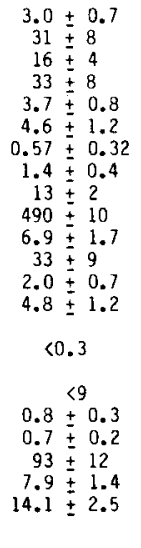 & 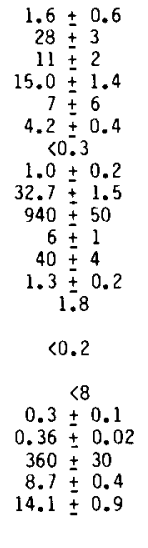 & $\begin{aligned} & 5.6 \pm 2.0 \\
& 30 \pm 4 \\
& 28 \pm 7 \\
& 90 \pm 60 \\
& 13 \pm 1 \\
& 13.6 \pm 1.7 \\
& 2.0 \pm 0.3 \\
& 2.0 \pm 0.9 \\
& 170 \pm 110 \\
& 220 \pm 40 \\
& 96 \pm 97 \\
& 160 \pm 6 \\
& 9.2 \pm 1.1 \\
& 7.2 \pm 0.9 \\
&<0.3\end{aligned}$ & $\begin{array}{rl}3.8 & \pm 1.0 \\
14 & \pm 4 \\
10 & \pm 4 \\
33 & \pm 6 \\
5.5 & \pm 1.0 \\
4.9 & 1.9 \\
0.71 & \pm 0.26 \\
5.6 & \pm 1.6 \\
22 & \\
310 & \pm 80 \\
6.7 & \pm .44 \\
52 \pm 17 \\
1.8 \pm 0.7 \\
3.5 \pm 0.5 \\
<0.2 \\
<6 \\
0.5 \pm 0.4 \\
0.54 \pm 0.01 \\
7060 \pm 9750 \\
9.4 \pm 0.6 \\
15.5 \pm 0.7 \\
<17\end{array}$ & $\begin{array}{c}1.1 \pm 0.10 \\
<14 \\
10 \pm 4 \\
8.4 \pm 0.5 \\
1.05 \pm 0.7 \\
0.89 \pm 0.08 \\
0.26 \pm 0.04 \\
1.7 \pm 0.3 \\
2.5 \pm 0.4 \\
680 \pm 40 \\
3.0 \pm 1.1 \\
27 \pm 4 \\
20 \\
26 \pm 16 \\
<0.2 \\
<10 \\
0.16 \pm 0.01 \\
0.52 \pm 0.01 \\
<20 \\
2.9 \pm 0.2 \\
6.2 \pm 0.7 \\
<20\end{array}$ & $\begin{aligned} 2.1 & \pm 1.7 \\
44 & \pm 3 \\
12 & \pm 2 \\
30 & \pm 6 \\
5.9 & \pm 0.6 \\
3.0 & \pm 0.3 \\
0.71 & \pm 0.21 \\
3.3 & \pm 1.3 \\
20 & \pm 3 \\
260 & \pm 100 \\
4.5 & \pm 2.2 \\
54 & \pm 13 \\
2.1 & \pm 0.1 \\
36 & \pm 5 \\
<0.3 & \\
<0.3 & <9 \\
0.40 & \pm 0.11 \\
0.32 & \pm 0.02 \\
280 & \pm 40 \\
12.5 & \pm 0.3 \\
26.4 & \pm 0.4 \\
& <23\end{aligned}$ & 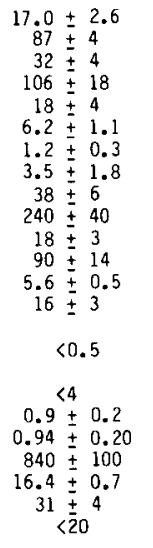 & $\begin{array}{c}11.9 \pm 0.4 \\
10.9 \pm 1.1 \\
15.2 \pm 15 \\
1.8 \pm 0.3 \\
2.8 \pm 1.2 \\
\leq 1.1 \\
<0.8 \\
2.92 \pm 0.06 \\
361 \pm 15 \\
4.7 \pm 0.4 \\
40 \pm 4 \\
3.7 \pm 0.05 \\
4.35 \pm 0.27\end{array}$ & $\begin{array}{r}31 \\
70 \\
60 \\
80 \\
20 \\
9 \\
0.56 \\
1 \\
40 \\
410 \\
20 \\
90 \\
7 \\
10 \\
<0.5\end{array}$ \\
\hline $\begin{array}{ll}\text { Sm } & p \\
\text { Eu } & p \\
\text { Gd } & p \\
\text { To } & p \\
\text { Dy } & p \\
\text { Ho } & p \\
\text { yb } & p \\
\text { Lu } & p \\
\text { Hf } & p \\
\text { To } & p \\
\text { d } & p \\
\text { p } & p \\
\text { Th } & p \\
U & p\end{array}$ & 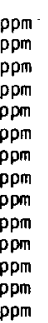 & 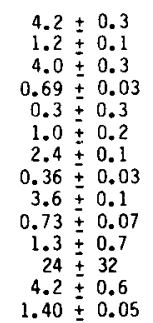 & $\begin{array}{l}0.42 \\
1.0 \\
3.0 \\
0.48 \\
2.9 \\
0.4 \\
1.6 \\
0.31 \\
2.7 \\
0.46 \\
1.1 \\
8.0 \\
3.3 \\
1.5\end{array}$ & $\begin{array}{c}0.98 \pm 0.07 \\
0.23 \pm 0.03 \\
0.80 \pm 0.10 \\
0.22 \pm 0.03 \\
0.8 \pm 0.4 \\
9.6 \pm 3.8 \\
2.4 \pm 0.3 \\
4.0 \pm 0.5\end{array}$ & $\begin{array}{c}0.79 \pm 0.11 \\
0.18 \pm 0.04 \\
0.98 \pm 0.07 \\
0.20 \pm 0.04 \\
0.5 \pm 0.3 \\
5.4 \pm 3.2 \\
1.9 \pm 0.5 \\
2.8 \pm 0.7\end{array}$ & $\begin{array}{c}0.64 \pm 0.05 \\
0.15 \pm 0.03 \\
1.39 \pm 0.15 \\
0.17 \pm 0.03 \\
<0.5 \\
7.8 \pm 8.3 \\
1.9 \pm 0.1 \\
2.8 \pm 0.4\end{array}$ & $\begin{array}{rl}3.9 & \pm 0.3 \\
0.77 & \pm 0.01 \\
0.78 & \pm 0.14 \\
3.0 & 0.6 \\
0.85 & \pm 0.08 \\
3.0 \pm 0.8 \\
0.15 & \pm 0.11 \\
5.7 & \pm 0.8 \\
0.90 & \pm 0.32 \\
3.9 & \pm 0.4 \\
34 & \pm 6 \\
12 & \pm 2 \\
2.7 & 0.8\end{array}$ & $\begin{array}{rl}1.7 \pm 0.2 & \pm 0.2 \\
0.34 & \pm 0.06 \\
0.29 & \pm 0.06 \\
1.15 & \pm 0.07 \\
0.9 & \pm 0.2 \\
0.19 & 0.01 \\
2.0 & 0.2 \\
0.24 & 0.04 \\
0.6 & 0.3 \\
5.9 & 5.2 \\
2.11 & \pm 0.06 \\
3.0 \pm 0.7\end{array}$ & $\begin{array}{r}0.55 \pm 0.20 \\
0.38 \pm 0.01 \\
0.20 \pm 0.05 \\
0.65 \pm 0.04 \\
0.092 \pm 0.06 \\
0.39 \pm 0.16 \\
\$ 6 \\
0.75 \pm 0.09 \\
4.4 \pm 0.3\end{array}$ & $\begin{aligned} 1.55 & \pm 0.12 \\
0.21 & \pm 0.18 \\
0.27 & \pm 0.05 \\
1.8 & \pm 0.3 \\
0.88 & \pm 1.11 \\
0.19 & \pm 0.05 \\
1.9 & \pm 0.6 \\
0.23 & \pm 0.03 \\
2.1 & \pm 1.7 \\
15 & \pm 13 \\
3.36 & \pm 0.01 \\
1.8 & \pm 0.6\end{aligned}$ & 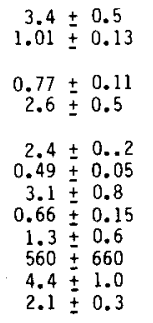 & & \\
\hline
\end{tabular}


TABLE 4.15. Bioshield Concrete Composition Summary

\begin{tabular}{|c|c|c|c|c|c|c|}
\hline \multicolumn{2}{|c|}{ Element } & \multirow{3}{*}{ 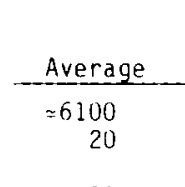 } & \multirow[t]{2}{*}{$\begin{array}{c}\% \\
\text { S.D. (b) }\end{array}$} & Range & \multirow[t]{2}{*}{$\begin{array}{l}\text { Range } \\
\text { Factor (a) }\end{array}$} & \multirow{2}{*}{$\begin{array}{c}\text { No. of } \\
\begin{array}{c}\text { Measurements }(a) \\
\text { Used }\end{array} \\
2\end{array}$} \\
\hline$H$ & $\mathrm{ppm}$ & & & & & \\
\hline $\mathrm{Li}$ & $\mathrm{ppm}$ & & & & & $\begin{array}{l}\text { Crustal } \\
\text { Abundance }\end{array}$ \\
\hline B & $\mathrm{ppm}$ & $\simeq 20$ & & & & 2 \\
\hline $\mathrm{N}$ & ppm & $\simeq 120$ & & & & 2 \\
\hline $\mathrm{Na}$ & $\mathrm{ppm}$ & $7390 \pm 7640$ & 103 & 176 to 18940 & 108 & 11 \\
\hline Al & $\%$ & $3.1 \pm 2.0$ & 67 & 0.53 to 6.1 & 11.5 & 11 \\
\hline $\mathrm{Si}$ & $\%$ & $16.8 \pm 9.5$ & 57 & 3.9 to 32.4 & 8.3 & 12 \\
\hline $\mathrm{p}$ & $\%$ & $<0.5$ & & & & 12 \\
\hline S & $\%$ & $0.31 \pm 0.10$ & 32 & 0.20 to 0.46 & 2.3 & 12 \\
\hline $\mathrm{Cl}$ & $\mathrm{ppm}$ & $45 \pm 18$ & 40 & 11 to 59 & 5.9 & 8 \\
\hline$k$ & $\%$ & $0.75 \pm 0.67$ & 89 & 0.047 to 2.5 & 53.2 & 12 \\
\hline $\mathrm{Ca}$ & $\%$ & $18.3 \pm 9.7$ & 53 & 8.3 to 34.7 & 4.2 & 12 \\
\hline Sc & ppm & $6.5 \pm 6.3$ & 97 & 0.73 to 17.4 & 23.8 & 11 \\
\hline$T i$ & $\mathrm{ppm}$ & $2121 \pm 2320$ & 105 & 230 to 7900 & 34.4 & 12 \\
\hline v & $\mathrm{ppm}$ & $103 \pm 140$ & 136 & 13.3 to 490 & 36.8 & 11 \\
\hline $\mathrm{Cr}$ & ppm & $109 \pm 159$ & 146 & 29.0 to 540 & 28.4 & 11 \\
\hline Mn & $\mathrm{ppm}$ & $377 \pm 290$ & 77 & 56 to 990 & 17.7 & 12 \\
\hline $\mathrm{Fe}$ & $\%$ & $3.9 \pm 6.4$ & 172 & 0.50 to 24.0 & 48.0 & 12 \\
\hline Co & $\mathrm{ppm}$ & $9.8 \pm 10.3$ & 105 & 1.1 to 31.0 & 28.2 & 11 \\
\hline $\mathrm{Ni}$ & $\mathrm{ppm}$ & $38 \pm 25$ & 65 & 11.9 to 87.0 & 7.3 & 12 \\
\hline $\mathrm{Cu}$ & $\mathrm{ppm}$ & $25 \pm 17$ & 68 & 10 to 60 & 6.0 & 12 \\
\hline $2 n$ & $\mathrm{ppm}$ & $75 \pm 90$ & 120 & 8.4 to. 340 & 40.5 & 12 \\
\hline Ga & $\mathrm{ppm}$ & $8.8 \pm 6.4$ & 73 & $1: 05$ to 20 & 19.1 & 12 \\
\hline As & $\mathrm{ppm}$ & $7.9 \pm 7.9$ & 100 & 0.89 to 29 & 32.6 & 12 \\
\hline Se & $\mathrm{ppm}$ & $0.92 \pm 0.56$ & 61 & 0.26 to 2.0 & 7.7 & 7 \\
\hline $\mathrm{Br}$ & $\mathrm{ppm}$ & $2.4 \pm 1.5$ & 61 & 1.0 to 5.6 & 5.6 & 9 \\
\hline $\mathrm{Rb}$ & ppm & $35 \pm 44$ & 127 & 2.5 to 170 & 68.0 & 12 \\
\hline $\mathrm{Sr}$ & $\mathrm{ppm}$ & $438 \pm 208$ & 47 & 220 to 940 & 4.3 & 12 \\
\hline y & $\mathrm{ppm}$ & $18.2 \pm 25.6$ & 147 & 3.0 to 96 & 32.0 & 12 \\
\hline $2 r$ & $\mathrm{ppm}$ & $71 \pm 44$ & 62 & 27 to 160 & 5.9 & 12 \\
\hline $\mathrm{Nb}$ & $\mathrm{ppm}$ & $4.3 \pm 3.0$ & 69 & 1.3 to 9.3 & 7.2 & 12 \\
\hline Mo & $\mathrm{ppm}$ & $10.3 \pm 10$ & 104 & 1.8 to 36 & 10.0 & 12 \\
\hline$P d$ & ppm & $<3$ & & & & \\
\hline $\mathrm{Ag}$ & $\mathrm{ppm}$ & $<0.2$ & & & & \\
\hline$c d$ & ppm & $\approx 0.3$ & & & & 2 \\
\hline Sn & $\mathrm{ppm}$ & $<7$ & & & & \\
\hline Sb & $\mathrm{ppm}$ & $1.8 \pm 3.7$ & 202 & $0.16 . \pm 13.0$ & 81.3 & 11 \\
\hline Cs & $\mathrm{ppm}$ & $1.3 \pm 1.8$ & 139 & $0.32 \pm 6.2$ & 19.4 & 10 \\
\hline $\mathrm{Ba}$ & $\mathrm{ppm}$ & $950 \pm 1950$ & 106 & $<20$ to 7060 & 353 & 12 \\
\hline La & $\mathrm{ppm}$, & $13.0 \pm 6.9$ & 53 & 2.9 to 28 & 9.7 & 11 \\
\hline $\mathrm{Ce}$. & $\mathrm{ppm}$ & $24.3 \pm 13.5$ & 55 & $\because 6.2$ to 52 & 8.4 & 11 \\
\hline Sm & $\mathrm{ppm}$ & $2.0 \pm 1.3$ & $63:$ & 0.42 : to 4.2 & 10.0 & 11 \\
\hline Eu. & $\mathrm{ppm}$ & $0.55 \pm 0.38$ & 69 & $0.11 \pm 1.2$ & 10.9 & 11 \\
\hline Tb & $\mathrm{ppm}$ & $0.41 \pm 0.24$ & 59 & 0.11 to 0.78 & 7.1 & 11 \\
\hline Dy & $\mathrm{ppm}$ & $2.3 \pm 1.3$ & 54 & 0.55 to 4.3 & 7.8 & 7 \\
\hline Ho & $\mathrm{ppm}$ & $\approx 0.9$ & & & & R.E. \\
\hline$Y b$ & ppm & $1.4 \pm 0.9$ & 63 & $0.38 \pm 3.0$ & 7.9 & $\begin{array}{l}\text { Rat } 10 \\
11\end{array}$ \\
\hline Lu & $\mathrm{ppm}$ & $0.27 \pm 0.13$ & 48 & 0.15 to 0.50 & 3.3 & 11 \\
\hline $\mathrm{Hf}$ & $\mathrm{ppm}$ & $2.2 \pm 1.5$ & 71 & 0.65 to 5.7 & 8.8 & 11 \\
\hline $\mathrm{Ta}$ & $\mathrm{ppm}$ & $0.44 \pm 0.31$ & 70 & 0.092 to 0.90 & 9.8 & 11 \\
\hline W. & $\mathrm{ppm}$ & $1.4 \pm 1.1$ & 81 & 0.39 to. 3.9 & 10.0 & 11 \\
\hline $\mathrm{Pb}$ & $\mathrm{ppm}$ & $61 \pm 158$ & 258 & 5.4 to 560 & 104 & 12 \\
\hline Th & $\mathrm{ppm}$ & $3.5 \pm 3.0$ & 85 & $0.75 \pm 120$ & 16.0 & 11 \\
\hline U & $\mathrm{ppm}$. & $2.7 \pm 0.9$ & 36 & $1.4 \pm 4.4$ & 3.1 & 11 \\
\hline
\end{tabular}

(a) Range factor is the ratio of the highest to lowest value measured.

(b) Relative standard deviation expressed as a percentage of the average value. 
IABLE 4.16. Cobalt to Europium Ratio in Bioshield Concrete

$\begin{array}{lc}\text { WPPSS } & 20.0 \\ \text { Ranch Seco } & 15.0 \\ \text { Bellefonte } & 10.8 \\ \text { Hartsville } & 15.2 \\ \text { Wolf Creek } & 9.7 \\ \text { Palo Verde } & 7.2 \\ \text { Enrico Fermi } & 11.5 \\ \text { Turkey Point } & 10.0 \\ \text { Pathfinder } & 10.0 \\ \text { Humboldt Bay } & 17.0 \\ \text { Average } & 12.6 \pm 4.0(31 \%) \\ \text { Range } & 7.2 \text { to } 20.0 \\ \text { Range Factor } & 2.8\end{array}$

\subsubsection{Concrete Ingredients}

In addition to the whole concrete samples, a selection of concrete ingredients was also collected in order to obtain a better understanding of the origin of the trace elements in the concrete. These ingredients are summarized in Tables 4.17 to 4.20 for cement, coarse aggregate, sand aggregates, and fly ash, respectively. These were retabulated for the Palo Verde, Enrico Fermi, and Hartsville sites respectively on Tables 4.21 through 4.23. In most cases the coarse and fine aggregates are of very similar composition. Since concrete is normally about $75 \%$ aggregate, the aggregate tends to dominate the composition for most elements. A few elements are contributed mainly by the cement. These include $\mathrm{S}, \mathrm{Ca}, \mathrm{Sr}$, and in some cases $\mathrm{Zn}$. The use of coal flyash as a cement substitute has become more common in recent years. Several of the reactor sites included in this study provided fly ash along with other ingredients. For the Hartsville samples, a regression analysis was carried out to determine the relative contribution of each component on an element by element basis. This data gave a good fit to an aggregate component of $73.4 \pm 9.6 \%$, with $19.7 \pm 4.5 \%$ cement and $4.0 \pm 0.5 \%$ fly ash. This is in reasonably good agreement with the engineering specifications for the concrete which require $4.9 \%$ fly ash. The fit is quite good for most elements as shown in Figure 4.2 which gives a plot of the standardized residuals. Although the fly ash is a relatively small fraction of the total concrete by weight it has a disproportionately large influence on the trace element content. This situation is graphically illustrated in Figure 4.3 with the dashed line representing the weight percent contribution of fly ash. All elements except $\mathrm{Ca}, \mathrm{Mn}$, and $\mathrm{Sr}$ plot well above the line, with typical values ranging from 20 to $40 \%$. Elements whose concentrations are more than doubled by the addition of fly ash include 


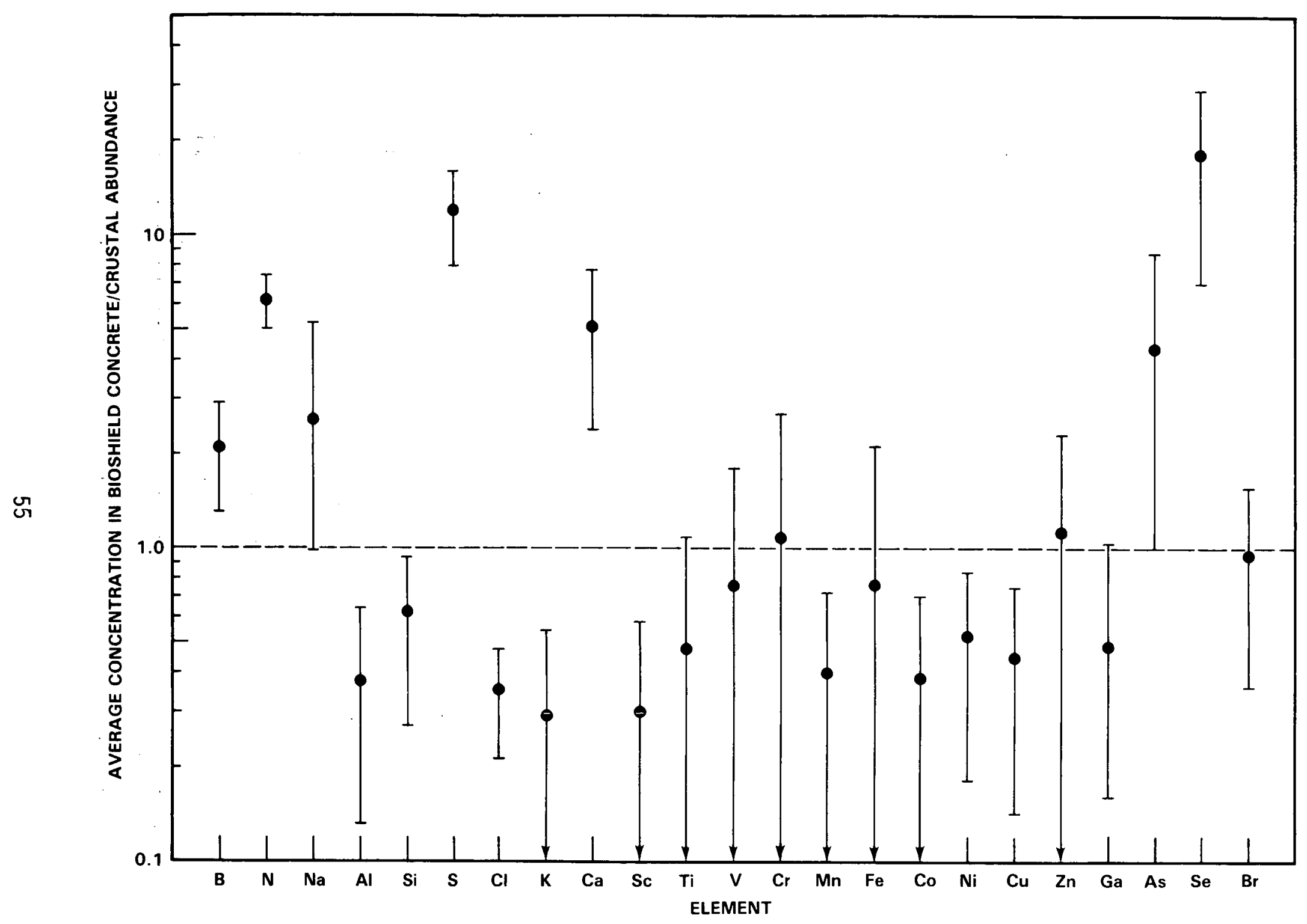

FIGURE 4.1a. Average Elemental Concentrations in Bioshield Concrete Normalized to Average Crustal Abundance 



\section{TABLE 4.17. Chemical Analysis of Cement Used for Bioshield Concrete}

\begin{tabular}{|c|c|c|c|c|c|c|c|c|}
\hline El & nent & WPPSS & Belle Fonte & Hartsville & Wolf Creek & Palo Verde & Enrico Fermi & Susquehanna \\
\hline $\begin{array}{l}\mathrm{Na} \\
\mathrm{Al}\end{array}$ & $\begin{array}{l}\% \\
\%\end{array}$ & $\begin{array}{l}0.076 \\
2.3\end{array}$ & $\begin{array}{l}0.090 \\
2.5\end{array}$ & $\begin{array}{l}0.14 \\
2.4\end{array}$ & $\begin{array}{l}0.25 \\
2.2\end{array}$ & $\begin{array}{l}0.10 \\
2.2\end{array}$ & $\begin{array}{l}0.24 \\
2.6\end{array}$ & $\begin{array}{l}0.20 \\
2.2\end{array}$ \\
\hline $\mathrm{Si}$ & $\%$ & 11.0 & 10.4 & 11.4 & 10.9 & 10.0 & 10.9 & 10.7 \\
\hline $\mathrm{P}$ & $\%$ & $<0.6$ & $<0.6$ & $<0.6$ & $<0.7$ & $<0.6$ & $<0.6$ & $<0.6$ \\
\hline S & $\%$ & 1.4 & 1.3 & 0.88 & 1.0 & 1.6 & 1.1 & 1.1 \\
\hline K & $\%$ & 0.56 & 0.49 & 0.40 & 0.27 & 22 & 0.7 & 60 \\
\hline $\mathrm{Ca}$ & $\%$ & 41.6 & 45.5 & 46.1 & 46.0 & 48.5 & 45.3 & 46.1 \\
\hline Sc & $\mathrm{ppm}$ & 2.99 & 4.3 & 3.5 & 3.9 & 4.3 & 4.2 & 3.1 \\
\hline $\mathrm{Ti}$ & $\mathrm{ppm}$ & 1100 & 960 & 850 & 1060 & 1810 & 1210 & 1040 \\
\hline v & $\mathrm{ppm}$ & 28 & 44 & 41 & 51 & 43 & 43 & 36 \\
\hline $\mathrm{Cr}$ & $\mathrm{ppm}$ & 66 & 52 & 28 & 72 & 105 & 67 & 272 \\
\hline Mn & $\mathrm{ppm}$ & 1090 & 280 & 191 & 658 & 347 & 414 & 616 \\
\hline $\mathrm{Fe}$ & $\%$ & 2.17 & 1.86 & 2.00 & 3.35 & 2.12 & 1.78 & 2.29 \\
\hline Co & $\mathrm{ppm}$ & 29 & 7.0 & 5.3 & 4.4 & 9.9 & 5.5 & 7.8 \\
\hline $\mathrm{Ni}$ & $\mathrm{ppm}$ & 32 & 32 & 34 & 43 & 62 & 36 & 108 \\
\hline $\mathrm{Cu}$ & $\mathrm{ppm}$ & 77 & 72 & 27 & 17 & 85 & 18 & 43 \\
\hline $\mathrm{Zn}$ & $\mathrm{ppm}$ & 988 & 230 & 56 & 33 & 470 & 37 & 31 \\
\hline Ga & $\mathrm{ppm}$ & 8.0 & 6.3 & 5.1 & 7.1 & 5.8 & 7.1 & 7.5 \\
\hline As & $\mathrm{ppm}$ & 2.9 & 8.4 & 6.5 & 12.5 & 22 & 6.8 & 5.5 \\
\hline $\mathrm{Se}$ & $\mathrm{ppm}$ & 1.6 & 0.62 & 0.52 & 1.1 & 1.3 & $<0.2$ & 1.7 \\
\hline $\mathrm{Br}$ & $\mathrm{ppm}$ & $<0.3$ & 0.56 & 0.42 & $<0.4$ & 0.73 & $<0.4$ & $<0.2$ \\
\hline $\mathrm{Rb}$ & $\mathrm{ppm}$ & 14 & 18 & 12 & 7.5 & 16 & 22 & 28 \\
\hline $\mathrm{Sr}$ & $\mathrm{ppm}$ & 853 & 1140 & 789 & 2210 & 460 & 205 & 1500 \\
\hline Y & $\mathrm{ppm}$ & 9.0 & 15 & 8.6 & 9.7 & 11 & 15 & 7.6 \\
\hline $\mathrm{Zr}$ & $\mathrm{ppm}$ & 17 & $<3$ & $<3$ & $<4$ & 76 & 55 & 32 \\
\hline $\mathrm{Nb}$ & $\mathrm{ppm}$ & 4.1 & 3.0 & 3.1 & 2.8 & 7.1 & 3.9 & 2.2 \\
\hline Mo & $\mathrm{ppm}$ & 4.1 & $<1$ & $<1$ & $<1.5$ & 4.7 & 5.0 & 20 \\
\hline $\mathrm{Ag}$ & $\mathrm{ppm}$ & $<0.3$ & 0.2 & $<0.5$ & $<0.3$ & $<0.7$ & $<0.4$ & $<0.4$ \\
\hline $\mathrm{Sb}$ & $\mathrm{ppm}$ & 3.8 & 0.62 & 0.48 & 0.61 & 1.29 & 0.59 & 0.63 \\
\hline Cs & $\mathrm{ppm}$ & $<4$ & 1.2 & $<5$ & 1.4 & $<3$ & $<4$ & 1.32 \\
\hline $\mathrm{Ba}$ & $\mathrm{ppm}$ & 514 & 134 & 159 & 2120 & 210 & 266 & 128 \\
\hline La & $\mathrm{ppm}$ & 12 & 18 & 11 & 13 & 17.8 & 16 & 10.8 \\
\hline $\mathrm{Ce}$ & $\mathrm{ppm}$ & 22 & 28 & 20 & 25 & 29 & 26 & 21 \\
\hline Sm & ppm & 1.7 & 3.2 & 1.7 & 2.3 & 2.4 & 2.5 & 1.6 \\
\hline Eu & $\mathrm{ppm}$ & 0.38 & 0.64 & 0.38 & 0.50 & 0.58 & 0.51 & 0.33 \\
\hline $\mathrm{Tb}$ & $\mathrm{ppm}$ & 0.27 & 0.51 & 0.29 & 0.36 & 0.35 & 0.38 & 0.26 \\
\hline Dy & $\mathrm{ppm}$ & 1.6 & 1.4 & & & & & \\
\hline$Y b$ & $\mathrm{ppm}$ & 0.96 & & 1.0 & 1.3 & 1.9 & 1.4 & 0.87 \\
\hline Lu & $\mathrm{ppm}$ & 0.40 & 0.31 & 0.18 & 0.30 & 1.13 & 0.34 & 0.18 \\
\hline $\mathrm{Hf}$ & ppm & 1.6 & 1.6 & 1.2 & 3.0 & 2.2 & 1.9 & 1.1 \\
\hline $\mathrm{Ta}$ & ppm & 0.28 & 0.32 & 0.26 & 0.37 & 0.63 & 0.35 & 0.26 \\
\hline$W$ & $\mathrm{ppm}$ & 1.4 & 0.54 & 0.47 & 1.0 & 0.72 & 0.86 & 3.3 \\
\hline $\mathrm{Pb}$ & $\mathrm{ppm}$ & 6.9 & 17 & $<3$ & $<3$ & 33 & $<3$ & 20 \\
\hline Tb & $\mathrm{ppm}$ & 3.5 & 3.8 & 2.5 & 4.1 & 3.2 & 3.3 & 2.6 \\
\hline U & $\mathrm{ppm}$ & 2.2 & 2.8 & 1.9 & 3.5 & 1.5 & 6.0 & 1.7 \\
\hline
\end{tabular}


TABLE 4.18. Chemical Analysis of Coarse Aggregate for Bioshield Concrete



Note: Number in parenthesis indicate number of samples analyzed at each site. Numbers in the table are averages and standard deviations for that number of samples. 
TABLE 4.19. Chemical Analysis of Sand Aggregate for Bioshield Concrete

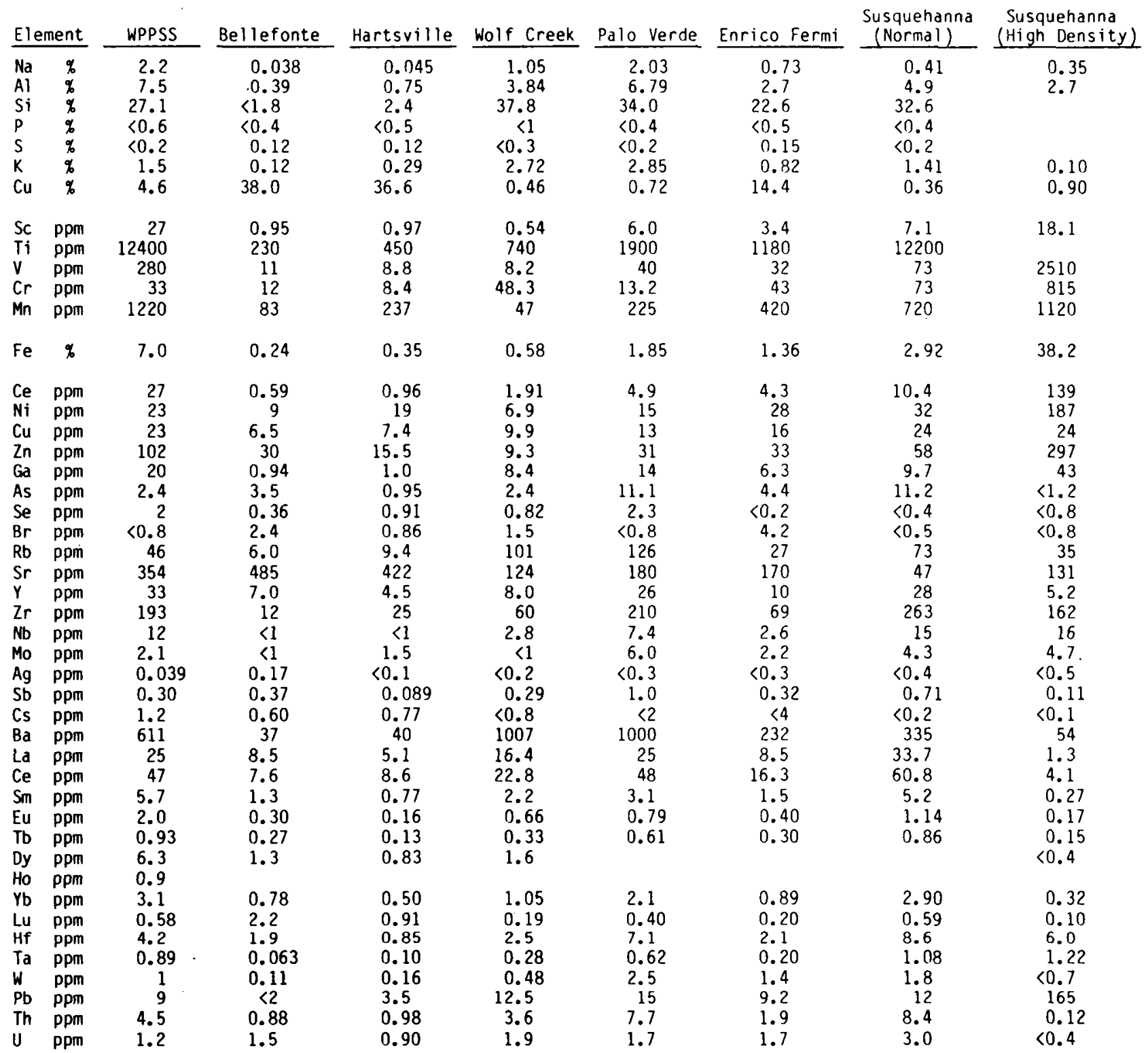


TABLE 4.20. Chemical Analysis of Fly Ash Used in Bioshield Concrete Element Bellefonte Hartsville Enrico Fermi Palo Verde

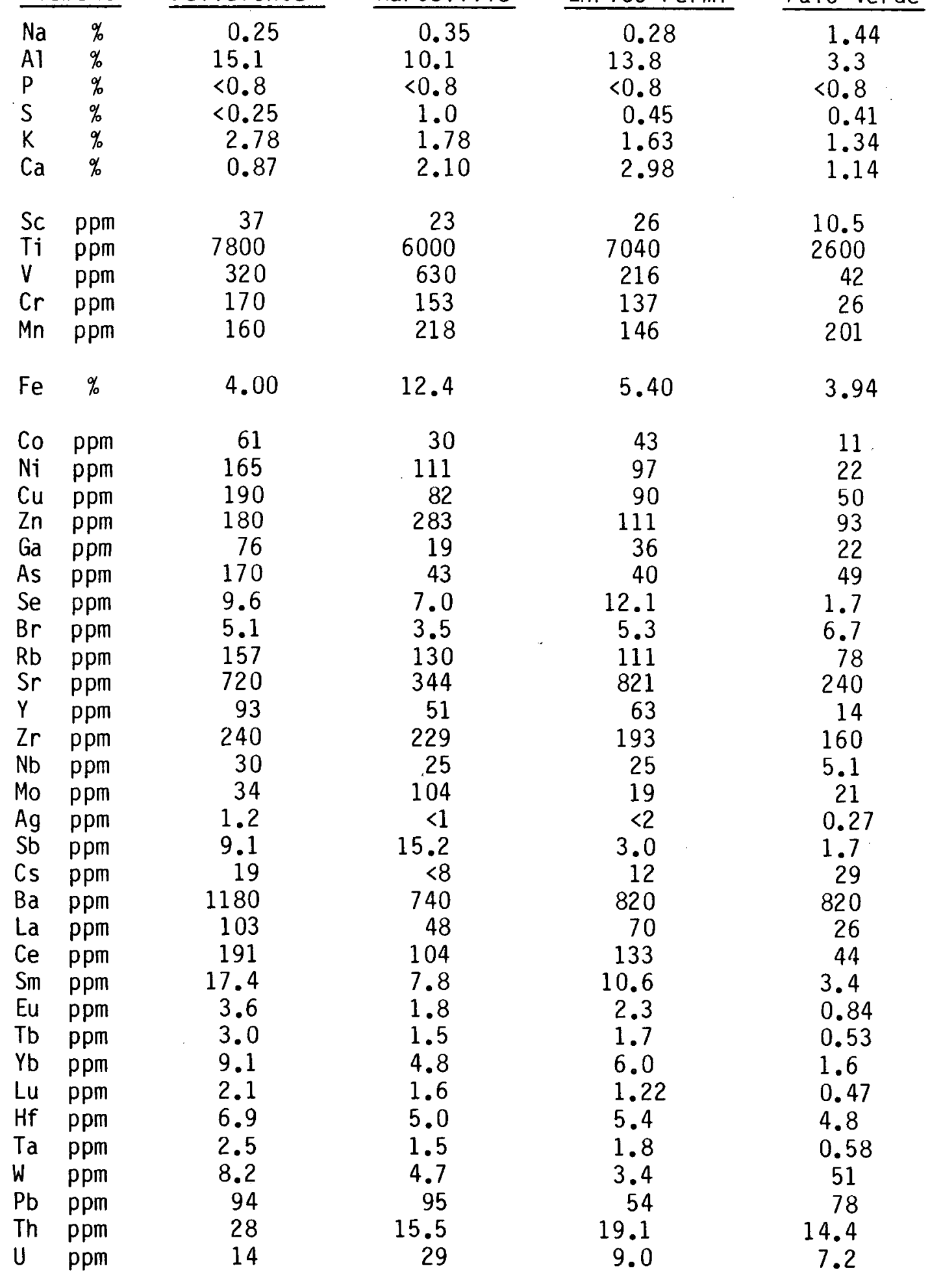


TABLE 4.21. Concrete Ingredients (Palo Verde) Elemental Concentrations

\begin{tabular}{|c|c|c|c|c|c|c|}
\hline \multicolumn{2}{|c|}{ El ement } & \multirow{2}{*}{$\frac{\text { Concrete }}{18200}$} & \multirow{2}{*}{$\begin{array}{c}\begin{array}{c}\text { Coarse } \\
\text { Aggregate }\end{array} \\
20700\end{array}$} & \multirow{2}{*}{$\frac{\text { Sand }}{20300}$} & \multirow{2}{*}{$\frac{\text { Fly Ash }}{14400}$} & \multirow{2}{*}{$\frac{\text { Cement }}{1000}$} \\
\hline $\mathrm{Na}$ & ppm & & & & & \\
\hline $\mathrm{Al}$ & $\%$ & 6.1 & 7.1 & 6.8 & 3.3 & 2.2 \\
\hline $\mathrm{S}$ & $\%$ & 0.27 & $<0.2$ & $<0.2$ & $<0.41$ & 1.6 \\
\hline$k$ & $\%$ & 2.5 & 2.9 & 2.9 & 1.34 & 0.53 \\
\hline $\mathrm{Ca}$ & $\%$ & 9.2 & 0.98 & 0.72 & 1.14 & 48.5 \\
\hline Sc & $\mathrm{ppm}$ & 5.3 & 5.0 & 6.0 & 10.5 & 4.3 \\
\hline Ti & $\mathrm{ppm}$ & 2100 & 2000 & 1900 & 1600 & 1810 \\
\hline v & $\mathrm{ppm}$ & 34 & 30 & 40 & 42 & 43 \\
\hline $\mathrm{Cr}$ & $\mathrm{ppm}$ & 47 & 50 & 13.2 & 26 & 105 \\
\hline $\mathrm{Mn}$ & $\mathrm{ppm}$ & 290 & 384 & 225 & 201 & 347 \\
\hline $\mathrm{Fe}$ & $\%$ & 1.9 & 1.86 & 1.85 & 3.94 & 2.12 \\
\hline Co & $\mathrm{ppm}$ & 5.6 & 3.98 & 4.9 & 11 & 9.9 \\
\hline $\mathrm{Ni}$ & $\mathrm{ppm}$ & 30 & 9.7 & 15 & 22 & 62 \\
\hline $\mathrm{Cu}$ & $\mathrm{ppm}$ & 28 & 15.5 & 13 & 50 & 85 \\
\hline $\mathrm{Zn}$ & $\mathrm{ppm}$ & 90 & 43 & 31 & 93 & 470 \\
\hline Ga & $\mathrm{ppm}$ & 13 & 13 & 41 & 22 & 5.8 \\
\hline As & $\mathrm{ppm}$ & 2.0 & 8.6 & 11.1 & 49 & 22 \\
\hline $\mathrm{Br}$ & $\mathrm{ppm}$ & 2.0 & 0.95 & $<0.8$ & 6.7 & 0.73 \\
\hline $\mathrm{Rb}$ & $\mathrm{ppm}$ & 170 & 109 & 126 & 78 & 16 \\
\hline $\mathrm{Sr}$ & $\mathrm{ppm}$ & 220 & 131 & 180 & 240 & 460 \\
\hline Y & $\mathrm{ppm}$ & 96 & 39 & 26 & 14 & 11 \\
\hline $\mathrm{Zn}$ & $\mathrm{ppm}$ & 160 & 198 & 210 & 160 & 76 \\
\hline $\mathrm{Nb}$ & $\mathrm{ppm}$ & 9.2 & 12.5 & 7.4 & 5.1 & 7.1 \\
\hline $\mathrm{Sb}$ & $\mathrm{ppm}$ & 1.4 & 1.0 & 1.0 & 21 & 1.29 \\
\hline $\mathrm{Ba}$ & $\mathrm{ppm}$ & 885 & 825 & 1000 & 820 & 210 \\
\hline Sm & $\mathrm{ppm}$ & 3.9 & 4.8 & 3.1 & 3.4 & 2.4 \\
\hline Eu & $\mathrm{ppm}$ & 0.77 & 0.88 & 0.79 & 0.84 & 0.58 \\
\hline $\mathrm{Ta}$ & $\mathrm{ppm}$ & 0.90 & 0.92 & 0.62 & 0.58 & 0.63 \\
\hline W & $\mathrm{ppm}$ & 3.9 & 2.0 & 2.5 & 51 & 0.72 \\
\hline $\mathrm{Pb}$ & $\mathrm{ppm}$ & 34 & 15.5 & 15 & 78 & 33 \\
\hline Th & $\mathrm{ppm}$ & 12 & 13.8 & 7.7 & 14.4 & 3.2 \\
\hline U & $\mathrm{ppm}$ & 2.7 & 3.4 & 1.7 & 7.2 & 1.5 \\
\hline
\end{tabular}


TABLE 4.22. Concrete Ingredients (Enrico Fermi) Elemental Concentrations

\begin{tabular}{|c|c|c|c|c|c|}
\hline \multicolumn{2}{|c|}{ Element } & \multirow{2}{*}{$\frac{\text { Concrete }}{5220}$} & \multirow{2}{*}{$\frac{\text { Sand }}{7300}$} & \multirow{2}{*}{$\frac{\text { Fly Ash }}{2800}$} & \multirow{2}{*}{$\frac{\text { Cement }}{2400}$} \\
\hline $\mathrm{Na}$ & $\mathrm{ppm}$ & & & & \\
\hline$A 1$ & $\%$ & 2.0 & 2.7 & 13.8 & 2.6 \\
\hline$S$ & $\%$ & 0.42 & 0.15 & 0.45 & 1.1 \\
\hline K & $\%$ & 0.60 & 0.82 & 1.63 & 0.70 \\
\hline $\mathrm{Ca}$ & $\%$ & 17.5 & 14.4 & 2.98 & 45.3 \\
\hline Sc & $\mathrm{ppm}$ & 3.0 & 3.4 & 26 & 4.2 \\
\hline $\mathrm{Ti}$ & $\mathrm{ppm}$ & 1030 & 1180 & 7040 & 1210 \\
\hline V & $\mathrm{ppm}$ & 32 & 32 & 216 & 43 \\
\hline $\mathrm{Cr}$ & $\mathrm{ppm}$ & 27 & 43 & 137 & 67 \\
\hline Mn & $\mathrm{ppm}$ & 270 & 420 & 146 & 414 \\
\hline $\mathrm{Fe}$ & $\%$ & 1.1 & 1.36 & 5.40 & 1.78 \\
\hline Co & $\mathrm{ppm}$ & 3.8 & 4.3 & 43 & 5.5 \\
\hline $\mathrm{Ni}$ & $\mathrm{ppm}$ & 14 & 28 & 97 & 36 \\
\hline $\mathrm{Cu}$ & $\mathrm{ppm}$ & 10 & 16 & 90 & 18 \\
\hline $\mathrm{Zn}$ & $\mathrm{ppm}$ & 33 & 33 & 111 & 37 \\
\hline Ga & $\mathrm{ppm}$ & 5.5 & 6.3 & 36 & 7.1 \\
\hline As & $\mathrm{ppm}$ & 4.9 & 4.4 & 40 & 6.8 \\
\hline $\mathrm{Br}$ & $\mathrm{ppm}$ & 5.6 & 4.2 & 5.3 & $<0.4$ \\
\hline $\mathrm{Rb}$ & $\mathrm{ppm}$ & 22 & 27 & 111 & 22 \\
\hline $\mathrm{Sr}$ & $\mathrm{ppm}$ & 310 & 170 & 821 & 205 \\
\hline Y & $\mathrm{ppm}$ & 6.7 & 10 & 63 & 15 \\
\hline $\mathrm{Zr}$ & $\mathrm{ppm}$ & 52 & 69 & 193 & 55 \\
\hline $\mathrm{Nb}$ & $\mathrm{ppm}$ & 1.8 & 2.6 & 25 & 3.9 \\
\hline $\mathrm{Sb}$ & $\mathrm{ppm}$ & 0.5 & 2.2 & 3.0 & 0.59 \\
\hline $\mathrm{Ba}$ & $\mathrm{ppm}$ & 706 & 232 & 820 & 266 \\
\hline $\mathrm{Sm}$ & ppm & 1.7 & 1.5 & 10.6 & 2.5 \\
\hline Eu & ppm & 0.34 & 0.40 & 2.3 & 0.51 \\
\hline $\mathrm{Ta}$ & ppm & 0.24 & 0.30 & 1.8 & 0.35 \\
\hline W & $\mathrm{ppm}$ & 0.6 & 1.4 & 3.4 & 0.86 \\
\hline $\mathrm{Pb}$ & ppm & 5.9 & 9.2 & 54 & $<3$ \\
\hline Th & $\mathrm{ppm}$. & 2.1 & 1.9 & 19.1 & 3.3 \\
\hline U & $\mathrm{ppm}$ & 3.0 & 1.7 & 9.0 & 6.0 \\
\hline
\end{tabular}


TABLE 4.23. Concrete Ingredients (Hartsville)

Elemental Concentrations

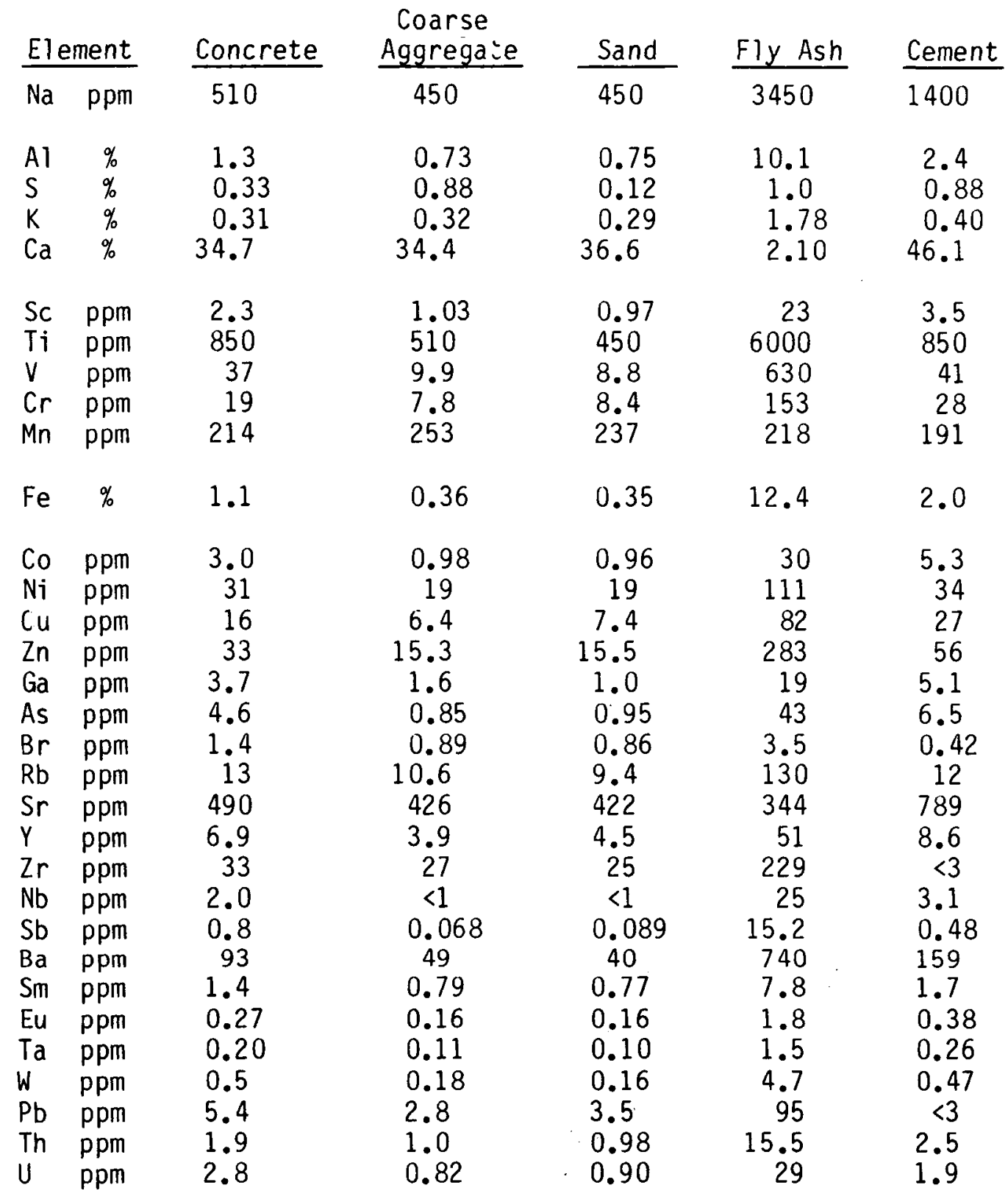


TABLE 4.24. Weighted Least Squares Fit to Concentrations of Elements in Hartsville Bioshield Concrete

Percent Contribution

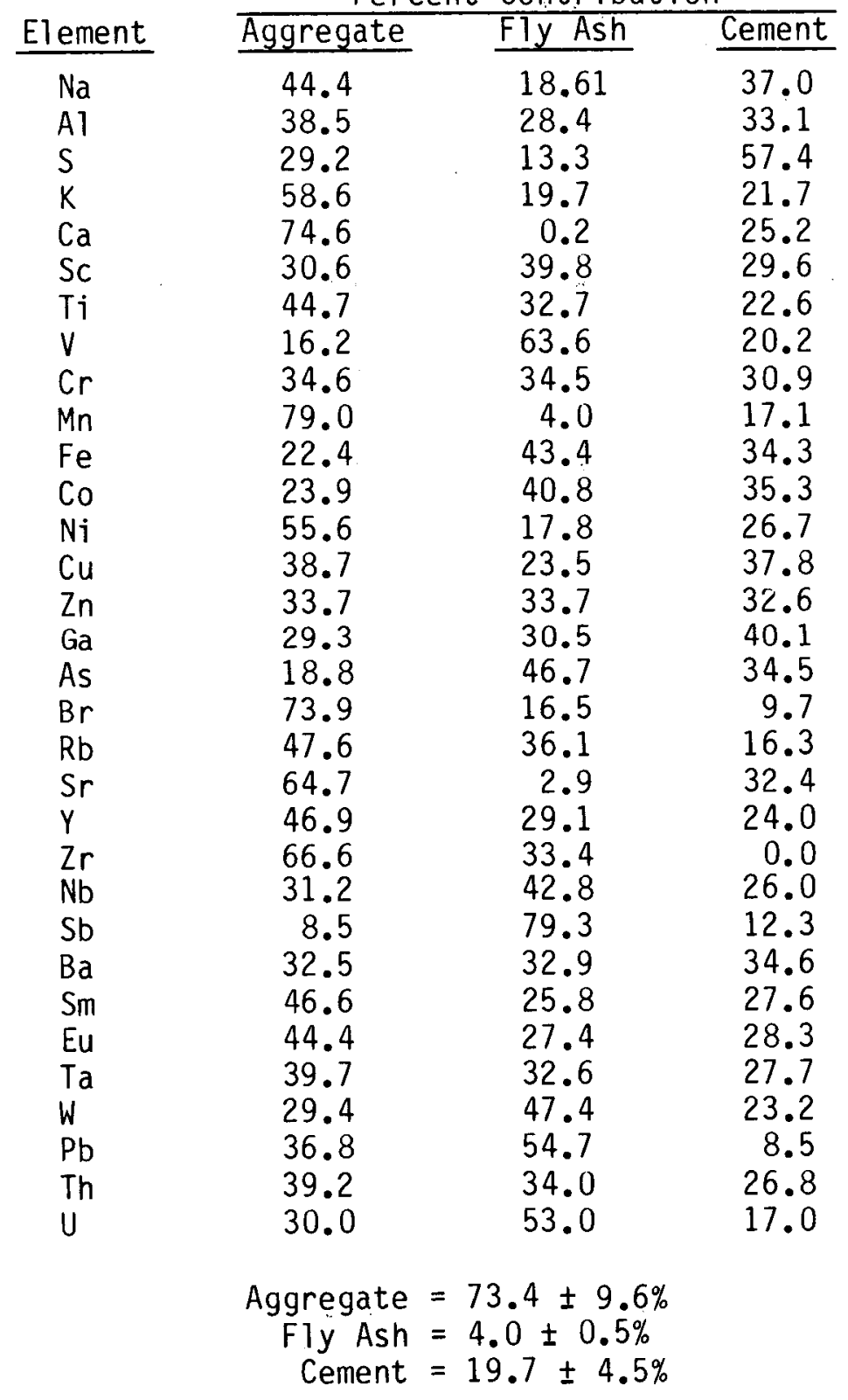




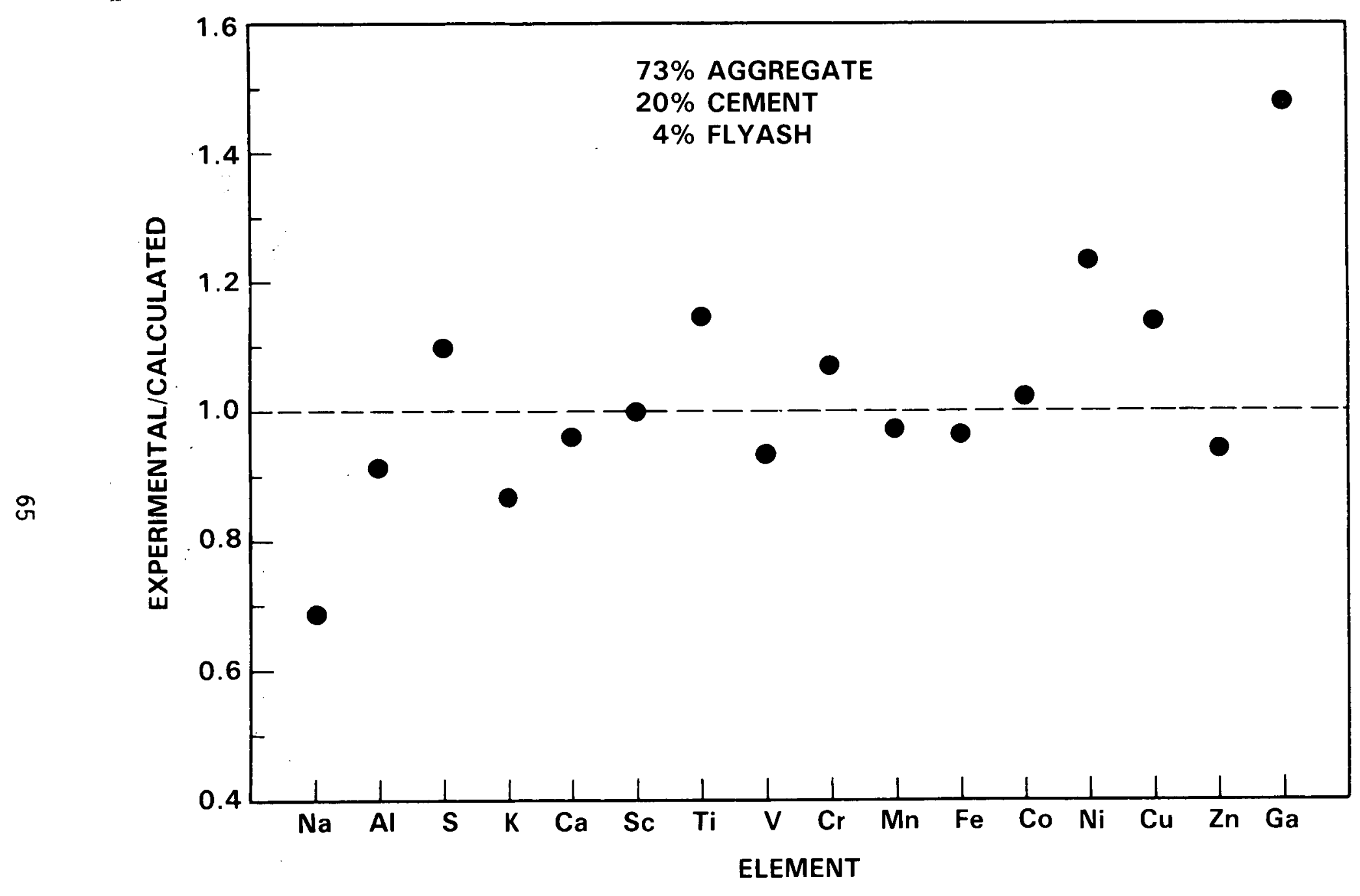

FIGURE 4.2a. Weighted Fit of Three Components to Concentration of 32 Elements for Hartsville Bioshield Concrete 


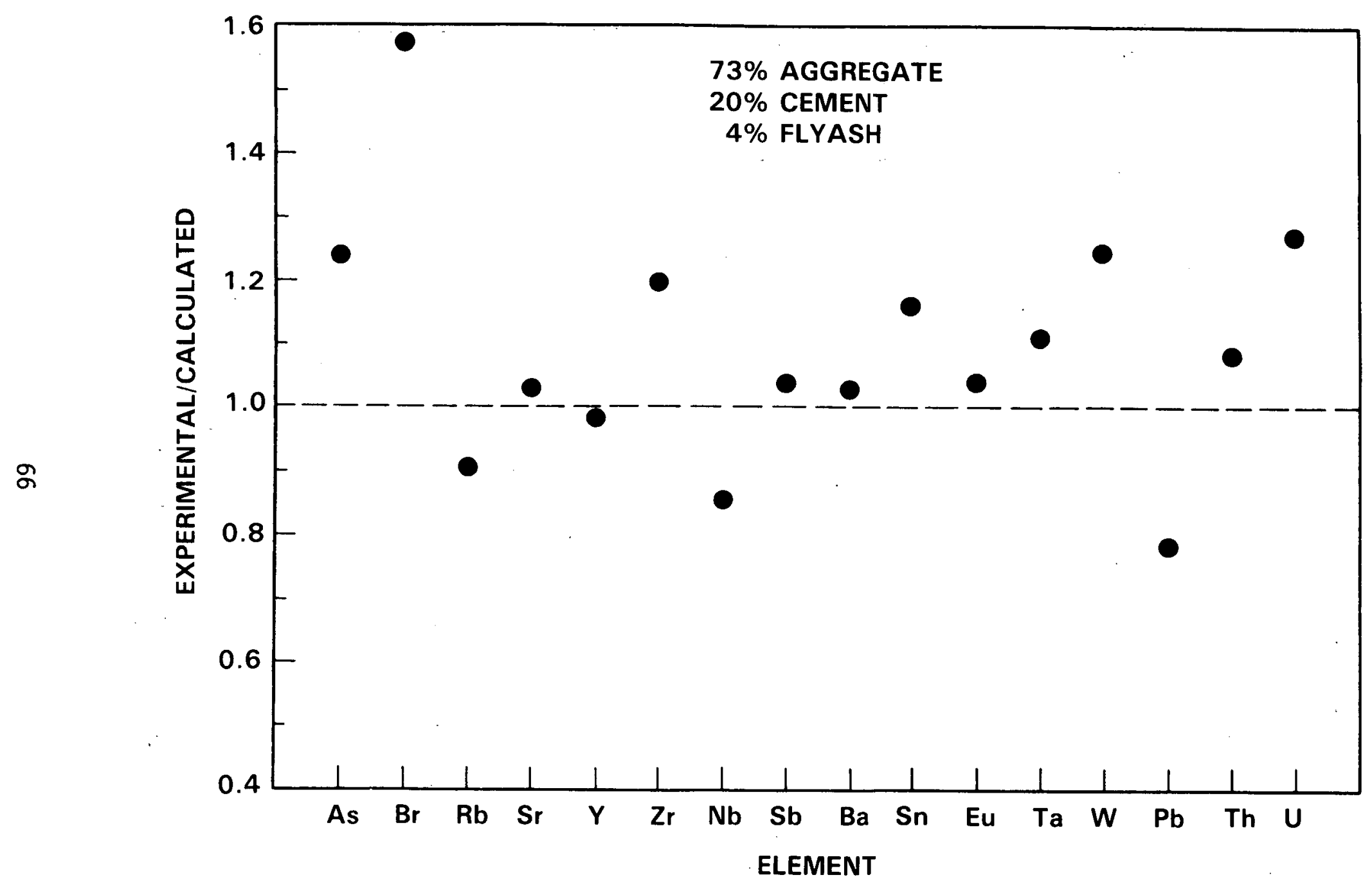

FIGURE 4.2a. (contd) 


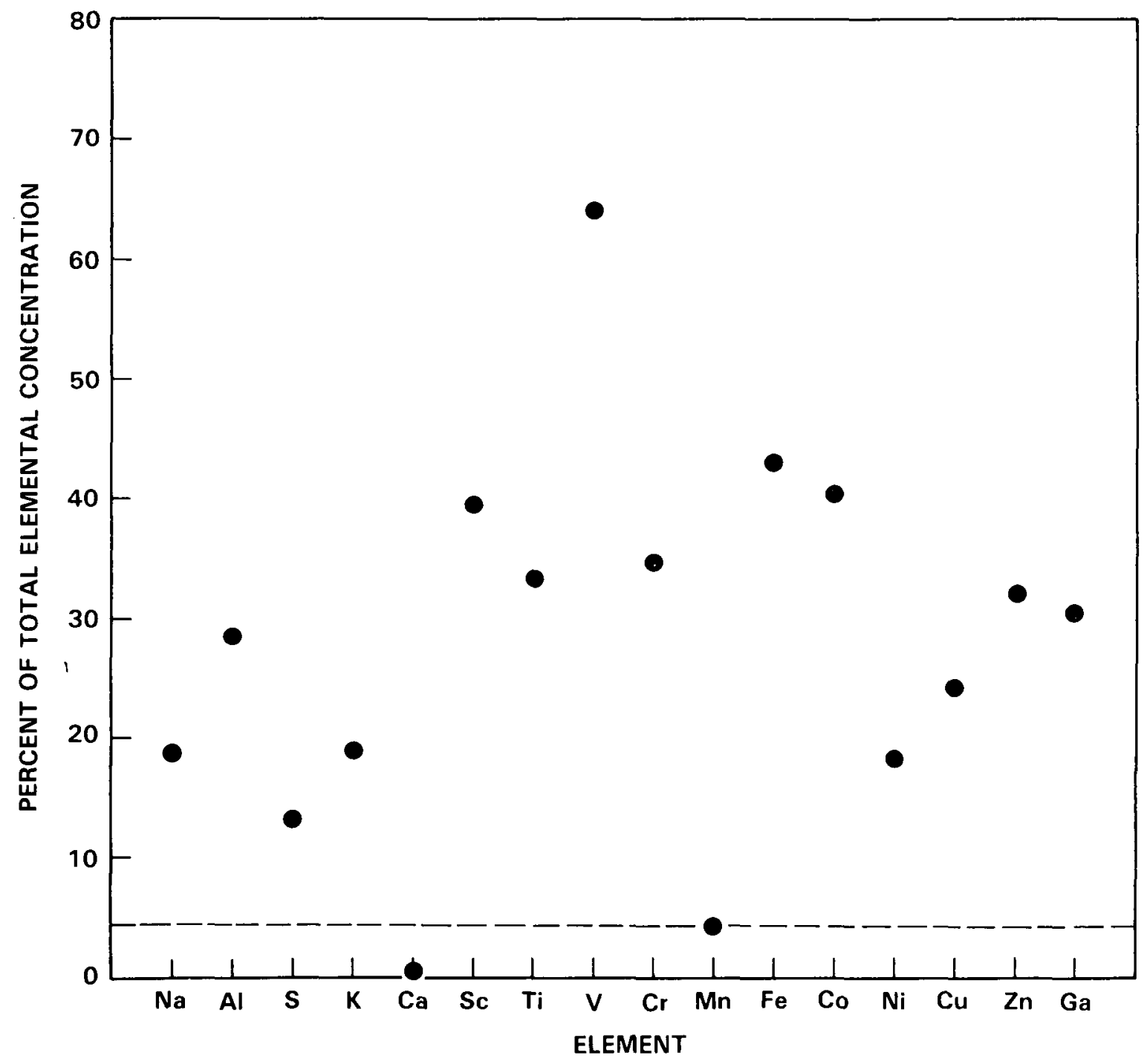

FIGURE 4.3a. Contribution of Fly Ash to Elemental Concentrations of Hartsville Bioshield Concrete

$\mathrm{V}, \mathrm{Sb}, \mathrm{Pb}$, and $\mathrm{U}$. This is a relatively minor change, falling well within the normal range of variability of those elements anyway. Addition of fly ash to cement does not therefore appear to cause any unusual problems with regard to activation products, provided the proportion added is kept small as was the case with the Hartsville samples. 


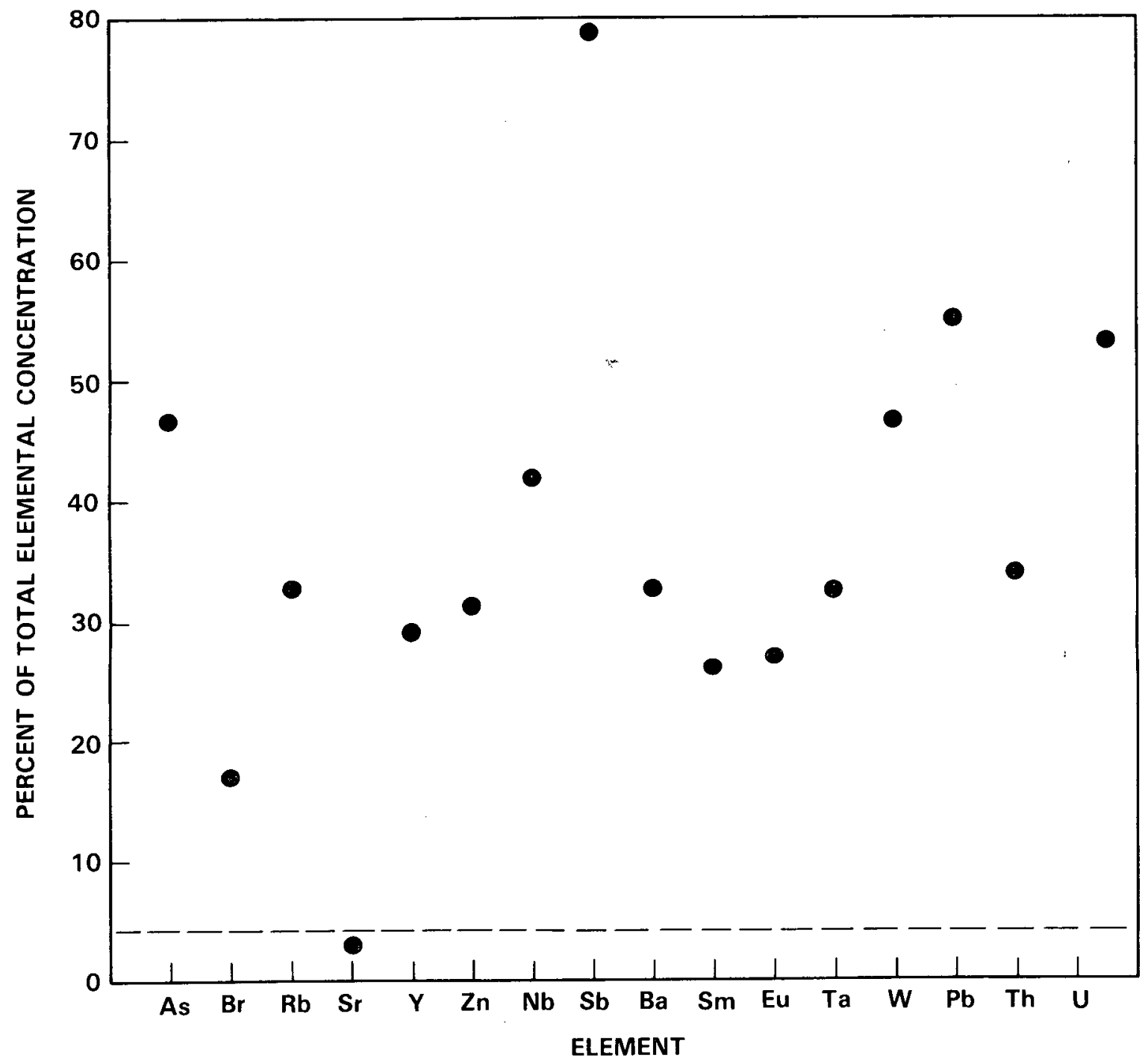

FIGURE 4.3a. (contd) 


\subsection{ACTIVATION CALCULATIONS}

\subsection{CALCULATION METHOD}

In order to fully determine the expected levels of activation products in the various construction materials previously discussed, a suitable computer model was required. Early in the program it was determined that the available software such as the ORIGEN code used by Smith, Konzek, and Kennedy (1978) in their work was at the same time over-designed for the task and inflexible in its application to long lived activation products for which a limited data base was available. It was thus decided instead to develop a series of simpler codes specifically designed for this purpose. An additional goal was the inclusion of multi-group fast neutron reactions. The program was designed to be run on PDP-11 minicomputers in a fully interactive fashion. This approach proved very successful and was eventually adapted to a VAX/11-780 system in order to obtain adequate computing speed for the large number of cases considered. This family of programs consists of three main programs to generate flux, composition, and nuclear data libraries, a series of isotope selection files structured to match the isotope with the correct cross-section library, and a main program to carry out the activation calculation itself and store the results on a disk file. A full documentation and listings of the family of programs are included in the Appendix.

A11 nuclear parameters are tabulated in a series of libraries created by code NUCLIB. Five different kinds of libraries can be created. These include $N-\gamma, N-2 N, N-P, N-D$, and $N-\alpha$ reactions in separate libraries thus allowing flexibility to evaluate the relative importance of those different reaction modes for the same product isotope if desired. Each block of library entries contains information on the type of reaction, the mass of the product isotope, the number of elements in the production chain, the isotopic abundances, halflives, fission yields, production cross-sections and matching resonance integrals as well as the corresponding burnup cross-sections for each isotope having a significant contribution to the final product isotope. In constructing these production chains, it was necessary to make a subjective decision on the size of the chain based on available cross-section data (or lack of it). For most isotopes, only thermal neutron capture or resonance capture was important. These were contained in the $\mathrm{N}-\gamma$ library. These include ${ }^{3} \mathrm{~T},{ }^{14} \mathrm{C}$ ${ }^{60} \mathrm{Co}, 63_{\mathrm{Ni}},{ }^{81} \mathrm{Kr},{ }^{90} \mathrm{Sr}{ }_{94} \mathrm{Nb}^{99} \mathrm{Tc}, 108 \mathrm{~m}_{\mathrm{Ag}}, 110 \mathrm{~m} \mathrm{Ag}, 145 \mathrm{Pm}, 151_{\mathrm{Sm}}, 152 \mathrm{Eu}, 154 \mathrm{Eu}$, ${ }^{155} \mathrm{Eu}, 166 \mathrm{~m}_{\mathrm{Ho}},{ }^{138} 8_{\mathrm{Hf}}, 233_{\mathrm{U}},{ }^{236 \mathrm{U}}$, and ${ }^{239} \mathrm{Pu}$. The other four libraries contained in addition to the $\mathrm{N}-\mathrm{r}$ information, an excitation function for the appropriated fast neutron reaction. These cross-sections were included in $0.5 \mathrm{MeV}$ ipfremepts from 0 tg $15 \mathrm{Mgl}$. I gotopes tabulated in the N-2N library

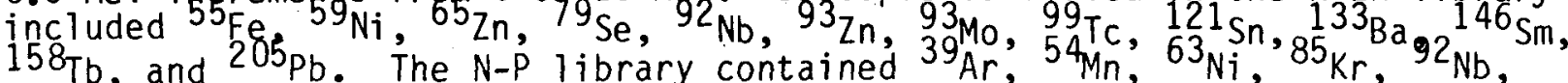


${ }^{93} \mathrm{Zr},{ }^{106} \mathrm{Pd},{ }^{121} \mathrm{Sn},{ }^{134} \mathrm{Cs},{ }^{135} \mathrm{Cs},{ }^{137} \mathrm{Cs}$, and ${ }^{155} \mathrm{Eu}$. The only $\mathrm{N}-\mathrm{D}$ reaction of importance was that producing ${ }^{53} \mathrm{Mn}$. The $\mathrm{N}-\alpha$ library contained only ${ }^{36} \mathrm{Cl},{ }^{55} \mathrm{Fe}$, $85 \mathrm{Kr}$, and $93 \mathrm{Zr}$.

A second program, FLUXI was used to create files containing the reactor conditions including temperature, thermal neutron flux, epithermal flux, and fast flux in thirty energy groups up to $15 \mathrm{MeV}$. This data was then permanently stored on a disk file. It was thus possible to calculate activation in various parts of the reactor by simply using different flux files for each set of calculations.

A third program, COMPOS, was used to assemble files of composition information on different materials. This program in turn references a master data file containing fifty element names together with their atomic number and atomic weights. Composition files were created for several average representative materials including type $304 \mathrm{~L}$ stainless steel, carbon steel, concrete, and rebar.

Files created in the above described manner were then available for editing and updating as more information became available. They could be combined in the appropriate order to carry out activation calculations, via code ACTIV. Code ACTIV performed in the following manner. The composition file was first requested and assigned, the flux file was then requested, opened and read. The thermal and epithermal fluxes were read, the epithermal flux converted to flux per unit lethargy and a cadmium ratio computed. The temperature was read and the fast flux input into an array. The remaining part of the calculation was carried out automatically. The first groups of isotopes were selected in sequence, with the matching library file opened, rewound in each case, and the nuclear information input. For each case, the composition file was rewound, the appropriate chemical elements located and input. A second pass was required to obtain the correct data for $T h$ and $U$ in order to compute a fission contribution. Depending upon reaction type, several indices were adjusted to allow selection of the appropriate element and isotope combinations during the actual activation calculation. The activation calculation itself was done by repeated calls to subroutine NCAP. NCAP is basically an isotope production and depletion routine including fission, multiple neutron capture and fast neutron reactions. Thermal cross-sections are temperature-corrected from the $2200 \mathrm{~m} / \mathrm{s}$ value. Production and depletion is done by a repetitive numerical integration of atoms produced at all points in the chain versus atoms lost to decay or burnup, in 3 day increments for 30 years with results printed for 1 year. intervals. This iterative method is reasonably accurate provided there is not a major competition between beta decay and burnup of intermediate products. In that case, beta decay is selected first. This could result in a minor error due to the relatively coarse mesh size. This approach is also rather costly in terms of computation time while using very small amounts of memory, thus making is suitable for use on small low cost computers. Computation speed was quite 
satisfactory on the VAX system averaging only a few seconds per isotope. This also resulted in very minimal computer costs. In order to verify the accuracy of the method, a comparison was made with a code ORIGEN calculation for several cases with common data bases. Results agreed to within a few percent.

\subsection{CROSS-SECTION SELECTION}

In this work, a careful review was made of all available information in order to construct the most reliable cross-section data base. This was checked and updated several times before the final calculations were undertaken. Reliable cross-section information for all isotopes of interest, both stable and radioactive, has in the past been rather difficult to obtain. This situation has improved markedly in the last few years particularly for thermal neutron capture cross-sections. Resonance integral information is generally unavailable for isotopes with several isomeric states. The situation is particularly true for fast neutron reactions; however, this is a very minor problem since they contribute a negligible amount to the activation products inventory.

\subsubsection{N-Y-Thermal}

Several sources of thermal neutron cross-section information were available. These included the Seventh Edition of the Table of Isotopes, (Browne, Dairiki and Doebler 1978), the Twelfth Edition of the G.E. Chart of the Nuclides (Walker, Kirouac and Rourke 1977), and various publications from the Brookhaven National Neutron Cross-Section Center such as Mughabghab, Divadeenam and Holden (1981). In general, satisfactory production cross-section information was available for all important isotopes. Information on burnup crosssections is relatively scarce and does represent a minor area of uncertainty since burnup can be important, particularly in the high flux region where the shroud is located.

\subsection{2 $\mathrm{N}-\gamma$-Epithermal}

Epithermal cross-sections (resonance integrals) were taken from the same source as the thermal cross-sections. In some cases only the total resonance integral was available for several isomeric states. In that case it was arbitrarily assumed that the resonance integral distributed between isomers in the same manner as the thermal cross-sections. In cases where no resonance integral was listed, a $1 / V$ contribution of 0.45 times the thermal cross-section was automatically included in the cross-section library as the default. The resonance integral can be an important contributor to the total activation even for the minimal $1 / \mathrm{V}$ case since there are regions of the reactor where the cadmium ratio is less than unity. 


\subsubsection{Fast Neutron Reactions}

Fast neutron reaction data is in many cases not available for the appropriate long-lived isotopes. In order to avoid this difficulty, the computer code THRES2 (Pearlstein 1973, 1975) was obtained from the National Neutron Cross-Section Center to calculate fast neutron excitation functions. THRES2 is a semi-empirical code which uses well-measured excitation functions combined with known nuclear reaction systematics to compute unknown cross-sections for up to 19 different reaction types for product isotopes with atomic numbers in the region $Z=21$ to $Z=83$. This code has been demonstrated to be reasonably successful at predicting accurate excitation functions, provided the product nuclei are not too far from stability. A further limitation is the inability of the code to predict independent isomeric yields. This could in principle be done on the basis of spin selection factors, however, that was not necessary for any of the isotopes considered in this work. Only a few isotopes of importance lie outside the atomic number range covered by THRES2. These included ${ }^{39} \mathrm{Ar},{ }^{36} \mathrm{Cl},{ }^{14} \mathrm{C},{ }^{10} \mathrm{Be}$, and ${ }^{3} \mathrm{~T}$. Appropriate experimental data was available in the open literature for everything except $10_{\mathrm{Be}}$. Code THRES2 produces cross-section data in $0.5 \mathrm{MeV}$ intervals from 0 to $20 \mathrm{MeV}$, making it very suitable for use in the activation calculations in this work.

\subsection{NEUTRON FLUX INFORMATION}

Thermal and epithermal neutron flux information used in this work was taken from the ANISN calculations carried out by Smith, Konzek and Kennedy (1978) and 0ak et al. (1980). That information was provided in its original form by the authors of those reports. The data is shown on Figure 5.1 for the PWR case. Neutron thermalization varies considerably with radial distance from the axial centerline of the fuel zone, resulting in a complex situation for ruclear activation. This is illustrated in Figure 5.2. The corresponding situation for a BWR is shown in Figures 5.3 and 5.4. All calculations done in this work were for the case of core axial midplane. An approximate total inventory can be obtained by integrating this data over the axial neutron distribution as given by the ANISN calculation. In order to obtain a fast neutron spectrum the multigroup code DOT results of Gritzner et al. (1977) were used and renormalized such that the integral flux above 1 MeV agreed with that given by ANISN calculations shown in Figures 5.1 and 5.3 .

\subsection{RESULTS OF ACTIVATION CALCULATIONS}

An extensive series of activation calculations were carried out in the manner described above, using the average compositions of the appropriate materials, as reported in Section 4.2. In this discussion, all results are reported for core axial midplane, using volume averaged one-dimensional neutron 


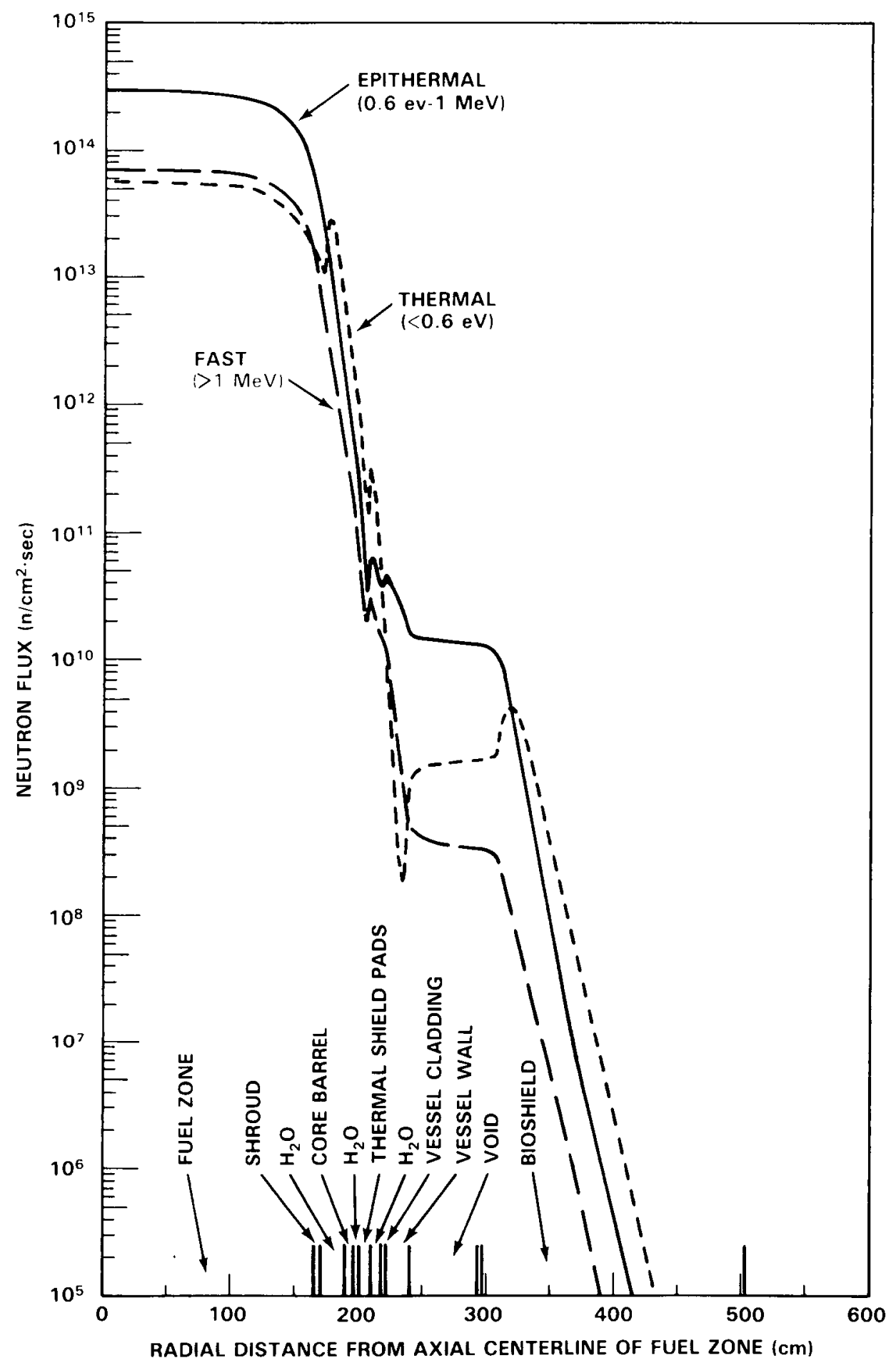

FIGURE 5.1. Radial Three Group Neutron Flux Distribution at Core Axial Midplane, ANISN Calculation for Westinghouse PWR 


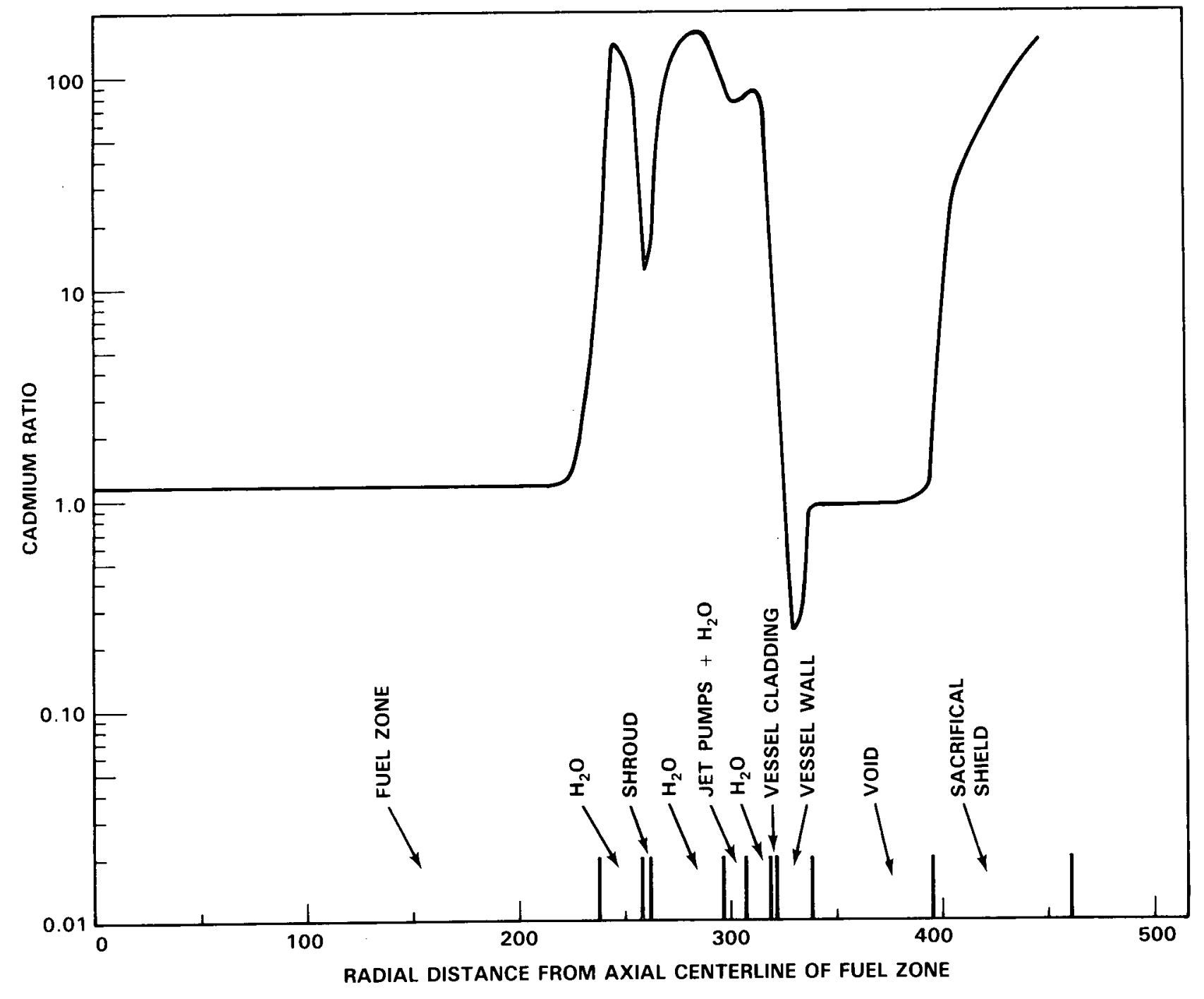

FIGURE 5.2. Cadmium Ratio Radial Distribution at Core Axial Midplane, ANISN Calculation for Westinghouse PWR 


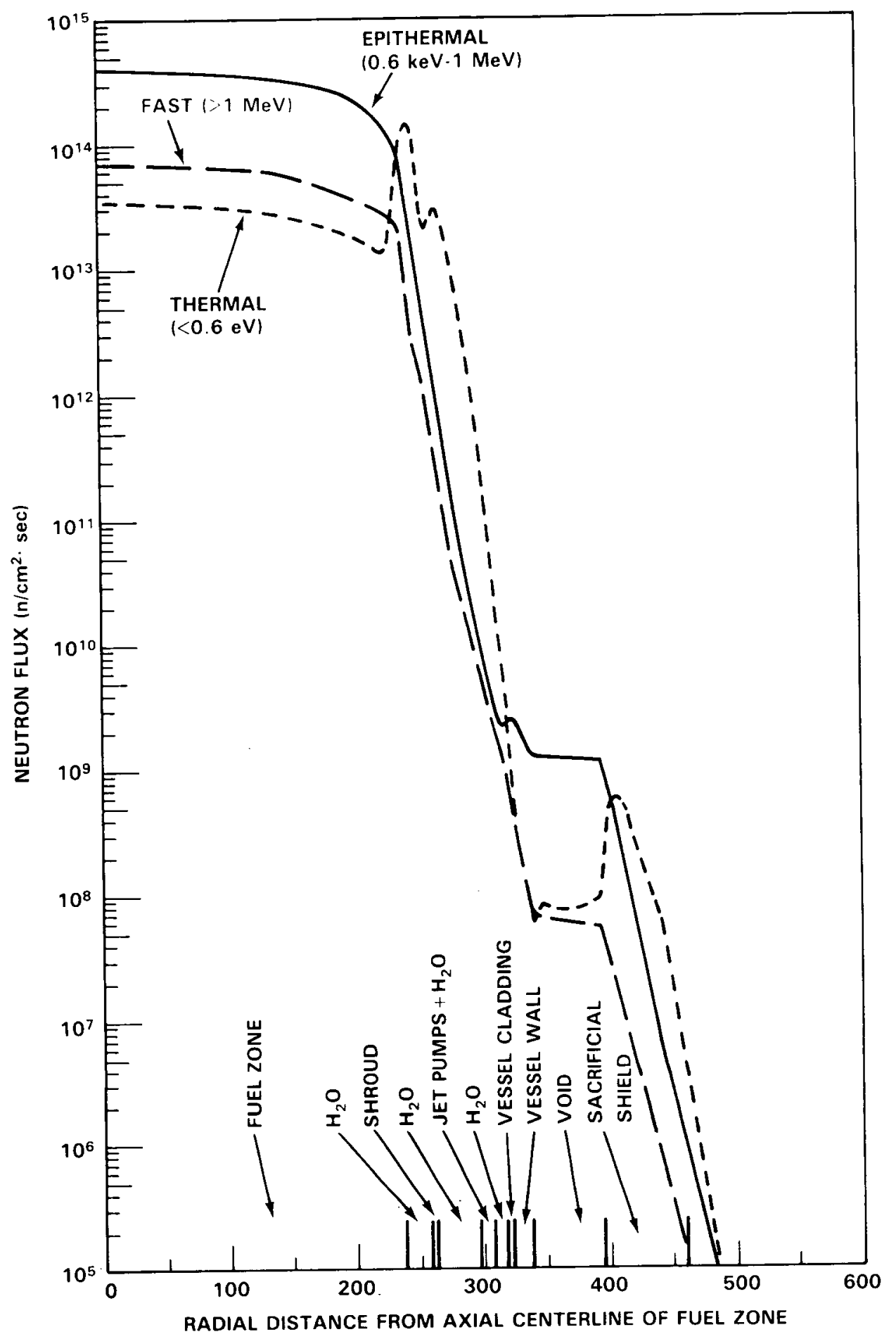

FIGURE 5.3. Radial Three Group Neutron Flux Distribution
at Core Axial Midplane, ANISN Calculation
GE BWR 


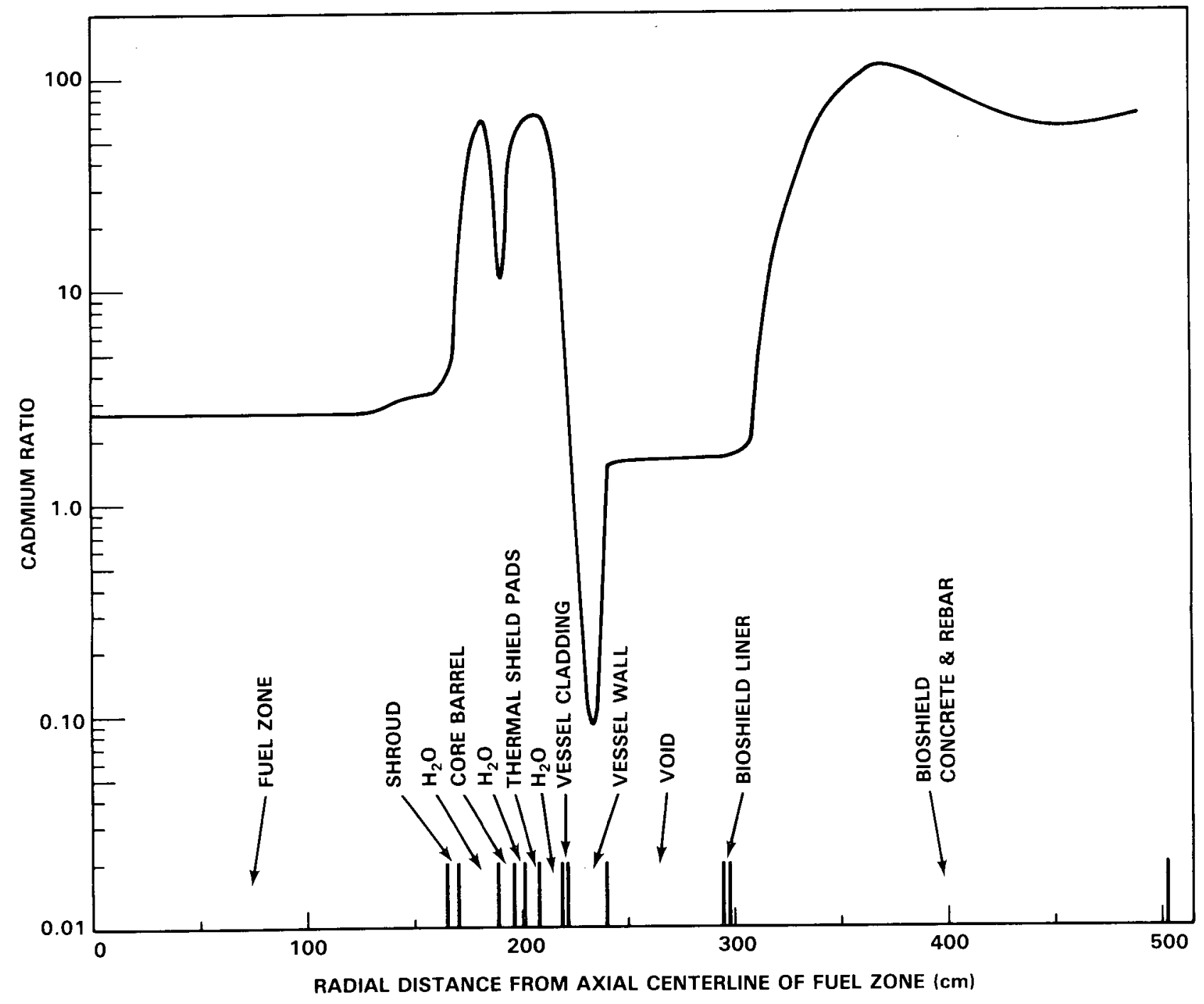

FIGURE 5.4. Cadmium Ratio Radial Distribution at Core Axial Midplane, ANISN Calculation for GE BWR 
transport data for the components of interest: Results are reported for the most massive reactor components, both internal and external, exclusive of the fuel itself. Two reference geometries were used, a Westinghouse PWR and a GE BWR.

\subsubsection{Internals}

Table 5.1 lists the calculated results for the 40 most significant activation products produced in a PWR shroud, core barrel, thermal pads and vessel cladding. This represents the specific activity of each isotope at the time of shutdown after a 40 year operating history at $75 \%$ duty factor. Most of the activity is located in the shroud, with a drop off in specific activity of about three orders of magnitude out to the vessel cladding. The ${ }^{60} \mathrm{Co}$ level in the shroud was calculated to be $0.13 \mathrm{Ci} / \mathrm{gm}$ based on an average cobalt concentration of $1414 \mathrm{ppm}$. Smith, Konzek, and Kennedy (1978) calculated $0.12 \mathrm{Ci} / \mathrm{gm}$ using an upper bound for the Co content of $1500 \mathrm{ppm}$. In this work it was found that the Co content of stainless steel can be up to twice that high affecting the ${ }^{60} C_{0}$ inventory correspondingly. Figure 5.5 shows the specific activity of the most abundant isotopes as a function of time on the decommissioning and dismantling time scale. The situation is heavily dominated by only a few isotopes. Cobalt-60 dominates the total activity from five years to about 20 years; however, it will dominate the gamma dose for 80 to 100 years. After about 100 years, ${ }^{94} \mathrm{Nb}$ becomes the dominant gamma emitter with a small contribution from ${ }^{59} \mathrm{Ni}$. The nickel isotopes tend to dominate the total activity after about only 20 years. Nickel-63 will be dominant for the first few hundred years, after which the steel contains mainly ${ }^{59} \mathrm{Ni}$ for several hundred thousand years. The latter case is illustrated in Figure 5.6 which can be considered a long-term disposal time scale. Figures 5.7, 5.8, and 5.9 illustrate basically the same situation for the core barrel, thermal pads, and vessel cladding, with decreasing levels of activity with increasing distance from the core. Minor differences in the patterns result from changes in neutron thermalization for different parts of the reactor. This results in a somewhat increased importance for ${ }^{14} \mathrm{C}$. Another interesting difference on Figures 5.8 and 5.9 is the appearance of minor amounts of 152 Eu in the outer portions of the reactor. This is caused by the diminishing importance of burnup of ${ }^{152}$ Eu as the neutron flux drops off. This still represents a trivial contribution, however, due to the very low abundance of europium in the stainless steel.

Table 5.2 gives the equivalent results for a BWR geometry. Due to the larger size of the core, specific activities are significantly lower in the BWR case, averaging about a factor of four lower in the shroud and a factor of thirteen lower for the vessel cladding. This is a bit deceptive, however, since the larger masses of the BWR components partially offsets the lower fluxes in the production of the total radionuclide inventory. 
TABLE 5.1. Activation of PWR Internals (Ci/gm) Type 304L Stainless Steel 30 EFPY at Core Axial Midplane

\begin{tabular}{|c|c|c|c|c|c|c|}
\hline Is & Half Life $(y)$ & Shroud & Core Barrel & Thermal & Pads & $\begin{array}{c}\text { Vessel } \\
\text { Cladding } \\
\end{array}$ \\
\hline${ }^{3} \mathrm{~T}$ & 12.3 & $1.0 \mathrm{E}-5$ & $9.6 \mathrm{E}-6$ & 2.2 & $E-6$ & 3. $3 \mathrm{E}-7$ \\
\hline${ }^{14} \mathrm{C}$ & 5730 & $2.5 E-5$ & 3.0 E-6 & 4.6 & $E-7$ & $5.6 E-8$ \\
\hline${ }^{36} \mathrm{Cl}$ & $3.0 E+5$ & $5.1 \mathrm{E}-7$ & $6.4 E-8$ & 1.0 & $E-8$ & $1.4 E-9$ \\
\hline${ }^{39} \mathrm{Ar}$ & 269 & $<1.5 \mathrm{E}-7$ & $<8 E-9$ & $<4.2$ & $E-10$ & $6 E-10$ \\
\hline${ }^{41} \mathrm{Ca}$ & $1.03 E+6$ & 4.7 E-9 & $5.6 E-10$ & 8.6 & $E-11$ & $1.2 \mathrm{E}-11$ \\
\hline${ }^{5} 3_{\mathrm{Mn}}$ & $3.7 E+6$ & $3.2 E-9$ & $2.1 \quad E-10$ & 1.0 & $\varepsilon-11$ & $6.9 E-12$ \\
\hline $54 \mathrm{Mn}$ & 0.85 & $6.5 E-3$ & $3.6 \mathrm{E}-4$ & 1.8 & $E-5$ & $1.2 E-5$ \\
\hline${ }^{55} \mathrm{Fe}$ & 2.7 & $2.1 \mathrm{E}-1$ & $2.4 E-2$ & 3.7 & $E-3$ & $5.4 E-4$ \\
\hline${ }^{59} \mathrm{Ni}$ & $8.0 E+4$. & $1.1 E-4$ & $1.9 E-5$ & 3.0 & $E-6$ & $4.3 E-7$ \\
\hline${ }^{60} \mathrm{Co}$ & 5.272 & $1.3 \mathrm{E}-1$ & $1.4 E-2$ & 2.0 & $E-3$ & $3.3 E-4$ \\
\hline $63_{\mathrm{Ni}}$ & 100 & $1.8 \mathrm{E}-2$ & $2.4 \mathrm{E}-3$ & 3.8 & $E-4$ & 5.4 E-5 \\
\hline${ }^{65} \mathrm{Zn}$ & 0.67 & $6.4 E-4$ & $4.5 E-5$ & 5.9 & $E-6$ & $9.9 E-7$ \\
\hline${ }^{79} \mathrm{Se}$ & $6.5 E+4$ & $6.1 E-10$ & 4. $6 \mathrm{E}-11$ & 4.7 & $E-12$ & 1.2 E-12 \\
\hline${ }^{81} \mathrm{Kr}$ & $2.1 E+5$ & $7.6 E-10$ & $3.4 E-12$ & 3.5 & $E-14$ & $2.1 E-15$ \\
\hline $85 \mathrm{kr}$ & 10.5 & $<8.5 \mathrm{E}-7$ & $1.9 \mathrm{E}-8$ & 9.5 & $E-10$ & $1.3 E-10$ \\
\hline${ }^{90} \mathrm{Sr}$ & 29 & $2 E-6$ & $<5 E-9$ & $<2.6$ & $E-9$ & $<3.6 E-10$ \\
\hline $92 m_{N b}$ & $2.7 E+7$ & $1.2 \mathrm{E}-12$ & $6.5 E-14$ & 3.2 & $E-15$ & $2.0 \mathrm{E}-15$ \\
\hline${ }^{93} \mathrm{Zr}$ & $9.5 E+5$ & $1.1 E-10$ & $3.9 E-12$ & 2.9 & $E-13$ & $8.6 E-14$ \\
\hline $9^{930}$ & 3500 & $9.4 \mathrm{E}-7$ & 3. $9 E-8$ & 2.1 & $E-9$ & $1.1 E-9$ \\
\hline${ }^{94} \mathrm{Nb}$ & $2.0 E+4$ & $4.0 \mathrm{E}-7$. & $2.9 E-8$ & 3.0 & $E-9$ & $7.5 E-10$ \\
\hline${ }^{99} \mathrm{TC}$ & $2.1 E+5$ & $1.3 \mathrm{E}-7$ & $8 . \grave{2} E-9$ & 4.2 & $E-10$ & $2.4 \mathrm{E}-10$ \\
\hline $108 m_{A g}$ & 130 & $<1 E=7$ & $<9 E-9$ & $<1.1$ & $E-9$ & $<2.2 E-10$ \\
\hline $121 m_{S n}$ & 50 & $4.8 E-9$ & 3.4 E-10 & 1.7 & $E-11$ & $1.1 E-11$ \\
\hline $129_{I}$ & $1.6 E+7$ & $<6 \quad E-13$ & $<1.4$ E-14 & $<7.9$ & $E-16$ & $<1.1 \mathrm{E}-16$ \\
\hline $133_{\mathrm{Ba}}$ & 10.4 & $<3 E-6$ & $<3 E-7$ & $<4.5$ & $E-8$ & $<7.1 E-9$ \\
\hline${ }^{134} \mathrm{Cs}$ & 2.06 & $<7 E-6$ & $<1 \quad E-6$ & $<1.7$ & $E-7$ & $<2.3 \mathrm{E}-8$ \\
\hline${ }^{135} \mathrm{cs}$ & $2.3 E+6$ & $<4 E-11$ & $<9 E-13$ & $<5.1$ & E-14 & $<7.8$ E-15 \\
\hline${ }^{137} \mathrm{Cs}$ & 30.1 & $<2 \mathrm{E}-6$ & $<5 E-8$ & $<2.7$ & $E-9$ & $<4.2$ E-10 \\
\hline${ }^{145} \mathrm{Pm}$ & 17.7 & $8.9 E-10$ & $1.4 \mathrm{E}-10$ & 2.2 & $E-11$ & $3.1 E-12$ \\
\hline${ }^{146} \mathrm{Sm}$ & $1.0 E+8$ & $1.0 E-16$ & $1.3 E-17$ & 6.7 & $E-19$ & $4.3 E-19$ \\
\hline${ }^{151} \mathrm{Sm}$ & 93 & 4.6 E-9 & $4.5 \mathrm{E}-9$ & 2.9 & $E-9$ & $5.9 \mathrm{E}-10$ \\
\hline${ }^{152} \mathrm{Eu}$ & 13 & 0 & $9.1 E-10$ & 1.7 & $E-7$ & $7.6 E-8$ \\
\hline${ }^{154} \mathrm{Eu}$ & 8.6 & $5.6 \mathrm{E}-7$ & $6.0 \mathrm{E}-7$ & 6.2 & $E-8$ & $1.2 \mathrm{E}-8$ \\
\hline${ }^{155} \mathrm{Eu}$ & 4.76 & $4.1 E-7$ & $1.4 \mathrm{E}-7$ & 5.0 & $E-9$ & $5.2 E-10$ \\
\hline${ }^{158} \mathrm{~Tb}$ & 150 & $1.9 \mathrm{E}-9$ & $1.7 \mathrm{E}-10$ & 8.5 & $\mathrm{E}-12$ & $5.6 \mathrm{E}-12$ \\
\hline $166 \mathrm{~m}_{\mathrm{Ho}}$ & 00 & $1.6 \mathrm{E}-7$ & $1.3 \mathrm{E}-8$ & 1.1 & $E-9$ & $3.0 E-10$ \\
\hline $178 m_{H f}$ & 30 & 4. $3 \mathrm{E}-8$ & $2.8 E-8$ & 3.1 & $E-9$ & $1.2 E-9$ \\
\hline${ }^{205} \mathrm{~Pb}$ & $1.4 \mathrm{E}+7$ & $1.8 E-12$ & $1.3 \mathrm{E}-13$ & 1.3 & $E-14$ & $3.4 E-15$ \\
\hline $233_{\mathrm{U}}$ & $1.6 \mathrm{E}+5$ & $<3.6$ E-10 & $<1.0 \mathrm{E}-10$ & 1.1 & $E-11$ & $3.4 \mathrm{E}-12$ \\
\hline${ }^{239} \mathrm{Pu}$ & $2.4 E+4$ & $<7.0$ E-9 & $<2.3 \mathrm{E}-9$ & 1.4 & $E-10$ & $9.6 E-11$ \\
\hline
\end{tabular}




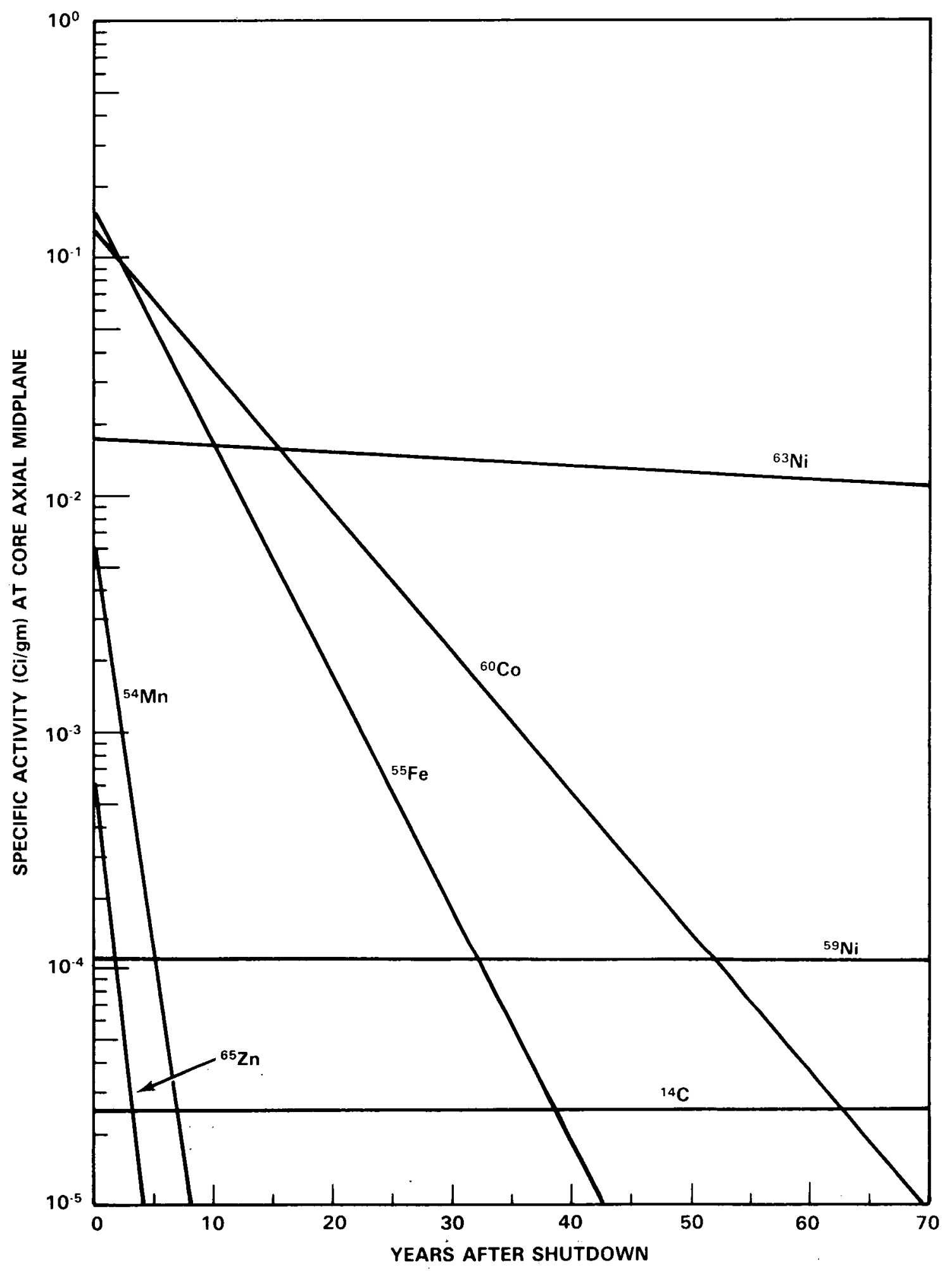

FIGURE 5.5. Activation of PWR Shroud Type 304 Stainless Steel 30 EFPY 


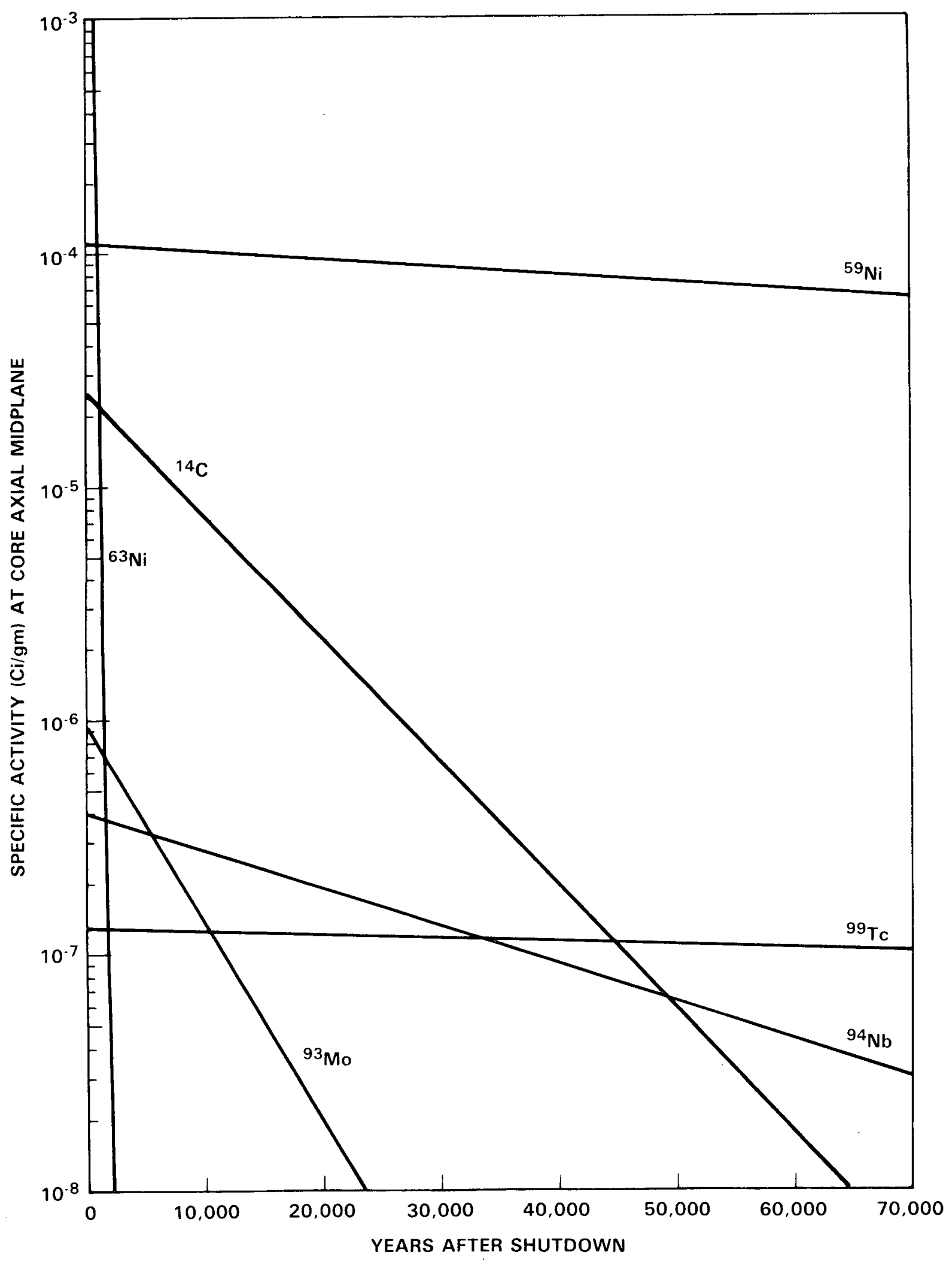

FIGURE 5.6. PWR Shroud Type 304 Stainless Steel 30 EFPY 


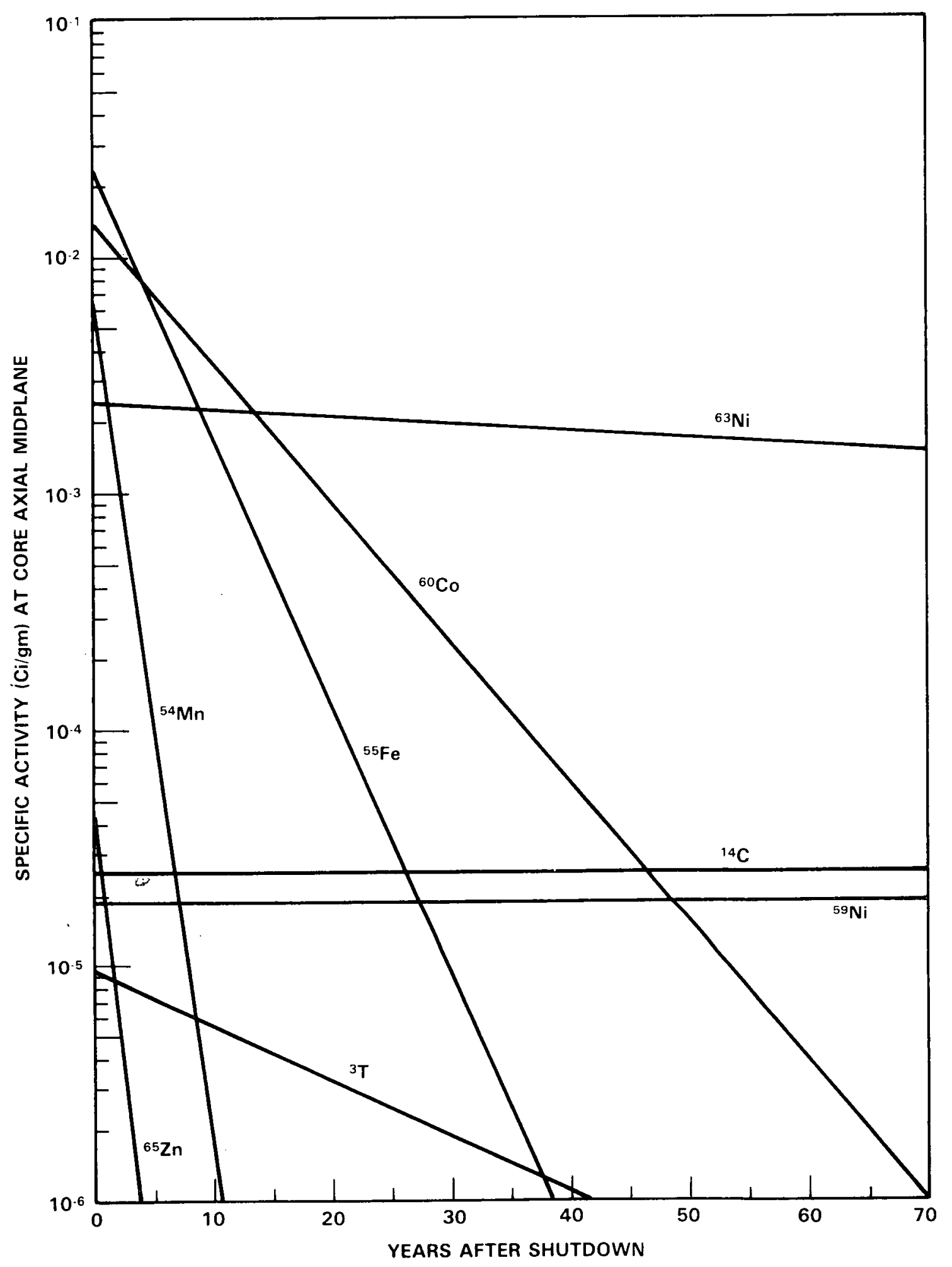

FIGURE 5.7. Activation of PWR Core Barrel Type 304 Stainless Steel 30 EFPY 


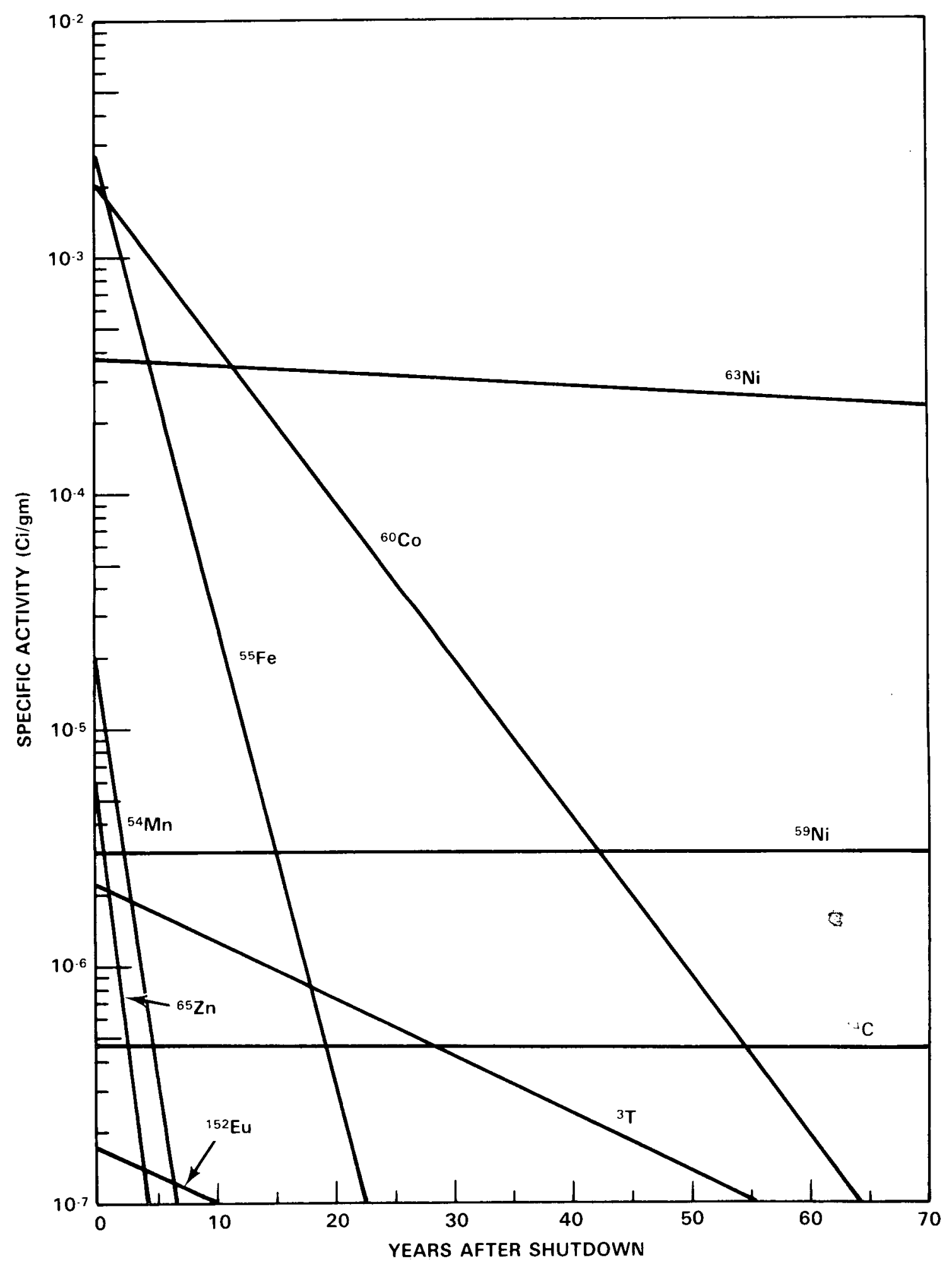

FIGURE 5.8. Activation of PWR Thermal Pads Type 304 Stainless
Steel 30 EFPY 


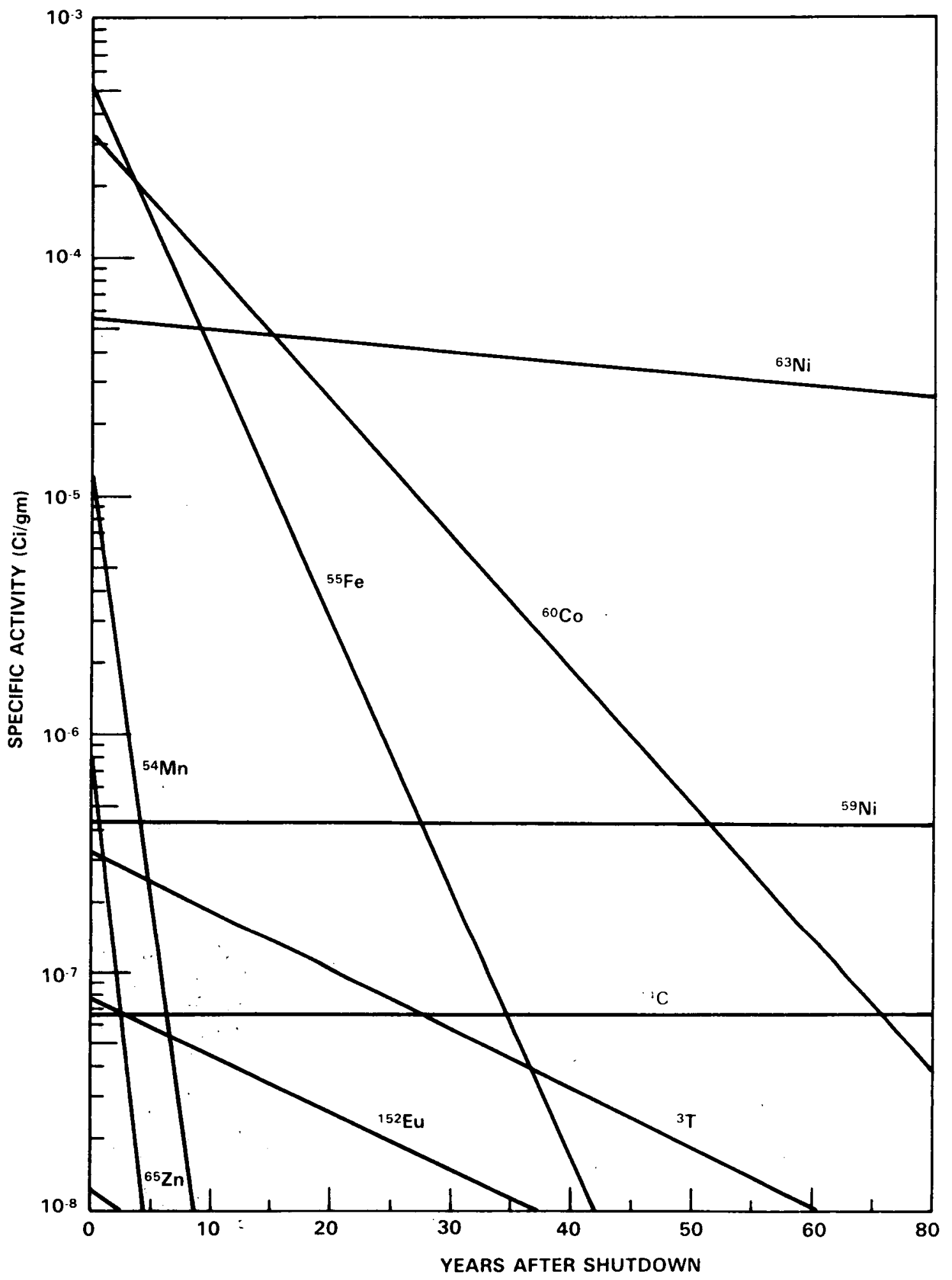

FIGURE 5.9. Activation of PWR Vessel Cladding Type 304 Stainless Steel 30 EFPY 
TABLE 5.2. Activation of BWR Internals (Ci/gm) Type 304L Stainless Steel 30 EFPY at Core Axial Midplane

\begin{tabular}{|c|c|c|c|}
\hline Isotope & Half-Life (Y) & Shroud & $\begin{array}{c}\text { Vessel } \\
\text { Cladding } \\
\end{array}$ \\
\hline${ }^{3} \mathrm{~T}$ & $1.20 E+01$ & $1.30 E-05$ & $2.50 E-08$ \\
\hline $14 \mathrm{C}$ & $5.70 E+03$ & $7.30 E-06$ & $4.90 \mathrm{E}-09$ \\
\hline $36 \mathrm{Cl}$ & $3.00 E+05$ & $1.60 \mathrm{E}-07$ & $0 \mathrm{E}-10$ \\
\hline${ }^{39} \mathrm{Ar}$ & $2.70 E+02$ & $1.90 \mathrm{E}-08$ & 5.30E-11 \\
\hline $41^{\prime \prime} \mathrm{Ca}$ & $1.00 \mathrm{E}+05$ & $1.40 E-09$ & $9.10 E-13$ \\
\hline $53 \mathrm{Mn}$ & $3.70 E+06$ & $4.60 E-10$ & $1.40 E-12$ \\
\hline & 8. $50 E-01$ & $8.30 E-04$ & $2.00 E-06$ \\
\hline 55 & $2.70 E+00$ & $5.90 E-02$ & $4.10 E-05$ \\
\hline $\mathrm{N}_{i}$ & $8.00 E+04$ & $4.30 E-05$ & $3.20 E-08$ \\
\hline${ }^{60} \mathrm{Co}$ & $5.30 E+00$ & $3.20 E-02$ & $2.40 E-05$ \\
\hline $63 \mathrm{Ni}$ & $1.00 E+02$ & $5.70 E-03$ & $4.00 E-06$ \\
\hline $65 \mathrm{Zn}$ & $6.70 \mathrm{E}-01$ & $1.10 \mathrm{E}-04$ & $7.10 E-08$ \\
\hline 79 & $6.50 E+04$ & $1.00 E-10$ & $1.70 E-13$ \\
\hline $81_{k}$ & $2.10 E+05$ & $<1.60 \mathrm{E}-11$ & $<9.40 E-18$ \\
\hline $85 \mathrm{Kr}$ & $1.10 E+01$ & $<5.80 E-08$ & $<9.00 E-12$ \\
\hline $90 \mathrm{Sr}$ & $2.90 E+01$ & $<1.50 \mathrm{E}-07$ & $<2.50 \mathrm{E}-11$ \\
\hline $92 m_{\mathrm{Nb}}$ & $2.70 E+07$ & $4.50 E-14$ & $3.80 E-16$ \\
\hline $93 \mathrm{Zr}$ & $9.50 E+05$ & $1.00 E-11$ & $1.20 E-14$ \\
\hline $93 \mathrm{Mo}$ & $3.50 E+00$ & $7.70 \mathrm{E}-08$ & $7.70 E-11$ \\
\hline $94 \mathrm{Nb}$ & $2.00 E+04$ & $6.31 E-08$ & $4.90 E-11$ \\
\hline${ }^{99} \mathrm{TC}$ & $2.10 E+05$ & $1.50 E-08$ & $1.50 E-11$ \\
\hline $108 \mathrm{~m} A g$ & $1.30 E+02$ & $<2.00 \mathrm{E}-08$ & $<1.50 \mathrm{E}-11$ \\
\hline $121 \mathrm{msn}_{\mathrm{s}}$ & $5.00 E+00$ & $7.60 \mathrm{E}-10$ & $2.00 E-12$ \\
\hline 129 & $1.60 \mathrm{E}+07$ & $<4.20 \mathrm{E}-14$ & $<7.60 \mathrm{E}-18$ \\
\hline 13 & 1. $00 \mathrm{E}+01$ & $<7.40 \mathrm{E}-07$ & $<6.00 E-10$ \\
\hline 13 & $2.10 E+00$ & $<2.40 \mathrm{E}-06$ & $<1.70 \mathrm{E}-09$ \\
\hline & $2.30 E+06$ & $<2.70 \mathrm{OE}-12$ & $<6.40 E-16$ \\
\hline & $3.00 E+01$ & $<1.50 \mathrm{E}-07$ & $<3.50 \mathrm{E}-11$ \\
\hline 14 & $1.80 E+01$ & $<3.10 \mathrm{E}-10$ & $<2.30 E-13$ \\
\hline & $1.00 E+08$ & $2.90 \mathrm{E}-17$ & $7.90 \mathrm{E}-20$ \\
\hline & $9.30 E+01$ & $3.80 E-09$ & $3.10 E-11$ \\
\hline & $1.30 E+01$ & $2.20 E-14$ & $6.70 E-09$ \\
\hline & $8.60 E+00$ & $9.10 E-07$ & $8.00 \mathrm{E}-10$ \\
\hline & $4.80 E+00$ & $3.60 \mathrm{E}-07$ & $2.90 E-11$ \\
\hline & $1.50 E+02$ & $3.80 E-10$ & $1.10 \mathrm{E}-12$ \\
\hline & $1.20 E+03$ & $2.80 \mathrm{E}-08$ & $1.90 \mathrm{E}-11$ \\
\hline $178 m_{H f}$ & $3.00 E+01$ & $<3.70 E-08$ & $<7.50 \mathrm{E}-11$ \\
\hline & $1.40 E-07$ & $2.90 \mathrm{E}-13$ & $4.50 E-16$ \\
\hline & $1.60 E+05$ & $<1.60 E-10$ & $<2.20 \mathrm{E}-13$ \\
\hline & $2.40 E+04$ & $<2.70 E-09$ & $<5.80 \mathrm{E}-1$ \\
\hline
\end{tabular}




\subsubsection{Pressure Vessel Wall}

Table 5.3 lists calculated activities in pressure vessel walls for both PWR and BWR geometries. The BWR case results in specific activities about a factor of 15 lower as previously discussed. The activation pattern is similar to stainless steel with, however, a diminished importance for the $\mathrm{Co}$ and $\mathrm{Ni}$ isotopes. One interesting consequence of this is that after about 80 years decay, ${ }^{152}$ Eu actually dominates the gamma activity. That would only be true for about 20 to 30 years at which point $94 \mathrm{Nb}$ becomes the dominant gamma emitting isotope with no further significant decay occurring on a historical time scale. This situation is demonstrated on Figures 5.10 and 5.11 . Figure 5.11 appears somewhat more complex than the equivalent case for stainless steel. This is somewhat of an artifact of the plotting method which is confined to four decades of relative importance. Dye to the lower abundance of $\mathrm{Ni}$ in carbon steel, other isotopes such as ${ }^{14} \mathrm{C}$ and ${ }^{36} \mathrm{Cl}$ become more noteworthy on the long time scale, however, the absolute levels are very low. In the case of ${ }^{14} \mathrm{C}$ in a PWR vessel wall. For example, calculated levels fall more than a factor of 500 below Class A disposal limits.

\subsubsection{Bioshield Concrete}

Activation levels of PWR bioshield concrete at the time of shutdown are given in Table 5.4 for several depths, in the bioshield. The maximum activation occurs between 10 and $20 \mathrm{~cm}$ from the inner surface for most isotopes due to neutron thermalization by the concrete. Activation levels for the decommissioning and disposal time scales respectively are shown on Figures 5.12 and 5.13. These plots are conspicuously more complex than the corresponding plots for steels. This is due to the much more complex mixture of major, minor, and trace elements found in the geological materials from which concrete is fabricated. On the 100 year time scale the total activity in concrete is dominated by tritium. On the long-term disposal scale, the total activity is completely dominated by ${ }^{4} \mathrm{Ca}$, comprising about $99 \%$ of the total. Gamma activity on the 100-year time scale is mainly due to ${ }^{152}$ Eu with ${ }^{6}$ Co being of relatively minor importance after the first 20 years. Europium-152 will in fact dominate the gamma activity for several hundred years after which time the material will be essentially nonradioactive with respect to gamma ray emission. The comparable data for a BWR are given in Table 5.5. Activation levels are reduced by about one order of magnitude due to the greater distance from the core center.

\subsubsection{Rebar}

Activation of rebar was considered independently in this study. Estimates of the relative proportion of rebar to concrete are difficult to obtain. An examination of the blueprints for the WNP No. 1 Reactor project, for example, showed an estimated weight percentage of rebar of about $10 \%$, however, this is very uncertain and varies considerably with location. Table 5.6 1ists the calculated results for PWR bioshield rebar. The time dependent levels are illustrated in Figures 5.14 and 5.15 . The pattern is similar to that of the vessel wall but at reduced levels. The comparable situation for a BWR is given in Table 5.7. As was the case with the concrete, activation levels are reduced about a factor of 10 relative to a PWR. 
TABLE 5.3. Activation of Pressure Vessel Walls (Ci/gm) 30 EFPY at Core Axial Midplane

\begin{tabular}{|c|c|c|c|}
\hline I sotope & Half-Life $(Y)$ & PWR & BWR \\
\hline${ }^{3} T$ & $1.20 E+01$ & $1.30 E-05$ & $2.50 E-08$ \\
\hline${ }^{14} \mathrm{C}$ & $5.70 E+03$ & $7.30 E-06$ & $4.90 E-09$ \\
\hline${ }^{36} \mathrm{Cl}$ & $3.00 E+05$ & $1.60 \mathrm{E}-07$ & $1.00 E-10$ \\
\hline $39 \mathrm{Ar}$ & $2.70 E+02$ & $1.90 \mathrm{E}-08$ & $5.30 E-11$ \\
\hline $41_{\mathrm{Ca}}^{\mathrm{m}}$ & 1. $00 E+05$ & $1.40 \mathrm{E}-09$ & $9.10 \mathrm{E}-13$ \\
\hline $53 \mathrm{Mn}$ & $3.70 E+06$ & $4.60 \mathrm{E}-10$ & 1. $40 E-12$ \\
\hline $54 M n$ & $8.50 \mathrm{E}-01$ & $8.30 E-04$ & $2.00 E-06$ \\
\hline $55_{\mathrm{Fe}}$ & $2.70 E+00$ & $5.90 E-02$ & 4.10E-05 \\
\hline $59_{\mathrm{Ni}}$ & 8.00E+04 & $4.30 \mathrm{E}-05$ & $3.20 E-08$ \\
\hline $60^{\circ} \mathrm{Co}$ & $5.30 E+00$ & $3.20 E-02$ & $2.40 E-05$ \\
\hline $63_{\mathrm{Ni}}$ & $1.00 \mathrm{E}+02$ & $5.70 E-03$ & $4.00 E-06$ \\
\hline $65 \mathrm{Zn}$ & $6.70 E-01$ & $1.10 \mathrm{O}-04$ & $7.10 E-08$ \\
\hline $79 \mathrm{Se}$ & $6.50 E+04$ & $1.00 E-10$ & $1.70 \mathrm{E}-13$ \\
\hline${ }^{81} \mathrm{Kr}$ & $2.10 E+05$ & $<1.60 \mathrm{E}-11$ & $<9.40 E-18$ \\
\hline $85_{\mathrm{Kr}}^{\mathrm{n}}$ & $1.10 \mathrm{E}+01$ & $<5.80 E-08$ & $<9.00 E-12$ \\
\hline $90 \mathrm{Sr}$ & $2.90 E+01$ & $<1.50 \mathrm{E}-07$ & $<2.50 E-11$ \\
\hline $92 m_{N b}$ & $2.70 E+07$ & $4.50 E-14$ & $3.80 \mathrm{E}-16$ \\
\hline $93 \mathrm{Zr}$ & $9.50 E+05$ & $1.00 E-11$ & $1.20 E-14$ \\
\hline $93 \mathrm{Mo}$ & $3.50 \mathrm{E}+00$ & $7.70 E-08$ & $7.70 \mathrm{E}-11$ \\
\hline $94 \mathrm{Nb}$ & 2. $00 E+04$ & $6.31 E-08$ & $4.90 E-11$ \\
\hline $99 \mathrm{~g}_{\mathrm{T}}$ & $10 F+05$ & $150 \mathrm{~F}-08$ & $1.50 \mathrm{~F}-11$ \\
\hline $108 \mathrm{~m}_{\mathrm{Ag}}$ & $30 E+02$ & $<2.00 E-08$ & $<1.50 \mathrm{E}-11$ \\
\hline $121 \mathrm{~m}_{\mathrm{Sn}}$ & 5.00E+00 & $<7.60 \mathrm{E}-18$ & 2.00E-12 \\
\hline${ }^{129} \mathrm{I}$ & $1.60 E+07$ & $<4.20 E-14$ & $<7.60 \mathrm{E}-18$ \\
\hline $133_{\mathrm{B}}^{2}$ & $1.00 E+01$ & $<7.40 \mathrm{E}-07$ & $<6.00 E-10$ \\
\hline $134 c s$ & $10 E+00$ & $<2.40 E-06$ & $<1.70 E-09$ \\
\hline $135 \mathrm{Cs}$ & $2.30 E+06$ & $<2.70 E-12$ & $<6.40 E-16$ \\
\hline $137 \mathrm{Cs}$ & 3. $00 E+01$ & $<1.50 E-07$ & $<3.50 \mathrm{E}-11$ \\
\hline $145 \mathrm{pm}$ & $1.80 E+01$ & $<3.1$ OE-10 & $<2.30 \mathrm{E}-13$ \\
\hline $146_{\mathrm{Sm}}^{\prime \prime}$ & $1.00 E+08$ & $2.90 E-17$ & $7.90 \mathrm{E}-20$ \\
\hline & $9.30 E+01$ & $3.80 E-09$ & $3.10 \mathrm{E}-11$ \\
\hline 152 & $1.30 E+01$ & $2.20 E-14$ & $6.70 E-09$ \\
\hline $154 \mathrm{Eu}$ & $8.60 E+00$ & $9.10 \mathrm{E}-07$ & $8.00 E-10$ \\
\hline 15 & 4. $80 E+00$ & $3.60 E-07$ & $2.90 E-11$ \\
\hline${ }^{158} \mathrm{~Tb}$ & $1.50 E+02$ & $3.80 E-10$ & $1.10 E-12$ \\
\hline $166 \mathrm{~m}_{\mathrm{Ho}}$ & $1.20 E+03$ & $2.80 E-08$ & $1.90 E-11$ \\
\hline $178 m_{\mathrm{Hf}}$ & $3.00 E+01$ & $<3.70 E-08$ & $<7.50 E-11$ \\
\hline $205 \mathrm{~Pb}$ & $1.40 E-07$ & $2.90 E-13$ & $4.50 E-16$ \\
\hline $233 U$ & $1.60 E+05$ & $<1.60 \mathrm{E}-10$ & $<2.20 E-13$ \\
\hline $239 \mathrm{pu}$ & $2.40 E+04$ & $<2.70 \mathrm{E}-09$ & $<5.80 E-12$ \\
\hline
\end{tabular}




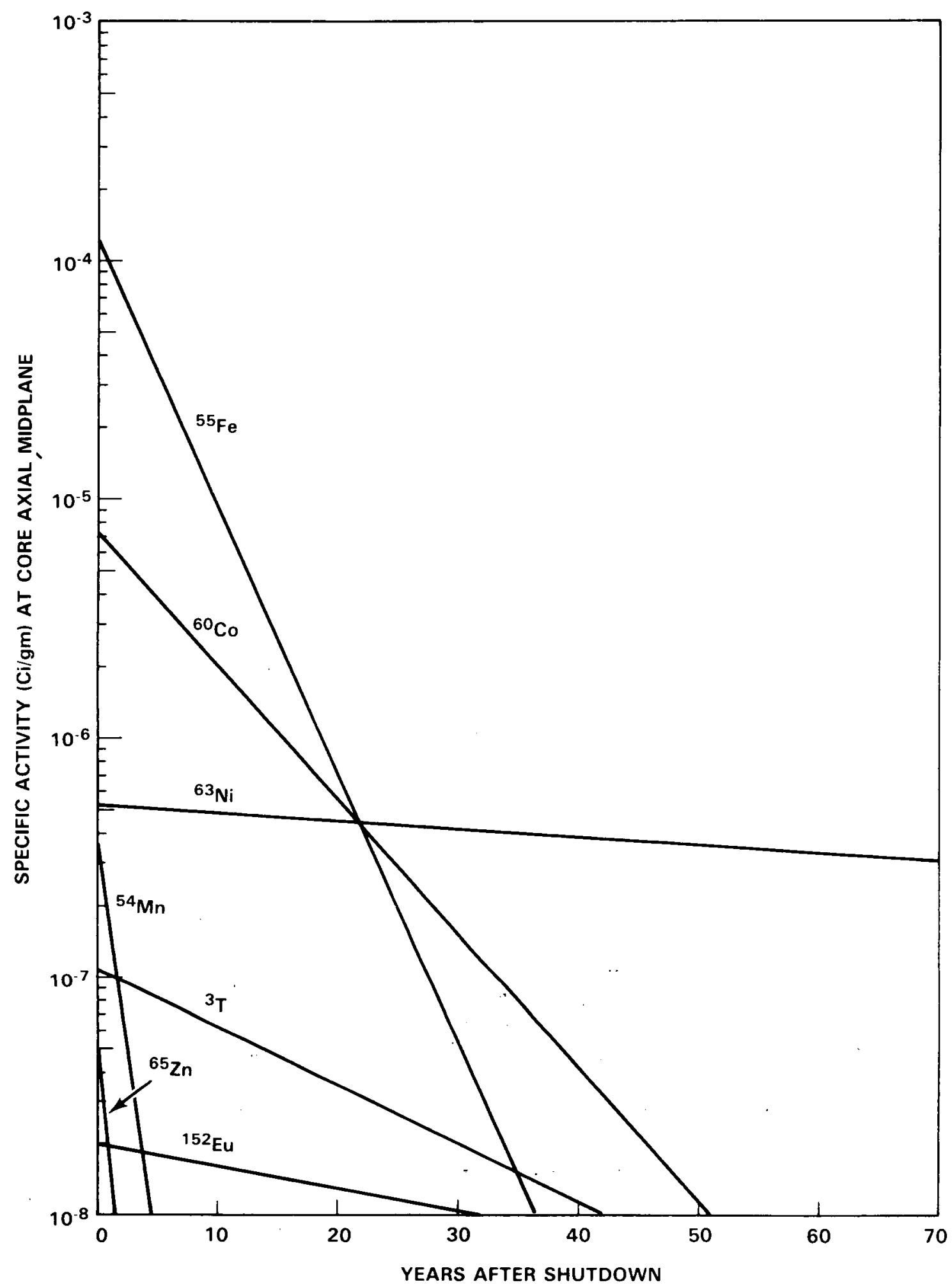

FIGURE 5.10. PWR Vessel Wall 30 EFPY - Decommissioning Time Scale 


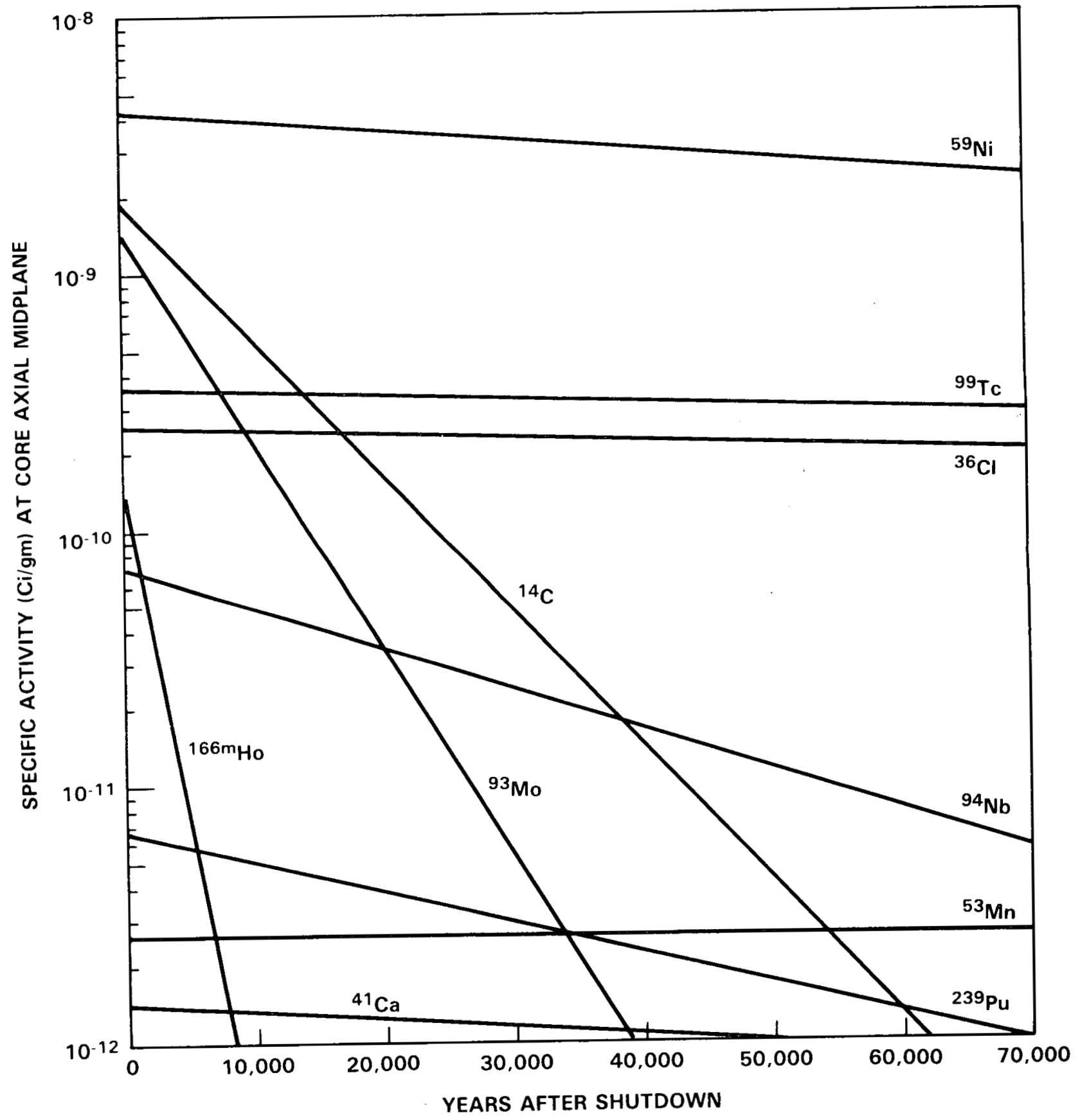

FIGURE 5.11. PWR Vessel Wall 30 EFPY - Long Term Disposal Time Scale 
TABLE 5.4. Activation of PWR Bioshield (Ci/gm) Average Concrete 30 EFPY at Core Axial Midplane

\begin{tabular}{|c|c|c|c|c|c|}
\hline Isotope & Half-Life $(Y)$ & Inner Edge & $10 \mathrm{~cm}$ & $24 \mathrm{~cm}$ & $55 \mathrm{~cm}$ \\
\hline$\overline{3_{T}}$ & $1.20 E+01$ & $5.00 E-06$ & $8.30 E-06$ & $4.40 E-06$ & $2.50 E-07$ \\
\hline $14 \mathrm{C}$ & $5.70 E+03$ & $1.70 E-09$ & $2.80 E-09$ & $1.50 \mathrm{E}-09$ & $8.30 E-11$ \\
\hline $36 \mathrm{Cl}$ & $3.00 E+05$ & $9.80 E-11$ & $1.50 \mathrm{E}-10$ & $7.90 \mathrm{E}-11$ & $4.40 E-12$ \\
\hline $39 \mathrm{Ar}$ & $2.70 E+02$ & $2.70 E-08$ & $1.20 \mathrm{E}-08$ & $3.10 E-09$ & $1.60 \mathrm{E}-10$ \\
\hline${ }^{41} \mathrm{Ca}$ & $1.00 E+05$ & $1.20 E-08$ & $1.90 E-08$ & 1.00E-08 & $5.60 \mathrm{E}-10$ \\
\hline $53 \mathrm{Mn}$ & $3.70 E+06$ & $1.70 E-14$ & $7.40 E-15$ & $1.90 E-15$ & $1.00 E-16$ \\
\hline $54 \mathrm{Mn}$ & $8.50 \mathrm{E}-01$ & $2.80 E-08$ & $1.20 \mathrm{E}-08$ & $3.10 \mathrm{E}-09$ & $1.70 E-10$ \\
\hline $55_{\mathrm{Fe}}$ & $2.70 E+06$ & $2.90 E-06$ & $4.70 E-06$ & $2.50 E-06$ & 1. $40 E-07$ \\
\hline $59 \mathrm{Ni}$ & $8.00 E+04$ & $1.60 E-11$ & $2.60 E-11$ & 1. $40 \mathrm{E}-11$ & $7.90 \mathrm{E}-13$ \\
\hline${ }^{60} \mathrm{Co}$ & $5.30 E+00$ & $2.20 E-07$ & $3.60 E-07$ & $1.70 E-07$ & $9.20 E-09$ \\
\hline $63 \mathrm{Ni}$ & $1.00 E+02$ & 2.00E-09 & $3.30 \mathrm{E}-09$ & $1.70 E-09$ & $9.80 \mathrm{E}-11$ \\
\hline $65 \mathrm{Zn}$ & $6.70 \mathrm{E}-01$ & $2.20 E-08$ & $2.50 E-09$ & $1.20 E-08$ & $6.40 E-10$ \\
\hline${ }^{79} \mathrm{Se}$ & $6.50 E+04$ & $2.30 E-15$ & $2.80 E-15$ & 1. $40 E-15$ & $7.90 \mathrm{E}-17$ \\
\hline $81 \mathrm{Kr}$ & $2.10 E+05$ & 1.10E-16 & $5.50 E-17$ & 7. $60 E-18$ & $1.70 E-20$ \\
\hline $85_{\mathrm{Kr}}^{\mathrm{kr}}$ & $1.10 E+01$ & $4.30 E-11$ & $4.20 \mathrm{E}-11$ & $1.70 E-11$ & $9.40 \mathrm{E}-13$ \\
\hline $90_{S r}^{n r}$ & 2.90E+01 & 4.50E-11 & 7. $30 \mathrm{E}-11$ & $3.80 E-11$ & $2.10 \mathrm{E}-12$ \\
\hline $92 m_{\mathrm{Nb}}$ & $2.70 E+07$ & $1.40 E-18$ & $1.20 E-19$ & $1.90 E-19$ & $1.00 E-20$ \\
\hline $93 z r$ & $9.50 E+05$ & 3. $00 \mathrm{E}-14$ & $2.90 E-14$ & 1. $30 E-14$ & $7.00 E-16$ \\
\hline $93_{\mathrm{Mo}}^{\mathrm{Li}}$ & $3.50 E+00$ & $1.20 E-12$ & $5.60 \mathrm{E}-13$ & $1.40 E-13$ & $4.40 E-15$ \\
\hline $94 \mathrm{Nb}$ & $2.00 E+04$ & $7.50 E-12$ & 5.30E-12 & 2.00E-12 & $9.40 E-14$ \\
\hline 99 & 2.10E+05 & $2.80 E-13$ & 1. $40 \mathrm{E}-13$ & $3.70 E-14$ & 1.30E-15 \\
\hline $108 \mathrm{mg}$ & $1.30 E+02$ & $<3.60 \mathrm{E}-12$ & $<3.20 E-12$ & $<1.40 E-12$ & $<7.30 E-14$ \\
\hline $121 \mathrm{~m}_{\mathrm{Sn}}$ & $5.00 E+00$ & $<6.50 E-13$ & $<5.20 E-13$ & $<1.80 E-13$ & $<1.20 E-14$ \\
\hline $129_{I}$ & $1.60 E+07$ & $1.40 \mathrm{E}-17$ & $2.20 E-17$ & $1.20 E-17$ & $6.60 E-19$ \\
\hline $133_{\mathrm{Ba}}^{2}$ & $1.00 E+01$ & $1.30 E-09$ & $2.00 E-09$ & $1.00 \mathrm{E}$ & $5.70 E-11$ \\
\hline $134 \mathrm{Cs}$ & $2.10 \mathrm{E}+00$ & $8.30 E-09$ & $1.60 E-08$ & $8.70 E-09$ & $4.90 E-10$ \\
\hline & $2.30 E+06$ & $9.50 E-16$ & $1.40 \mathrm{E}-15$ & $7.50 \mathrm{E}-16$ & $4.20 E-17$ \\
\hline $137_{\mathrm{Cs}}^{\mathrm{Cs}}$ & $3.00 E+01$ & $5.10 E-11$ & $7.60 E-11$ & $4.00 E$ & $2.20 E-12$ \\
\hline $145 \mathrm{Pm}$ & $1.80 E+01$ & $5.90 \mathrm{E}-12$ & $9.80 E-12$ & $5.20 \mathrm{E}-12$ & $2.90 E-13$ \\
\hline $146 \mathrm{Sm}$ & $1.00 E+08$ & $3.90 E-19$ & $1.70 E-19$ & 4. $40 E-20$ & $2.30 E-21$ \\
\hline $151_{\mathrm{Sm}}^{\mathrm{Jm}}$ & $9.30 E+01$ & $1.40 E-09$ & $1.40 E-09$ & $6.10 E-10$ & $3.10 E-11$ \\
\hline & $1.30 E+01$ & $2.40 E-07$ & $3.90 E-07$ & $2.10 E-07$ & $1.20 E-08$ \\
\hline $154 \mathrm{Eu}$ & $8.60 E+00$ & $5.60 E-08$ & $4.80 E-08$ & $2.00 E-08$ & $1.00 E-09$ \\
\hline $155_{\mathrm{Eu}}^{\mathrm{Lu}}$ & $4.80 E+00$ & $1.70 \mathrm{E}-09$ & $1.30 E-09$ & $5.00 E-10$ & $2.40 E-11$ \\
\hline & $1.50 \mathrm{E}+02$ & $2.20 \mathrm{E}-13$ & $9.60 E-14$ & $2.50 E-14$ & $1.30 \mathrm{E}-15$ \\
\hline & $1.20 E+03$ & $3.30 E-11$ & $3.90 E-11$ & $1.30 E-11$ & $5.60 E-13$ \\
\hline $178 m_{\mathrm{Hf}}$ & $3.00 E+01$ & $3.40 E-10$ & $1.80 E-10$ & $5.30 E-11$ & $2.10 E-12$ \\
\hline & $1.40 E+07$ & $2.80 E-16$ & $2.70 \mathrm{E}-17$ & $1.20 E-16$ & $6.60 \mathrm{E}-18$ \\
\hline & $1.60 E+05$ & $2.80 E-12$ & $1.20 E-11$ & $5.70 E-13$ & $2.50 E-14$ \\
\hline & $2.40 E+04$ & 4. $00 \mathrm{E}-11$ & $1.70 \mathrm{E}-11$ & $3.70 E-12$ & $9.30 E-14$ \\
\hline
\end{tabular}




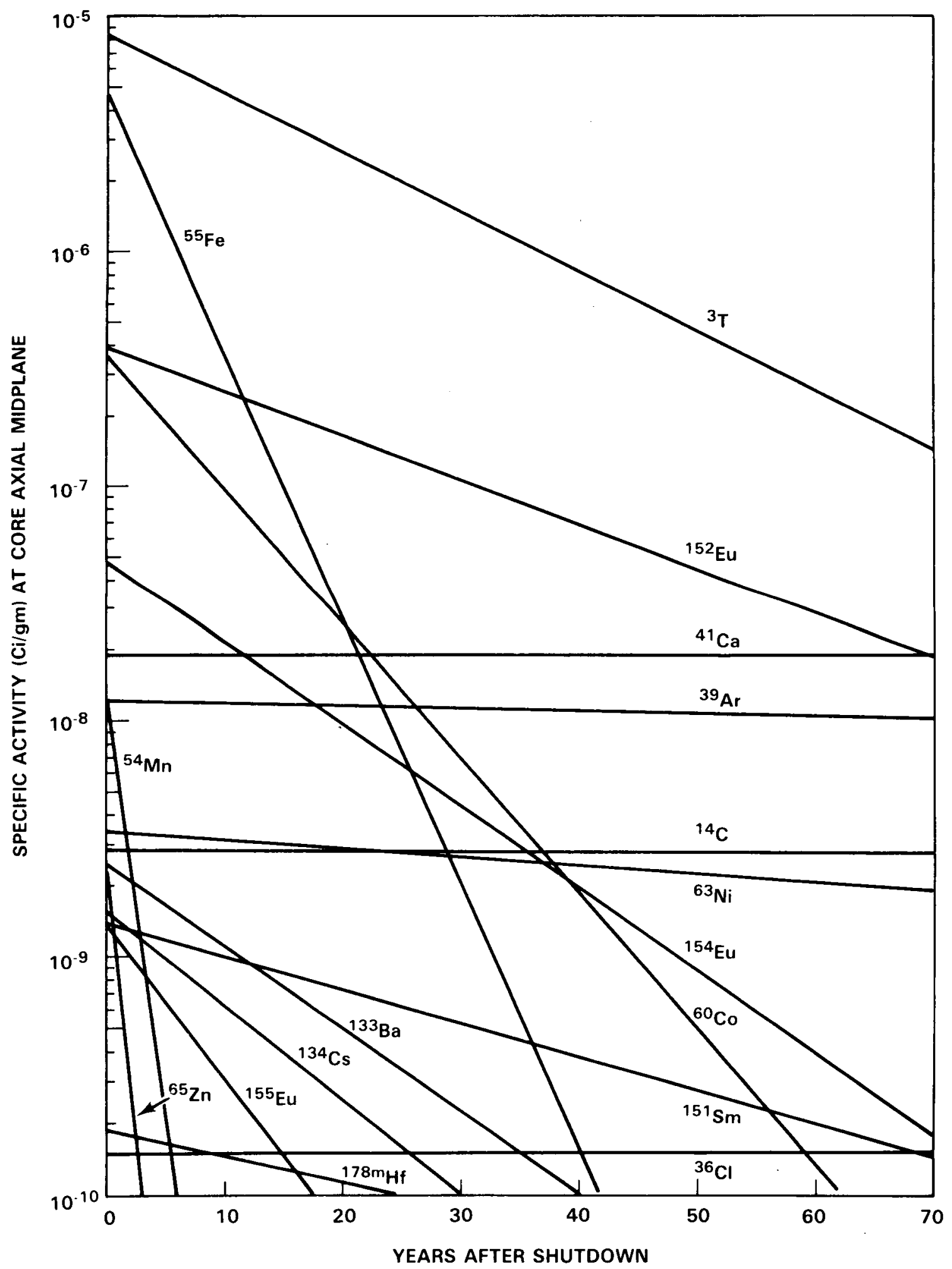

FIGURE 5.12. PWR Bioshield Average Concrete - $10 \mathrm{~cm}$ Depth 30 EFPY Decommissioning Time Scale 


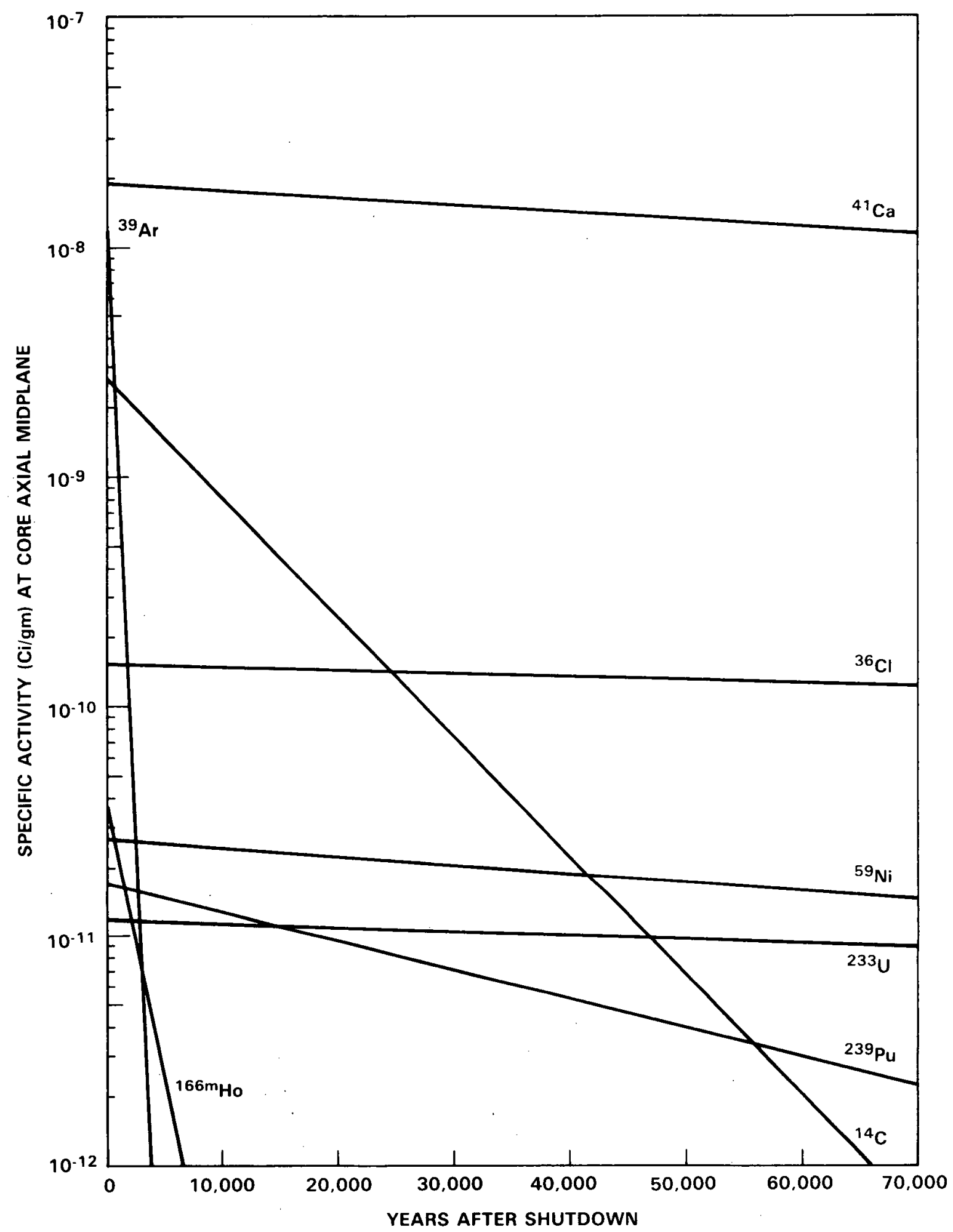

FIGURE 5.13. PWR Bioshield Average Concrete - $10 \mathrm{~cm}$ Depth 30 EFPY Long Term Disposal Time Scale 
TABLE 5.5. Activation of BWR Bioshield ( $\mathrm{Ci} / \mathrm{gm}$ ) Average Concrete 30 EFPY at Core Axial Midplane

\begin{tabular}{|c|c|c|c|c|c|c|}
\hline Isotope & Half-Life $(Y)$ & Inner tdge & $10 \mathrm{~cm}$ & $20 \mathrm{~cm}$ & $30 \mathrm{cIII}$ & $60 \mathrm{~cm}$ \\
\hline$\overline{3_{T}}$ & $1.20 E+01$ & $4.90 E-07$ & $8.60 E-07$ & $6.50 E-07$ & $3.40 E-07$ & $1.73 E-08$ \\
\hline${ }^{14} \mathrm{C}$ & $5.70 E+03$ & $1.70 t-10$ & 2. $90 \mathrm{E}-10$ & $2.20 \mathrm{E}-10$ & $1.10 E-10$ & $5.78 E-12$ \\
\hline${ }^{36} \mathrm{Cl}$ & $3.00 E+05$ & 1.10E-11 & $1.60 E-11$ & $1.20 \mathrm{E}-11$ & $6.00 \mathrm{E}-12$ & $3.15 E-13$ \\
\hline${ }^{39} \mathrm{Ar}$ & $2.70 E+02$ & $4.70 E-09$ & $1.90 E-09$ & $8.30 E-10$ & $3.20 \mathrm{E}-10$ & $2.65 \mathrm{t}-11$ \\
\hline${ }^{41} \mathrm{Ca}$ & $1.00 E+05$ & $1.10 \mathrm{E}-09$ & $2.00 E-09$ & $1.50 E-09$ & $7.60 E-10$ & $3.91 E-11$ \\
\hline $53 \mathrm{Mn}$ & $3.70 E+06$ & $3.80 E-15$ & $1.50 E-15$ & $6.70 \mathrm{E}-16$ & $2.50 E-16$ & $2.14 \mathrm{E}-17$ \\
\hline${ }^{54} \mathrm{Mn}$ & $8.50 E-01$ & 4. $90 E-09$ & $2.00 \mathrm{E}-09$ & $8.70 E-10$ & 3. $30 E-10$ & $2.76 E-11$ \\
\hline${ }^{55} \mathrm{Fe}$ & $2.70 E+00$ & 2.90E0-07 & 4. $90 \mathrm{E}-07$ & $3.60 \mathrm{E}-07$ & $1.90 E-07$ & $9.66 \mathrm{E}-09$ \\
\hline${ }^{59} \mathrm{Ni}$ & $8.00 E+04$ & $1.60 \mathrm{E}-12$ & $2.70 E-12$ & $2.00 \mathrm{E}-12$ & $1.10 E-12$ & $5.47 E-14$ \\
\hline${ }^{60} \mathrm{Co}$ & $5.30 E+00$ & $2.80 E-08$ & $3.50 E-08$ & $2.50 \mathrm{E}-08$ & $1.30 E-08$ & $6.41 \mathrm{E}-10$ \\
\hline${ }^{63} \mathrm{Ni}$ & $1.00 E+02$ & $2.00 E-10$ & $3.40 E-10$ & $2.50 E-10$ & 1. $30 \mathrm{E}-10$ & $6.81 \mathrm{E}-1$ \\
\hline $65 \mathrm{Zn}$ & $6.70 E-01$ & $2.00 E-09$ & $2.50 E-09$ & $1.70 E-09$ & $8.70 E-10$ & $4.49 E-11$ \\
\hline${ }^{79} \mathrm{Se}$ & $6.50 E+04$ & $3.20 \mathrm{E}-16$ & $3.30 E-16$ & $2.20 E-16$ & $1.10 \mathrm{E}-16$ & $6.16 \mathrm{E}-18$ \\
\hline $81_{\mathrm{Kr}}$ & $2.10 E+05$ & $7.20 E-19$ & $4.50 E-19$ & $1.60 E-19$ & $3.40 E-20$ & $8.69 E-23$ \\
\hline $85_{\mathrm{Kr}}$ & $1.10 E+01$ & $6.30 E-12$ & $4.60 E-12$ & $2.90 \mathrm{E}-12$ & $1.40 \mathrm{E}-12$ & $8.06 \mathrm{E}-10$ \\
\hline${ }^{90} \mathrm{Sr}$ & $2.90 E+01$ & 4. $30 \mathrm{E}-12$ & $7.40 E-12$ & $5.60 \mathrm{E}-12$ & $2.90 E-12$ & $1.49 \mathrm{E}-13$ \\
\hline $92 m_{N b}$ & $2.70 E+07$ & $3.70 E-19$ & $2.10 E-19$ & $6.50 E-20$ & $2.40 E-20$ & $2.10 \mathrm{E}-21$ \\
\hline $93 \mathrm{Zr}$ & $9.50 E+05$ & $2.90 \mathrm{E}-15$ & 2. $90 E-15$ & $2.00 E-15$ & $9.70 E-16$ & $5.07 \mathrm{E}-17$ \\
\hline${ }^{93} 3_{\text {Mo }}$ & $3.50 E+00$ & $9.40 \mathrm{E}-14$ & $4.50 E-14$ & $2.00 E-14$ & $7.20 E-15$ & $3.56 \mathrm{E}-16$ \\
\hline${ }^{94} \mathrm{Nb}$ & $2.00 E+04$ & $6.10 \mathrm{E}-13$ & $4.70 E-13$ & $2.90 \mathrm{E}-13$ & $1.30 E-13$ & $6.72 E-15$ \\
\hline${ }^{99} \mathrm{Tc}$ & $2.10 E+05$ & 2. $20 E-14$ & $1.10 E-14$ & $5.20 E-15$ & $2.00 E-15$ & $9.90 \mathrm{E}-17$ \\
\hline $108 m_{A g}$ & 1. $30 \mathrm{E}+02$ & $<3.10 E-13$ & $<3.10 E-13$ & $<2.10 \mathrm{E}-13$ & $<1.00 \mathrm{E}-13$ & $<5.13 \mathrm{E}-15$ \\
\hline $121 m_{S n}$ & $5.00 E+00$ & $<1.20 \mathrm{E}-13$ & $<7.40 E-14$ & $<4.30 \mathrm{E}-14$ & $<2.00 \mathrm{E}-14$ & $<1.23 E-15$ \\
\hline $129 l$ & $1.60 E+07$ & 1. $30 \mathrm{E}-18$ & $2.30 E-18$ & $1.70 E-18$ & $8.90 E-19$ & $4.58 E-2 C$ \\
\hline${ }^{133} \mathrm{Ba}$ & $1.00 \mathrm{E}+01$ & 1. $30 \mathrm{E}-10$ & $2.10 E-10$ & $1.50 \mathrm{E}-10$ & $7.80 E-11$ & $4.03 \mathrm{E}-12$ \\
\hline${ }^{134} \mathrm{Cs}$ & 2. $10 E+00$ & $8.50 E-10$ & $1.70 E-09$ & 1. $30 \mathrm{E}-09$ & $6.60 E-10$ & $3.41 E 11$ \\
\hline${ }^{135} \mathrm{Cs}$ & 2. $30 E+06$ & $9.90 \mathrm{E}-17$ & $1.50 E-16$ & $1.10 E-16$ & $5.70 E-17$ & $2.97 \mathrm{E}-18$ \\
\hline${ }^{137} \mathrm{Cs}$ & $3.00 E+01$ & $5.30 E-12$ & $8.00 E-12$ & $5.90 E-12$ & $3.00 E-12$ & $1.58 \mathrm{E}-13$ \\
\hline${ }^{145} \mathrm{Pm}$ & $1.80 E+01$ & $5.80 E-13$ & $1.00 E-12$ & $7.60 \mathrm{E}-13$ & $4.00 E-13$ & $2.04 E-14$ \\
\hline${ }^{146} \mathrm{Sm}$ & $1.00 E+08$ & $8.20 E-20$ & $3.30 E-20$ & $1.50 E-20$ & $5.50 \mathrm{E}-21$ & $4.61 E-22$ \\
\hline${ }^{151_{S m}}$ & $9.30 E+01$ & $1.20 E-10$ & 1. $30 E-10$ & $8.50 E-11$ & $4.20 E-11$ & $2.14 \mathrm{E}-12$ \\
\hline $152 \subseteq u$ & 1. $30 \mathrm{E}+01$ & $2.40 E-08$ & $4.20 E-08$ & $3.20 E-08$ & $1.60 \mathrm{E}-08$ & $8.44 E-10$ \\
\hline${ }^{154} \mathrm{Eu}$ & $8.60 E+00$ & $4.70 \mathrm{E}-09$ & $4.50 E-09$ & $3.00 E-09$ & 1. $40 \mathrm{E}-09$ & 7. $35 \mathrm{E}-11$ \\
\hline${ }^{155_{E u}}$ & $4.80 E+00$ & $1.40 \mathrm{E}-10$ & $1.20 E-10$ & $7.10 \mathrm{E}-11$ & 3. $30 E-11$ & $1.69 \mathrm{E}-12$ \\
\hline${ }^{158} \mathrm{~Tb}$ & $1.50 E+02$ & $4.80 \mathrm{E}-14$ & $2.00 E-14$ & $8.60 E-15$ & $3.20 \mathrm{E}-15$ & $2.71 E-16$ \\
\hline $166 \mathrm{~m}_{\mathrm{Ho}}$ & $1.20 E+03$ & $5.10 E-12$ & 3. $30 \mathrm{E}-12$ & $1.80 E-12$ & $8.10 E-13$ & $4.09 \mathrm{E}-14$ \\
\hline $178 m_{H f}$ & $3.00 E+01$ & $2.70 \mathrm{E}-11$ & $1.50 \mathrm{E}-11$ & $7.60 E-12$ & 3. 1UE-12 & $1.56 E-13$ \\
\hline $205 \mathrm{~Pb}$ & $1.40 E+07$ & $3.40 E-17$ & $3.00 \mathrm{E}-17$ & $2.00 E-17$ & $9.50 E-18$ & $5.20 E-19$ \\
\hline $233 U$ & $1.60 E+05$ & 2. $20 \mathrm{E}-13$ & $1.50 \mathrm{E}-13$ & $8.10 E-14$ & $3.60 \mathrm{E}-14$ & $1.80 E-15$ \\
\hline${ }^{239} \mathrm{Pu}$ & $2.40 E+04$ & 3. $10 \mathrm{E}-12$ & 1. $30 \mathrm{E}-12$ & $5.20 \mathrm{E}-13$ & $1.60 \mathrm{E}-13$ & $7.81 E-15$ \\
\hline
\end{tabular}


TABLE 5.6. Activation of PWR Bioshield ( $\mathrm{Ci} / \mathrm{gm}$ ) Average Rebar 30 EFPY at Core Axial Midplane

\begin{tabular}{|c|c|c|c|c|c|}
\hline Isotope & Half-Life $(Y)$ & Inner Edge & $10 \mathrm{~cm}$ & $24 \mathrm{~cm}$ & $55 \mathrm{~cm}$ \\
\hline 3 & $1.20 E+01$ & $2.50 E-08$ & $4.10 E-08$ & $2.20 E-08$ & 1. $30 \mathrm{E}-09$ \\
\hline $14 \mathrm{C}$ & $5.70 E+03$ & $1.10 E-09$ & $1.80 E-09$ & $9.50 E-10$ & $5.40 E-11$ \\
\hline $36 \mathrm{Cl}$ & $3.00 E+05$ & $6.70 E-14$ & $2.90 E-14$ & $7.60 E-15$ & 4. $00 E-16$ \\
\hline${ }^{39} \mathrm{Ar}$ & $2.70 E+02$ & $1.40 E-10$ & $6.20 E-11$ & $1.60 E-11$ & $8.70 E-13$ \\
\hline${ }^{41} \mathrm{Ca}$ & $1.00 E+05$ & $3.20 E-12$ & $5.20 E-12$ & $2.70 E-12$ & $1.50 E-13$ \\
\hline $53 M n$ & $3.70 E+06$ & 4. $30 E-13$ & $1.90 E-13$ & $4.90 E-14$ & $2.50 E-15$ \\
\hline $54 \mathrm{Mn}$ & $8.50 E-01$ & $7.00 E-07$ & $3.00 E-07$ & $7.90 E-08$ & $4.20 E-09$ \\
\hline $55^{\prime \prime m e}$ & $2.70 E+00$ & 7. $30 E-05$ & $1.20 E-04$ & $6.20 E-05$ & $3.50 E-06$ \\
\hline $59 \mathrm{Ni}$ & $8.00 E+04$ & $4.50 E-10$ & $7.40 \mathrm{E}-10$ & $4.00 E-10$ & $2.20 E-11$ \\
\hline $60 \mathrm{Co}$ & $5.30 E+00$ & $3.40 E-06$ & $3.70 E-06$ & $1.80 E-06$ & $9.60 E-08$ \\
\hline $63 \mathrm{Ni}$ & $1.00 E+02$ & $5.50 E-08$ & $9.30 E-08$ & $4.90 E-08$ & $2.80 E-09$ \\
\hline $65 \mathrm{Zn}$ & $6.70 E-01$ & $2.00 E-08$ & $2.20 E-08$ & $1.10 E-08$ & $5.70 E-10$ \\
\hline${ }_{01}^{79} \mathrm{Se}$ & $6.50 E+04$ & $4.60 E-15$ & $5.50 E-15$ & $2.80 E-15$ & $1.60 E-16$ \\
\hline $81 k r$ & $2.10 E+05$ & $<4.50 E-17$ & $<2.30 E-17$ & $<3.20 E-18$ & $<7.00 E-21$ \\
\hline $85 \mathrm{kr}$ & 1. $10 E+01$ & $<2.10 E-11$ & $<1.50 E-11$ & $<6.30 E-12$ & $<3.50 E-13$ \\
\hline $90 \mathrm{Sr}$ & $2.90 E+01$ & $<1.50 E-11$ & $<2.40 E-11$ & $<1.30 E-11$ & $<7.10 \mathrm{E}-13$ \\
\hline $92 \tilde{m}_{\mathrm{Nb}}$ & $2.70 E+07$ & $<1.90 \mathrm{E}-17$ & $<5.80 E-18$ & $<1.50 E-18$ & $<7.90 E-20$ \\
\hline $93 \mathrm{Zr}$ & $9.50 E+05$ & $4.50 \mathrm{E}-15$ & $4.80 E-15$ & $2.10 E-15$ & 1. $10 E-16$ \\
\hline $93 \mathrm{MO}$ & $3.50 E+03$ & $2.50 E-11$ & $1.20 E-11$ & $2.90 E-12$ & $9.60 E-14$ \\
\hline${ }^{94} \mathrm{Nb}$ & $2.00 E+04$ & $<7.00 E-11$ & $<4.90 E-11$ & $<1.80 \mathrm{E}-11$ & $<8.70 E-13$ \\
\hline $99 \mathrm{Tc}$ & $2.10 E+05$ & $5.70 E-12$ & $2.60 E-12$ & $6.10 E-13$ & $1.80 E-14$ \\
\hline $108 m_{\mathrm{Ag}}$ & $1.30 E+02$ & $7.60 E-11$ & $6.80 E-11$ & $3.00 E-11$ & $1.50 E-12$ \\
\hline $121 \mathrm{~m}_{\mathrm{Sn}}$ & $5.00 E+00$ & $2.00 E-12$ & $8.40 E-13$ & $2.20 E-13$ & $1.20 E-14$ \\
\hline 129 & $1.60 E+07$ & $<4.60 E-18$ & $<8.00 E-18$ & $<3.90 E-18$ & $<2.20 E-19$ \\
\hline $133 \mathrm{Ba}$ & $1.00 E+01$ & $<5.40 \mathrm{E}-10$ & $<8.20 E-10$ & $<4.30 E-10$ & $<2.40 E-11$ \\
\hline${ }^{134} \mathrm{Cs}$ & $2.10 E+00$ & $<3.80 E-09$ & $<7.30 E-09$ & $<4.00 E-09$ & $<2.30 E-10$ \\
\hline 135 & $2.30 E+06$ & $<3.20 E-16$ & $<4.80 E-16$ & $<2.50 E-16$ & $<1.40 \mathrm{E}-1\rangle$ \\
\hline 137 & 3. $00 E+01$ & $<1.70 \mathrm{E}-11$ & $<2.60 E-11$ & $<1.30 E-11$ & $<7.40 \mathrm{E}-13$ \\
\hline & $1.80 E+01$ & $<1.20 E-13$ & $<2.00 E-13$ & $<1.10 E-13$ & $<5.90 E-15$ \\
\hline & $1.00 E+08$ & $<7.20 E-21$ & $<3.40 E-21$ & $<8.80 E-22$ & $<4.60 \mathrm{E}-23$ \\
\hline & $9.30 E+01$ & $<2.80 E-11$ & $<2.90 E-11$ & $<1.30 E-11$ & $<6.30 \mathrm{E}-13$ \\
\hline & $1.30 E+01$ & $<3.90 E-08$ & $<6.40 \mathrm{E}-08$ & $<3.50 E-08$ & $<2.00 E-09$ \\
\hline & $8.60 E+00$ & $9.10 E-09$ & $<7.80 E-09$ & $<3.30 E-09$ & $<1.70 \mathrm{E}-10$ \\
\hline & $4.80 E+00$ & $<4.10 E-11$ & $<3.60 \mathrm{E}-11$ & $<1.20 E-11$ & $<4.90 E-13$ \\
\hline & $1.50 E+02$ & $<5.40 E-13$ & $<2.30 E-13$ & $<6.10 \mathrm{E}-14$ & $<3.20 E-15$ \\
\hline & $1.20 E+03$ & $<2.80 E-11$ & $<1.70 \mathrm{E}-11$ & $<5.70 E-12$ & $<2.50 E-13$ \\
\hline & $3.00 E+01$ & $<1.20 E-10$ & $<6.70 E-11$ & $<1.90 \mathrm{E}-11$ & $<7.60 E-13$ \\
\hline & 1. $40 E+07$ & $<4.20 E-16$ & $<4.00 E-16$ & $<1.80 E-16$ & $<9.80 E-18$ \\
\hline & $1.60 E+05$ & $<4.80 E-13$ & $<2.90 E-13$ & $<9.70 E-14$ & $<4.30 E-15$ \\
\hline & $2.40 E+04$ & $<1.30 E-11$ & $<5.80 E-12$ & $<1.20 E-12$ & $<3.10 E-14$ \\
\hline
\end{tabular}




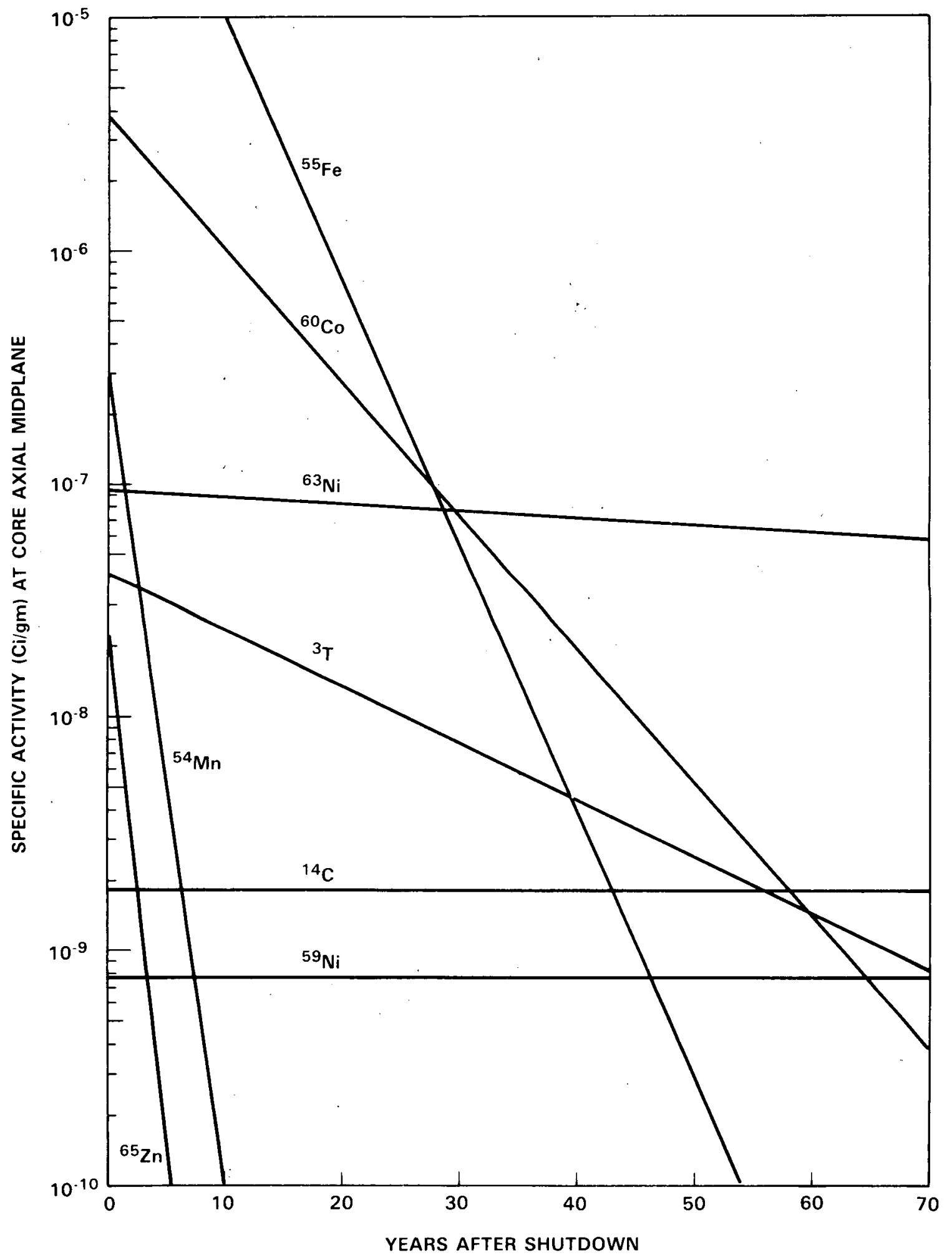

FIGURE 5.14. PWR Bioshield Rebar - $10 \mathrm{~cm}$ Depth 30 EFPY Decommissioning Time Scale 


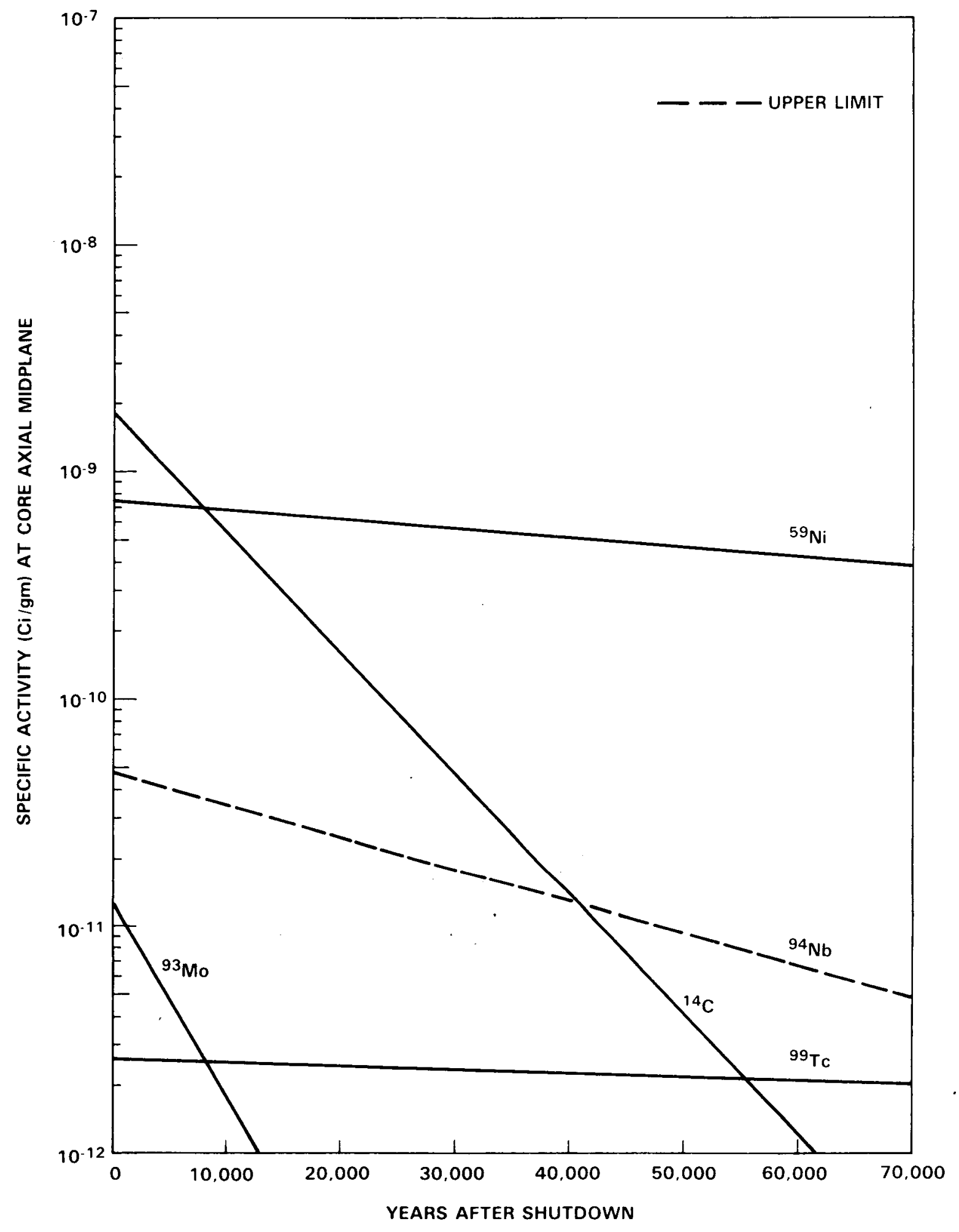

FIGURE 5.15. PWR Bioshield Rebar - $10 \mathrm{~cm}$ Depth 30 EFPY Low Term Disposal Time Scale 
TABLE 5.7. Activation of BWR Bioshield (Ci/gm) Average Rebar 30 EFPY at Core Axial Midplane

\begin{tabular}{|c|c|c|c|c|c|c|}
\hline Isotope & Half-Life $(Y)$ & Inner Edye & $10 \mathrm{~cm}$ & $20 \mathrm{cIn}$ & $30 \mathrm{~cm}$ & $60 \mathrm{~cm}$ \\
\hline${ }^{3} \mathrm{~T}$ & $1.20 E+01$ & $2.46 E-09$ & $4.31 E-09$ & $3.23 E-09$ & $1.68 E-09$ & $8.60 E-11$ \\
\hline${ }_{2 c}^{14} \mathrm{C}$ & $5.70 E+03$ & $1.06 \mathrm{E}-10$ & $1.85 \mathrm{E}-10$ & $1.39 \mathrm{E}-10$ & $7.21 \mathrm{E}-11$ & 3.70E-12 \\
\hline${ }^{36} \mathrm{Cl}$ & $3.00 E+05$ & $1.17 E-14$ & $4.72 E-15$ & $2.07 E-15$ & $7.78 \mathrm{E}-16$ & $6.60 E-17$ \\
\hline${ }^{39} \mathrm{Ar}$ & $2.70 E+02$ & $2.49 E-11$ & $1.00 \mathrm{E}-02$ & $4.41 E-12$ & $1.66 \mathrm{E}-12$ & $1.40 E-13$ \\
\hline${ }^{41} \mathrm{Ca}$ & $1.00 E+05$ & 3. $13 \mathrm{E}-13$ & $5.36 E-13$ & $4.00 E-13$ & $2.07 \mathrm{E}-13$ & $1.10 E-14$ \\
\hline${ }^{53} \mathrm{Mn}$ & $3.70 E+06$ & $9.48 \mathrm{E}-14$ & $3.85 E-14$ & $1.68 \mathrm{E}-14$ & $6.30 E-15$ & $5.40 E-16$ \\
\hline $54 \mathrm{Mn}$ & $8.50 \mathrm{E}-01$ & 1. $23 \mathrm{E}-07$ & $4.97 E-08$ & $2.18 \mathrm{E}-08$ & $8.20 E-09$ & $6.90 E-10$ \\
\hline $55^{\mathrm{me}}$ & $2.70 E+00$ & $7.19 \mathrm{E}-06$ & $1.22 \mathrm{E}-05$ & $9.08 \mathrm{E}-06$ & $4.70 E-06$ & 2. $40 E-07$ \\
\hline${ }^{59} \mathrm{Ni}$ & $8.00 E+04$ & $4.42 E-11$ & $7.69 \mathrm{E}-11$ & $5.75 E-11$ & $2.99 E-11$ & $1.50 E-12$ \\
\hline${ }^{60} \mathrm{Co}$ & $5.30 E+00$ & $2.98 \mathrm{E}-07$ & $3.71 \mathrm{E}-07$ & $2.60 \mathrm{E}-07$ & l. $30 \mathrm{E}-07$ & $6.70 E-09$ \\
\hline $63 \mathrm{Ni}$ & $1.00 E+02$ & $5.40 \mathrm{E}-09$ & $9.52 \mathrm{E}-09$ & $7.13 E-09$ & $2.70 \mathrm{E}-09$ & $1.90 \mathrm{E}-10$ \\
\hline${ }^{55} \mathrm{Zn}$ & $6.70 \mathrm{E}-01$ & $1.77 E-09$ & $2.21 E-09$ & $1.55 \mathrm{E}-09$ & $7.80 E-10$ & 4.00E-11 \\
\hline${ }^{79} \mathrm{Se}$ & $6.50 E+04$ & $6.64 E-16$ & $6.55 E-165$ & $4.43 E-16$ & $2.20 E-16$ & 1.20E-17 \\
\hline $81^{\mathrm{Kr}}$ & $2.10 E+05$ & $<3.01 E-19$ & $<1.86 \mathrm{E}-19$ & $<6.60 E-20$ & $<1.40 E-20$ & $<3.60 E-23$ \\
\hline${ }^{85} \mathrm{Kr}$ & 1. $10 E+01$ & $<3.21 \mathrm{E}-12$ & $<2.00 E-12$ & $<1.20 E-12$ & $<5.30 E-13$ & $<3.30 E-14$ \\
\hline${ }^{90} \mathrm{Sr}$ & $2.90 E+01$ & $<1.43 \mathrm{E}-12$ & $<2.48 \mathrm{E}-12$ & $<1.85 E-12$ & $<9.60 \mathrm{E}-13$ & $<5.00 E-14$ \\
\hline $92 m_{\mathrm{Nb}}$ & $2.70 E+07$ & $<2.95 E-18$ & $<1.20 \mathrm{E}-18$ & $<5.20 E-19$ & $<2.70 E-19$ & $<2.20 E-20$ \\
\hline${ }^{93} \mathrm{Zr}$ & $9.50 E+05$ & $<4.30 E-16$ & $<5.00 E-16$ & $<3.10 E-16$ & $<1.50 \mathrm{E}-16$ & $<8.60 E-18$ \\
\hline $93 \mathrm{Mo}$ & $3.50 E+00$ & $1.99 \mathrm{E}-12$ & $9.60 \mathrm{E}-13$ & $4.20 E-13$ & $1.50 \mathrm{E}-13$ & $7.50 \mathrm{E}-15$ \\
\hline $94 \mathrm{Nb}$ & $2.00 E+04$ & $<5.69 \mathrm{E}-12$ & $<4.40 \mathrm{E}-12$ & $<2.65 E-12$ & $<1.20 \mathrm{E}-12$ & $<6.30 E-14$ \\
\hline${ }^{99} \mathrm{Ic}$ & $2.10 E+05$ & $4.46 \mathrm{E}-13$ & $2.10 \mathrm{E}-13$ & $8.70 E-14$ & $3.00 E-14$ & $1.50 E-15$ \\
\hline $108 m_{\mathrm{m}} \mathrm{Ag}$ & 1. $30 E+02$ & $6.47 E-12$ & $6.50 E-12$ & $4.30 E-12$ & 2. $10 \mathrm{E}-12$ & $1.10 E-13$ \\
\hline${ }^{121 m} \mathrm{sn}$ & $5.00 E+01$ & $3.90 \mathrm{E}-13$ & $1.58 \mathrm{E}-13$ & $6.90 E-14$ & $2.60 E-14$ & $2.20 \mathrm{E}-15$ \\
\hline${ }^{129} \mathrm{I}$ & $1.60 E+07$ & $<4.40 E-19$ & $<7.70 E-19$ & $<5.70 \mathrm{E}-19$ & $<3.00 \mathrm{E}-19$ & $<1.50 \mathrm{E}-20$ \\
\hline $133 \mathrm{Ba}$ & $1.00 E+01$ & $<5.53 \mathrm{E}-11$ & $<8.065 \mathrm{E}-11$ & $<6.30 E-11$ & $<3.30 \mathrm{E}-11$ & $<1.70 \mathrm{E}-12$ \\
\hline $134 \mathrm{Cs}$ & $2.10 E+00$ & $<3.93 \mathrm{E}-10$ & $<7.70 \mathrm{E}-10$ & $<5.80 \mathrm{E}-10$ & $<3.10 \mathrm{E}-10$ & $<1.60 E-11$ \\
\hline $135 \mathrm{Cs}$ & 2. $30 E+06$ & $<3.42 E-17$ & $\langle 5.10 \mathrm{E}-1\rangle$ & $<3.70 \mathrm{E}-1\rangle$ & $<1.90 \mathrm{E}-1\rangle$ & $1.00 \mathrm{E}-18$ \\
\hline $137 \mathrm{Cs}$ & $3.00 E+01$ & $<1.86 \mathrm{E}-12$ & $<2.70 \mathrm{E}-12$ & $<2.00 \mathrm{E}-12$ & $<1.00 \mathrm{E}-12$ & $<5.30 E-14$ \\
\hline & $1.80 E+01$ & $<1.86 \mathrm{E}-14$ & $<2.04 \mathrm{E}-14$ & $<1.50 \mathrm{E}-14$ & $<7.90 \mathrm{E}-15$ & $<4.20 E-16$ \\
\hline 14 & $1.00 E+08$ & $<1.64 E-21$ & $<6.60 E-22$ & $<2.90 \mathrm{E}-22$ & $<1.10 \mathrm{E}-22$ & $<9.20 E-24$ \\
\hline & $9.30 E+01$ & $<2.37 \mathrm{E}-12$ & $<2.60 E-12$ & $<1.75 E-12$ & $<8.60 \mathrm{E}-13$ & $<4.40 \mathrm{E}-14$ \\
\hline $152 \mathrm{Eu}$ & $1.30 E+01$ & $<3.92 E-09$ & $\langle 6.90 \mathrm{E}-09$ & $<5.20 E-09$ & $<2.70 \mathrm{E}-09$ & $<1.40 E-10$ \\
\hline $154 \mathrm{Eu}$ & $8.60 E+00$ & $<7.74 E-10$ & $<7.70 E-10$ & $<4.80 E-10$ & $<2.40 \mathrm{E}-10$ & $<1.20 \mathrm{E}-11$ \\
\hline $155_{\mathrm{Eu}}^{\mathrm{Lu}}$ & $4.80 E+00$ & $<2.83 \mathrm{E}-12$ & $<2.40 E-12$ & $<1.50 \mathrm{E}-12$ & $<6.90 \mathrm{E}-13$ & $<3.40 E-14$ \\
\hline 15 & $1.50 E+02$ & $<1.18 \mathrm{E}-13$ & $<4.80 \mathrm{E}-14$ & $<2.10 \mathrm{E}-14$ & $<7.90 E-15$ & $<6.60 E-16$ \\
\hline $166 \mathrm{~m}_{\mathrm{HC}}$ & $1.20 E+03$ & $<2.25 E-12$ & $<1.50 \mathrm{E}-12$ & $<8.20 E-13$ & $<3.60 \mathrm{E}-13$ & $<1.80 E-14$ \\
\hline $178 m_{H f}$ & $3.00 E+01$ & $<9.81 \mathrm{E}-12$ & $<5.60 E-12$ & $<2.80 \mathrm{E}-12$ & $<1.13 \mathrm{E}-12$ & $<5.70 \mathrm{E}-14$ \\
\hline & $1.40 E+07$ & $<5.04 \mathrm{E}-1\rangle$ & $\langle 4.44 E-1\rangle$ & $<2.90 \mathrm{E}-17$ & $<1.40 \mathrm{E}-1\rangle$ & $<7.70 \mathrm{E}-19$ \\
\hline & $1.60 E+05$ & $<3.85 E-14$ & $<2.50 E-14$ & $<1.40 \mathrm{E}-14$ & $<6.10 E-15$ & $<3.10 E-16$ \\
\hline & $2.40 E+04$ & $<1.02 \mathrm{E}-12$ & $<4.44 E-13$ & $<1.70 E-13$ & $<5.40 E-14$ & $<2.60 E-15$ \\
\hline
\end{tabular}


A comparison between maximum activation levels in the concrete matrix and the associated rebar is given in Table 5.8. For most activation products, the concrete matrix tends to dominate. Exceptions are those isotopes produced from $\mathrm{Fe}, \mathrm{Co}, \mathrm{Ni}, \mathrm{Mo}$, and $\mathrm{Ag}$. At a $10 \%$ rebar content, for example, the rebar would contribute about as much ${ }^{60} \mathrm{C}_{0}$ as the concrete, as well as contributing about three times as much ${ }^{63} \mathrm{Ni}$ and ${ }^{59} \mathrm{Ni}$. It should not represent any unusual problems, particularly if co-disposed with the concrete.

\subsubsection{Regulatory Considerations for Waste Disposal}

The U.S. Nuclear Regulatory Commission has recently adopted formal guidelines for classification of waste for shallow land disposal. These regulations are given in 10 CFR Part 61. Maximum levels are specified for several long lived radionuclides. The regulation also specifies that indirect methods may be used to determine the inventory of activation products of interest. The calculation method used in this study combined with chemical analys is and a normalization to at least one isotope such as ${ }^{60} \mathrm{Co}$ could thus be used for waste classification.

Several examples of this approach together with the appropriate regulatory limits from 10 CFR 61.55 are shown in Tables 5.9, 5.10, and 5.11 for comparison with expected maximum activation levels of the relevant isotopes. For all three cases the levels shown are at the point of maximum activation. Table 5.9 shows activity levels for PWR internals. The shroud clearly exceeds the Class $C$ concentrations on the basis of ${ }^{59} \mathrm{Ni}, 6{ }^{6} \mathrm{Ni},{ }^{94} \mathrm{Nb}$, and ${ }^{14} \mathrm{C}$ content. In particular, the ${ }^{63} \mathrm{Ni}$ level is about a factor of 20 above the maximum level classified as $\mathrm{Class} C$ waste. Since the nickel content is relatively constant in type 304 stainless steel, chemiçal variations wil not alter that conclusion. The 100 year half-life of $63 \mathrm{Ni}$ prevents large changes due to decay. The core barrel also appears to be marginally above the $\mathrm{Cl}$ ass $\mathrm{C}$ limit on the bas is of the ${ }^{63} \mathrm{Ni}$ content, although there are large uncertainties in the flux calculations. The vessel cladding would be classified as $C l$ ass $B$ waste based on its ${ }^{63} \mathrm{Ni}$ content. The vessel wall, with its considerably lower nickel content and lower flux, would clearly be a Class A waste. Table 5.10 lists the same type of comparisons for the BWR case. Again, according to this analysis, the shroud would not be classified as generally suitable for near surface disposal based on its ${ }^{59} \mathrm{Ni},{ }^{63} \mathrm{Ni}$, and ${ }^{94} \mathrm{Nb}$ content. The cladding and vessel would be Class $\mathrm{A}$ waste. It should be noted, however, that the isotope inventories calculated in this fashion pertain only to direct neutron activation. Vessel cladding, for example, may contain a radionuclide inventory dominated by translocation products associated with the surface corrosion film. In that case, the waste classification could be substantially different, but also potentially modifiable by decontamination. The bioshield results for the two geometries is shown on Table 5.11. Even for the highest levels produced at core axial midplane and $10 \mathrm{~cm}$ depth, this material should be classified as Class A or B for the PWR, 
TABLE 5.8. Comparison of Rebar Versus Concrete Matrix of PWR Bioshield 30 EFPY at Core Axial Midplane $10 \mathrm{~cm}$ Deep

\begin{tabular}{|c|c|c|c|c|}
\hline Isotope & Half-Life (Y) & Concrete & Kebar & Ratio \\
\hline${ }^{3} T$ & $1.20 E+01$ & $8.30 E-06$ & $4.10 E-08$ & 200.0 \\
\hline${ }^{14} \mathrm{C}$ & $5.70 E+03$ & $2.80 \mathrm{E}-09$ & $1.80 E-09$ & 1.6 \\
\hline${ }^{36} \mathrm{Cl}$ & $3.00 E+05$ & $1.50 E-19$ & $2.90 E-14$ & 5200.0 \\
\hline${ }^{39} \mathrm{Ar}$ & $2.70 E+02$ & $1.20 E-08$ & $6.20 E-11$ & 190.0 \\
\hline${ }^{41} \mathrm{Ca}$ & $1.00 E+05$ & $1.90 \mathrm{E}-08$ & $5.20 \mathrm{E}-12$ & 3700.0 \\
\hline $53_{M n}$ & $3.70 E+06$ & $7.40 E-15$ & $1.90 \mathrm{E}-13$ & 0.04 \\
\hline${ }^{54} \mathrm{Mn}$ & $8.50 E-01$ & $1.20 E-08$ & $3.00 E-07$ & 0.04 \\
\hline $55_{\mathrm{Fe}}$ & $2.70 E+00$ & 4.70E-06 & $1.20 E-04$ & 0.04 \\
\hline${ }^{59} \mathrm{Ni}$ & $8.00 E+04$ & $2.60 \mathrm{E}-11$ & $7.40 E-10$ & 0.04 \\
\hline${ }^{60} \mathrm{Co}$ & $5.30 \mathrm{E}+00$ & $3.60 E-07$ & $3.70 E-06$ & 0.10 \\
\hline${ }^{63} \mathrm{Ni}$ & $1.00 E+02$ & 3. 30E-09 & $9.30 E-08$ & 0.04 \\
\hline${ }^{65} \mathrm{Zn}$ & $6.70 E-01$ & $2.50 \mathrm{E}-09$ & $2.20 E-08$ & 0.11 \\
\hline${ }^{79} \mathrm{Se}$ & $6.50 E+04$ & $2.80 E-15$ & $5.50 E-15$ & 0.51 \\
\hline $81_{\mathrm{Kr}}$ & $2.10 E+05$ & $5.50 \mathrm{E}-17$ & $2.30 E-17$ & 2.40 \\
\hline $85 \mathrm{Kr}$ & $1.10 E+01$ & $4.20 \mathrm{E}-11$ & $<1.50 E-11$ & $>2.80$ \\
\hline${ }^{90} \mathrm{Sr}$ & $2.90 E+01$ & $7.30 \mathrm{E}-11$ & $<2.40 E-11$ & $>3.0$ \\
\hline $92 m_{N b}$ & $2.70 E+07$ & $1.20 \mathrm{E}-19$ & $<5.80 E-18$ & $>0.02$ \\
\hline${ }^{93} \mathrm{Zr}$ & $9.50 E+05$ & $2.90 E-14$ & $4.80 E-15$ & 6.0 \\
\hline $9^{93}$ & $3.50 E+00$ & $5.60 \mathrm{E}-13$ & $1.20 E-11$ & 0.05 \\
\hline${ }^{94} \mathrm{Nb}$ & $2.00 E+04$ & $5.30 \mathrm{E}-12$ & $<4.90 E-11$ & $>0.11$ \\
\hline${ }^{99} \mathrm{TC}$ & $2.10 E+05$ & $1.40 E-13$ & $<2.60 E-12$ & $>0.05$ \\
\hline${ }^{108 m_{A g}}$ & 1. $30 E+02$ & $<3.20 E-12$ & $6.80 E-11$ & $<0.05$ \\
\hline${ }^{121 m_{S n}}$ & $5.00 E+00$ & $<5.20 E-13$ & $8.40 E-13$ & $<0.62$ \\
\hline $129_{I}$ & $1.60 E+07$ & $2.20 E-17$ & $<8.00 E-18$ & $>2.9$ \\
\hline $133_{\mathrm{Ba}}$ & $1.00 E+01$ & $2.00 E-09$ & $<8.20 E-10$ & $>2.4$ \\
\hline${ }^{134} \mathrm{Cs}$ & 2. $10 E+00$ & $1.60 \mathrm{E}-08$ & $<7.30 \mathrm{E}-09$ & $>2.2$ \\
\hline${ }^{135} \mathrm{Cs}$ & 2. $30 E+06$ & $1.40 E-15$ & $<4.80 \varepsilon-16$ & $>2.9$ \\
\hline${ }^{137} \mathrm{Cs}$ & $3.00 E+01$ & $7.60 \mathrm{E}-11$ & $<2.60 E-11$ & $>2.9$ \\
\hline${ }^{145} \mathrm{Pm}$ & $1.80 E+01$ & $9.80 \mathrm{E}-12$ & $<2.00 E-13$ & $>49.0$ \\
\hline${ }^{146} \mathrm{Sm}$ & $1.00 E+08$ & $1.70 E-19$ & $<3.40 E-21$ & $>50.0$ \\
\hline${ }^{151_{\mathrm{Sm}}}$ & $9.30 E+01$ & $1.40 \mathrm{E}-09$ & $<2.90 E-11$ & $>48.0$ \\
\hline${ }^{152} \mathrm{Eu}$ & 1. $30 E+01$ & 3. $90 \mathrm{E}-07$ & $<6.40-08$ & $>6.1$ \\
\hline${ }^{154} \mathrm{Eu}$ & $8.60 E+00$ & $4.80 \mathrm{E}-08$ & $<7.80 E-09$ & $>6.2$ \\
\hline${ }^{155} \mathrm{Eu}$ & $4.80 E+00$ & $1.30 E-09$ & $<3.60 E-11$ & $>3.61$ \\
\hline${ }^{158} \mathrm{~Tb}$ & $1.50 E+02$ & $9.60 E-14$ & $<2.30 \mathrm{E}-13$ & $>0.42$ \\
\hline $166 \mathrm{~m}_{\mathrm{Ho}}$ & $1.20 E+03$ & 3. $90 \mathrm{E}-11$ & $<1.70 E-11$ & $>2.3$ \\
\hline $178 m_{H f}$ & $3.00 E+01$ & $1.80 \mathrm{E}-10$ & $<6.70 E-11$ & $>2.7$ \\
\hline${ }^{205} \mathrm{~Pb}$ & $1.40 E+07$ & $2.70 E-17$ & $<4.00 E-16$ & $>0.07$ \\
\hline $233 u$ & $1.60 E+05$ & $1.20 \mathrm{E}-11$ & $<2.90 E-13$ & $>41.4$ \\
\hline${ }^{239} \mathrm{Pu}$ & $2.40 \mathrm{E}+04$ & $1.70 \mathrm{E}-11$ & $<5.80 \mathrm{E}-12$ & $>2.93$ \\
\hline
\end{tabular}


TABLE 5.9. Classification of PWR Intervals for Low Level Waste Disposal - Core Axial Midplane - 30 EFPY, Activity in $\mathrm{Ci} / \mathrm{m}^{3}$ at Shutdown

\begin{tabular}{|c|c|c|c|c|c|c|c|}
\hline \multirow[b]{2}{*}{ Isotope } & \multirow[b]{2}{*}{ Shroud (d) } & \multirow{2}{*}{$\begin{array}{l}\text { Core }{ }^{(d)} \\
\text { Barrel } \\
\end{array}$} & \multirow{2}{*}{$\begin{array}{c}\text { Thermal }(d) \\
\text { Pads } \\
\end{array}$} & \multirow{2}{*}{$\begin{array}{l}\text { Vessel (d) } \\
\text { Cladding } \\
\end{array}$} & \multirow{2}{*}{$\frac{\text { Waste }}{\mathrm{A}}$} & \multicolumn{2}{|c|}{ Class $(\mathrm{a})$} \\
\hline & & & & & & $\mathrm{B}$ & $\mathrm{C}$ \\
\hline${ }^{3} T$ & 78 & 75 & 17 & 2.6 & 40 & (b) & (b) \\
\hline${ }^{14} \mathrm{C}$ & 195 & 23 & 3.6 & 0.5 & 8 & -- & 80 \\
\hline $\mathrm{T}_{1 / 2}<5 \mathrm{yr}(\mathrm{c})$ & $1.6 \mathrm{E} 6$ & $1.9 \mathrm{EE} 5$ & $2.9 E 4$ & $4.2 E 3$ & 700 & (b) & (b) \\
\hline${ }^{59} \mathrm{Ni}$ & 858 & 148 & 23 & 3.4 & 22 & -- & 220 \\
\hline${ }^{60} \mathrm{Co}_{0}$ & $1.0 \mathrm{E} 6$ & $1.1 \mathrm{E} 5$ & $1.6 \mathrm{E} 4$ & $2.6 \mathrm{E} 3$ & 700 & (b) & (b) \\
\hline${ }^{63} \mathrm{Ni}$ & $1.4 \mathrm{E} 5$ & $1.9 \mathrm{E} 4$ & 3000 & 420 & 35 & 700 & 7000 \\
\hline${ }^{94} \mathrm{Nb}$ & 3.1 & 0.23 & 0.023 & 0.006 & 0.02 & $\cdots$ & 0.2 \\
\hline${ }^{99} \mathrm{Tc}$ & 1.0 & 0.064 & 0.003 & 0.0018 & 0.3 & -. & 3 \\
\hline
\end{tabular}

(a) According to definitions established in 10 CFR Part 61.55.

(b) There are no limits established for these radionuclides in Class $B$ or $C$ waste. Practical considerations such as the effect of external radiation and heat generation on transportation, handling and disposal will limit the concentrations for these wastes.

(c) Dominant activation products with half-lives of $<5$ yf are ${ }^{55} \mathrm{Fe}$ and ${ }^{51} \mathrm{Cr}$. It is assumed for disposal purposes that the ${ }^{51} \mathrm{Cr}$ will be fully decayed.

(d) A density of $7.8 \times 10^{6} \mathrm{gm} / \mathrm{m}^{3}$ is used to convert activities into current units.

and Class A for the BWR. Most of the mass of the bioshield is of considerably lower levels of activation with much of the outer layers non-radioactive.

The above discussion is very general and simply serves as an example of the application of the 10 CFR 61 guidelines to the decommissioning problem with respect to the activated components. In practice, the situation is somewhat more complicated. In the examples given, average chemical compositions and volume averaged fluxes were used. In practice, some chemical analysis will be required to relate measured ${ }^{60}$ Co levels to the neutron flux in order to normalize the calculation. That should then allow a reasonably accurate estimate of the activation product inventory provided the material is reasonably homogeneous. That is not necessarily the case with certain types of reactor components such as control rods. Control rods pose a particularly difficult problem due to their high neutron opacity. The stainless steel cladding on the control 
TABLE 5.10. Classification of BWR Intervals for Low Level Waste Disposal - Core Axial Midplane - 30 EFPY, Activity in $\mathrm{Ci} / \mathrm{m}^{3}$ at Shutdown

\begin{tabular}{|c|c|c|c|c|c|}
\hline \multirow[b]{2}{*}{ Isotope } & \multirow[b]{2}{*}{ Shroud (d) } & Vessel $^{(d)}$ & \multicolumn{3}{|c|}{ Waste Class (a) } \\
\hline & & Cladding & & & $\mathrm{C}$ \\
\hline${ }^{3} \mathrm{~T}$ & 100 & 0.2 & 40 & (b) & (b) \\
\hline${ }^{14} \mathrm{C}$ & 57 & 0.04 & 8 & $\cdots$ & 80 \\
\hline $\mathrm{T}_{1 / 2}<5 \mathrm{yr}(\mathrm{c})$ & $4.6 \mathrm{E} 5$ & 320 & 700 & (b) & (b) \\
\hline $59 \mathrm{Ni}$ & 340 & 0.25 & 22 & -- & 220 \\
\hline${ }^{60} \mathrm{Co}_{\mathrm{O}}$ & $2.5 \mathrm{E5}$ & 190 & 700 & (b) & (b) \\
\hline${ }^{63} \mathrm{Ni}$ & 44500 & 31 & 35 & 700 & 7000 \\
\hline${ }^{94} \mathrm{Nb}$ & 0.49 & $3.8 E-4$ & 0.02 & -- & 0.2 \\
\hline${ }^{99} \mathrm{Tc}$ & 0.12 & $1.2 E-4$ & 0.3 & & 3 \\
\hline
\end{tabular}

(a) According to definitions established in 10 CFR Part 61.55.

(b) There are no limits established for these radionuclides in Class $B$ or $C$ waste. Practical considerations such as the effect of external radiation and heat generation on transportation, handling and disposal will limit the concentrations for these wastes.

(c) Pominant activation products with half-lives of $<5$ yr are ${ }^{51} \mathrm{Fe}$ and ${ }^{51} \mathrm{Cr}$. It is assumed for disposal purposes that the ${ }^{51} \mathrm{Cr}$ will be fully decayed.

(d) A density of $7.8 \times 10^{6} \mathrm{gm} / \mathrm{m}^{3}$ is used to convert activities into correct units.

rods should contain activity levels similar to that found in the shroud material and from that standpoint are presumably unsuitable for shallow land burial. PWR control rods contain an alloy of silver, cadmium, and indium and therefore may be expected to contain a large inventory of the 130 y $108 \mathrm{~m}_{\mathrm{Ag}}$; however, that isotope is not considered in 10 CFR 61. BWR control rods contain boron carbide. Some ${ }^{14} \mathrm{C}$ will undoubtedly be present due to neutron capture on ${ }^{13} \mathrm{C}$, but in all probability the activity in the cladding will predominate with $63 \mathrm{Ni}$ being the limiting isotope. 
TABLE 5.11. Classification of Bioshield Concrete for Low Level Waste Disposal - Core Axial Midplane - 30 EFPY, $10 \mathrm{~cm}$ Depth Activity in $\mathrm{Ci} / \mathrm{m}^{3}$ at Shutdown

\begin{tabular}{|c|c|c|c|c|c|}
\hline \multirow[b]{2}{*}{ Isotope } & \multirow[b]{2}{*}{ PWR } & \multirow[b]{2}{*}{ BWR } & \multicolumn{3}{|c|}{ Waste $\operatorname{class}(\mathrm{a})$} \\
\hline & & & $\bar{A}$ & $B$ & $\mathrm{C}$ \\
\hline${ }^{3} \mathrm{~T}$ & 25 & 2.6 & 40 & (b) & (b) \\
\hline${ }^{14} \mathrm{C}$ & 0.008 & $7.7 \mathrm{E}-4$ & 0.8 & --- & 8 \\
\hline$T_{1 / 2}<5 y(c)$ & 14 & 1.5 & 700 & (b) & $(b)$ \\
\hline${ }^{60} \mathrm{Co}$ & 1.1 & 0.10 & 700 & (b) & (b) \\
\hline${ }^{63} \mathrm{Ni}$ & 0.011 & 0.0011 & 3.5 & 70 & 700 \\
\hline${ }^{90} \mathrm{Sr}$ & $2.3 E-4$ & $2.3 E-5$ & 0.04 & 150 & 7000 \\
\hline${ }^{99} \mathrm{Tc}$ & $3.8 E-7$ & $3.8 \mathrm{E}-8$ & 0.3 & -- & 3 \\
\hline${ }^{129} 9_{I}$ & $7.6 \mathrm{E}-11$ & $7.6 \mathrm{E}-12$ & 0.008 & -- & 0.08 \\
\hline${ }^{137} \mathrm{Cs}$ & $2.3 E-5$ & $2.3 E-6$ & 1 & 44 & 4600 \\
\hline Transuranics & $3.8 E-5$ & $3.8 E-6$ & 0.08 & $\ldots$ & 0.8 \\
\hline
\end{tabular}

(a) According to definitions established in 10 CFR Part 61.55.

(b) There are no limits established for these radionuclides in Class $B$ or $C$ waste. Practical considerations such as the effect of external radiation and heat generation on transportation, handling and disposal will limit the concentrations for these wastes.

(c) Dominant activation products with half-lives of $<5$ yr are ${ }^{55} \mathrm{Fe}$ and ${ }^{51} \mathrm{Cr}$. It is assumed for disposal purposes that the ${ }^{51} \mathrm{Cr}$ will be fully decayed.

(d) A density of $3 \times 10^{6} \mathrm{gm} / \mathrm{m}^{3}$ is used to convert activities into correct units.

\subsection{RADIONUCLIDE INVENTORIES}

The specific activities for various isotopes given in Section 5.4 can be used to compute estimates of total isotope inventories. Since the neutron fluxes have already been volume averaged in computing the average specific activity, the only additional information required is the axial neutron distribution and the mass of the component included in that distribution. The parameters used are shown in Table 5.12. The PWR data was taken from Smith, Konzek, and Kennedy (1978). For the BWR case the data was taken from Oak et al. (1980). The calculated inventory for PWR internals is given in Table 5.13. It should be noted that this is not really a total inventory at shutdown since some short-lived activities such as ${ }^{51} \mathrm{Cr}$ and ${ }^{59} \mathrm{Fe}$ have not been included. The 
TABLE 5.12. Parameters Used for Radionuclide Inventory

\begin{tabular}{lccc} 
& Peak/Average & Mass of Component $(\mathrm{kg})$ \\
\cline { 2 - 2 } PWR Shroud & 0.755 & & 12,312 \\
PWR Core Barrel & 0.637 & 26,783 \\
PWR Thermal Pads & 0.778 & 10,413 \\
PWR Vessel Cladding & 0.637 & 2,074 \\
PWR Vessel Wall & 0.637 & 245,582 \\
BWR Shroud & 0.467 & 30,100 \\
BWR Vessel Cladding & 0.467 & 3440 \\
BWR Vessel Wall & 0.467 & 122,700
\end{tabular}

(a) Ratio of maximum activation at core axial midplane to average for entire component.

isotope inventory in the reactor internals is, of course, sharply dependent upon the time scale chosen. For the greater than one year time scale the total is $4.1 \mathrm{E} 6 \mathrm{Ci}$, more than $80 \%$ of which is in the shroud. The majority of the activity on that time scale is $55 \mathrm{Fe}$. For the greater than 5,100 , and 1000 year time scale the dominant activities are ${ }^{60} \mathrm{Co}, 6{ }^{\mathrm{Ni}}$, and ${ }^{59} \mathrm{Ni}$, respectively. Inventories of long-lived activation products in reactor internals at shutdown are listed in Table 5.13 and 5.14. The comparable data for PWR and BWR vessel walls is given in Table 5.15. In order to calculate an inventory for the bioshield, some information on depth-dependent production rates is needed. This is shown in Figure 5.16 for PWR concrete. Maximum activation occurs at around $10 \mathrm{~cm}$ depth for most isotopes due to increasing neutron thermalization up to that point. Some minor differences in the profile do occur depending on the production mechanism. For example, ${ }^{154}$ Eu which has a very large resonance contribution and ${ }^{39} \mathrm{Ar}$ which is produced entirely by fast neutrons do not exhibit that peaking behavior. In any case it is quite clear from Figure 5.15 that essentially all of the activated concrete is contained within 30 to $50 \mathrm{~cm}$ of the inner edge of the bioshield. To calculate a total inventory from Figure 5.15, a $10 \%$ rebar component was added and a numerical integration carried out over the outer $75 \mathrm{~cm}$ of the bioshield in $5 \mathrm{~cm}$ increments for a $502 \mathrm{~cm}$ vertical section of the shield. The axial integration factor for the vessel was also included. A similar calculation was carried out for a $451 \mathrm{~cm}$ segment of a BWR sacrificial shield. Activity inventories are summarized in Table 5.16. Long-lived activation product inventories of reactor internals are somewhat lower for the BWR than the PWR due to the core design. The activation product inventory for the bioshield is actually about one order of magnitude lower for the BWR due to the considerably reduced neutron fluxes. 
TABLE 5.13. Activity Inventory of PWR Internals at Shutdown (Total Ci)

\begin{tabular}{|c|c|c|c|c|c|}
\hline Isotope & Half-Life (Y) & Shroud & $\begin{array}{c}\text { Core } \\
\text { Barrel }\end{array}$ & $\begin{array}{c}\text { Thermal } \\
\text { Pads }\end{array}$ & $\begin{array}{c}\text { Vessel } \\
\text { Cladding } \\
\end{array}$ \\
\hline${ }^{3}{ }_{T}$ & $1.20 E+01$ & $9.30 E+01$ & $1.64+02$ & $1.79 E+01$ & $4.40 E-01$ \\
\hline${ }^{14} \mathrm{C}$ & $5.70 E+03$ & $2.32 E+02$ & $5.10 E+01$ & $3.70 E+00$ & $3.70 t-02$ \\
\hline${ }^{36} \mathrm{Cl}$ & $3.00 E+05$ & $4.70 E+00$ & $1.10 E+00$ & $8.10 E-02$ & $\therefore .25 E-03$ \\
\hline${ }^{39} \mathrm{Ar}$ & $2.70 E+02$ & $<1.40 E+00$ & $<1.4 U E-01$ & $<3.00 E-03$ & $\langle 3,4\rangle, . . \cup 4$ \\
\hline${ }^{41} \mathrm{Ca}$ & $1.00 E+05$ & $<4.30 E-02$ & $<9.55 t-03$ & $<6.97 \mathrm{E}-04$ & $<1.60$ it-25 \\
\hline $53_{M n}$ & $3.70 E+06$ & $3.00 E-02$ & $3.60 E-03$ & $8.10 E-05$ & $9.00 \mathrm{E}-06$ \\
\hline${ }^{54} \mathrm{Mn}$ & $8.50 E-01$ & $6.04 E+04$ & $6.14 E+03$ & $1.46 E+02$ & $1.58 t+01$ \\
\hline${ }^{55} \mathrm{Fe}$ & $2.70 E+00$ & $1.95 E+06$ & $4.09 E+05$ & $3.00 E+04$ & $7.13 E+02$ \\
\hline${ }^{59} \mathrm{Ni}$ & $8.00 t+04$ & $1.02 E+03$ & $3.24 E+02$ & $2.43 E+01$ & $5.7 \cup E-U 1$ \\
\hline${ }^{60} \mathrm{Co}$ & $5.30 E+00$ & $1.21 E+06$ & $2.39 E+05$ & $1.62 E+04$ & $4.36 E+02$ \\
\hline${ }^{63} \mathrm{Ni}$ & $1.00 E+02$ & $1.68 E+05$ & $4.09 E+04$ & $3.08 E+03$ & $7.13 E+U 1$ \\
\hline${ }^{65} \mathrm{Zn}$ & $6.70 E-01$ & $5.95 E+03$ & $6.78 E+02$ & $4.78 E+01$ & $1.30 E+00$ \\
\hline${ }^{79} \mathrm{Se}$ & $6.50 E+04$ & $5.70 E-03$ & $7.85 E-04$ & $3.80 E-05$ & $2.00 E-06$ \\
\hline $81_{\mathrm{Kr}}$ & $2.10 E+05$ & $<7.10 E-03$ & $<5.80 E-05$ & $\langle 2.84 \mathrm{E}-0\rangle$ & $<2.77 E-09$ \\
\hline $85_{\mathrm{Kr}}$ & $1.10 E+01$ & $<7.90 \mathrm{E}+00$ & $<3.24 \mathrm{E}-01$ & $<7.70 E-03$ & $<1.72 E-04$ \\
\hline${ }^{90} \mathrm{Sr}$ & $2.90 E+01$ & $<1.86 E+01$ & $<8.50 E-02$ & $<2.10 c^{\prime}-02$ & $<4.76 \mathrm{E}-04$ \\
\hline $92 m \mathrm{Nb}$ & $2.70 E+07$ & $1.10 \mathrm{E}-05$ & $1.00 E-06$ & $2.59 E-08$ & $2.64 E-09$ \\
\hline${ }^{93} \mathrm{Zr}$ & $9.50 E+05$ & $1.00 E-03$ & $6.70 E-05$ & $2.00 E-06$ & $1.13 E-07$ \\
\hline $9^{93}$ Mo & $3.50 E+00$ & $8.70 E+00$ & $6.65 E-01$ & $1.7 U E-02$ & $1.50 E-03$ \\
\hline${ }^{94} \mathrm{Nb}$ & $2.00 E+04$ & $3.70 E+00$ & $4.95 E-01$ & $2.40 E-02$ & $9.90 E-04$ \\
\hline${ }^{99} \mathrm{TC}$ & $2.10 E+05$ & $1.20 E+00$ & $1.40 E-01$ & $3.40 E-03$ & $3.17 E-04$ \\
\hline $108 \mathrm{~m}_{\mathrm{Ag}}$ & 1. $30 E+02$ & $<9.30 \mathrm{E}-01$ & $<1.50 E-01$ & $<8.90 E-03$ & $<2.91 E-04$ \\
\hline${ }^{12} \operatorname{lm}_{\mathrm{Sn}}$ & $5.00 E+00$ & $4.40 E-02$ & $5.80 E-03$ & $1.38 E-04$ & $1.50 E-U 5$ \\
\hline${ }^{129} \mathrm{I}$ & $1.60 E+07$ & $<6.00 E-06$ & $\langle 2.39 E-0\rangle$ & $<6.40 E-09$ & $<1.45 E-10$ \\
\hline $133_{\mathrm{Ba}}$ & $1.00 E+01$ & $<2.70 E+01$ & $<5.11 E+00$ & $<3.60 E-01$ & $<9.40 E-04$ \\
\hline${ }^{134} \mathrm{Cs}$ & $2.10 E+00$ & $<6.50 \mathrm{E}+01$ & $<1.70 \mathrm{E}+01$ & $<1.37 E+00$ & $<3.00 E-02$ \\
\hline${ }^{135} \mathrm{Cs}$ & $2.30 E+06$ & $<4.00 E-04$ & $<1.50 E-05$ & $\langle 4.10 E-0\rangle$ & $<1.03 E-08$ \\
\hline${ }^{137} \mathrm{Cs}$ & $3.00 E+01$ & $<1.90 \mathrm{E}+01$ & $<8.50 \mathrm{E}-0 \mathrm{l}$ & $<2.20 E-02$ & $<5.55 E-04$ \\
\hline${ }^{145} \mathrm{Pm}$ & $1.80 E+01$ & $<8.00 \mathrm{E}-03$ & $<2.39 E-03$ & $<1.78 t-04$ & $<4.00 E-06$ \\
\hline${ }^{146} \mathrm{Sm}$ & $1.00 E+08$ & $9.30 E-10$ & $2.21 E-10$ & $5.50 E-12$ & $5.70 E-13$ \\
\hline $151_{S m}$ & $9.30 E+01$ & $4.30 E-02$ & $7.70 E-02$ & 2. $30 E-02$ & $7.80 E-04$ \\
\hline${ }^{152} \mathrm{Eu}$ & $1.30 E+01$ & $0.00 E+00$ & $1.55 E-02$ & $1.38+00$ & $1.00 E-01$ \\
\hline${ }^{154} \mathrm{Eu}$ & $8.60 E+00$ & $5.20 E+00$ & $1.02 E+01$ & $5.00 E-01$ & $1.60 E-02$ \\
\hline${ }^{155} \mathrm{Eu}$ & $4.80 E+00$ & $3.80 E+00$ & $2.39 E+00$ & $4.05 E-02$ & $6.90 E-04$ \\
\hline${ }^{158} \mathrm{~Tb}$ & $1.50 E+02$ & $1.80 E-02$ & $2.90 E-03$ & $6.90 E-04$ & $7.00 E-06$ \\
\hline $166 \mathrm{~m}_{\mathrm{Ho}}$ & $1.20 E+03$ & $1.50 E+1)$ & $2.21 E-01$ & $8.90 E-03$ & 4. $00 E-04$ \\
\hline $178 m_{H f}$ & $3.00 E+01$ & $\langle 4.00 E-01$ & $<4.77 \varepsilon-01$ & $<2.50 \mathrm{E}-02$ & $<1.60 E-03$ \\
\hline $205 \mathrm{~Pb}$ & $1.40 E+07$ & $1.70 \mathrm{E}-05$ & $2.00 E-06$ & $1.05 E-07$ & $4.50 E-09$ \\
\hline $233 \mathrm{U}$ & $1.60 E+05$ & $<3.30 E-03$ & $<1.70 E-03$ & $<8.90 E-05$ & $<4.00 E-06$ \\
\hline${ }^{239} \mathrm{Pu}$ & $2.40 E+04$ & $<6.50 \mathrm{E}-02$ & $<3.92 \mathrm{E}-02$ & $<1.0 \mathrm{E}-03$ & $<1.27 E-04$ \\
\hline
\end{tabular}


TABLE 5.14. Activity Inventory of BWR Internals at Shutdown (Total Ci)

\begin{tabular}{|c|c|c|c|}
\hline Isotope & Half-Life (Y) & Shroud & $\begin{array}{c}\text { Vessel } \\
\text { Cladding } \\
\end{array}$ \\
\hline$\overline{3_{T}}$ & $1.20 E+01$ & $\overline{1.83 E+02}$ & $1.40 E-02$ \\
\hline${ }^{14} \mathrm{C}$ & $5.70 E+03$ & $1.03 E+02$ & $2.80 E-03$ \\
\hline${ }^{36} \mathrm{Cl}$ & $3.00 E+05$ & $2.24 E+00$ & $5.70 E-05$ \\
\hline${ }^{39} \mathrm{Ar}$ & $2.70 E+02$ & $<2.67 \mathrm{E}-01$ & $<3.00 E-05$ \\
\hline${ }^{41} \mathrm{Ca}$ & $1.00 E+05$ & $2.00 E-02$ & $5.20 \mathrm{E}-07$ \\
\hline $53 \mathrm{Mn}$ & $3.70 E+06$ & $6.50 E-03$ & $8.00 \mathrm{E}-07$ \\
\hline${ }^{54} \mathrm{Mn}$ & $8.50 \mathrm{E}-01$ & $1.17 E+04$ & $1.14 E+00$ \\
\hline${ }^{55} \mathrm{Fe}$ & $2.70 E+00$ & $9.29 E+05$ & $2.36 \mathrm{E}+01$ \\
\hline${ }^{59} \mathrm{Ni}$ & $8.00 E+04$ & $6.04 E+02$ & $1.80 E-02$ \\
\hline${ }^{60} \mathrm{Co}$ & $5.30 E+00$ & $4.50 E+05$ & $1.38 E+01$ \\
\hline $63_{\mathrm{Ni}}$ & $1.00 E+02$ & $8.01 E+04$ & $2.30 E+00$ \\
\hline${ }^{65} \mathrm{Zn}$ & $6.70 E-01$ & $1.55 E+03$ & 4. $10 \mathrm{E}-02$ \\
\hline${ }^{79} \mathrm{Se}$ & $6.50 E+04$ & $1.40 E-03$ & $9.80 E-08$ \\
\hline $81_{\mathrm{Kr}}$ & $2.10 E+05$ & $<2.24 \mathrm{E}-04$ & $<5.40 \mathrm{E}-12$ \\
\hline $85_{\mathrm{Kr}}$ & $1.10 E+01$ & $<8.15 E-01$ & $<5.00 E-06$ \\
\hline${ }^{90} \mathrm{Sr}$ & $2.90 E+01$ & $<2.11 E+00$ & $<1.40 E-05$ \\
\hline $92 m_{\mathrm{Nb}}$ & $2.70 E+07$ & $6.33 E-07$ & $2.20 E-10$ \\
\hline $93 \mathrm{Zr}$ & $9.50 E+05$ & $1.41 E-04$ & $6.90 \mathrm{E}-09$ \\
\hline${ }^{93} \mathrm{MO}_{\mathrm{M}}$ & $3.50 E+00$ & $1.08 E+00$ & $4.40 E-05$ \\
\hline${ }^{94} \mathrm{Nb}$ & $2.00 E+04$ & $8.86 \mathrm{E}-01$ & $2.80 \mathrm{E}-05$ \\
\hline${ }^{99} \mathrm{TC}$ & $2.10 E+05$ & $2.10 E-01$ & $9.00 E-06$ \\
\hline $108 m_{A g}$ & $1.30 E+02$ & $<2.18 E-01$ & $<9.00 E-06$ \\
\hline${ }^{121 m} \mathrm{sn}$ & $5.00 E+00$ & $1.07 E-02$ & $1.00 E-06$ \\
\hline${ }^{129} \mathrm{I}$ & $1.60 E+07$ & $<5.90 \mathrm{E}-07$ & $<4.40 E-12$ \\
\hline $133_{\mathrm{Ba}}$ & $1.00 \mathrm{E}+01$ & $<1.0 r E+01$ & $<3.50 E-04$ \\
\hline${ }^{134} \mathrm{Cs}$ & $2.10 E+00$ & $<3.37 E+01$ & $<9.80 E-04$ \\
\hline${ }^{135} C_{s}$ & $2.30 E+06$ & $<3.80 E-04$ & $<3.67 \mathrm{E}-10$ \\
\hline${ }^{137} \mathrm{Cs}$ & $3.00 E+01$ & $<2.11 E+00$ & $<2.00 E-05$ \\
\hline${ }^{145} \mathrm{Pm}$ & $1.80 E+01$ & $<4.40 E-03$ & $\langle 1.30 \mathrm{E}-0\rangle$ \\
\hline${ }^{146} 6_{S m}$ & $1.00 E+08$ & $4.07 E-10$ & $4.50 E-14$ \\
\hline${ }^{151} \mathrm{Sm}$ & 9. $30 E+01$ & 5. $30 \mathrm{E}-02$ & $1.80 \mathrm{E}-05$ \\
\hline${ }^{152} \mathrm{Eu}$ & 1. $30 \mathrm{E}+01$ & $3.09 \mathrm{E}-07$ & $3.85 E-03$ \\
\hline${ }^{154} \mathrm{Eu}$ & $8.60 E+00$ & $1.28 E+01$ & $4.60 E-04$ \\
\hline${ }^{155_{\mathrm{Eu}}}$ & $4.80 E+00$ & $5.06 E+00$ & 1.70E-05 \\
\hline${ }^{158} \mathrm{~Tb}$ & $1.50 E+02$ & $5.30 E-03$ & $6.31 E-07$ \\
\hline $166 \mathrm{~m}_{\mathrm{Ho}}$ & $1.20 E+03$ & $3.93 \mathrm{E}-01$ & $1.10 E-05$ \\
\hline $178 m_{H f}$ & $3.00 E+01$ & $<5.20 \mathrm{E}-01$ & $<4.30 \mathrm{E}-05$ \\
\hline $205 \mathrm{~Pb}$ & 1. $40 \mathrm{E}+07$ & $4.00 E-06$ & $2.58 E-10$ \\
\hline $233_{U}$ & $1.60 E+05$ & $<2.25 \mathrm{E}-03$ & $<1.30 \mathrm{E}-07$ \\
\hline${ }^{239} \mathrm{Pu}$ & $2.40 E+04$ & $<3.80 \mathrm{E}-02$ & $<3.00 \mathrm{E}-06$ \\
\hline
\end{tabular}


TABLE 5.15. Activity Inventories of PWR and BWR Vessel Walls at Shutdown (Total $\mathrm{C} i$ )

\begin{tabular}{|c|c|c|c|}
\hline Isotope & Half-Life (Y) & PWR & BWK \\
\hline$\overline{3}$ & $1.20 E+01$ & $1.70 E+01$ & $6.10 E-02$ \\
\hline${ }^{14} \mathrm{C}$ & $5.70 E+03$ & $2.80 \mathrm{E}-01$ & $1.20 E-02$ \\
\hline${ }^{36} \mathrm{Cl}$ & $3.00 E+05$ & $1.70 \mathrm{E}-02$ & $1.43 \mathrm{E}-04$ \\
\hline${ }^{39} \mathrm{Ar}$ & $2.70 E+02$ & $<3.70 E-02$ & $<1.10 \mathrm{E}-03$ \\
\hline${ }^{41} \mathrm{Ca}$ & $1.00 E+05$ & $2.20 E-04$ & $2.00 E-06$ \\
\hline $53 \mathrm{Mn}$ & $3.70 E+06$ & $4.06 \mathrm{E}-04$ & $1.00 E-05$ \\
\hline${ }^{54} \mathrm{Mn}$ & $8.50 E-01$ & $6.08 E+01$ & $1.27 \mathrm{E}+01$ \\
\hline${ }^{55} \mathrm{Fe}$ & $2.70 E+00$ & $1.87 E+04$ & $1.14 E+02$ \\
\hline${ }^{59} \mathrm{Ni}$ & $8.00 E+04$ & $6.55 E-01$ & $8.00 E-02$ \\
\hline${ }^{60} \mathrm{Co}$ & $5.30 E+00$ & $1.17 E+03$ & $9.55 E+01$ \\
\hline${ }^{63} \mathrm{Ni}$ & $1.00 E+02$ & $7.96 \mathrm{E}+01$ & $9.55 E+00$ \\
\hline $65 \mathrm{zn}$ & $6.70 E-01$ & $8.74 E+00$ & $2.90 E-02$ \\
\hline${ }^{79} \mathrm{Se}$ & $6.50 E+04$ & $7.90 \mathrm{E}-07$ & $1.00 \mathrm{E}-06$ \\
\hline $81_{\mathrm{Kr}}$ & $2.10 E+05$ & $<2.80 E-08$ & $<3.04 E-11$ \\
\hline $85_{\mathrm{Kr}}$ & $1.10 E+01$ & $<3.00 E-02$ & $<2.20 E-05$ \\
\hline${ }^{90} \mathrm{Sr}$ & $2.90 E+01$ & $<8.30 E-04$ & $<6.10 \mathrm{E}-05$ \\
\hline $92 m_{N b}$ & $2.70 E+07$ & $1.29 \mathrm{E}-08$ & $2.90 E-09$ \\
\hline $93 \mathrm{Zr}$ & $9.50 E+05$ & $3.00 E-06$ & $8.10 E-08$ \\
\hline $93_{\text {Mo }}$ & $3.50 E+00$ & $2.30 \mathrm{E}-01$ & 7. $96 \mathrm{E}-04$ \\
\hline${ }^{94} \mathrm{Nb}$ & $2.00 E+04$ & 1. 10E-02 & $7.20 \mathrm{E}-05$ \\
\hline${ }^{99} \mathrm{TC}$ & $2.10 E+05$ & $5.50 E-02$ & $1.59 E-04$ \\
\hline $108 m_{A g}$ & 1. $30 E+02$ & $<1.15 \mathrm{E}-02$ & $<7.80 E-05$ \\
\hline${ }^{121 \mathrm{~m}} \mathrm{sn}$ & $5.00 E+00$ & $3.90 E-04$ & $1.40 \mathrm{E}-05$ \\
\hline $129_{I}$ & $1.60 E+07$ & $<2.50 \mathrm{E}-10$ & $1.88 \mathrm{E}-12$ \\
\hline $133_{\mathrm{Ba}}$ & $1.00 E+01$ & $<1.00 E-01$ & $<2.20 \mathrm{E}-03$ \\
\hline${ }^{134} \mathrm{Cs}$ & $2.10 E+00$ & $<2.70 \mathrm{E}-01$ & $<3.50 E-03$ \\
\hline${ }^{135} \mathrm{Cs}$ & $2.30 E+06$ & $<3.60 E-08$ & $<2.46 \mathrm{E}-09$ \\
\hline${ }^{137} \mathrm{Cs}$ & $3.00 E+01$ & $<2.00 \mathrm{E}-03$ & $<1.38 \mathrm{E}-04$ \\
\hline${ }^{145} \mathrm{Pm}$ & $1.80 E+01$ & $<1.20 E-05$ & $<9.41 E-08$ \\
\hline${ }^{146} \mathrm{Sm}$ & $1.00 E+08$ & 3. $00 \mathrm{E}-12$ & $6.20 \mathrm{E}-13$ \\
\hline${ }^{151_{S m}}$ & 9. $30 E+01$ & 3. $70 \mathrm{E}-03$ & $1.45 E-04$ \\
\hline${ }^{152} \mathrm{Eu}$ & $1.30 E+01$ & $3.12 E+00$ & $1.70 E-02$ \\
\hline${ }^{154} \mathrm{Eu}$ & $8.60 E+00$ & $1.01 E+00$ & $4.50 E-03$ \\
\hline${ }^{155} \mathrm{Eu}$ & $4.80 E+00$ & $6.09 E-03$ & $1.88 \mathrm{E}-04$ \\
\hline${ }^{158} \mathrm{~Tb}$ & $1.50 E+02$ & $2.20 \mathrm{E}-04$ & $8.00 E-06$ \\
\hline $166 m_{\mathrm{HO}}$ & $1.20 E+03$ & $2.00 E-02$ & $1.59 E-04$ \\
\hline $178 m_{\mathrm{HF}}$ & $3.00 E+01$ & $<1.15 E-02$ & $<7.09 E-04$ \\
\hline $205 \mathrm{pb}$ & $1.40 E+07$ & $2.00 E-06$ & $3.04 E-09$ \\
\hline $233 u$ & $1.60 E+05$ & $<5.00 E-05$ & $<2.00 E-06$ \\
\hline${ }^{239} \mathrm{pu}$ & $2.40 E+04$ & $<1.10 E-03$ & $<6.80 E-05$ \\
\hline
\end{tabular}


TABLE 5.16. Activity Inventory Summary

\begin{tabular}{|c|c|c|c|c|c|c|}
\hline \multirow{2}{*}{$\begin{array}{l}\text { Isotope } \\
\text { Half-Life } \\
\end{array}$} & \multicolumn{2}{|c|}{ Internals } & \multicolumn{2}{|c|}{ Vesse 1} & \multicolumn{2}{|c|}{ Bioshield } \\
\hline & PWR & BWR & PWR & PWR & 0.110 & BWR \\
\hline$>1$ year & $4.1 E 6$ & $1.4 \mathrm{E} 6$ & 2.0E4 & 2020 & $4.7 \mathrm{E3}$ & 376 \\
\hline$>5$ years & $1.7 \mathrm{E} 6$ & $5.3 \mathrm{E} 5$ & $1.3 \mathrm{E} 3$ & 14 & $1.7 \mathrm{E} 3$ & 146 \\
\hline$>100$ years & $2.1 E 5$ & $8.1 E 4$ & 81 & 0.88 & 3 & 0.3 \\
\hline$>1000$ years & $2.0 \mathrm{E} 3$ & 770 & 1.7 & 0.019 & 3 & 0.3 \\
\hline
\end{tabular}




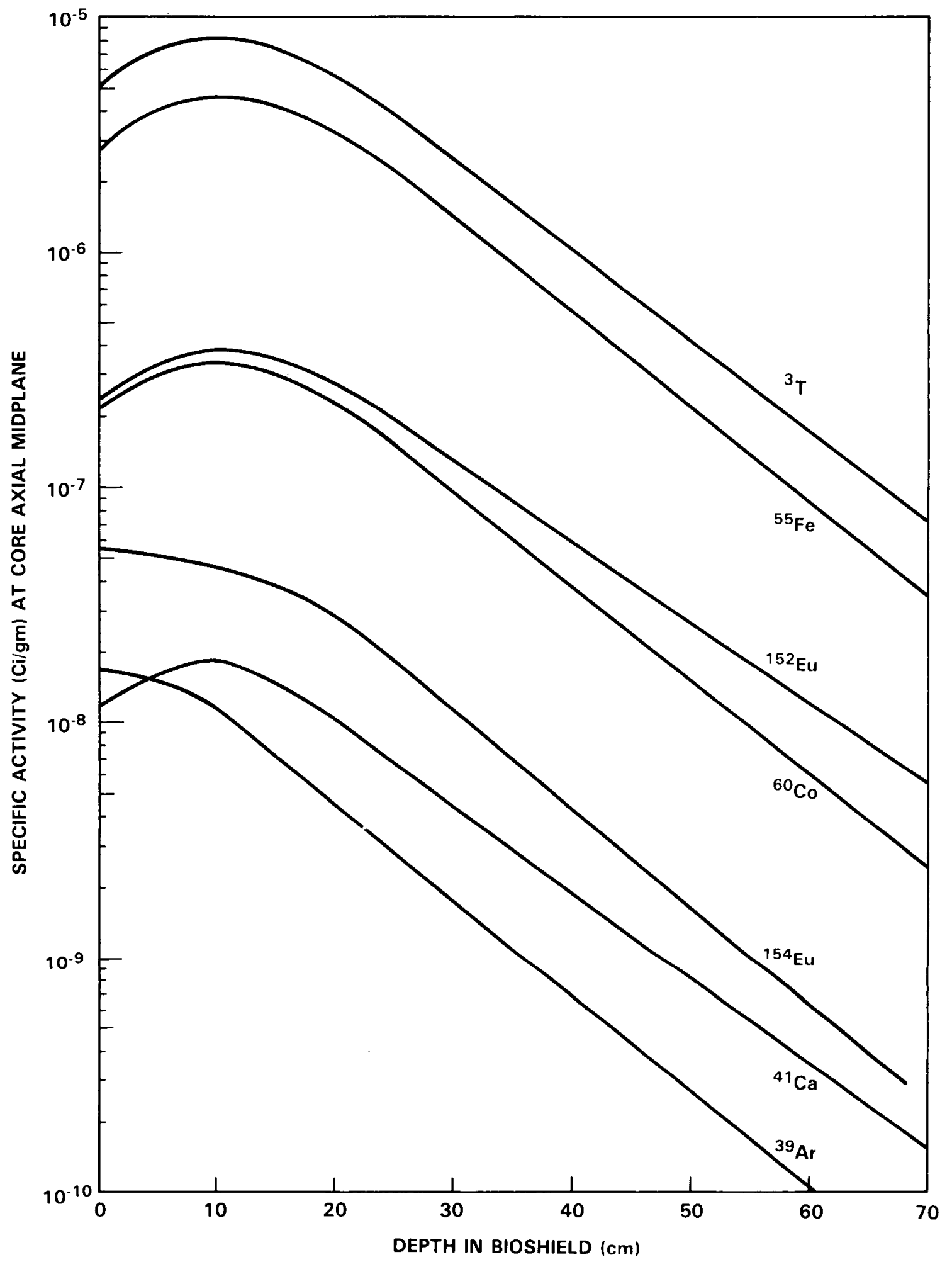

FIGURE 5.16. PWR Bioshield Average Concrete Activity Versus Depth 30 EFPY Operation 
$$
\text { . }
$$ 


\subsection{RADIOCHEMICAL ANALYSIS PROGRAM}

Throughout the course of this work, samples of activated reactor components were sought to provide verification of the calculation method. Ideal samples were, in general, not available from operating reactors although some useful samples of opportunity were obtained. Several shutdown reactors including Pathfinder, Humboldt Bay, and Indian Point No. 1 were also included in the programs. The terms of the operating license for these reactors prevents any serious sampling effort from taking place at this time for either bioshield or internals samples, however. A major effort was undertaken at Pathfinder to obtain a core through the bioshield in the area adjacent to the reactor core region. This ultimately proved infeasible with the facilities and contamination controls available. Such a task would be relatively simple during an actual dismantling operation. Concrete samples were taken from accessible levels at the Pathfinder, Humboldt Bay and Turkey Point No. 4 reactors; however, they were from areas of highly reduced flux with only a limited radiochemical analysis possible.

\subsection{SAMPLES ANALYZED}

The following is a brief description of the samples subjected to a limited radiochemical analysis.

\section{1 .1 Steels}

Point Beach No. 1 Fuel Support Structure

Samples of $304 \mathrm{~L}$ stainless steel and Type 718 Inconel were cut from a fuel support structure originating in the Point Beach No. 1 reactor (a 497 MWe Westinghouse PWR). The fuel bundle (B25) was removed from the reactor on 5/10/74 after two cycles of irradiation running from $11 / 2 / 72$ to $9 / 29 / 72$ and $3 / 3 / 73$ to 4/6/74. The samples were removed from the fuel bundle during a series of nuclear waste vitrification studies at PNL. The samples were extremely radioactive, representing a difficult handling problem even after eight years decay. Drill turnings were taken in a shielded glove box for XRF and radiochemical analysis. The remainder of the sample was archived. XRF analysis of the Inconel sample showed it to be very high in stable niobium (5\%) making it useful for the determination of ${ }^{94} \mathrm{Nb}$. Niobium was in fact detectable in this sample by a simple gamma scan without chemical separation from the ${ }^{60} \mathrm{Co}$.

\section{Monticello Core Spray Sparger Pin}

Support pins from the Monticello Reactor (a 545 MWe GE BWR) were removed during a scheduled maintenance outage. The pins were located on the vessel 
wall $287 \mathrm{~cm}$ above the top of the reactor core. This sample thus corresponds reasonably well to the flux calculations for BWR vessel cladding given in Section 5.4.1, but at a significantly reduced flux level. The period of radiation was from November 1975 to October 1977. One of the pins was shipped to PNL for analysis. The pin is fabricated from type 304L stainless steel. It was cut into several pieces. with samples of both ends taken for radiochemical analysis. The sample posed no unusual handling problems, particularly after the corrosion film had been stripped off.

\section{Westinghouse - EPRI Surveillance Capsule Samples}

A number of activated vessel steel samples were obtained through a pressure vessel surveillance program run by Westinghouse for EPRI. The samples were provided by Westinghouse at the request of EPRI. The samples consisted of both base metal and welds. All appeared to be very similar in composition and thus a limited selection was analyzed for radiochemistry. The samples had been irradiated in the University of Virginia reactor for periods up to 1 year to simulate PWR conditions. The samples were irradiated as close as possible to the core face. A stainless steel sample of the surveillance capsule itself was also provided. That sample was composed on reactor grade type 304L stainless steel and is thus typical of reactor internals.

\subsubsection{Concretes}

Pathfinder

A $7.5 \mathrm{~cm}$ diameter core of the concrete floor directly beneath the pressure vessel was taken from the Pathfinder reactor (An Allis-Chalmers 58.5 MWe boiling water reactor which had operated for a 42 month period up to September 1967). The core was sliced into $1 \mathrm{~cm}$ sections for gamma counting. The lower section of the core was ground in a shatterbox for radiochemical analysis.

Humboldt Bay

Four samples were chipped from the top and bottom of the shield ring in the dry well surrounding the Humboldt bay reactor (a 65 MWe GE BWR which operated from 1963 until July 1, 1976).

Turkey Point No. 4

An extensive sampling progrm was carried out at the Turkey Point Generating Station in October 1981 during an outage for steam generator replacement. During that outage it was possible to gain access to the sump region directly beneath the pressure vessel on Unit 4 about $24 \mathrm{hr}$ after shutdown. The Turkey Point Unit 4 Reactor is a 693 MWe Westinghouse PWR which has been in operation since 1973. In spite of high temperatures and high 
radiation fields in the sump area, it was possible to obtain two $7.5 \mathrm{~cm}$ diameter concrete cores from the sump floor. The samples were sliced into $1 \mathrm{~cm}$ sections for gamma counting and were also subjected to radiochemistry after grinding in a shatterbox.

\subsection{ANALYTICAL METHODS}

\subsubsection{Nondestructive Gamma Assay}

Concrete core samples were cut into $1 \mathrm{~cm}$ slabs using a rock saw with a diamond-impregnated cutting wheel. The individual slices were then repackaged in plastic and mounted directly on the face of a $100 \mathrm{~cm}^{3} \mathrm{Ge}(\mathrm{Li})$ diode for counting. The counter was standardized using a mockup prepared in an identical geometry and matched density. The mockup was made from a mixture of epoxy, powdered iron, and powdered aluminum doped with a mixture of NBS or NBStraceable liquid radioisotope standards. Standards for ${ }^{60} \mathrm{Co},{ }^{125} \mathrm{Sb},{ }^{137} \mathrm{Cs}$, $152,154,155 \mathrm{Eu}$ and $207 \mathrm{Bi}$ were included. An efficiency curve was prepared from those peaks using a regression fit.

Counting results were reduced using a standard peak identification, peak area routine with the efficiency curve used for this final quantification. All reported results have been decay corrected to the time of last known irradiation and corrected for a saturation factor corresponding to a 30 year irradiation.

\subsubsection{Radiochemical Separations and Countings}

Samples of steel and concrete were digested in hot hydrochloric acid. Sample size varied from $10 \mathrm{mg}$ to $50 \mathrm{gm}$ depending upon the specific activity of ${ }^{60} \mathrm{Co}$ in the sample. The solutions were filtered and diluted to constant volume. An aliquot was taken for gamma assay of $54 \mathrm{Mn},{ }^{60} \mathrm{Co}$, and ${ }^{137} \mathrm{Cs}$. Aliquots of the remaining sample were subjected to radiochemical separations as described below.

\subsubsection{1 ${ }^{55} \mathrm{Fe}$ Determination}

Iron isotopes were separated from other radionuclides by anion exchange chromatography. Iron was electroplated onto a copper disc from an ammonium oxalate medium. Radiochemical yields were determined by tracing with $59 \mathrm{Fe}$. Iron-55 was measured using an intrinsic germanium diode with a 5 mil beryllium window to detect the characteristic manganese $K X$-rays. 


\subsubsection{2 ${ }^{63} \mathrm{Ni}$ and ${ }^{59} \mathrm{Ni}$ Determination}

Nickel isotopes were separated from other radionuclides by precipitating with dimethyl-glyoxime in the presence of chelating agents and hold-back carriers. Nickel was electroplated onto a stainless steel disc from a sulfate medium. Chemical yields were determined by tracer technique using $2.52 \mathrm{hr}$ 65 $\mathrm{Ni}$. Nickel-63 was measured using an anti-coincident shielded windowless proportional beta counter. Nickel-59 was measured using an intrinsic germanium diode with a $5 \mathrm{mil}$ beryllium window to detect the characteristic cobalt $k$ $x$-rays.

\section{$6.2 .2 .3 \quad 93$ Mo Determination}

Molybdenum isotopes were separated from other radionuclides by repeated scavenging with ferric hydroxide, ether extractions, and anion exchange chromatography. Molybdenum was electroplated onto a stainless steel disc from a basic sulfate medium. Radiochemical yields were determined by tracing with 99 Mo. Molybdenum-93 was measured using an intrinsic germanium diode with a $5 \mathrm{mil}$ beryllium window to detect the characteristic niobium $\mathrm{K} X$-rays.

\subsubsection{4 ${ }^{94} \mathrm{Nb}$ Determination}

Niobium was separated from other radionuclides by precipitation of niobic oxide from an acid medium during dissolution of the solid sample. Both niobium carrier and ${ }^{95} \mathrm{Nb}$ were present during dissolution. Niobium-94 was measured by gamma-ray spectrometric techniques and radiochemical yield determined by tracing with ${ }^{95} \mathrm{Nb}$.

\subsubsection{5 ${ }^{99} \mathrm{TC}$ Determination}

Technetium isotopes were separated from other radionuclides by scavenging methods and anion exchange chromatography. Technetium was electroplated from a basic ammonium sulfate medium. Technetium-99 was corrected for radiochemical yield by tracing with $95 \mathrm{~m}_{\mathrm{Tc}}$. Technetium- 99 was determined by beta absorption techniques using a windowless beta proportional counter that was anticoincident shielded to reduce background.

\subsubsection{Europium Isotopes}

Europium radionuclides were separated along with other rare earth isotopes by precipitating with hydrofluoric acid in an acid medium using rare earth carriers and hold-back carrier. Radiochemical yields were determined by tracer techniques using $140 \mathrm{La}$. Europium-152, ${ }^{154} \mathrm{Eu}$, and ${ }^{155} \mathrm{Eu}$ were measured by gammaray spectrometric techniques with a $100 \mathrm{~cm}^{3} \mathrm{Ge}(\mathrm{Li})$ diode. 


\subsection{RADIOCHEMICAL ANALYSIS RESULTS}

\section{3 .1 Steels}

The results of the radiochemical analysis of stainless steel samples are given in Table 6.1. Three of the samples are type 304L stainless steel, the material most typical of reactor internals, while the fourth is type 718 inconel. The inconel sample is very high in both stable nickel and niobium thus making it an ideal case for studying the production of the long-lived activation products from those elements, $i . e .,{ }^{59} \mathrm{Ni}, 63^{\mathrm{Ni}}$, and ${ }^{94} \mathrm{Nb}$. All of the results given in this section are corrected for decay to the end of irradiation and adjusted to an equivalent of 30 years of irradiation. Calculations were carried out using the previously described computer codes combined with the individual sample compositions as measured by $X$-ray fluorescence. For the Monticello sample, the flux calculation for BWR vessel cladding was used, while for the other three, conditions typical of a PWR shroud were used. In all cases this procedure resulted in a significant overestimate of the thermal flux. In order to have a point of reference for the actual neutron received by the samples, all calculations were normalized to the measured ${ }^{55} \mathrm{Fe}$ in each sample. It should be noted that this will mainly serve to scale the thermal neutron flux, since ${ }^{55} \mathrm{Fe}$ is produced primarily by thermal neutron capture. Normalizing to ${ }^{55} \mathrm{Fe}$ results in overall agreement to within a factor of two in most cases. In view of the less than ideal sampling conditions, this can be considered to be reasonably good agreement. A few curious anomalies did appear, however. In particular, the ${ }^{94} \mathrm{Nb}$ measurement from the Point Beach inconel sample is considerably higher than expected. The SS304L sample from the same area is also a bit higher in ${ }^{94} \mathrm{Nb}$ than expected. This could suggest that the cross-section used in the calculation is in error, however, a more likely explanation lies in the details of the flux distribution. Those two samples came from the core of the reactor where there is a particularly high epithermal neutron component, and a significantly lower cadmium ratio than in the shroud. Niobium-94 does have a substantial resonance contribution to its production rate. It is worth noting that $93 \mathrm{Mo}$, which is produced almost entirely by resonance capture is also underpredicted in the Point Beach samples and overpredicted in the samples from the University of Virginia and the Monticello reactors. Clearly, better documented samples are required to obtain more accurate results. Agreement between the measured and calculated activities for $54 \mathrm{Mn}$, and $63_{\mathrm{Ni}}$ was rather poor for the Monticello core spray sparger pin sample. The reason for the disagreement is not apparent.

The equivalent results for vessel steels is given in Table 6.2. All four samples were of similar composition irradiated under similar though not identical conditions in a research reactor. Good agreement was obtained for ${ }^{54} \mathrm{Mn}$, ${ }^{60} \mathrm{Co}$, and ${ }^{63} \mathrm{Ni}$. Molybdenum-93 is in all four cases overpredicted by up to a factor of four presumably due to the reasons previously discussed. It was 


\section{TABLE 6.1. Irradiated Stainless Steel - Measured Versus Calculated Activity}

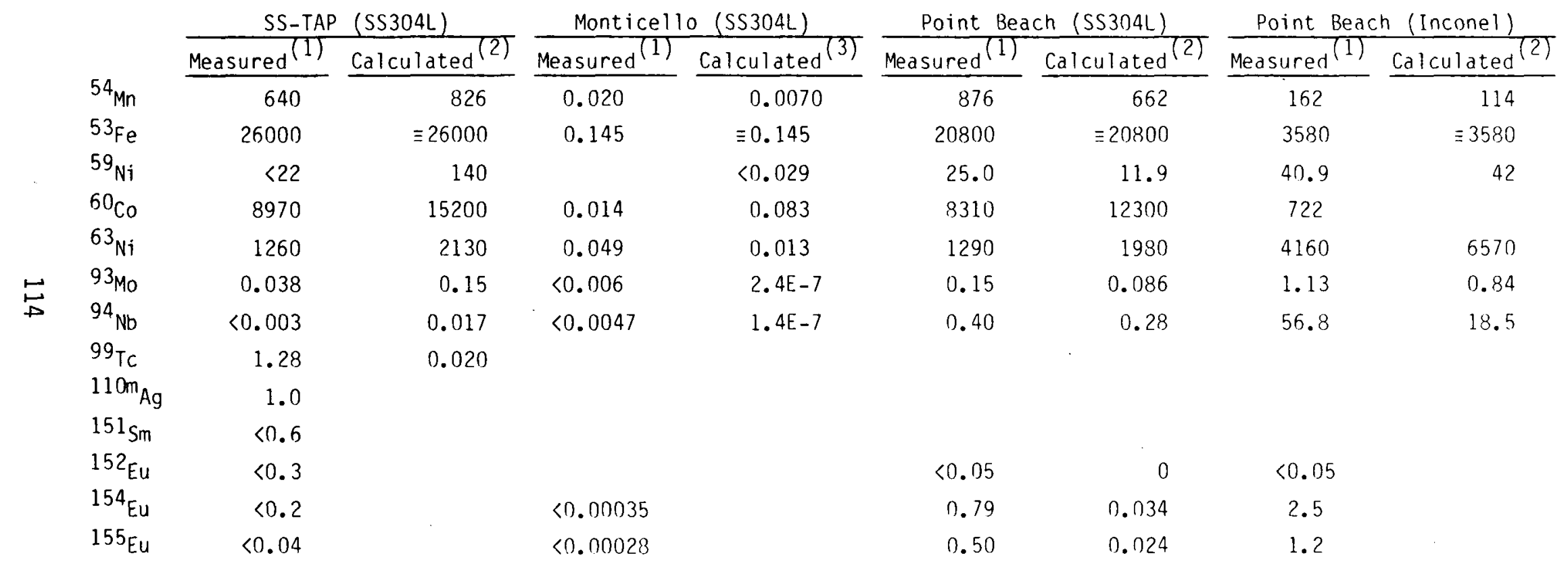

(1) Corrected $t_{1}$ end of irrąiation and 30 EFPY

(2) Normalized "o measured $55 \mathrm{Fe}$. Based on measured composition and flux conditions for PWR shroud

(3) Normalized to measured ${ }^{55} \mathrm{Fe}$. Based on measured composition and flux conditions for BWR vessel cladding. 
TABLE 6.2. Irradiated Vessel Steels - Measured Versus Calculated Activity in $\mu \mathrm{Ci} / \mathrm{gm}$

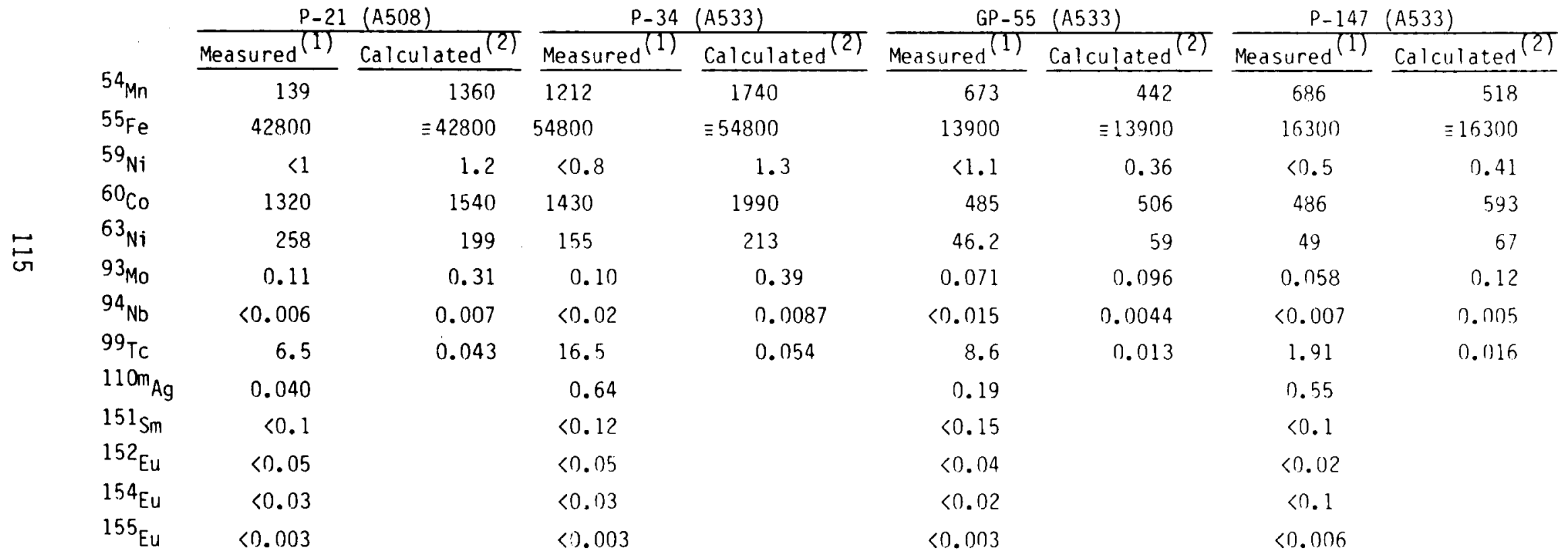

(1) Corrected to end of irradiation and 30 EFPY

(2) Normalized to measured ${ }^{55} \mathrm{Fe}$. Based on measured composition and flux conditions for Pwk shroud 
not possible to measure ${ }^{59} \mathrm{Ni}$ or ${ }^{94} \mathrm{Nb}$ in these samples with adequate sensitivity to check the model for those isotopes. All of the samples were rather high in ${ }^{99} \mathrm{Tc}$. This is evidently some type of contamination since it is clearly too high to be the result of direct activation.

\subsubsection{Concretes}

Radiochemical analyses were carried out on a series of concrete samples obtained at the Pathfinder, Humboldt Bay, and Turkey Point No. 4 reactors. Data for the concretes was treated in the same manner as previously described for the steels with the exception that 152Eu was used for neutron flux normalization rather than $55 \mathrm{Fe}$. None of the samples available for analysis were really fully satisfactory. Since access to the more highly activated regions of the bioshield was not possible at any of the sites sampled, it was necessary to obtain samples from regions receiving highly attenuated neutron fluxes. In addition to the fact that detection limits become a serious problem experimentally, contamination by translocation products can be dominant for some isotopes, particularly near the surface of the concrete. This is illustrated in Table 6.3 and Figure 6.1 which plots the depth profile of the cobalt and europium isotopes in a concrete core taken directly beneath the reactor vessel at the Pathfinder reactor. The europium is clearly a pure activation product while the ${ }^{60}$ Co near the surface is obviously a translocated contaminant. The ${ }^{60}$ Co activity appears to be leveling off near the pure activation level, but does not quite reach it. The core is also seen from Table 6.4 to be contaminated with ${ }^{55} \mathrm{Fe}$ even 8 centimeters beneath the surface. This situation is even more obvious for the data on the Humboldt Bay samples as given in Tables 6.5 and 6.6. While the two europium isotopes show good internal consistency as

TABLE 6.3. Pathfinder Concrete Core PCC-8 Directly Beneath Vessel Activity in $\mathrm{pCi} / \mathrm{gm}$ Corrected to Shutdown and $30 \mathrm{EFPY}$

\begin{tabular}{|c|c|c|c|c|}
\hline Depth $(\mathrm{cm})$ & ${ }^{60} \mathrm{Co}_{\mathrm{O}}$ & ${ }^{63} \mathrm{Ni}$ & ${ }^{152} \mathrm{Eu}$ & ${ }^{154} \mathrm{Eu}$ \\
\hline $0-1$ & 3200 & & 5.93 & 1.20 \\
\hline $1-2$ & 76.0 & & 5.84 & 1.14 \\
\hline $2-3$ & 39.1 & & 6.37 & 1.30 \\
\hline $3-4$ & 40.2 & & 6.68 & 1.14 \\
\hline $4-5$ & 21.4 & & 6.68 & 1.09 \\
\hline $5-6$ & 21.8 & & 8.46 & 1.35 \\
\hline $6-7$ & 16.5 & & 7.84 & 1.35 \\
\hline $7-8$ & 17.6 & & 8.24 & 1.40 \\
\hline $8-9$ & 14.6 & $<400$ & 7.84 & 1.35 \\
\hline
\end{tabular}




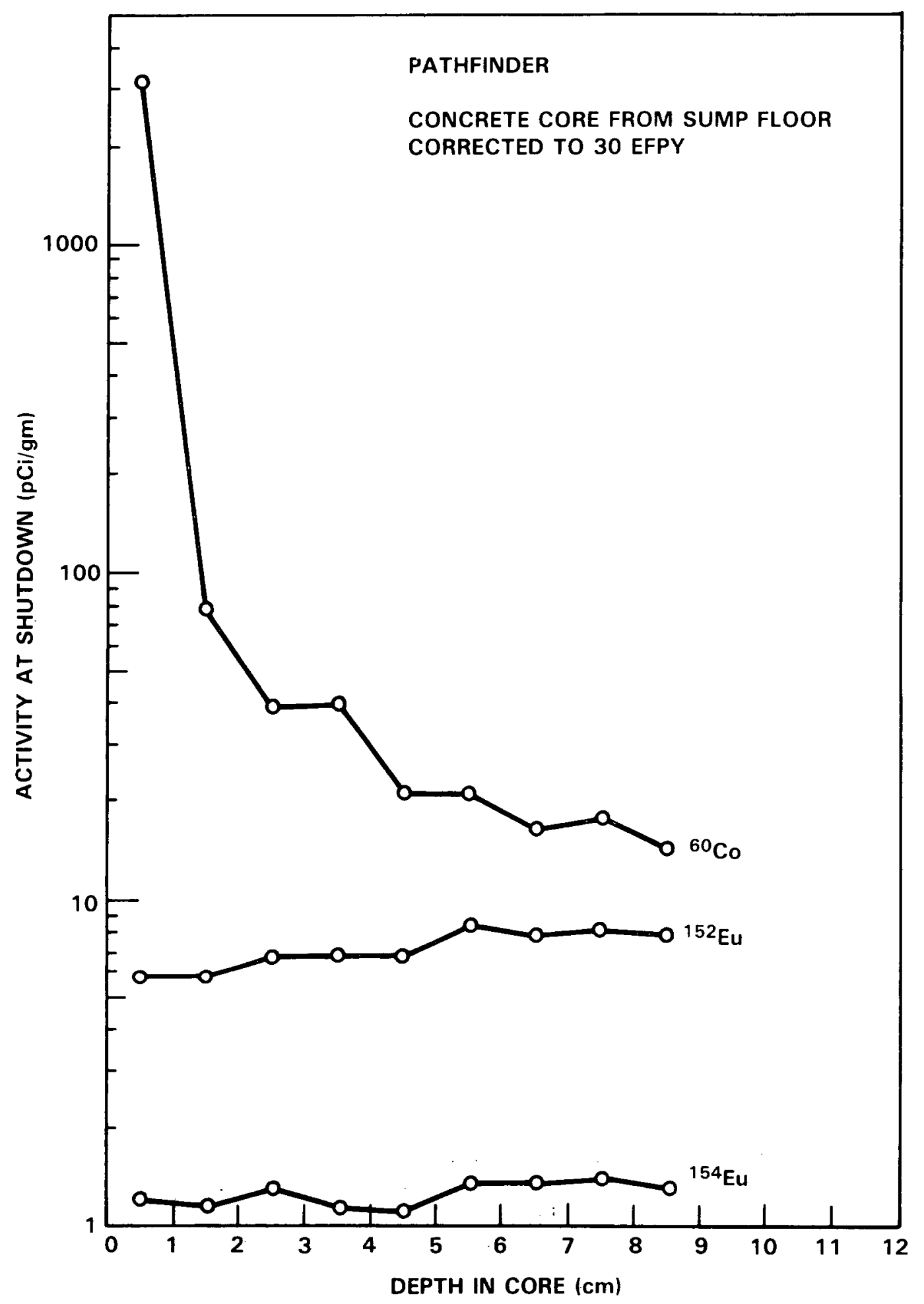

FIGURE 6.1. Depth Profile of Radionuclides in Concrete Core Taken from Sump Floor at Pathfinder 
TABLE 6.4. Pathfinder Concrete Core PCC-8 $(8-9 \mathrm{~cm})$ Comparison of Measured and Calculated Activities

\begin{tabular}{|c|c|c|c|}
\hline & $\begin{array}{l}\text { Measured } \\
(\mathrm{pCi} / \mathrm{gm}) \\
\end{array}$ & $\begin{array}{c}\text { Calcul ated } \\
(\mathrm{pCi} / \mathrm{gm}) \\
\end{array}$ & $\begin{array}{l}\text { Measured/ } \\
\text { Calculated }\end{array}$ \\
\hline${ }^{55} \mathrm{Fe}$ & 16000 & 73 & 220 \\
\hline${ }^{60} \mathrm{Co}_{\mathrm{O}}$ & 14.6 & 3.7 & 4.0 \\
\hline${ }^{63} \mathrm{Ni}$ & $<400$ & 0.2 & \\
\hline $152_{E u}$ & 7.84 & $\equiv 7.84$ & $\equiv 1$ \\
\hline${ }^{154} \mathrm{Eu}$ & 1.35 & 0.85 & 1.6 \\
\hline
\end{tabular}

TABLE 6.5. Humboldt Bay Concrete Bioshield Samples Activity at Shutdown and $30 \mathrm{EFPY}$ ( $\mathrm{pCi} / \mathrm{gm}$ )

HBRS-22

$\frac{{ }^{54} \mathrm{Mn}}{42.7} \frac{55_{\mathrm{Fe}}}{378} \frac{{ }^{60} \mathrm{Co}}{{ }^{63_{\mathrm{Ni}}}} \frac{125_{\mathrm{Sb}}}{0.45} \frac{{ }^{134} \mathrm{Cs}}{8.2} \frac{{ }^{137} \mathrm{Cs}}{199} \frac{152_{\mathrm{Eu}}}{188} \frac{154_{\mathrm{Eu}}}{11.6} \frac{{ }^{155_{\mathrm{Eu}}}}{2.2}$

Bottom

Inside

Edge

HBRS-23

25.7

821

$1.67 \quad 30.1 \quad 475$

309

$18.1 \quad 3.61$

Bottom

Inside

Edge

HBRS-24

$39.7 \quad 7380 \quad 303$

55

1.41

51.0

544

63

$4.9 \quad 0.80$

Top Outside

Edge

HBRS-25

Top Inside

$176 \quad 16600 \quad 1308$

$41<0.7 \quad 153$

72

293

31.6

5.3

Edge

pure activation products, everything else appears to be contamination. The best samples obtained were those taken beneath the pressure vessel at the Turkey Point No. 4 reactor. Since these samples were taken immediately after shutdown it was possible to measure a number of shorter-lived activation products in addition to the rather limited list of long-lived isotopes detectable. Two cores were analyzed with the saturation and decay corrected results given in Tables 6.7 and 6.8. The data for core TP-I is plotted as a function of depth in Figure 6.2. Most of the isotopes show only shallow penetration of contamination from the surface. A notable exception is ${ }^{137} \mathrm{Cs}$ which exhibits a much less rapid fall off with depth, with considerable contamination present in 


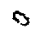

TABLE 6.6. Humboldt Bay Concrete from Upper Shield Ring

HBRS-25 Comparison of Measured and

Calculated Activities

$\begin{array}{lrrr}{ }_{54} & \begin{array}{r}\text { Measured } \\ (\mathrm{pCi} / \mathrm{gm})\end{array} & \begin{array}{c}\text { Calculated } \\ (\mathrm{pCi} / \mathrm{gm})\end{array} & \begin{array}{r}\text { Measured } \\ \text { Calculated }\end{array} \\ { }^{55} \mathrm{Fe} & 176 & 8.5 & 21 \\ { }^{60} \mathrm{Co} & 16600 & 2080 & 8.0 \\ { }^{63} \mathrm{Ni} & 1308 & 233 & 5.6 \\ { }^{134} \mathrm{Cs} & 153 & 2.9 & 14 \\ { }^{152} \mathrm{Eu} & 293 & 9293 & 17 \\ 154_{\mathrm{Eu}} & 31.6 & 31.7 & \equiv 1.0 \\ 155_{\mathrm{Eu}} & 5.3 & 0.7 & 1.0\end{array}$

even the deepest sample. Table 6.9 gives a comparison with the activation model for the deepest point in core TP-I. Agreement is excellent for most of the isotopes.

\subsubsection{Conclusions}

Within the framework of the samples available, only a limited verification of the predictive capability was possible. In the steel samples, ${ }^{59} \mathrm{Ni},{ }^{63} \mathrm{Ni}$, and 93 Mo were found to be present at approximately the expected levels based on a neutron flux normalization. The presence of $94^{4} \mathrm{Nb}$ in stainless steel samples was verified at levels somewhat higher than expected. The discrepancy appears to be attributable to epithermal capture in the core region for those particular samples. For the concrete samples, the dominant role of the europium isotopes was verified, with good agreement between measurement and calculation obtained for a number of shorter-lived isotopes. It was not possible to determine ${ }^{41} \mathrm{Ca}$ with the available techniques on the rather low level samples obtainable at this time. 


\begin{tabular}{|c|c|c|c|c|c|c|c|}
\hline & $0-1$ & $1-2$ & $2-3$ & $3-4$ & $4-5$ & $5-6$ & $6-7$ \\
\hline${ }^{46} \mathrm{Sc}$ & 1001 & 1350 & 1390 & 1380 & 1360 & 1450 & 1300 \\
\hline${ }^{51} \mathrm{Cr}$ & 8140 & 4830 & 1835 & 626 & 580 & 440 & 450 \\
\hline $54_{M n}$ & 76 & 3.1 & 3.1 & 4.0 & 1.8 & $<1.8$ & $<1.8$ \\
\hline${ }^{55} \mathrm{Fe}$ & 12800 & 14500 & 14500 & & & & 18675 \\
\hline${ }^{58} \mathrm{Co}$ & 165 & 19 & 22 & 19 & 17 & 23 & 25 \\
\hline${ }^{59} \mathrm{Fe}$ & 670 & 780 & 820 & 780 & 780 & 810 & 720 \\
\hline $\begin{array}{l}{ }^{60} \mathrm{Co} \\
{ }^{63} 3_{\mathrm{Ni}}\end{array}$ & 10100 & 1700 & 1400 & 1420 & 1430 & 1540 & $\begin{array}{r}1320 \\
<16\end{array}$ \\
\hline${ }^{65} \mathrm{Zn}$ & 630 & 61 & 53 & 54 & 59 & 52 & 50 \\
\hline${ }^{94} \mathrm{Nb}$ & $<3$ & $<2$ & $<2$ & $<2$ & $<2$ & $<2$ & $<2$ \\
\hline $108 m_{\mathrm{Ag}}$ & $<3$ & $<2$ & $<2$ & $<2$ & $<2$ & $<2$ & $<2$ \\
\hline $110 \mathrm{~m}_{\mathrm{Ag}}$ & 13 & $<5$ & $<5$ & $<5$ & $<5$ & $<5$ & 5 \\
\hline${ }^{124} \mathrm{Sb}$ & 49 & 20 & 19 & 17 & 12 & 8.5 & 12.5 \\
\hline${ }^{134} \mathrm{Cs}$ & 500 & 188 & 116 & 85 & 80 & 72 & 58 \\
\hline${ }^{137} \mathrm{Cs}$ & 6550 & 1610 & 772 & 471 & 353 & 224 & 133 \\
\hline${ }^{14} 1_{\mathrm{Ce}}$ & 63 & 98 & 85 & 80 & 80 & 89 & 54 \\
\hline${ }^{152} \mathrm{Eu}$ & 2490 & 4010 & 4170 & 4090 & 3860 & 4210 & 3670 \\
\hline${ }^{154} \mathrm{Eu}$ & 346 & 470 & 470 & 390 & 370 & 440 & 350 \\
\hline${ }^{155} \mathrm{Eu}$ & $<13$ & $<42$ & $<30$ & $<27$ & $<27$ & $<33$ & $<33$ \\
\hline $166 \mathrm{~m}_{\mathrm{Ho}}$ & $<6$ & $<20$ & $<14$ & $<13$ & $<13$ & $<16$ & $<16$ \\
\hline
\end{tabular}


TABLE 6.8. Turkey Point Unit 4 Concrete Core Taken Directly Beneath Vessel (TR-J) Activity at Shutdown and 30 EFPY $(\mathrm{pC} \mathbf{j} / \mathrm{gm})$

\begin{tabular}{|c|c|c|c|c|c|c|c|c|}
\hline & $0-1$ & $1-2$ & $2-3$ & $3-4$ & $4-5$ & $5-6$ & $6-7$ & $7-8$ \\
\hline${ }^{46} S c$ & 1024 & 1266 & 1323 & 1560 & 1190 & 2203 & 1502 & 1703 \\
\hline${ }^{51} \mathrm{Cr}$ & 3667 & 1390 & 760 & 890 & 580 & 670 & 490 & 850 \\
\hline $54_{M n}$ & 49 & $<2$ & 2.7 & $<2$ & 7.6 & 12.5 & 8.9 & $<1.8$ \\
\hline${ }^{58} \mathrm{Co}$ & 134 & 19 & 25 & 26 & 12 & 23 & 21 & 36 \\
\hline${ }^{59} \mathrm{Fe}$ & 680 & 740 & 780 & 890 & 2120 & 4510 & 2850 & 950 \\
\hline${ }^{60} \mathrm{Co}$ & 8090 & 1590 & 1540 & 1708 & 3300 & 6226 & 4310 & 1710 \\
\hline${ }^{65} \mathrm{Zn}$ & 2420 & 79 & 83 & 83 & 80 & 84 & 84 & 100 \\
\hline${ }^{94} \mathrm{Nb}$ & $<1.7$ & $<0.6$ & $<0.6$ & $<0.6$ & $<0.6$ & $<1.0$ & $<1.0$ & $<0.6$ \\
\hline $108 m_{A g}$ & $<0.8$ & $<0.6$ & $<0.6$ & $<0.6$ & $<1.1$ & $<0.6$ & $<0.6$ & $<0.6$ \\
\hline $110 \mathrm{~m}_{\mathrm{Ag}}$ & $<10$ & $<8$ & $<5$ & $<7$ & $<7$ & $<9$ & $<7$ & $<5$ \\
\hline${ }^{124} \mathrm{Sb}$ & 72 & 31 & 21 & 22 & 12 & 17 & 17 & 22 \\
\hline${ }^{134} \mathrm{Cs}$ & 530 & 115 & 77 & 86 & 53 & 57 & 67 & 67 \\
\hline${ }^{137} \mathrm{Cs}$ & 3190 & 165 & 80 & 76 & 32 & 28 & 35 & 27 \\
\hline${ }^{141_{\mathrm{Ce}}}$ & 54 & 63 & 67 & 38 & 76 & 103 & 98 & 72 \\
\hline${ }^{152} \mathrm{Eu}$ & 3041 & 4440 & 4080 & 4870 & 3400 & 3730 & 4370 & 5280 \\
\hline${ }^{154} \mathrm{Eu}$ & 810 & 1100 & 950 & 1170 & 740 & 775 & 980 & 1100 \\
\hline $166 \mathrm{~m}_{\mathrm{Ho}}$ & $<13$ & $<20$ & $<23$ & $<20$ & $<23$ & $<33$ & $<10$ & $<15$ \\
\hline
\end{tabular}




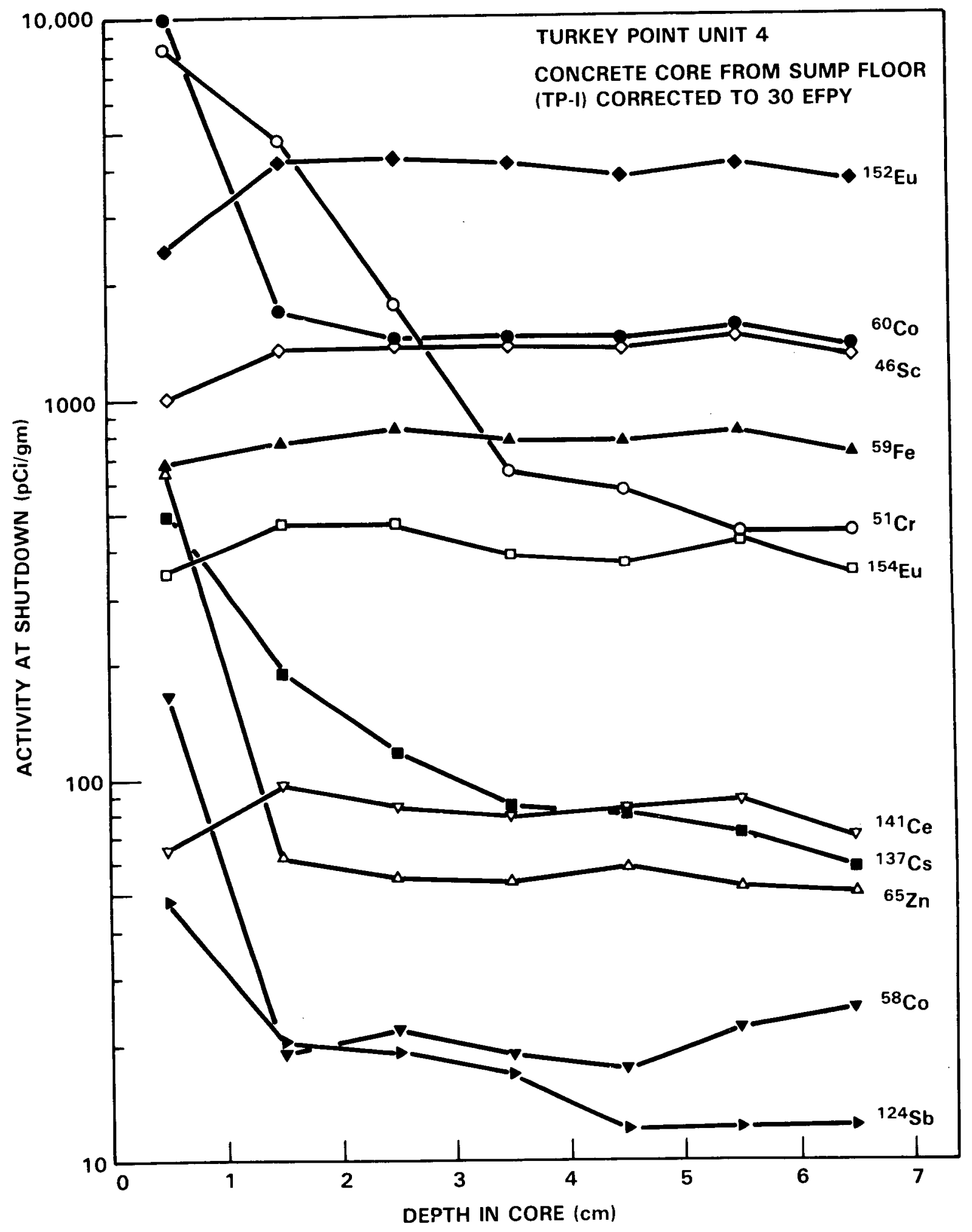

FIGURE 6.2. Depth Profile of Radionuclides in Concrete Core Taken from Sump Floor at Turkey Point No. 4 
TABLE 6.9. Turkey Point Unit 4 Concrete Core TP-I Comparison of Measured and Calculated Activities

\begin{tabular}{|c|c|c|c|}
\hline & $\begin{array}{l}\text { Measured }(a) \\
(\mathrm{pCi} / \mathrm{gm}) \\
\end{array}$ & $\begin{array}{l}\text { Calculated }(b) \\
\quad(\mathrm{pCi} / \mathrm{gm}) \\
\end{array}$ & $\begin{array}{c}\text { Measured } \\
\text { Calculated }\end{array}$ \\
\hline${ }^{46} \mathrm{SC}$ & 1300 & 1000 & 1.3 \\
\hline${ }^{51} \mathrm{Cr}$ & 450 & 570 & 0.8 \\
\hline $54_{M n}$ & $<2$ & 7 & $<0.3$ \\
\hline $55^{\mathrm{Fe}}$ & 18675 & 27900 & 0.7 \\
\hline${ }^{58} \mathrm{Co}$ & 25 & $<3$ & $>8.3$ \\
\hline${ }^{59} \mathrm{Fe}$ & 720 & 780 & 0.9 \\
\hline${ }^{60} \mathrm{Co}$ & 1320 & 1870 & 0.7 \\
\hline${ }^{63} \mathrm{Ni}$ & $<16$ & $<60$ & \\
\hline${ }^{65} \mathrm{Zn}$ & 50 & 130 & 0.4 \\
\hline${ }^{94} \mathrm{Nb}$ & $<2$ & 0.11 & $<18$ \\
\hline $104 m_{A g}$ & $<2$ & $<0.15$ & -- \\
\hline $110 m_{A g}$ & $<5$ & $<28$ & - \\
\hline $124 \mathrm{Sb}$ & 12.5 & 26 & 0.5 \\
\hline${ }^{134} \mathrm{Cs}$ & 58 & 295 & 0.2 \\
\hline${ }^{137} \mathrm{Cs}$ & 133 & 5.7 & 23 \\
\hline${ }^{141} \mathrm{Ce}$ & 54 & 63 & 0.9 \\
\hline${ }^{152} \mathrm{Eu}$ & 3670 & $\equiv 3760$ & $\equiv 1.00$ \\
\hline${ }^{154}{ }_{E u}$ & 350 & 448 & 0.8 \\
\hline${ }^{155_{E u}}$ & $<33$ & 18 & $<1.8$ \\
\hline $166 \mathrm{~m}_{\mathrm{Ho}}$ & $<16$ & -- & -- \\
\hline
\end{tabular}

(a) Activity corrected to reactor shutdown and 30 EFPY. Deepest point in core used.

(b) Calculation based on measured composition of core. PWR flux at $10 \mathrm{~cm}$ depth used. All data normalized to measured ${ }^{152} \mathrm{Eu}$ in core. 


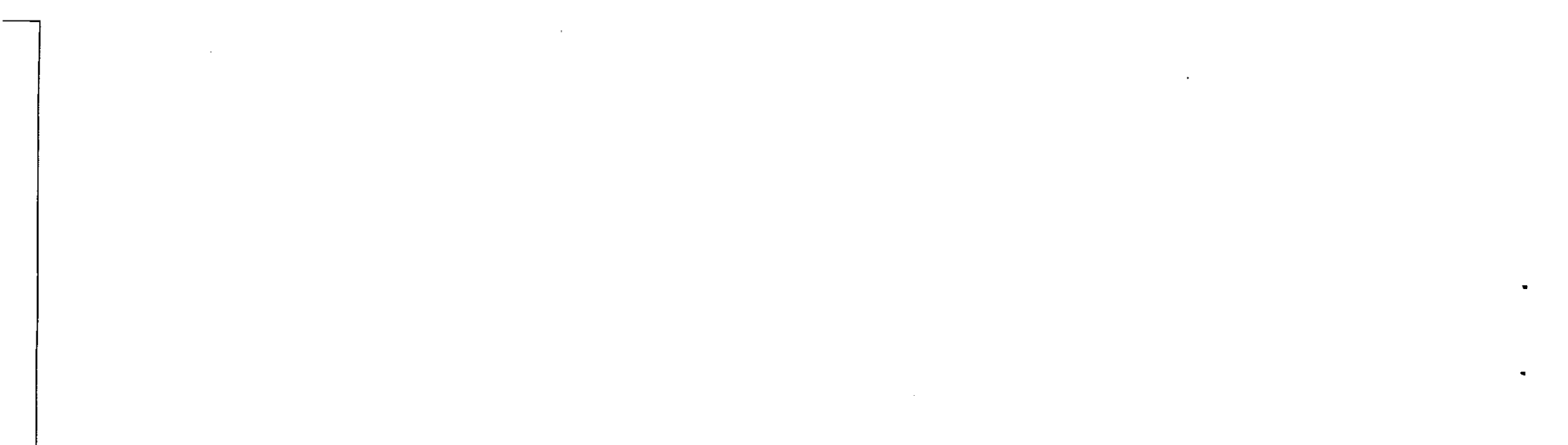




\subsection{EFFECT ON DECOMMISSIONING STRATEGIES}

This program has taken a more detailed look at the question of nuclear activation of reactor construction components. A major goal of the program was to determine if there are any significant reaction pathways and product isotopes which could have a major impact on decomissioning and disposal strategies. It is clear from this work that there should be no real surprises provided relatively ordinary materials have been used for construction. The range of neutron activation expected falls within that considered in the Smith, Konzek, and Kennedy (1978) and Oak et al. (1980) assessments and their conclusions remain valid. Certainly, the decommissioning problem could have been somewhat alleviated by careful selection of materials during construction. Cobalt levels in stainless steel were found to vary in the extreme by more than a factor of ten for example. Selection of materials may not, however, be practical due to the large quantities of steel involved. High cobalt steels are also required in some critical reactor applications due to hardness requirements. 


\subsection{RECOMMENDATIONS FOR FUTURE STUDIES}

It is clear from the assessment done in this study that a good predictive capability exists for determining expected levels of activation products present in light water reactors. Neutron capture cross-sections are reliably available for all important isotopes of interest. The neutron flux distribution is, however, complex particularly within the high flux region and there is a resulting large uncertainty in the calculation of activation levels. Furthermore, activatable trace element levels were found to vary over more than an order of magnitude for several key trace elements including cobalt and niobium. It was not possible within the framework of this program to carry out a full verification of the predictive capability since samples were not, in general, available from the appropriate reactor regions. This type of sampling will only realistically be possible during an actual full scale reactor decommissioning experience. Carefully documented samples should be taken at all points in the decommissioning operation. A sampling plan should in fact be included as part of the predecommissioning planning. For many years to come, each project undertaken will represent a rare opportunity to obtain complete information about the neutron activated components of the reactor system. Sampling should include bioshield cores at several locations, vessel wall sections including cladding, and various samples of reactor internals including control rods. All samples, particularly the internals, should be subsampled onsite to reduce them to a manageable radiation level for analysis. These samples should also be fully documented and archived for future use.

It is important that this be done as part of the dismantling operation in order to take full advantage of the handling facility and decontamination controls in place at that time. Analysis of the samples should include both chemical and radiochemical analysis. This is a rather formidable problem for the highly radioactive components. Energy dispersive, $X$-ray fluorescence analysis was found to be very successful for analyzing even highly radioactive samples. With the addition of wavelength dispersive analysis, a rather complete chemical characterization can be done fully nondestructively. Finally, neutron flux calculations should be carried out for the reactor under study with activity levels predicted in the manner of the present work.

Control rods pose a special problem, since their complex geometries and high neutron opacities render the calculation of activation inventories impractical. A detailed experimental study is suggested. This would involve sectioning the control rods to define production gradients with samples taken for radiochemical analysis. Isotopes analyzed should include ${ }^{55} \mathrm{Fe},{ }^{60} \mathrm{Co}$, ${ }^{59} \mathrm{Ni}$, ${ }^{63} \mathrm{Ni}$, and ${ }^{94} \mathrm{Nb}$ in the cladding. Analys is of PWR control rods should include $110 \mathrm{~m}_{\mathrm{Ag}}$ and $108 \mathrm{~m}_{\mathrm{Ag}}$. BWR control rods should be assayed for ${ }^{14} \mathrm{C}$ and $10_{\mathrm{Be}}$. This program need not be carried out in conjunction with a decomissioning operation, 
since control rods are periodically charged out during routine operations. It will, however, require special handling facilities capable of subsampling highly radioactive materials in complex geometries. 


\subsection{REFERENCES}

AEC-Elk River Reactor Dismantling Plan, SS-836, Rural Cooperative Power Association. 1971.

Atomics International. 1969. Retirement of the Piqua Nuclear Power Facility. AI-AEC-12709.

Bel1, M. J. 1973. "ORIGEN-The ORNL Isotope Generation and Depletion Code." ORNL-4628, Oak Ridge National Laboratory, Oak Ridge, Tennessee.

Bergemann, L., L. Stang, I. Aule, and G. Lorcher. "Neutron Activation of Reactor Pressure Vessel and Biological Shield of the Decommissioned Gundremmingen Unit A Nuclear Power Stations," Proc. 1982 International Decommissioning Symposium, Seattle, October 10-14, 1982, pp. II-59.

Boiling Nuclear Superheater Power Station Decommissioning Final Report, WRA-B-70-500, Prepared by Puerto Rico Water Resources Authority (San Juan, Puerto Rico) and United Nuclear Corporation (Elmford, New York), September 1970.

Browne, E., J. M. Dairiki and R. E. Doebler. 1978. "Table of Isotopes, Seventh Edition," John Wiley and Son, New York.

Calkins, G. D., "Status of Decommissioning Rrogram of U.S. Nuclear Regulatory Commission," Proc. 1982 International Decommissioning Symposium, Seattle, 0ct. 10-14, 1982. pp. II-21.

Engle, W. E., Jr. "A Users Manual for ANISN, A One Dimensional Discrete Ordinates Transport Code with Anisotropic Scattering." K-1693, Oak Ridge National Laboratory, Oak Ridge, Tennessee, March 1967.

Flanagan, F. J. 1973. "1972 Values for International Geochemical Reference Samples." Geochimica et Cosmochimica Acta (37), pp. 1189-1200.

Gladney, E. S. 1980a. "Compilation of Elemental Concentration Data for NBS Biological and Environmental Standard Reference Materials," LA-8438-MS.

Gladney, E. S. 1980b. "Compilation of Elemental Concentration Data for United States Geological Survey's Eight New Rock Standards," LA-8265-MS.

Gritzner, M. L., G. L. Simmons, T. E. Albert and E. A. Strake. 1977. "PWR and BWR Radiation Environments for Radiation Damage Studies," EPRI NP-152. 
Hallam Nuclear Power Facility, Entombment. Report on Retirement of Hallam Nuclear Power Facility, AI-AEC-12709, May 1970.

ICRP. 1959. Report of Committee II.

International Atomic Energy Agency. 1978. Report on the Intercomparison Run Soil-5 for the Determination of Trace Elements in Soil, by Rajmund Dybczynski, Aysen Tugsavul and Otto Suschny, IAEA Laboratory Seibersdorf, IAEA/RL/46.

Kittinger, W. D., B. F. Ureda, C. C. Conners. "Lessons Learned in Decommissioning the Sodium Reactor Experiment." Proc. 1982 International Decommissioning Symposium, Seattle, Oct. 10-14, 1982, pp. IV-1.

Laul, J. C., C. L. Wilkerson, and V. L. Crowe. "Computer Methodology and Its Applications to Geological and Environmental Matrices," Proc. Am. Nucl. Soc. Topic Conf at Mayaguez, Puerto Rico, April 30- May 3, 1978.

Laul, J. C., "Neutron Activation Analysis of Geological Materials, Atomic Energy Review 17, p. 603-694, 1979.

Manion, W. J. and T. S. LaGuardia. 1980. "Decommissioning Handbook," DOE/EV-10128-1.

Mason, B. 1966. "Principles of Geochemistry," Third Edition, John Wiley and Sons, p. 45.

Mughabghab, M. Divadeenam and N. E. Holden. 1981. "Neutron Cross-Sections, Volume 1, Neutron Resonance Parameters and Thermal Cross-Section, Part $A: Z=1-60$," Academic Press, New York.

National Bureau of Standards. 1969. Certificate of Analysis, Standard Reference Material 1155, Stainless Steel, $\mathrm{Cr}$ 18-Ni 12-Mo 2 (AISI 316).

National Bureau of Standards. 1971. Certificate of Analysis, Standard Reference Material 123c, Stainless Steel, $\mathrm{Cr}$ 17-Ni 11-Nb 0.6 (AISI 316).

Nielson, K. K. and R. W. Sanders. 1982. "The SAP3 Computer Program for Quantitative Multielement Analysis by Energy Dispersive X-ray Fluorescence," Pacific Northwest Laboratory Report to U.S. Department of Energy, PNL-4173.

Nielson, K. K., R. W. Sanders, and J. L. Evans. 1982. "Analysis of Steels by Energy Dispersive $X$-ray Fluorescence with Fundamental Parameters," J. Anal. Chem., 54, 1782-1786. 
Oak, H. D., G. M. Holter, W. E. Kennedy, Jr. and G. J. Konzek. 1980.

"Technology, Safety, and Costs of Decommissioning a Reference Boiling Water Reactor Power Station," NUREG/CR-0672.

Pearlstein, S. 1975. Program THRES2, National Neutron Cross-Section Center, Brookhaven National Laboratory, Upton, New York. See also Pearlstein, S., "Neutron Induced Reactions in Medium Mass Nuclei," JNE 27 (1973) 81-99.

Smith, R. I., G. J. Konzek and W. E. Kennedy, Jr. 1978. "Technology, Safety, and Costs of Decommissioning a Reference Pressurized Water Reactor Station," NUREG/CR-0130.

Stevens, J. J., Jr. and R. D. Poh1. 1977. "Trace Elements in Reactor Steels: Implications for Decommissioning," Report 2882, Laboratory of Atomic and Solid State Physics and Material Science Center, Cornell University.

United Power Association, "Final Elk River Reactor Program Report," (00-651-93, November 1974).

U.S. Department of Energy, Nuclear Reactors Built, Being Built, or Planned in the United States as of June 30, 1981, IC-8200-R44, December 1981.

Walker, F.W., G. J. Kirovac, and F. M. Rourke. 1977. "Chart of the Nuclides, Twelfth Edition," General Electric Company.

Wogman, N. A., D. P. Brown, H. G. Rieck, and J. C. Laul. "Computer Controlled Cyclic Activation Analysis with ${ }^{252} \mathrm{Cf}$ - $235 \mathrm{U}$ Subcritical Multiplier, "Proc. of Am. Nuclear Soc. Topical Conf at Mayaguez, Puerto Rico, April 30- May 1978, PNL-SA-6861.

Woolam, P. B. 1978a. "The Radioactive Inventory of a Decommissioned Magnox Power Station Structure. 1. Measurements of Neutron Induced Activity in Samples from the Reactor Island," RD/B/N4231, DECOM78/3 (Revised).

Woolam, P. B. 1978b. "An Assessment of the Data for Decommissioning, Calculations on Ag-108 Metastable." RD/B/N 4373, DEC0M78/6, CNDC/(78)P10.

Woolam, P. B. and I. G. Pugh. 1978. "The Radioactive Inventory of a Decommissioned Magnox Power Station Structure. 2. A Summary of Neutron Induced Activation, Waste Disposal and Dose Equivalent Rates for the Reactor Island Structure," RD/B/R4350, NP/234, DECOM78/5 (Revised). 


\section{GENERAL INFORMATION}

A group of computer programs was written to calculate expected production rates of long-lived activation products on an isotope by isotope basis. A description of the calculation method is given in Section 5.1. The code is highly interactive, simple to use, and runs on widely available minicomputers. It would be suitable for use by utilities for developing procedures for compliance with 10 CFR 61. A simplified version, including only those isotopes of major importance, would be most useful in that context since many of the isotopes considered here are of negligible importance and are in any case not covered by the regulatory guidelines.

The computer code is written in FORTRAN IV. It is designed for the DEC family of computers, but could easily be adapted to many other systems with minor changes in file management. All of the programs are run interactively with results written to a file, rather than directly to a printer. All of the data generated in this report were run on a VAX 11/780, although the programs were originally developed on a PDP 11/34 using an RSX 11/M operating system with only $32 \mathrm{~K}$ of memory available for the program. No overlaying was used. Conversion to the VAX was trivial with computing speed greatly improved. This extra speed proved useful, though not essential. The iterative method used in the calculation, while requiring very little memory, is time consuming. The following programs were used:

NUCLIB - interactively creates the nuclear data libraries. Five different types of libraries can be formed including $\mathrm{N}$-gamma only, $\mathrm{N}-2 \mathrm{~N}, \mathrm{~N}-\mathrm{P}, \mathrm{N}-\mathrm{D}$, and $\mathrm{N}-\mathrm{a}$ lpha.

DATDMP - used to list a nuclear data library of interest. It uses a single subroutine, DATBAS, for most of the formatting and writes the results in an easily readable form on a file named PRINT.LIB.

COMPOS - used to create composition files for each material type of interest. Fifty-three elements are included. The file ELEMENT.DAT is used as the basic template. It contains the element names, atomic. numbers and atomic weights. The name of the composition file for output is specified interactively at program initiation. 
FLUX1 - used to create a file of neutron flux information and reactor conditions including thermal flux, epithermal flux, fast flux in

$0.5 \mathrm{MeV}$ increments from 0.5 to $15 \mathrm{MeV}$, and reactor temperature. The name of the flux file is specified interactively by the operator at program initiation. An easily readable reformatted version is also automatically written to a file called PRINT.FLX, which can be hard copied as a permanent record. FLXDMP can also be used to list the flux file. It is output on PRINT.FLX.

ACTIV - used for the actual activation calculation using the nuclear data libraries, the composition and flux files and five batch files containing the isotope names for use with each library. Subroutines used include NCAP, DMP, FINAL, and COMBAS. The batch files are created and named using the system editor. The results are written on a file named PRINT.ACT.

Hard copy results from any of the above are obtained simply by using the appropriate system COPY commands.

\section{CODE USE}

NUCLIB

The program will first ask "File for nuclear data library?." This will be the output file and must be a legal DEC file name plus extension. For input into ACTIV, the file name must be one of the following:

$\begin{array}{ll}\text { NUCLIB } \emptyset . L I B & \mathrm{~N}-\text { gamma only } \\ \text { NUCLIB1.LIB } & \mathrm{N}-2 \mathrm{~N} \\ \text { NUCLIB2.LIB } & \mathrm{N}-\mathrm{P} \\ \text { NUCLIB3.LIB } & \mathrm{N}-\mathrm{D} \\ \text { NUCLIB4.LIB } & \mathrm{N}-\mathrm{a} \text { ipha. }\end{array}$

A different file name can be used initially and renamed or concatenated with a larger piece of the file later. Ultimately, there should only be one version of each on the disk to avoid losing the main libraries during general file purges. The program will next ask for the reaction type with a menu of choices displayed. All entries in that particular library will then be assigned that reaction type automatically. Next, the product element and isotope mass will be requested. The isotope mass is read as an 13 format, so it is necessary to include a leading zero or blank for two digit entries. It will then request the number of elements in the chain. This allows for multiple neutron capture and beta decay considerations. This allows considerable flexibility in assembling the library. Some judgment is required based on an examination of 
the chart of the nuclides and the available data. For $\mathrm{N}-\gamma$ or $\mathrm{N}-2 \mathrm{~N}$ reactions, in most cases, a single element is all that is required. For charge particle reactions, such as $N-P$, at least two elements are needed. The program can handle up to nine elements in a chain. The atomic number ( $Z$ ) of the product element is requested. The program will then request the number of isotopes at the $Z$ corresponding to the first element in the chain, and the mass of that isotope. It will then step its way up the chain asking at each point for isotopic abundance, fission yield, half-life, production cross section, production resonance integral, depletion cross section, and depletion resonance integral. This process will continue for each isotope in the chain. In most cases, a simple carriage return (i.e., no data) will insert a zero. For the half-life, a carriage return sets the half-life to $1 E 31$ years, a computational approximation to infinity. This is intended for stable isotopes, and is a somewhat whimsical choice based on the limits on the nucleon lifetime set by a number of proton decay experiments recently. A carriage return for a resonance integral will set it equal to 0.45 times the thermal cross section. That is simply the $1 / V$ value with no resonances and, as such, is the theoretical minimum. Following all of the above entries, the program will then request entries for the high energy excitation function. For the $\mathrm{N}$-gamma only library (reaction type 0 ), that step is omitted and it loops directly back to the start. A new isotopic entry can be started or a control $Z$ entered to close the file and exit the program. In its present form, ACTIV requires that all five library types exist since it automatically steps through them. This could easily be modified.

Some ingenuity is needed in constructing the libraries. For example, if one wishes to cross compare relative yields by direct neutron capture and $\mathrm{N}-2 \mathrm{~N}$, the same isotope can be placed in both libraries with the direct capture cross sections set to zero in the $\mathrm{N}-2 \mathrm{~N}$ library. Tritium and carbon-14 are computed in the $\mathrm{N}-\mathrm{r}$ only library because the cross-section data is typically available in that form. Tritium, for example, is simply entered into the library like an $\mathrm{N}-\mathrm{Y}$ reaction on lithium. A listing of the program follows.

DATDMP

This program produces a listing of any of the nuclear data libraries in a conveniently readable format. It simply requests the file name and produces the result on PRINT.LIB for later inspection or hard copy. A listing of the program and the subroutine DATBAS follows.

COMPOS

This is used to create a composition file for 53 elements. The file ELEMENT.DAT is used to provide element names, atomic numbers, and atomic weights. The program first requests the sample type. This can be up to 
72 characters. The file name is requested. This should be in some conveniently identifiable format (i.e., for type 304 stainless steel, a file name SS304.CMP would be appropriate). The program then steps through the elements in sequence displaying each on the screen and requesting its concentration in parts per million. A carriage return will enter a zero and flag it as not measured. An entry will be followed by a request asking whether it is an upper limit ( $Y$ or $N$ ). Some radioactive elements, such as plutonium, are included since the output file is also used by ACTIV to provide atomic weights. A listing of COMPOS and ELEMENT.DAT follows.

FLUX1

This program creates a a file for a specific set of reactor conditions. It first requests a file name for the output file. A.FLX extension is useful for keeping track of file types. The thermal flux, epithermal flux, and fast flux in 29 groups from 0.5 to $15 \mathrm{MeV}$ are then requested. The temperature is requested followed by a request for reactor conditions. The latter is simply an up to 72 character description of the conditions represented by the fluxes used. A reformatted copy of the data is automatically output to PRINT.FLX. A listing of FLUX1 follows.

FLXDMP

This is an alternative method for listing a flux file in a conveniently readable format. The program simply requests the file name and lists the results on PRINT.FLX. A listing of the program and some sample output follow.

Batch Run Files

Five batch run files are required to provide the names of isotopes to be calculated by the five libraries. They are paired as follows:

BATCHO.LIB - NUCLIBO.LIB

BATCH1.LIB - NUCLIB1.LIB

BATCH2.LIB - NUCLIB2.LIB

BATCH3.LIB - NUCLIB3.LIB

BATCH4.LIB - NUCLIB4.LIB.

The isotope names given in the batch files must match the isotopes entered into the appropriate library. ACTIV will automatically search the NUCLIBO.LIB file for each isotope listed in BATCHO.LIB, etc. If the isotope is not present, a warning will appear on the screen, and it will continue with the next isotope. The files are created using the standard DEC EDITOR. There are no blanks proceeding the element name and it must be spelled correctly. The isotope mass must be in an I3 format with the correct number of leading blanks or zeros. An 
APPENDIX A

CODE DESCRIPTION 
example of the five batch files follows. Please note that the file name is included only for information. It should not actually be imbedded in the file.

$\underline{\text { ACTIV }}$

The activation calculation is carried out by a numerical integration method using the files created by NUCLIB, COMPOS, and FLUX1 together with a batch file created by the EDITOR specifying which isotopes to compute. The main program uses repeated calls to subroutine NCAP to determine incremental changes in the number of atoms of each isotope in the chain. Subroutine DMP is used for printing results in 1-year increments. FINAL keeps track of the run time for each isotope and COMBAS produces a listing of the composition file at the end. The program first request the name of the composition file and opens that file. The sample type is read and printed on the screen. It then opens an output file. Results will appear on PRINT.ACT. Next, the name of the flux file is requested, the file opened, and the data read. No further operator input is needed. The program will open the five-batch run files in sequence and compute the results for each isotope. Results are written to file PRINT.ACT. As each isotope is finished, a message will appear on the screen giving the time consumed for that isotope. This is useful for benchmarking and, on slower machines, keeping track of the progress of the calculation. After all computing is done, a listing of the composition file is made on PRINT.ACT, all files closed, and execution terminated. Listings of the ACTIV, NCAP, DMP, FINAL, and COMBAS are found in Appendix $B$. 
C

C

$\mathrm{C}$

C

C

$\mathrm{C}$

INTEGER $\mathrm{Z}, \mathrm{ZZ}$

TYPE 51

51 FORMAT( $1 X, ' F I L E$ FOR NUCLEAR DATA LIBRARY')

$\operatorname{READ}(5,52, E R R=1100) \mathrm{FILE} 4$

52 FORMAT (5A4)

CALL ASSIGN (1,FILE4)

1102 TYPE 40

40 FORMAT (1X, 'REACTION TYPE?')

TYPE 41

41 FORMAT ( $1 X,{ }^{\prime} 0=N-G A M M A$ ONLY')

TYPE 42

42 FORMAT ( $\left.1 X, ' 1=N-2 N^{\prime}\right)$

TYPE 43

43 FORMAT ( $\left.1 \mathrm{X},{ }^{\prime} 2=\mathrm{N}-\mathrm{P}^{\prime}\right)$

TYPE 44

44 FORMAT $\left(1 X, ' 3=N-D^{\prime}\right)$

TYPE 45

45 FORMAT ( $1 \mathrm{X},{ }^{\prime} 4=\mathrm{N}-\mathrm{ALPHA}$ ')

$\operatorname{READ}(5,7, E R R=1102)$ ITYPE

400 TYPE 1

1 FORMAT( $1 X, '$ PRODUCT ELEMENT (CONTROL Z TO TERMINATE)?')

$\operatorname{READ}(5,2, \operatorname{END}=999, \mathrm{ERR}=400) \mathrm{ELNAME}$

2 FORMAT ( $3 A 4$ )

1101 TYPE 3

3 FORMAT(IX,' ISOTOPE MASS?')

$\operatorname{READ}(5,4, \operatorname{ERR}=1101) \mathrm{M}$

4 FORMAT (I3)

WRITE $(1,5)$ ELNAME, M, ITYPE

5 FORMAT (IX, 3A4, I3, 10X, II)

1103 TYPE 6

6

7

1104

60

70

WRITE $(1,8) \mathrm{N}, \mathrm{Z}$

8 FORMAT (IX, II , I0X, I2)

DO $100 \quad I=1, N$

$\mathrm{ZZ}=\mathrm{Z}-\mathrm{N}+\mathrm{I}$

1105 TYPE $9,2 \mathrm{Z}$ 


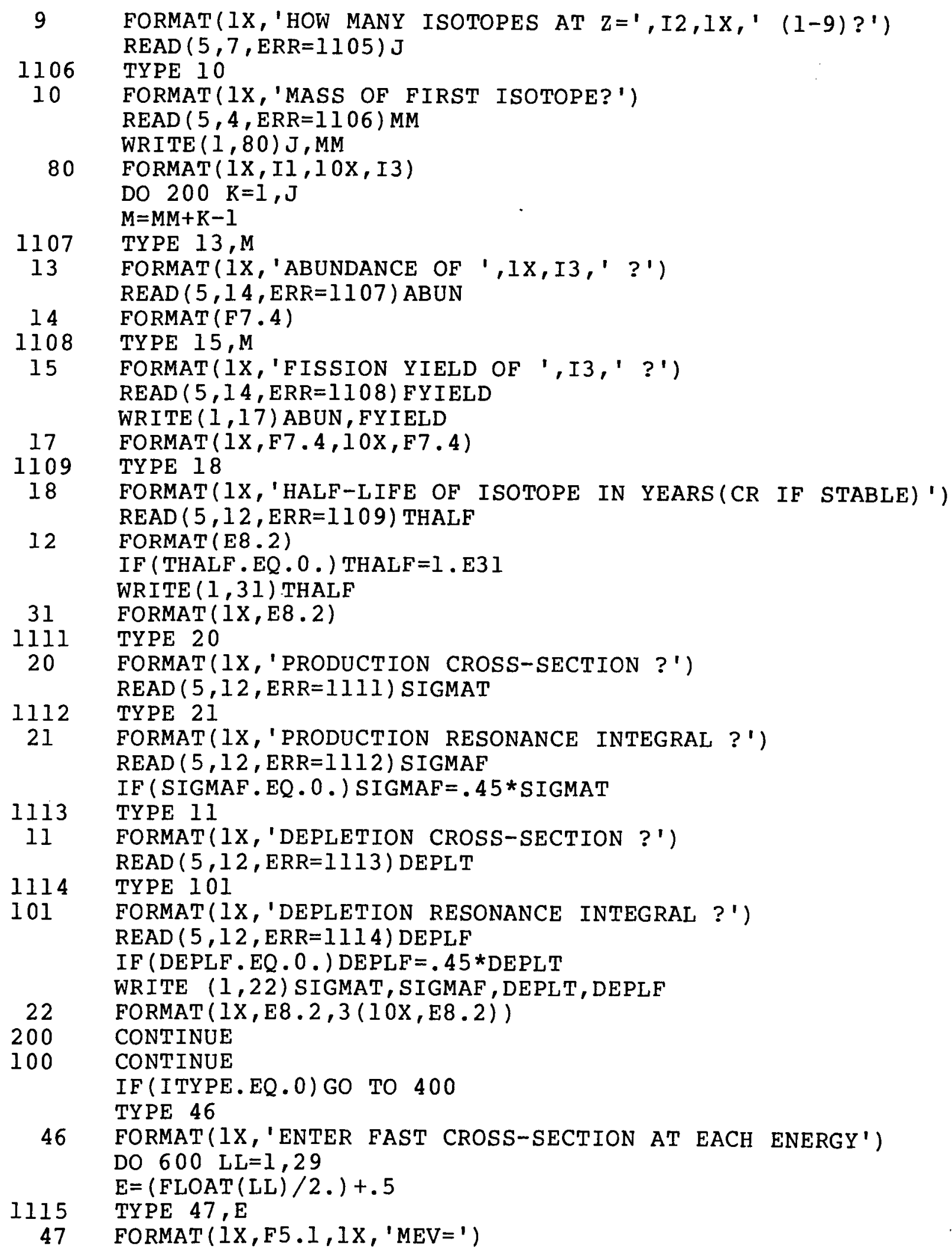




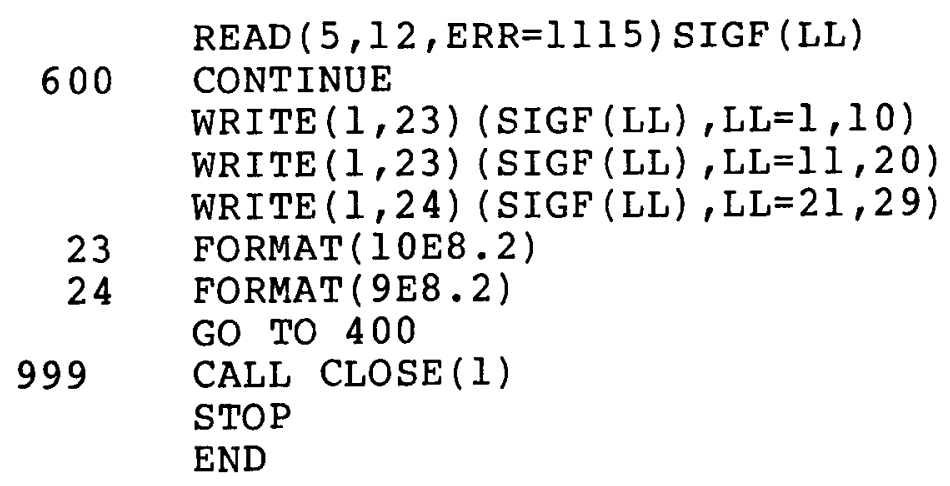




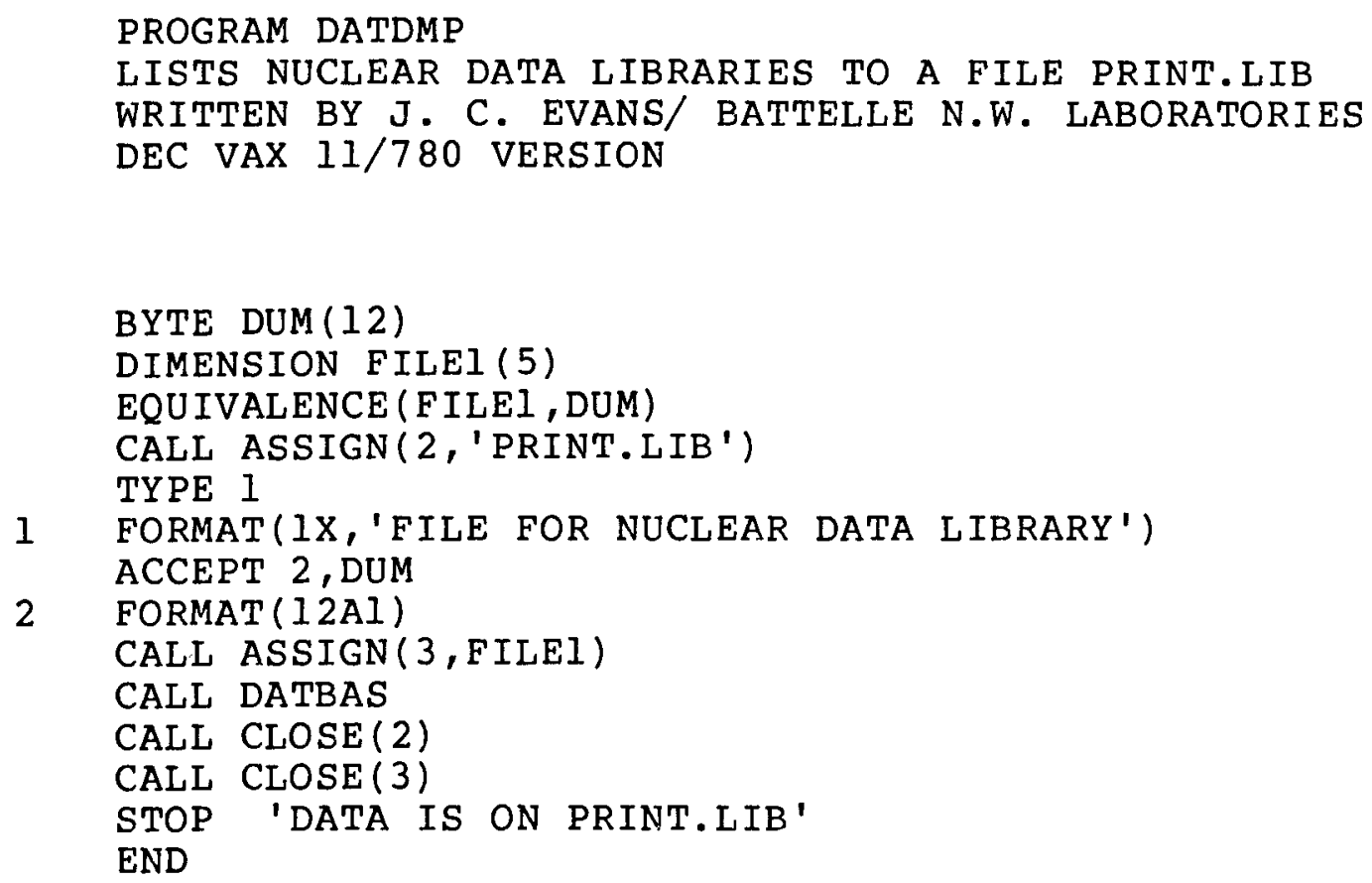




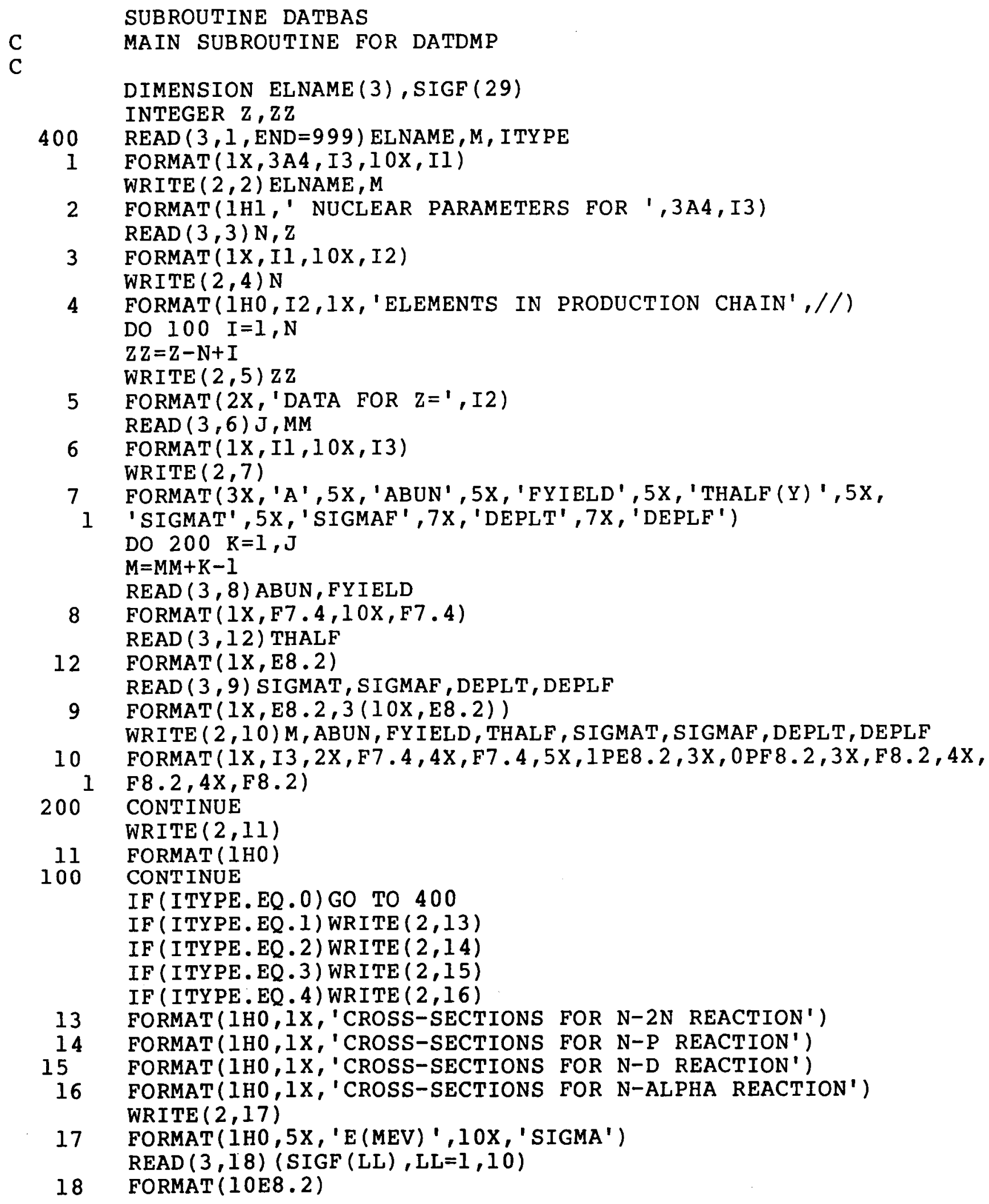




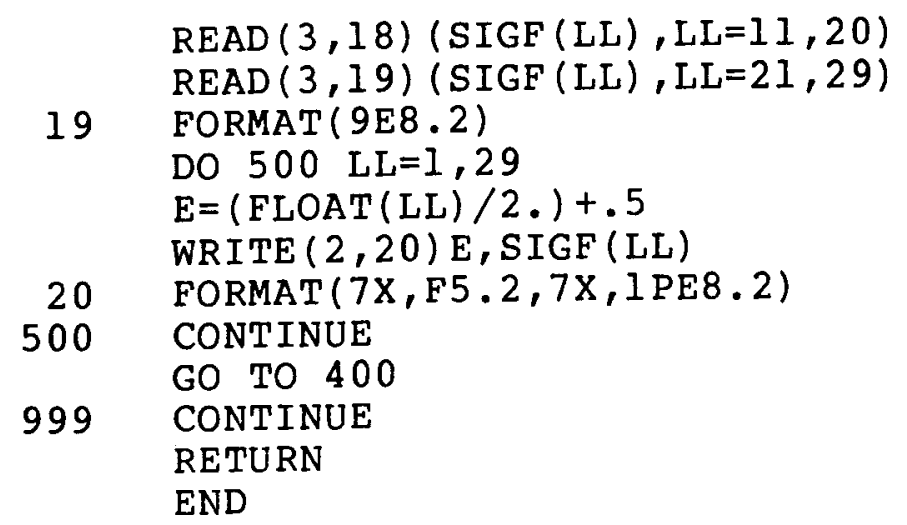




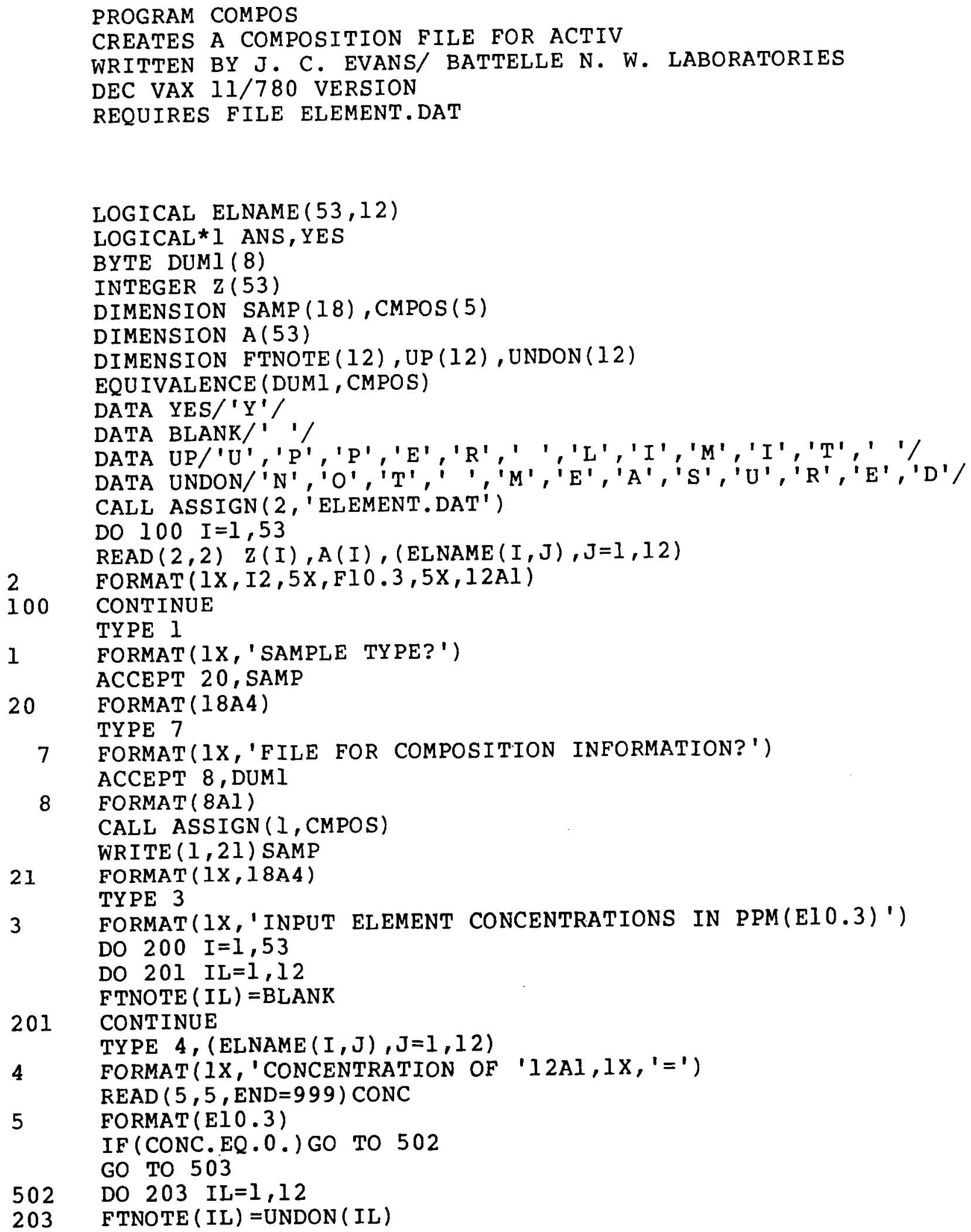




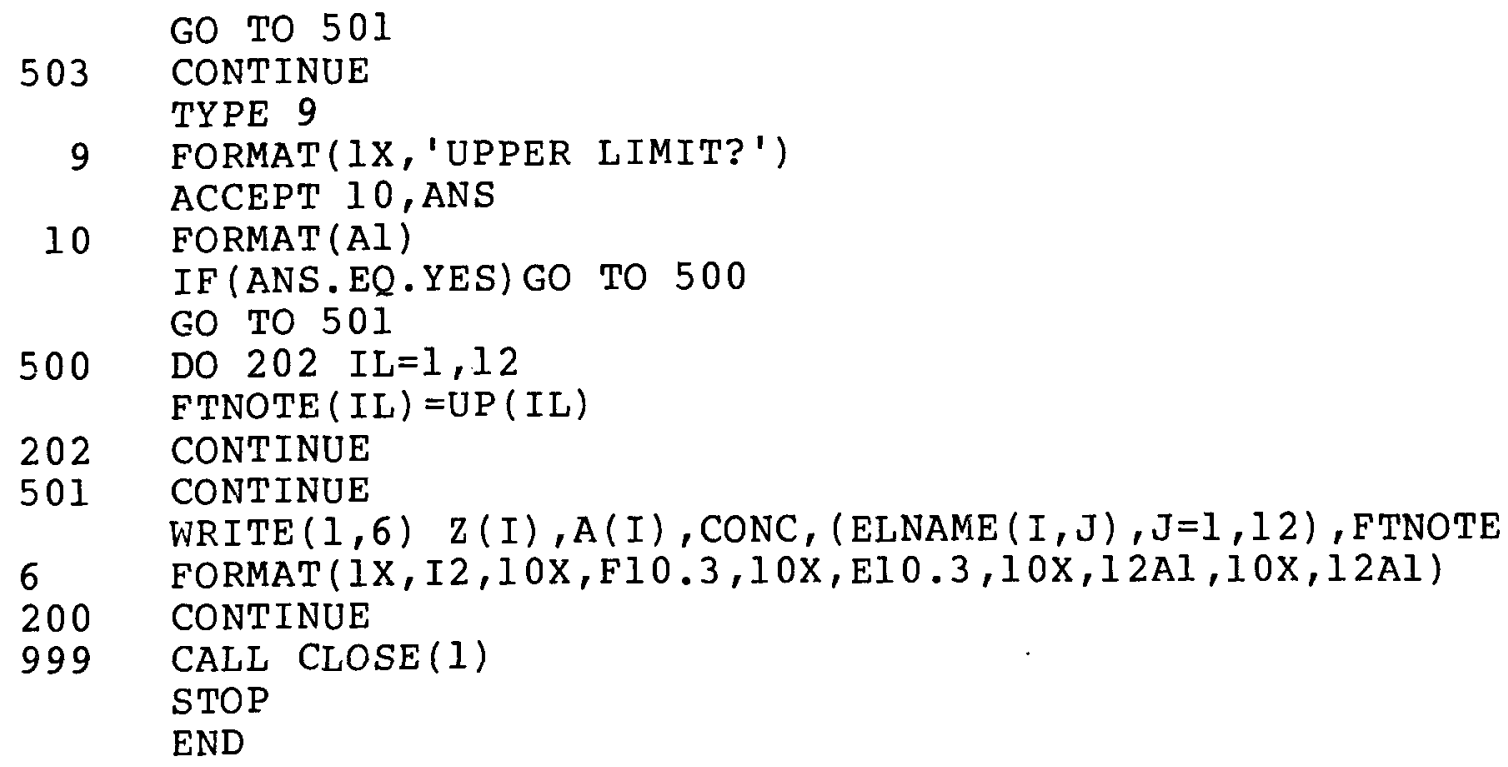




$\begin{array}{lll}1 & 1.008 & \text { HYDROGEN } \\ 3 & 6.94 & \text { LITHIUM } \\ 5 & 10.811 & \text { BORON } \\ 7 & 14.0067 & \text { NITROGEN } \\ 11 & 22.99 & \text { SODIUM } \\ 13 & 26.982 & \text { ALUMINUM } \\ 16 & 32.064 & \text { SULFUR } \\ 17 & 35.453 & \text { CHLORINE } \\ 18 & 39.948 & \text { ARGON } \\ 19 & 39.102 & \text { POTASSIUM } \\ 20 & 40.08 & \text { CALCIUM } \\ 25 & 54.938 & \text { MANGANESE } \\ 26 & 55.847 & \text { IRON } \\ 27 & 58.9332 & \text { COBALT } \\ 28 & 58.71 & \text { NICKEL } \\ 29 & 63.54 & \text { COPPER } \\ 30 & 65.35 & \text { ZINC } \\ 33 & 74.93 & \text { ARSENIC } \\ 34 & 78.96 & \text { SELENIUM } \\ 35 & 79.904 & \text { BROMINE } \\ 36 & 83.80 & \text { KRYPTON } \\ 37 & 85.468 & \text { RUBIDIUM } \\ 38 & 87.62 & \text { STRONTIUM } \\ 39 & 88.905 & \text { YTTRIUM } \\ 40 & 91.22 & \text { ZIROONIUM } \\ 41 & 92.906 & \text { NIOBIUM } \\ 42 & 95.94 & \text { MOLYBDENUM } \\ 43 & 99 . & \text { TECHNETIUM } \\ 46 & 106.4 & \text { PALLADIUM } \\ 47 & 107.87 & \text { SILVER } \\ 50 & 118.69 & \text { TIN } \\ 51 & 121.75 & \text { ANTIMONY } \\ 53 & 126.9045 & \text { IODINE } \\ 55 & 132.905 & \text { CESIUM } \\ 56 & 137.33 & \text { BARIUM } \\ 62 & 150.35 & \text { SAMARIUM } \\ 63 & 151.96 & \text { EUROPIUM } \\ 65 & 158.924 & \text { TERBIUM } \\ 66 & 162.50 & \text { DYSPROSIUM } \\ 67 & 164.93 & \text { HOLMIUM } \\ 71 & 174.97 & \text { LUTETIUM } \\ 72 & 178.49 & \text { HAFNIUM } \\ 74 & 183.85 & \text { TUNGSTEN } \\ 75 & 186.2 & \text { RHENIUM } \\ 76 & 190.2 & \text { OSMIUM } \\ 77 & 192.2 & \text { IRRIDIUM } \\ 82 & 207.200 & \text { LEAD } \\ 83 & 208.98 & \text { BISMUTH } \\ 90 & 232.038 & \text { THORIUM } \\ 91 & 233 . & \text { PROTOACTINIUM } \\ 92 & 238.03 & \text { URANIUM } \\ 93 & 239 . & \text { NEPTUNIUM } \\ 94 & 239 . & \text { PLUTONIUM } \\ & & \end{array}$

\section{B. 9}




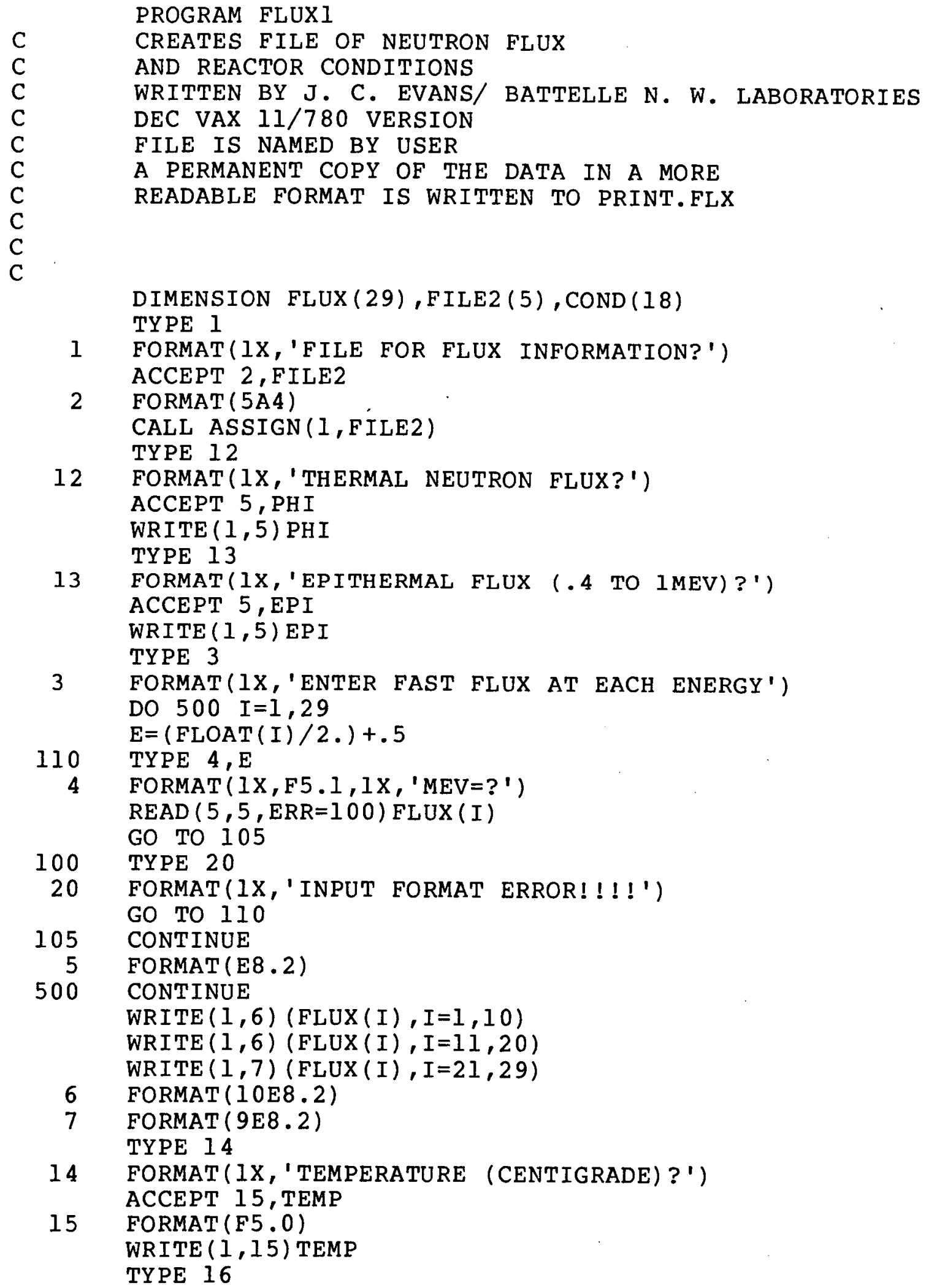


16 FORMAT( $1 \mathrm{X}$, 'REACTOR CONDITIONS')

ACCEPT 17, COND

17 FORMAT (18A4)

$\operatorname{WRITE}(1,17)$ COND

CALL CLOSE (I)

CALL ASSIGN ( 1 , 'PRINT. FLX')

WRITE $(1,8)$ FILE2

8 FORMAT(5X,' 'FAST FLUX DATA FOR FILE ',5A4)

$\operatorname{WRITE}(1,9)$

9 FORMAT(5X,'FLUX DATA IN UNITS OF NEUTRONS/CM2*SEC*MEV',/) WRITE $(1,10)$

10 FORMAT ( 1 HO , 4X, 'ENERGY (MEV) ' $10 \mathrm{X}$, 'FLUX', /)

DO $600 \quad I=1,29$

$E=(F L O A T(I) / 2)+$.

WRITE $(I, I I)$ E, FLUX (I)

11 FORMAT ( $11 \mathrm{X}, \mathrm{F} 5.2,6 \mathrm{X}, 1 \mathrm{PE} 8.2$ )

600 CONTINUE

STOP

END 


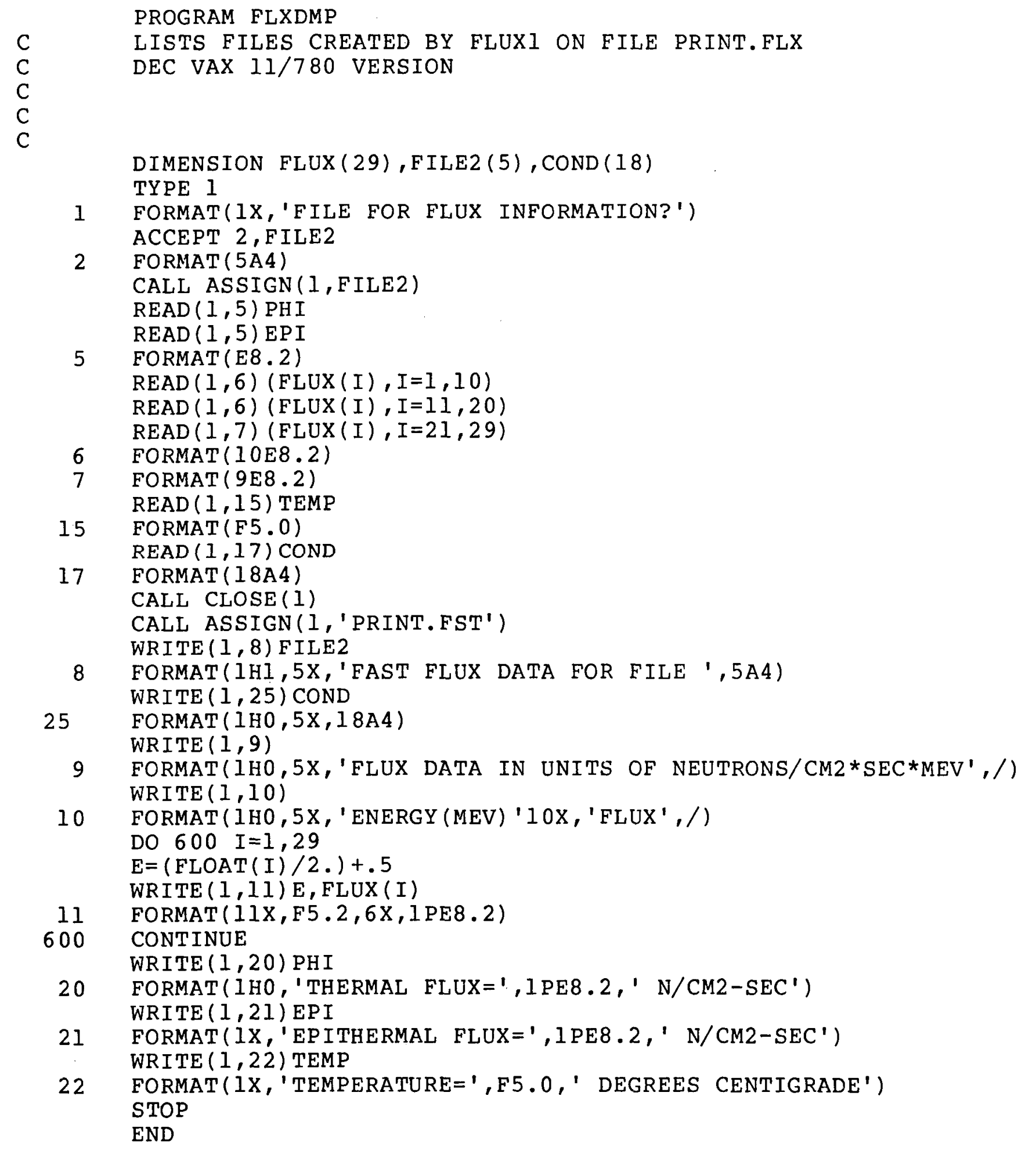


$\star \star \star \star$ BATCHO .LIB $* * \star *$

TRITIUM

3

CARBON

14

COBALT

60

NICKEL

63

KRYPTON

81

STRONTIUM

90

TECHNITIUM

99

SILVER

110

SAMARIUM

151

EUROPIUM

152

EUROPIUM

154

EUROPIUM

155

HOLM IUM

166

HAFNIUM

178

URAN IUM

233

URAN IUM

236

PLUTONIUM

239 


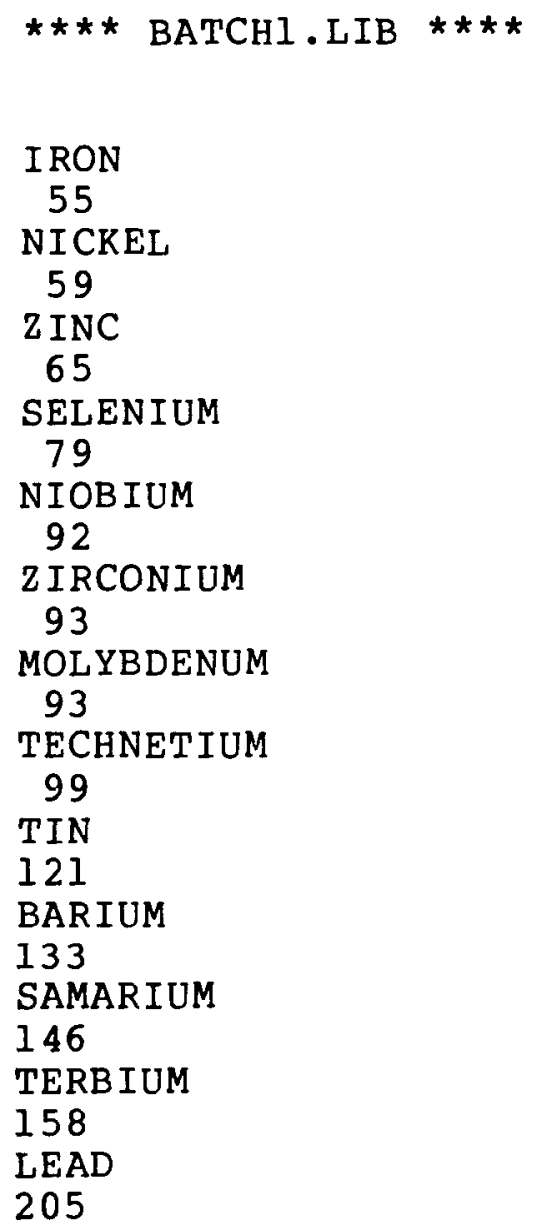


ARGON

39

MANGANESE

54

NICKEL

63

KRYPTON

85

NIOB IUM

92

ZIRCONIUM

93

PALLADIUM

107

TIN

121

CESIUM

134

CESIUM

135

CESIUM

127

EUROPIUM

155

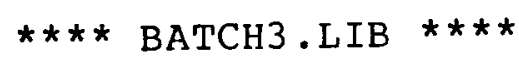

MANGANESE

53

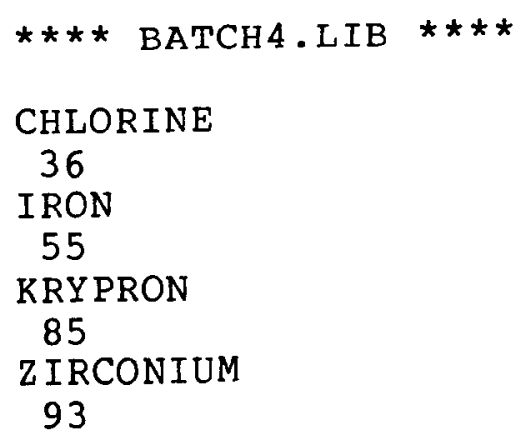




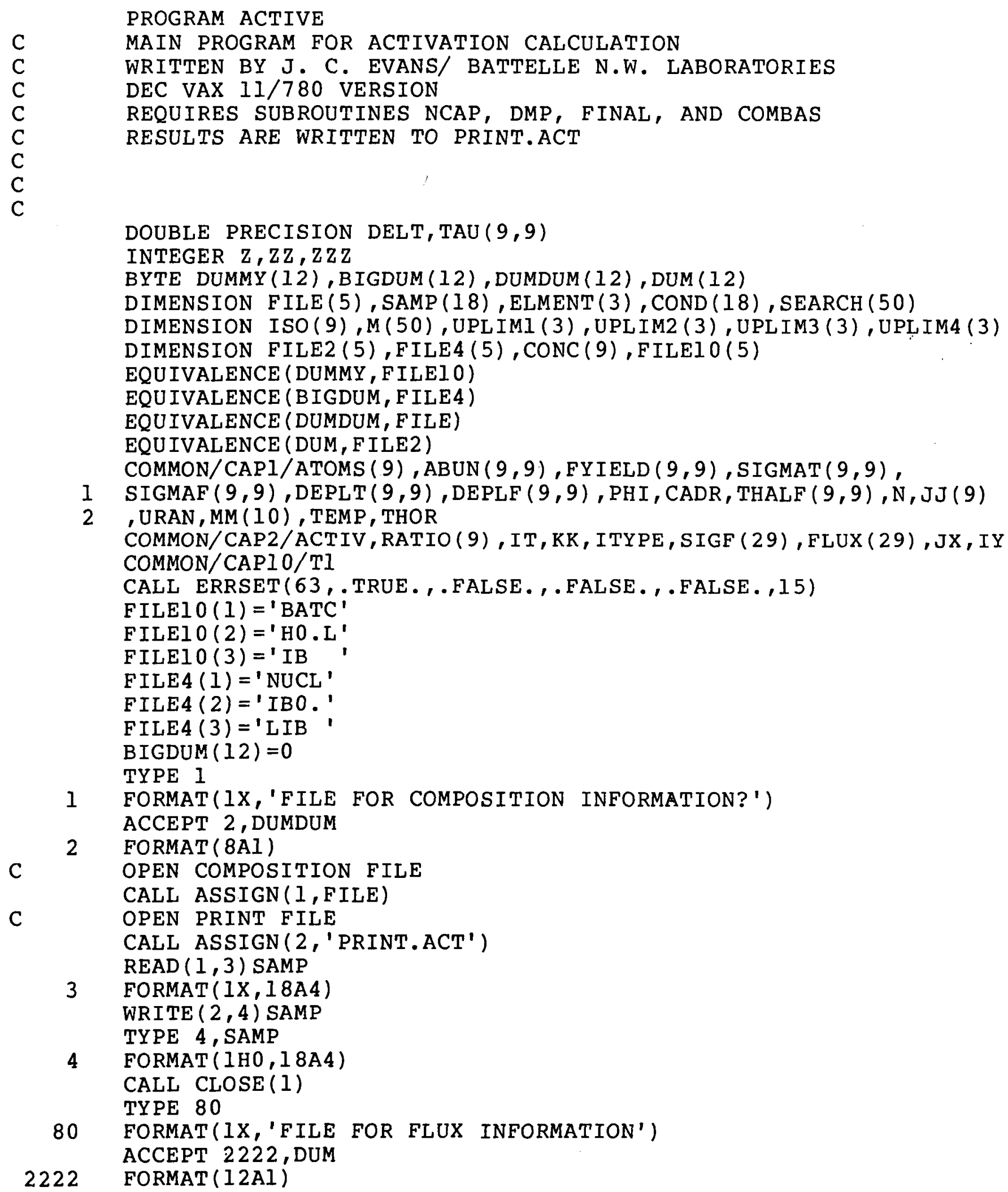


CALL ASSIGN (3,FILE2)

C INPUT THERMAL FLUX

$\operatorname{READ}(3,6)$ PHI

6 FORMAT (E8.2)

WRITE $(2,7)$ PHI

7 FORMAT ( 1 HO, 'THERMAL NEUTRON FLUX =' $1 \mathrm{X}, 1 \mathrm{PE} 8.2,1 \mathrm{X}$, 'N/CM2 * SEC')

C INPUT EPITHERMAL FLUX

$\operatorname{READ}(3,6) \operatorname{EPI}$

C CONVERT TO FLUX PER UNIT LETHARGY

$E P I U=E P I / I 4.27$

C COMPUTE CADMIUM RATIO

CADR=PHI/EPIU
C INPUT FAST FLUX

$\operatorname{READ}(3,81)(\operatorname{FLUX}(L L), L L=1,10)$

$\operatorname{READ}(3,81)(\operatorname{FLUX}(L L), L L=11,20)$

$\operatorname{READ}(3,82)(\operatorname{FLUX}(L L), L L=21,29)$

81 FORMAT (10E8.2)

82 FORMAT (9E8.2)

C INPUT TEMPERATURE

$\operatorname{READ}(3,33)$ TEMP

33 FORMAT (F5.0)

WRITE $(2,10)$ CADR, TEMP

10 FORMAT(1H,' CADMIUM RATIO=',F8.2,10X,' TEMPERATURE=' ,F5.0,1X,

1 'DEGREES CENTIGRADE')

$\operatorname{READ}(3,19)$ COND

CALL CLOSE ( 3 )

19 FORMAT (18A4)

WRITE $(2,20)$ COND

20 FORMAT(1H0, 18A4)

$T 1=S E C N D S(0$.

C

OPEN BATCH RUN FILE

DO 500 IJK $=1,5$

$I=I$

IF (IJK.EQ.1) DUMMY (6) =' 0 '

$\operatorname{IF}($ IJK.EQ.1) BIGDUM (7) $=$ ' 0 '

IF (IJK.EQ . 2) DUMMY ( 6$)=11$ '

IF (IJK.EQ.2) BIGDUM(7) $=' 1$ '

IF (IJK.EQ.3) DUMMY (6) =' 2 '

$\operatorname{IF}($ IJK.EQ.3) BIGDUM (7) $=$ ' 2 '

IF (IJK.EQ.4) DUMMY $(6)=13$ '

$\operatorname{IF}(I J K . E Q .4) \operatorname{BIGDUM}(7)=13$ '

IF (IJK.EQ.5) DUMMY $(6)=' 4$ '

IF (IJK.EQ . 5) BIGDUM (7) $={ }^{\prime} 4^{\prime}$

100 CONTINUE

CALL ASSIGN $(4$, FILEI0)

$\operatorname{READ}(4,42, \operatorname{END}=110) \operatorname{SEARCH}(I)$

42 FORMAT (A4)

$\operatorname{READ}(4,14) M(I)$

14 FORMAT (I3)

$I=I+1$ 


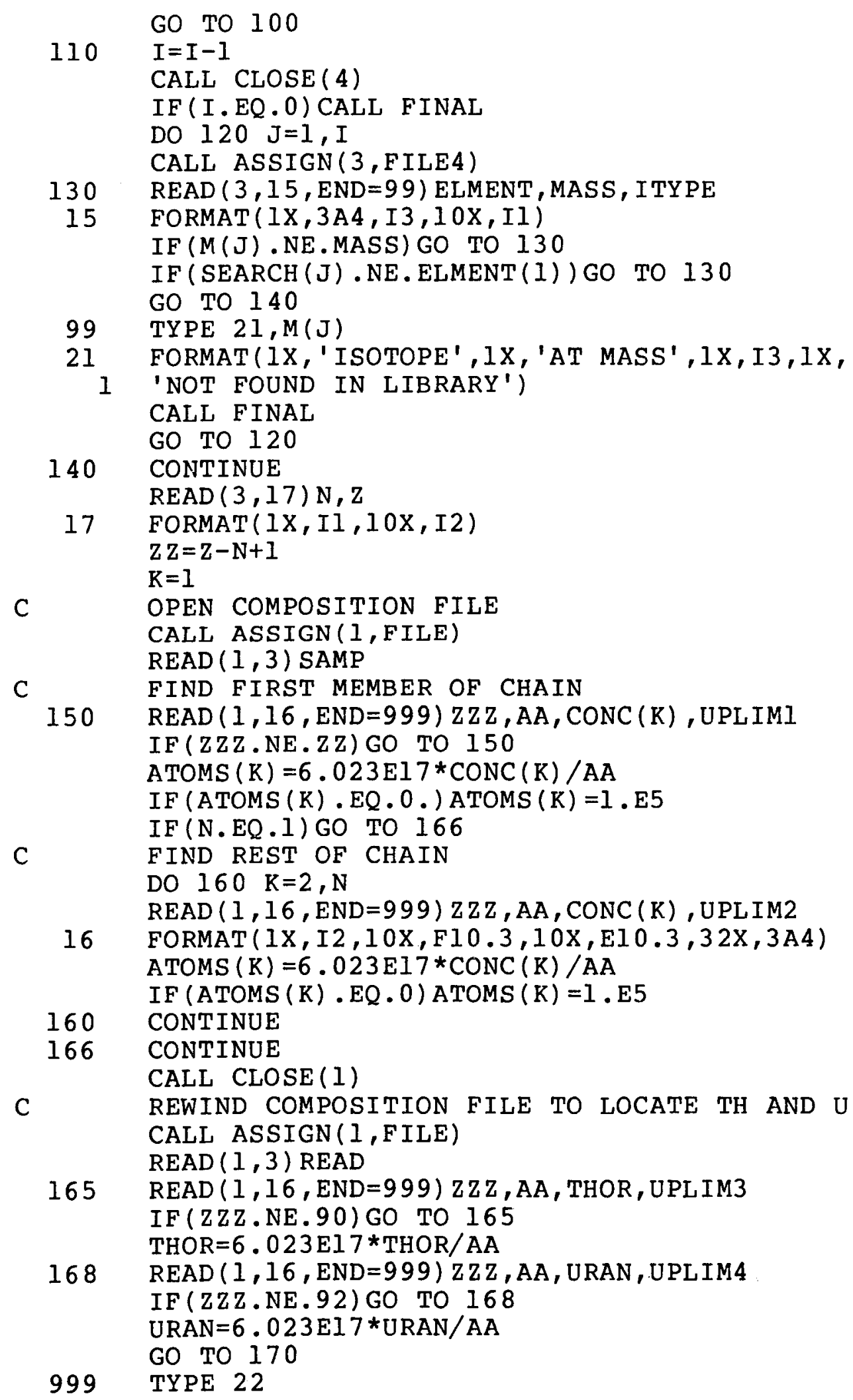

$165 \operatorname{READ}(1,16, \mathrm{END}=999) \mathrm{ZZZ}, \mathrm{AA}, \mathrm{THOR}, \mathrm{UPLIM} 3$ IF (ZZZ.NE.90)GO TO 165 
22 FORMAT( $1 X$, 'COMPOSITION FILE INCOMPLETE')

$$
\text { GO TO } 120
$$

170 CONTINUE

DO $180 \quad I I=1, N$

$\operatorname{READ}(3,23) \mathrm{JJ}$ (II), MM (II)

23 FORMAT (IX, II, 10X,I3)

DO $190 \mathrm{~L}=1, \mathrm{JJ}$ (II)

$\operatorname{READ}(3,24)$ ABUN ( L , I I) , FYIELD ( L , I I)

24 FORMAT $(1 \mathrm{X}, \mathrm{F} 7.4,10 \mathrm{X}, \mathrm{F} 7.4)$

$\operatorname{READ}(3,25)$ THALF ( L, II)

25 FORMAT (IX, E8.2)

$\operatorname{READ}(3,26) \operatorname{SIGMAT}(L, I I), \operatorname{SIGMAF}(L, I I), \operatorname{DEPLT}(\mathrm{L}, \mathrm{II}), \operatorname{DEPLF}(\mathrm{L}, \mathrm{II}$ )

26 FORMAT ( $1 \mathrm{X}, \mathrm{E} 8.2,3(10 \mathrm{X}, \mathrm{E} 8.2))$

190 CONTINUE

180 CONTINUE

IF (ITYPE. EQ.0) GO TO 400

$\operatorname{READ}(3,81)(\operatorname{SIGF}(\mathrm{LL}), \mathrm{LL}=1,10)$

$\operatorname{READ}(3,81)(\operatorname{SIGF}(L L), L L=11,20)$

$\operatorname{READ}(3,82)(\operatorname{SIGF}(L L), L L=21,29)$

400 CONTINUE

$\mathrm{KX}=\mathrm{N}-1$

$\mathrm{KY}=\mathrm{N}-2$

$\mathrm{MNM}=\mathrm{N}$

IF ( I TYPE . EQ . 0) IY $=\mathrm{N}$

IF ( ITYPE . EQ . I ) IY $=\mathrm{N}$

IF ( ITYPE . EQ . 2) IY $=\mathrm{N}-1$

IF ( ITYPE. EQ . 3) IY $=\mathrm{N}-1$

IF (ITYPE . EQ . 4) IY $=\mathrm{N}-2$

IF (ITYPE. EQ.0) $M N M=N$

IF ( ITYPE. EQ . 2) $M N M=N-1$

IF ( ITYPE . EQ . 3) $M N M=\mathrm{N}-1$

IF ( I TYPE . EQ . 4) MNM $=\mathrm{N}-2$

$J X=J J(M N M)$

IF ( I TYPE. EQ . I ) JX=JJ (N) -1

IF (ITYPE.EQ.0.OR. ITY PE.EQ.1) GO TO 156

IF (ITYPE. EQ.2.OR. ITY PE.EQ.3) GO TO 153

GO TO 154

$153 \quad M S=M M(K X)-1$

DO $155 \mathrm{LX}=1, \mathrm{JJ}(\mathrm{KX})$

$M S=M S+1$

IF (MASS . EQ . MS) L IX $=\mathrm{LX}$

155 CONTINUE

GO TO 156

$154 \quad M S=M M(K Y)-1$

DO $158 \mathrm{LX}=I, \mathrm{JJ}(\mathrm{KY})$

$M S=M S+1$

IF (MASS . EQ . MS) L IX $=\mathrm{LX}$

158 CONTINUE

156 CONTINUE

HFL IF $=$ THALF $(J X, I Y)$ 
WRITE $(2,27)$ ELMENT, MASS, HELIF

27 FORMAT ( $1 \mathrm{H} 1,3 \mathrm{~A} 4, \mathrm{I} 3,10 \mathrm{X}$, 'HALF-LIFE=' , $1 \mathrm{X}, 1 \mathrm{PE} 8.2,1 \mathrm{X}$, 'YEARS' ) WRITE $(2,270)$ CONC(IY), UPLIMI

270 FORMAT(IHO,'DIRECT CAPTURE TARGET ELEMENT CONCENTRATION

$\left.I=', F 9.2,1 \mathrm{X},{ }^{\prime} \mathrm{PPM} ', 10 \mathrm{X}, 3 \mathrm{~A} 4\right)$

IF (ITYPE . EQ . 0) WRITE $(2,280)$

IF ( ITYPE.EQ.1) WRITE $(2,281)$

IF (ITYPE.EQ.2) WRITE $(2,302) \operatorname{CONC}(\mathrm{N})$, UPL IM2

IF (ITYPE.EQ.3) WRITE (2,303) CONC (N) , UPL IM2

IF ( ITYPE.EQ . 4) WRITE $(2,304) \operatorname{CONC}(\mathrm{N})$, UPLIM2

280 FORMAT( 1 HO, 'N-GAMMA AND FISSION REACTIONS ONLY')

281 FORMAT(1HO, 'N-2N REACTION INCLUDED')

302 FORMAT(IHO, 'TARGET FOR N-P REACTION CONCENTRATION

$1=$ ', F9.2, IX, 'PPM ', 10X, 3A4)

303 FORMAT(IHO,' TARGET FOR N-D REACTION CONCENTRATION

$1=$ ', F9.2,1X, 'PPM', 10X, 3A4)

304 FORMAT(IHO, 'TARGET FOR N-ALPHA REACTION CONCENTRATION

$I=', F 9.2,1 \mathrm{X}$, 'PPM', 10X, 3A4)

WRITE $(2,20)$ COND

DO $200 \mathrm{JK}=1, \mathrm{JJ}(\mathrm{N})$

$200 \quad \mathrm{ISO}(\mathrm{JK})=\mathrm{MM}(\mathrm{N})+\mathrm{JK}-1$

WRITE $(2,29) \mathrm{Z}$

29 FORMAT(IHO, 4IX, 'BURNUP RATIOS FOR $\mathrm{Z}=$ ', I2)

$\operatorname{WRITE}(2,31)(\mathrm{ISO}(\mathrm{JK}), \mathrm{JK}=1, \mathrm{JJ}(\mathrm{N}))$

31 FORMAT (IX,'T(YEARS)', I0X,'ACTIVITY $(\mathrm{CI} / \mathrm{GM}) ', 9(5 \mathrm{X}, \mathrm{I3})$ )

CALL NCAP

TYPE 3111 , ELMENT, MASS

3111 FORMAT (1H0,' CALCULATION COMPLETE FOR ',3A4, I3)

CALL FINAL

120 CONTINUE

500 CONTINUE

CALL ASSIGN (1, FILE)

CALL COMBAS

CALL CLOSE ( 1 )

CALL CLOSE (2)

STOP 'DATA ON PRINT.ACT; *'

END 
SUBROUTINE NCAP

C ISOTOPE PRODUCTION AND DEPLETION SUBROUTINE FOR ACTIV

C

C

C

- $\mathrm{C}$

C

$\mathrm{C}$

C

VAX $11 / 780$ VERSION

INCLUDES FISSION PRODUCTS FROM U235-NATURAL ABUNDANCE

CALCULATES FISSION PRODUCTS FROM MULTIPLE NEUTRON

CAPTURE ON U238 AND TH232

FISSION YIELDS FOR U235 USED IN ALL CASES

INTEGRATION INCREMENT IS 3 DAYS

BETA DECAY IS GIVEN PRIORITY OVER BURNUP

DOUBLE PRECISION DELT, TAU $(9,9), T$

COMMON/CAPl/ATOMS $(9), \operatorname{ABUN}(9,9), \operatorname{FYIELD}(9,9), \operatorname{SigMAT}(9,9)$,

$1 \operatorname{SigmaF}(9,9), \operatorname{DEPLT}(9,9), \operatorname{DEPLF}(9,9), \operatorname{PHI}, \operatorname{CAdR}, \operatorname{ThALF}(9,9), \mathrm{N}, \mathrm{JJ}(9)$

2 , URAN, MM(10), TEMP, THOR

COMMON/CAP2/ACTIV, RATIO (9) ,IT, KK, ITYPE, SIGF (29) ,FLUX (29) ,JX, IY

DIMENSION START(9), $\operatorname{PROD}(10,10), M T(9)$

$\mathrm{BARN}=1 \cdot \mathrm{E}-24$

DELT $=3.15 E 5$

$\mathrm{KK}=\mathrm{J} J(\mathrm{~N})$

DO $50 \mathrm{~L}=1, \mathrm{JJ}(\mathrm{N})$

$\operatorname{START}(L)=\operatorname{ATOMS}(N) * \operatorname{ABUN}(L, N)$

50

$\operatorname{IF}(\operatorname{START}(L) . E Q .0.) \operatorname{START}(L)=1 . E 5$

$\mathrm{C}$

CONTINUE

COMPUTE TEMPERATURE CORRECTION TO $2200 \mathrm{M} / \mathrm{S}$ CROSS-SECTION

TCOR=SQRT $(.79 *(293 . /(273 .+$ TEMP $)))$

UF IVE $=$ URAN * . 0072

UEIGHT $=$ URAN* .993

UTHREE $=0$.

PLUT $=0$.

FAST $=$ PHI $/$ CADR

DO 150 II $=1, N$

DO $150 \mathrm{~L}=1, \mathrm{JJ}$ (II)

$\operatorname{TAU}(\mathrm{L}, \mathrm{II})=.69315 /(\mathrm{THALF}(\mathrm{L}, \mathrm{II}) * 3.15 \mathrm{E} 7)$

$\operatorname{PROD}(\mathrm{L}, \mathrm{II})=\operatorname{ATOMS}(\mathrm{II}) * \operatorname{ABUN}(\mathrm{L}, \mathrm{II})$

$\operatorname{SIGMAF}(L, I I)=\operatorname{SIGMAF}(L, I I) * B A R N$

$\operatorname{SIGMAT}(L, I I)=S I G M A T(L, I I) * B A R N * T C O R$

$\operatorname{DEPLT}(L, I I)=\operatorname{DEPLT}(L, I I) \star_{B A R N} * T C O R$

150

$\operatorname{DEPLF}(L, I I)=\operatorname{DEPLF}(L, I I) * B A R N$

CONTINUE

$\mathrm{FFAC}=0$.

IF (ITYPE.EQ.0) GO TO 152

C INTEGRATE FLUX TIMES CROSS-SECTION IN FAST REGION

DO 151 LLX $=1,29$

151 FFAC $=$ FFAC+SIGF (LLX) *BARN*FLUX (LLX)

152 CONTINUE

DO 300 IIT $=1,3000$

$I T=I I T$

DO $100 \quad I I=1, N$

C CALCULATE FISSION PRODUCT ADDITIONS TO FIRST MEMBERS

C OF EACH ROW

$\operatorname{PROD}(1, \mathrm{II})=\operatorname{PROD}(1, \mathrm{II})+\mathrm{UFIVE} *(\mathrm{PHI} * 5.8 \mathrm{E}-22$ *TCOR+ 
$1 \quad \mathrm{FAST} * 2.8 \mathrm{E}-22) * \mathrm{DELT} * \mathrm{FYIELD}(I, I I)$

$\operatorname{PROD}(1, \mathrm{II})=\mathrm{PROD}(1, \mathrm{II})+\mathrm{UTHREE} *(\mathrm{PHI} * 5.3 \mathrm{E}-22 * \mathrm{TCOR}+$

1 FAST*7.6E-22)*DELT*FYIELD (I,II)

$\operatorname{PROD}(1, \mathrm{II})=\mathrm{PROD}(1, \mathrm{II})+\mathrm{PLUT} *(\mathrm{PHI} * 7.4 \mathrm{E}-22 * \mathrm{TCOR}+$

1 FAST*3.E-22)*DELT*FYIELD $(I, I I)$

DO $200 \mathrm{~L}=2$, JJ (I I)

C CALCULATE NEUTRON CAPTURE ADDITIONS+FISSION PRODUCTS

C FOR REMAINING ISOTOPES

$L L=L-1$

$\operatorname{PROD}(L, I I)=\operatorname{PROD}(L, I I)+\operatorname{PROD}(L L, I I) *(P H I * \operatorname{SIGMAT}(L, I I)+$

$1 \quad$ FAST*SIGMAF ( L , II)) *DELT

PROD $(\mathrm{L}, \mathrm{II})=\mathrm{PROD}(\mathrm{L}, \mathrm{II})+\mathrm{UFIVE} *(\mathrm{PHI} * 5.8 \mathrm{E}-22$ *TCOR+

1 FAST*2.8E-22)*DELT*FYIELD (L, II)

PROD $(L, I I)=P R O D(L, I I)+U T H R E E *(P H I * 5.3 E-22 * T C O R+$

1 FAST*7.6E-22)*DELT*FYIELD $(L, I I)$

$\mathrm{PROD}(\mathrm{L}, \mathrm{II})=\mathrm{PROD}(\mathrm{L}, \mathrm{II})+\mathrm{PLUT} *(\mathrm{PHI} * 7.4 \mathrm{E}-22 * \mathrm{TCOR}+$

1 FAST*3.E-22)*DELT*FYIELD ( L , I I)

200 CONTINUE

C INCLUDE FAST FLUX CONTRIBUTION

$\operatorname{PROD}(J X, I Y)=P R O D(J X, I Y)+\operatorname{PROD}(J J(N), N)$ *FFAC DELT

DO $201 \mathrm{~L}=1, \mathrm{JJ}(\mathrm{II})$

$\mathrm{JT}=\mathrm{I} I+1$

IF (JT.GT.N) GO TO 202

$M T(I I)=M M(J T)-M M(I I)$

$\mathrm{KT}=\mathrm{L}-\mathrm{MT}(\mathrm{II})$

IF (KT.LT.I) GO TO 202

C CALCULATE BETA CHAIN CHANGES

$\operatorname{PROD}(K T, J T)=\operatorname{PROD}(K T, J T)+\operatorname{PROD}(L, I I)$ * $(1 .-\operatorname{DEXP}(-\mathrm{TAU}(L, I I)$ *DELT $))$

202 CONTINUE

C CALCULATE DECAY LOSSES

$\operatorname{PROD}(\mathrm{L}, \mathrm{II})=\mathrm{PROD}(\mathrm{L}, \mathrm{II}) * \operatorname{DEXP}\left(-\mathrm{TAU}(\mathrm{L}, \mathrm{II}){ }^{\mathrm{DELLT}}\right)$

C

CALCULATE BURNUP OF EACH ISOTOPE IN THE CHAIN

$\operatorname{PROD}(\mathrm{L}, \mathrm{II})=\operatorname{PROD}(\mathrm{L}, \mathrm{II})-\operatorname{PROD}(\mathrm{L}, \mathrm{II})$ * $(\mathrm{PHI}$ *DEPLT$(\mathrm{L}, \mathrm{II})+$

$\left.1 \quad \mathrm{FAST}^{*} \mathrm{DEPLF}(\mathrm{L}, \mathrm{II})\right) * \mathrm{DELT}$

201 CONTINUE

100 CONTINUE

DO $203 \mathrm{~L}=1, \mathrm{JJ}(\mathrm{N})$

$\operatorname{RATIO}(L)=\operatorname{PROD}(L, N) / \operatorname{START}(L)$

203 CONTINUE

$\mathrm{C}$

CONVERT ATOMS OF PRODUCT TO CURIES/GM.

$A C T I V=P R O D(J X, I Y) * T A U(J X, I Y) / 3.7 E I 0$

$\mathrm{C}$

CALCULATE PRODUCTION OF FISSIONABLE ISOTOPES

UTHREE =UTHREE+THOR * $(\mathrm{PHI}$ * $7.4 \mathrm{E}-24$ * TCOR+

1 FAST*8.5E-23)*DELT

PLUT $=$ PLUT+UEIGHT* $($ PHI * $2.7 \mathrm{E}-24$ *TCOR+FAST*2.7E-22)*DELT

$\mathrm{C}$

CALCULATE DEPLETION OF FISSIONABLE ISOTOPES

UTHREE=UTHREE-UTHREE* ( PHI *5.8E-22* TCOR+

1 FAST*9.0E-22)*DELT

PLUT $=$ PLUT-PLUT* $($ PHI * $1.0 \mathrm{E}-21$ *TCOR+FAST*5.E-22)*DELT

UFIVE=UFIVE-UFIVE* (PHI*6.8E-22*TCOR+FAST*4.2E-22) * 


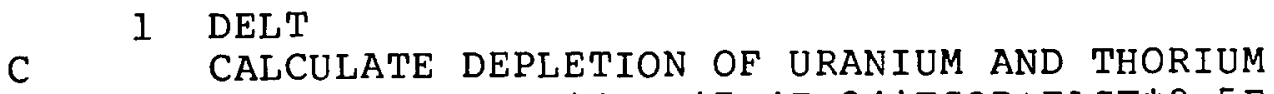

THOR $=$ THOR-THOR * $($ PHI * $7.4 \mathrm{E}-24$ *TCOR+FAST *8.5E-23)*DELT

UEIGHT=UEIGHT-UEIGHT* (PHI*2.7E-24*TCOR+FAST*

$12.7 \mathrm{E}-23) * \mathrm{DELT}$

CALL DMP

300 CONTINUE

WRITE $(2,16)$

16 FORMAT(1H0,5X, 'ACTIVITY(CI/GM)',10X,'YEARS AFTER SHUTDOWN') DO $500 \quad I K=1,7$

$I A=I K-I$

C CALCULATE DECAY OF PRODUCT AFTER SHUTDOWN OF REACTOR $\mathrm{T}=10 . * * \mathrm{IA} * 3.15 \mathrm{E} 7$

$\mathrm{ACTIV}=\mathrm{ACTIV}{ }^{*} \mathrm{DEXP}(-\mathrm{TAU}(\mathrm{JX}, \mathrm{IY}) * \mathrm{~T})$

$\mathrm{T}=\mathrm{T} / 3.15 \mathrm{E} 7$

WRITE $(2,17)$ ACTIV, T

17 FORMAT(IIX, IPEI0.2, 20X, IPE10.2)

500 CONTINUE

RETURN

END 


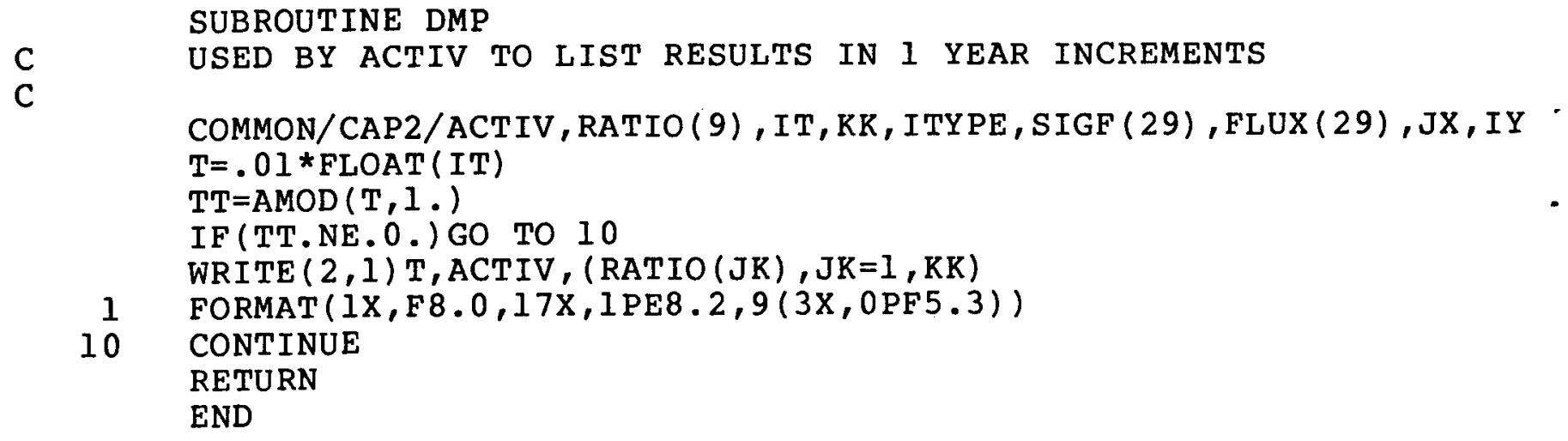


SUBROUTINE FINAL

C USED BY ACTIV TO CALCULATE TIME ELAPSED FOR EACH ISOTOPE

COMMON/CAPI0/TI

CALL CLOSE (3)

CALL CLOSE ( 1 )

DELTA $=$ SECNDS ( Tl)

DELTA $=$ DELTA $/ 60$.

TYPE 40 , DELTA

40 FORMAT ( $1 \mathrm{X}$, 'ELAPSED TIME ='F8.2,1X, 'MINUTES')

RETURN

END 


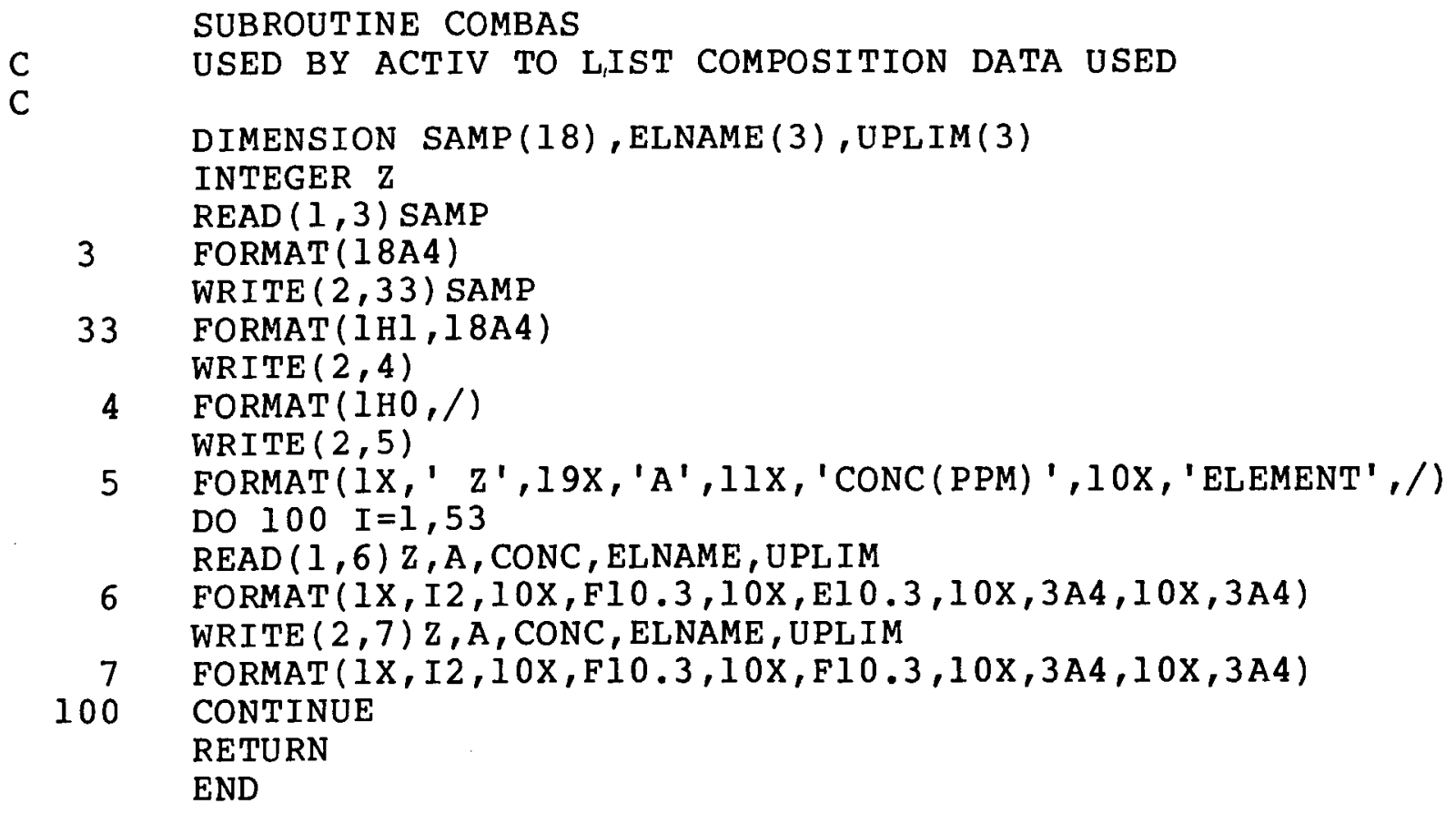




\section{APPENDIX B}

PROGRAM LISTINGS 


\section{DISTRIBUTION}

No. of

Copies

OFFSITE

U.S. Nuclear Regulatory Commission

Division of Technical

Information and Document Control

7920 Norfolk Avenue

Bethesda, MD 20014

20 C. Feldman

Division of Engineering Technology

Office of Nuclear Regulatory Research

U.S. Nuclear Regulatory Commission

Washington, D.C. 20555

2 K. G. Steyer

Division of Engineering Technology

Office of Nuclear Regulatory Research

U.S. Nuclear Regulatory Commission

Washington, D.C. 20555
No. of

Copies

L. A. Rancitelli

Battelle Columbus Laboratories

West Jefferson Laboratories

$505 \mathrm{King}$ Avenue

Columbus, $\mathrm{OH} 43201$

ONSITE

26 Pacific Northwest Laboratory

K. H. Abel

D. W. Dragnich

5 J. C. Evans

J. S. Fruchter

W. A. Glass

P. C. Hays

E. A. Lepel

R. W. Perkins

D. E. Robertson

R. W. Sanders

R. I. Smith

C. W. Thomas

C. M. Unruh

N. A. Wogman

Publishing Coordination (2)

Technical Information (5) 


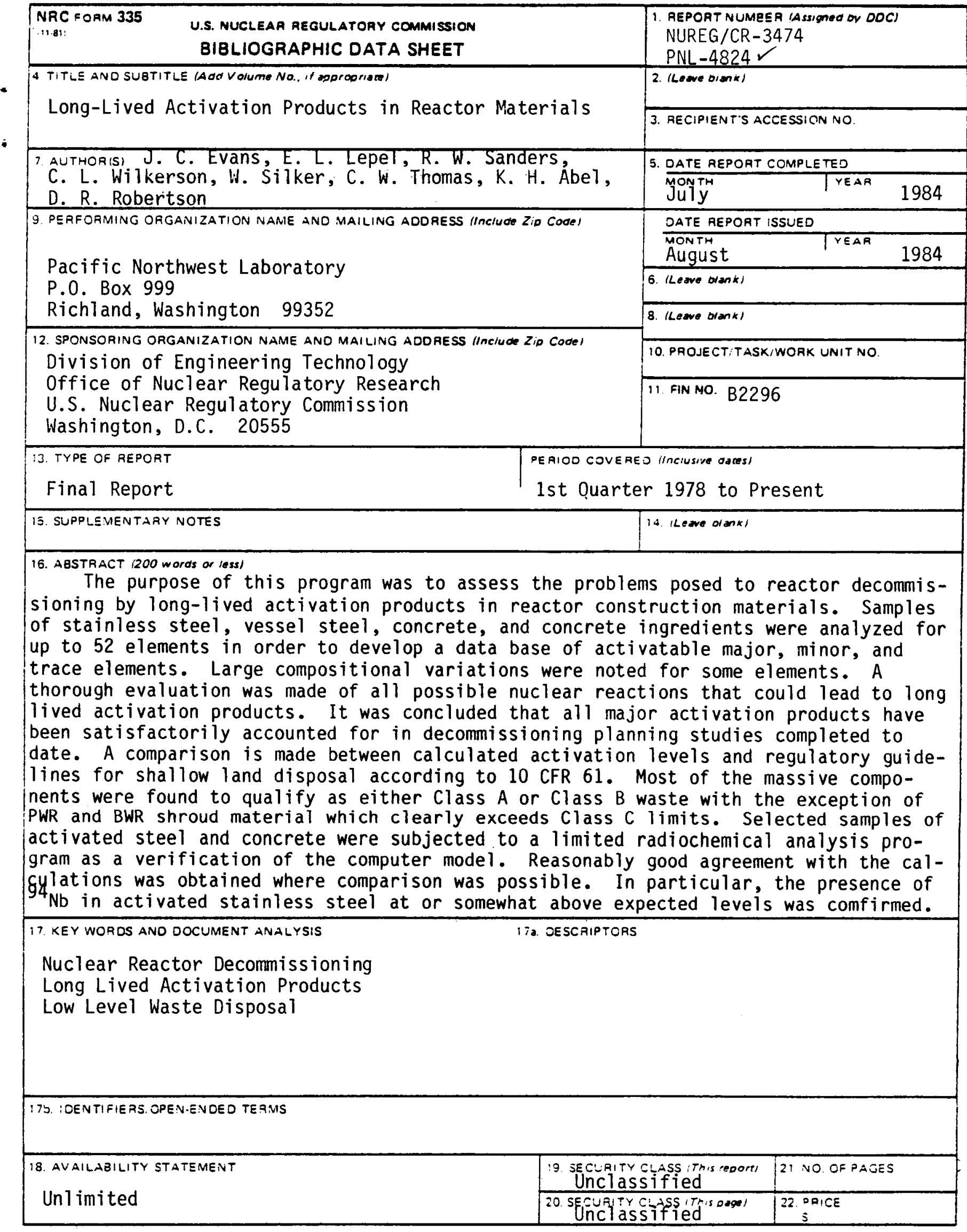

VAC FOAM 335 111.811 


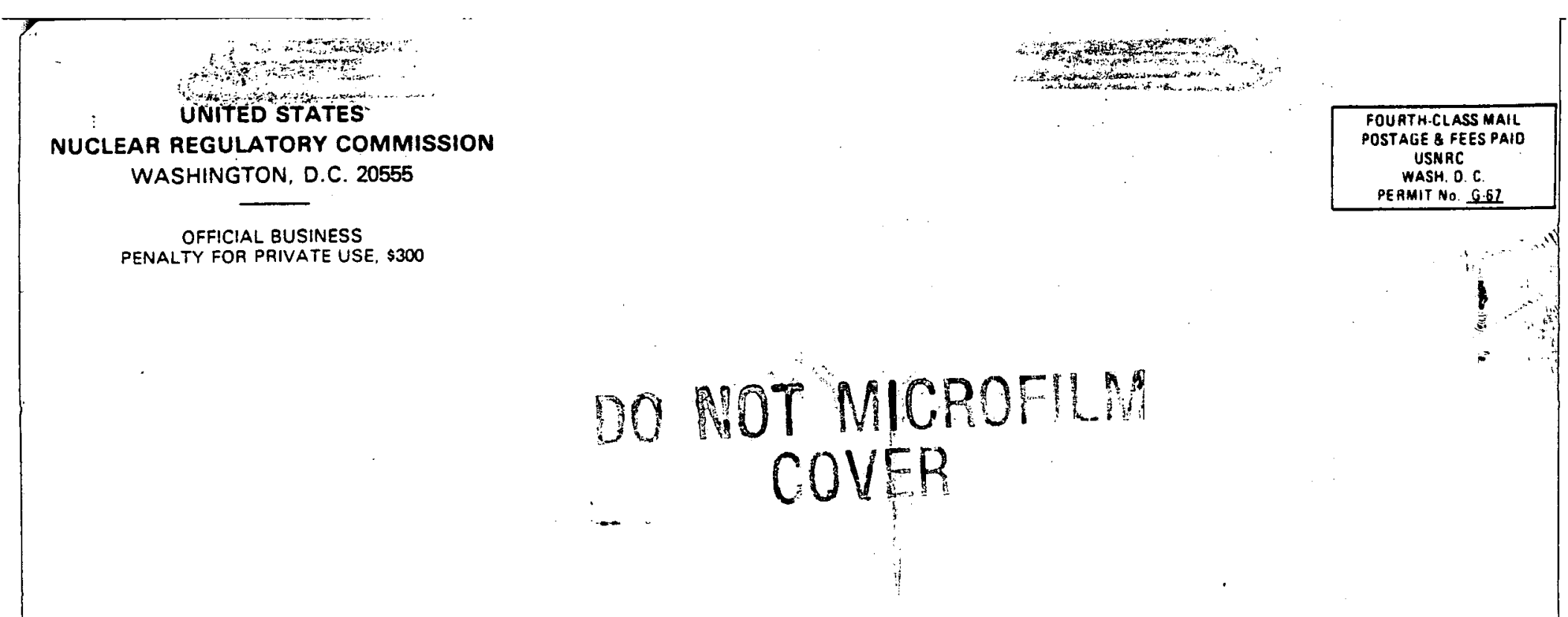

